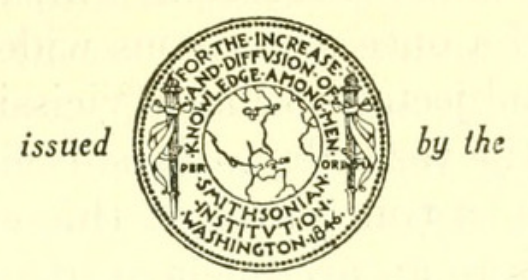

SMITHSONIAN INSTITUTION

U.S. NATIONAL MUSEUM

Washington : 1938

No. 3039

\title{
THE CUBAN OPERCULATE LAND SHELLS OF THE SUBFAMILY CHONDROPOMINAE
}

\author{
By Carlos de la Torre and Paul Bartsch
}

\section{INTRODUCTION}

IN ALL the world there is no place of equivalent area that has a greater number of species and races of land shells than the Island of Cuba. It is a veritable paradise for the lover of mollusks, for we find not only a numerical preponderance but also beauty of outline and coloration rivaling the famas of the Philippine and Hawaiian Islands.

The interesting features presented by this fauna are not restricted in appeal to the systematic zoologists-taxonomists-for here the student of genetics and heredity also will find a veritable laboratory teeming with an endless number of problems inviting solution.

In Pinar del Rio Province, in western Cuba, the Organ Mountains, because they are broken up into isolated blocks and by the even greater cutting up of the lateral folds to the north and south, now largely represented by the series of mogotes-hills-of varying size into which the teeth of time have cut them, show splendidly in their faunas the effects of isolation and inbreeding, resulting in an almost endless array of races, each confined to a limestone cliff, which may vary in size from a barn door to miles in extent.

To such restricted habitats most of the members of the subfamily Chondropominae are more firmly wedded today than they would be if they occupied equally distant islands, from which they might be carried by currents or waves to neighboring shores, for grassy intervals present a greater barrier to these calciphil dwellers than would the open sea. As we see it, there are only two agencies at present that might serve as carriers from place to place, wind and birds, 
neither of which would seem to be effective in the transportation of members of the groups under discussion, which we believe are largely segregation products of a once continuous widely spread fauna.

Western Cuba was subjected to many vicissitudes during Tertiary times and even during the yesterdays of the Pleistocene, for vacillating ocean levels from time to time changed this end of the island from a continuous land mass to an archipelago of islands, eliminating the lowland faunas and confining the survivors to the influence of their restricted island habitats. All of which presents a fascinating history that our studies are slowly revealing.

We shall have occasion to call attention to some of these problems under the diverse groups here presented and discussed.

These Cuban mollusks have received the attention of many of the naturalists who have visited the "Pearl of the Antilles," or discussed its faunas from the days of Humboldt and Bonpland to date. Their listing displays such names as Sagra, d'Orbigny, Pfeiffer, Gundlach, Otto, Wright, Poey, Gould, Arango, Morelet, Sagebien, Henderson, Simpson, Clapp, Pilsbry, Barbour, Miner, Welch, Lowe, Allen, Clench, Rehder, Hermano León, Father Roca, and de la Torre and his students, among them especially Rodriguez, Aguayo, Ramsden, Bermudez, Portuondo, Moreno, and Jaume. To these should also be added a host of de la Torre's friends, too numerous to mention, who have lent a hand in this enterprise, as well as many field men commissioned from time to time by him to explore specific regions in need of investigation.

Looking over the field as a whole we may say that the major discoveries in our field fall to the credit of de la Torre, Gundlach, Pfeiffer, Sagra, Poey, Henderson, and Bartsch, the efforts of Torre, Henderson, and Bartsch being directed toward the specific exploration and elucidation of the island fauna.

The present paper is a resumption of the studies by Henderson and Bartsch published in 1920, "A Classification of the American Operculate Land Mollusks of the Family Annulariidae." 1 Mr. Henderson's untimely death interrupted this effort, which is now resumed by his devoted friends.

\section{Subfamily Chondropominae Henderson and Bartsch}

1920. Chondropominae Henderson and Bartsch, Proc. U. S. Nat. Mus., vol. 58, p. 59.

Annularid mollusks whose shell ranges in form from turbinate to elongate-conic. The axial sculpture may consist of strong ribs or range from these to slender, almost lamellar riblets, or it may be re-

${ }^{1}$ Proc. U. S. Nat. Mus., vol. 58, pp. 49-82, 1920. 
duced to incremental lines. There is also a wide range of strength in the development of the spiral sculpture, which may be confined to the umbilicus or may cover the entire shell. Breathing devices are present in some groups and absent in others. The chief character of the subfamily, however, is found in the operculum, which consists of a thin, simple chondroid basal plate of several whorls, the outer edge of which may be faintly upturned to form a very fragile, low, slender lamella, suggesting the starting point of the subfamily Adamsiellinae. This is, however, usually soon brushed away, leaving the operculum as a plain plate. The operculum has a deposit of fine calcareous granules which may be very slight or fairly strong, depending upon the species in question.

\section{Type genus.-Chondropoma Pfeiffer.}

ARTIFICIAL KEY TO GENERA AND SUBGENERA OF SUBFAMILY CHONDROPOMINAE

Breathing device absent.

Shell turbinate

Chondropometes (p. 196)

Shell not turbinate.

Shell turreted. Turripoma (p. 251)

Shell not turreted.

Shell elongate-conic.

Hendersonida (p. 234)

Shell not elongate-conic.

Shell very broadly ovate

Orientipoma (p. 390)

Shell not very broadly ovate.

Shell ovate.

Junctions of axial ribs and spiral threads forming short cusps.

Axial ribs gathered into tufts at the summit. Scobinapoma (p. 237) Axial ribs not gathered into tufts at the summit.

Outer peristome broadly expanded_. Chondropomartes (p. 383)

Outer peristome not broadly ex-

panded

Chondropomisca (p. 375)

Junctions of axial ribs and spiral threads not forming short cusps. Axial ribs gathered into tufts at the summit.

Axial ribs threadlike; sculpture re-

ticulated ................... C

Axial ribs sublamellar; sculpture

vertebrated ................. Chondropomodes (p. 361)

Axial ribs not gathered into tufts at the

summit

Chondropoma (p. 322)

Breathing device present.

Breathing device a slit in the parietal wall

Chondrothyrium (p. 395)

Breathing device not a slit but a puncture.

Shell turbinate.

Chondrothyroma (p. 212)

Shell not turbinate.

Shell turreted.

Umbilicus open.

Shell brightly colored................... Hendersonina (p. 233)

Shell not brightly colored.................... Turrithyra (p. 240)

Umbilicus closed ...................... Turrithyretes (p. 240) 
Breathing device present-Continued.

Breathing device not a slit but a puncture-Continued.

Shell not turbinate-Continued.

Shell not turreted.

Shell ovate.

Umbilicus open.

Last whorl solute.

Hendersonoma (p. 252)

Last whorl not solute.

Inner lip of outer peristome with a plication_. Plicathyra (p. 263)

Inner lip of outer peristome without a plication

Umbilicus closed.

Chondrothyra (p. 252)

Inner lip of outer peristome cut

Chondrothyretes (p. 269)

Inner lip of outer peristome not cut but with

a deep pit

Foveothyra (p. 265)

Shell not ovate.

Shell subglobose.

Umbilicus open _..................... Plicathyrella (p. 306)

Umbilicus closed ................... Chondrothyrella (p. 306)

\section{Genus CHONDROPOMETES Henderson and Bartsch}

1920. Chondropometes Henderson and Bartsch, Proc. U. S. Nat. Mus., vol. 58, p. 60 .

Shell of turbinate form, openly umbilicated, marked by axial and spiral threads. Lip simple or double. Breathing pore present or absent. Operculum subcircular, multispiral with the inner part of the whorls covered with a heavy calcareous calluslike deposit.

Type: Chondropometes (Chondropometes) vignatense (Wright) Pfeiffer.

In $1920^{2}$ Henderson and Bartsch created the subgenus Chondropometes, making it a subdivision of Chondropoma. They likewise founded the subgenus Chondrothyroma, ${ }^{2}$ placing this under their genus Chondrothyra. The finding of specimens of Chondropometes (Chondrothyroma) scoputomum perplexum and $C$. $(C$.) magnum magnum without breathing pore, leads us to make the following realignment, which we believe to be phylogenetically and zoogeographically more sound.

\section{IEY TO THE SUBGENERA OF GENUS CHONDROPOMETES}

Breathing pore present Chondrothyroma (p. 212)

Breathing pore absent Chondropometes (p. 196)

Subgenus Chondropometes Henderson and Bartsch

1920. Chondropometes Henderson and Bartsch, Proc. U. S. Nat. Mus., vol. 58, p. 60 .

Chondropometes without breathing pore.

Type: Chondropometes (Chondropometes) vignalense (Wright) Pfeiffer. 
KEY TO THE SPECIES OF SUBGENUS CHONDROPOMETES

Peristome broadly expanded latilabre

Peristome not broadly expanded.

Peristome only moderately expanded torrei Peristome not moderately expanded.

Peristome only very slightly expanded. vignalense

CHONDROPOMETES (CHONDROPOMETES) LATILABRE (Orbigny)

Plate 8, Fig. 1

1845. Cyclostoma latilabris ORBIGNy, in Sagra's Histoire physique, politique et naturelle de l' île de Cuba, vol. 1, pp. 255-256, pl. 21, fig. 12.

Shell turbinate, flesh-colored, pale horn colored, pale brown, or sometimes rather dark purplish brown; in the dark phase the color becomes intensified on the last whorl behind the peristome. Nuclear whorls 2 , forming a somewhat truncated apex, the early portions minutely microscopically granulose, the last portion of the last turn with indications of closely approximated feeble axial threads. Postnuclear whorls inflated, strongly rounded, marked by slender sublamellar, decidedly retractively curved axial riblets; those on the last whorl being a little more distantly spaced than the rest. In addition to this, the early whorls show slender spiral threads, which become enfeebled on the later turns but are present even on the last portion of the last turn. The junction of these spiral threads with the axial riblets renders these somewhat sinuous and somewhat thickened at their junction. Periphery of the last whorl well rounded. Base strongly inflated, well rounded, openly umbilicated, marked by the continuations of the axial riblets and rather feeble spiral threads. This stronger spiral sculpture extends to the outer limit of the umbilicus. The last whorl is solute for about one-fifteenth of a turn. Aperture somewhat irregularly broadly ovate; peristome double, the inner slightly expanded and thickened, the outer very broadly expanded and reflected, not all in one plane, but somewhat wavy. The expanded portion is almost of the same width all the way around. It is adnate to the preceding turn on the parietal wall, while the reflected portion projects over a little more than half the umbilicus on the columellar border. The peristome is yellowish white, while the inside of the aperture is pale brown. Operculum paucispiral with subcentral nucleus, covered with a thin granular deposit excepting a broad border at the edge.

The specimens described and figured, U.S.N.M. no. 354923, are part of a lot of 62 that we collected on the Tomas Barrera Expedition in 1914, when we found this species to extend from San Juan de Sagua at the western end of Pan de Guajaibon to the middle of its northern slope. 


\section{CHONDROPOMETES (CHONDROPOMETES) TORREI Bartsch}

Shell rather large, turbinate, thin, semitranslucent, openly umbilicate, varying in color from pale buff through yellow to orange-buff to brown, unicolor or with a dark vertical band behind the peristome, with or without spiral bands. Peristome expanded and reflected, about half as wide as that of $C$. $(C$.) latilabre (d'Orbigny). Nuclear whorls about 2 , in perfect conformity in their coiling with the postnuclear turns. The first is thin, translucent, appearing finely granulose under high magnification; the last marked by feeble, somewhat retractively slanting, closely spaced, incremental lines. Postnuclear whorls inflated, well rounded, marked by very regular, retractively slanting, sublamel'ar axial riblets, which are a little less wide than the spaces that separate them. In addition to these, there are narrow varicial streaks at more or less regular intervals. These may be lighter or darker than the general tone of the shell. They are the result of the approximation of two or more axial riblets. The spiral sculpture consists of quite regularly spaced threads which are separated by spaces a little wider than the threads. These threads at their junction with the axial ribs render these slightly wavy, and under high magnification give a somewhat serrated aspect to them. The spiral sculpture is very variable in strength, ranging from obsolete to quite pronounced. Suture well impressed; periphery inflated, well rounded. Base inflated, well rounded, marked like the spire. Axial riblets extend over the wall of the umbilicus, becoming usually a little stronger within. The spiral sculpture within the umbilicus consists of much stronger threads than those on the spire. The last whorl in adult shells is solute for some little distance. The outside of the parietal wall here shows the continuation of the axial riblets. Aperture subcircular, slightly angulated at the posterior angle. Operculum thin, multispiral, horny, with a fine, granulose, calluslike deposit, which is heaviest on the inner margin and thins out outwardly, vanishing a little beyond the middle of the turn. This deposit is laid down in more or less of a corrugated pattern.

The animal of $C$. (C.) torrei minaense has the sides smoky gray. The top of the forehead and back are darker; the tips of the snout are pale buff and the tentacles bright orange, slightly paler at the slightly expanded tip, sole of the foot pale smoky gray. Sole of foot medially longitudinally cleft; locomotion of the two sides alternate. When at rest the animal suspends itself by a mucous thread. That of $C$. (C.) t. collumelare has the dorsal part of the animal smoky gray; sides paler. Sole of foot flesh-color, with a smoky suffusion. Tentacles orange-red, with the expanded distal portion dark smoke gray. Snout smoke gray, with the tip flesh-colored with a smoky suffusion. 
This species is known from the Sierra San Andrés, the Sierra Guacamayas, and the Sierra Galalón, also from certain mogotes south and west of these limestone blocks. All the members are cave or cavity dwellers and very restricted in their distribution for that reason. They are nocturnal in their habits and suspend themselves in the daytime by a mucous thread from the roof of the cavity that they occupy. In these isolated places characters peculiar to each have been developed, and to these we are assigning subspecific rank. Sixteen of these subspecies are known at present. The several outstanding characteristics of each are taken cognizance of in the following key and the brief descriptions that follow. The descriptions are listed in westeastward geographic order.

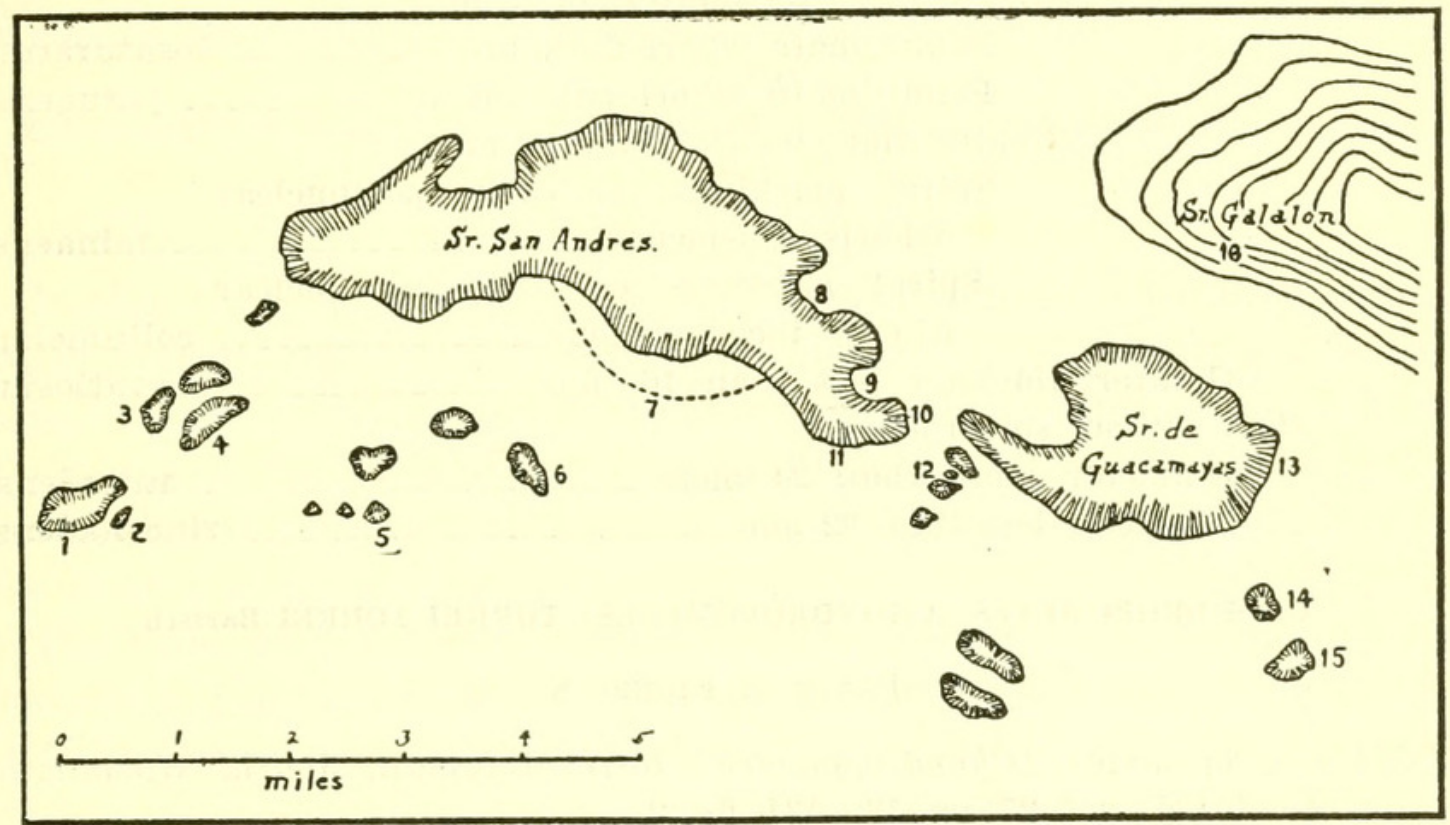

FIgure 71.-Distribution of the subspecies of Chondropometes (Chondropometes) torrei:

(1) minaense; (2) rinconadense; (3) jaguaense; (4) antoniense; (5) antonitense; (6) torrei; (7) cingulatum; (8) iosaturatum; (9) collumelare; (10) luteilabre; (11) flammilabre; (12) affine; (13) gratiosum; (14) flavidum; (15) pallidulum; (16) alveare.

Here also it should be stated that while we usually refer only to the type, the conclusions expressed in our statements are not based on this specimen only but are usually founded on a considerable series of individuals in the collection of the United States National Museum and that of Dr. Carlos de la Torre.

Distribution of the subspecies of $C$. (C.) torrei is shown in figure 71.

\section{KEY TO THE SUBSPECIES OF CHONDROPOMETES (CHONDROPOMETES) TORREI}

Peristome red.

Shell without spiral color bands torrei

Shell with interrupted spiral color bands.

Interrupted spiral bands rather strong antonitense Interrupted spiral bands rather feeble flammilabre 
Peristome yellow or flesh-color.

Shell with spiral bands.

Spiral bands conspicuous.

Dark axial zone behind peristome very decided.

Peristome orange cingulatum

Peristome flesh-color affine

Dark axial zone behind peristome not decided.

Peristome yellow. flavidum

Peristome flesh-color pallidulum

Spiral bands not conspicuous.

Greater diameter more than $20 \mathrm{~mm}$.

General color clouded, pale.

Spiral banding confined to periphery alveare

Spiral banding not confined to periphery luteilabre General color not clouded, dark.

Greater diameter more than $23 \mathrm{~mm}$.

Penultimate whorl dark brown iosaturatum

Penultimate whorl pale brown jaguaense Greater diameter less than $22 \mathrm{~mm}$.

Spiral markings on early postnuclear whorls conspicuous minaense

Spiral markings on early postnuclear whorls inconspicuous. collumelare

Greater diameter less than $16 \mathrm{~mm}$ gratiosum Shell without spiral bands.

Diameter more than $24 \mathrm{~mm}$ antoniense

Diameter less than $22 \mathrm{~mm}$ rinconadense

\title{
CHONDROPOMETES (CHONDROPOMETES) TORREI TORREI Bartsch
}

\author{
Plate 9, Figure 8
}

1937. Chondropometes (Chondropometes) torrei BARTsCH, Journ. Washington Acad. Sci., vol. 27, pp. 130-131, fig. 2.

This is the most brilliantly colored of the subspecies. It is characterized by its orange-buff color, with darker orange varicial streaks and flame-colored peristome. It comes from Abra de Bejarano, Mogote Canalete, south of the Sierra San Andrés.

The type, U.S.N.M. no. 428794 , is a complete specimen having 6 whorls, and measures: Length, $23.0 \mathrm{~mm}$; greater diameter, $22.3 \mathrm{~mm}$; lesser diameter, $15.9 \mathrm{~mm}$.

\section{CHONDROPOMETES (CHONDROPOMETES) TORREI ANTONITENSE, new subspecies}

\section{Plate 8, Figure 9}

Shell small, pale iodine brown, with flame-colored peristome, conspicuously banded with continuous brown bands of deeper shade than the general tone of the shell. This small race comes from Hoyo Corto de San Antonio.

The type, U.S.N.M. no. 428798 , has 4.9 whorls remaining and measures: Length, $19.7 \mathrm{~mm}$; greater diameter, $18.4 \mathrm{~mm}$; lesser diameter, $13.8 \mathrm{~mm}$. 
CHONDROPOMETES (CHONDROPOMETES) TORREI FLAMMILABRE, new subspecies

Plate 8, Figure 6

Shell of medium size, dark iodine brown, with slightly paler varicial streaks and spiral bands, which are of a slightly deeper shade than the general coloration but quite inconspicuous. The peristome is flame-color.

The specimens before us were collected at Pico Grande, Sierra de San Andrés. It extends west to Zumbido, in the same range.

The type, U.S.N.M. no. 428796, has 3.5 whorls remaining and measures: Length, $21.5 \mathrm{~mm}$; greater diameter, $19.9 \mathrm{~mm}$; lesser diameter, $15.3 \mathrm{~mm}$.

This subspecies suggests $C$. (C.) torrei iosaturatum, from which it can be distinguished at once by its brilliantly colored peristome.

CHONDROPOMETES (CHONDROPOMETES) TORREI CINGULATUM, new subspecies

Plate 9, Figure 4

In this race the shell is of flesh-colored ground coloring, conspicuously marked by broad spiral bands of brown. There is also a very broad dark purplish-brown area immediately behind the peristome. The latter is buff. The type comes from the Ensenada de la Ayua, but the race extends east from there to the Ensenada Zumbido, in the Sierra de San Andrés.

The type, U.S.N.M. no. 428793, has almost 4 whorls remaining and measures: Length, $22.4 \mathrm{~mm}$; greater diameter, $28.8 \mathrm{~mm}$; lesser diameter, $14.7 \mathrm{~mm}$.

CHONDROPOMETES (CHONDROPOMETES) TORREI AFFINE, new subspecies

Plate 10, Figure 1

Shell similar to $C$. $(C$.) torrei cingulatum but smaller and paler, having the axial dark zone behind the peristome even more strongly expressed and the peristome flesh-color, not yellow.

This race was collected by Natenson on the second mogote south of the west end of the Sierra Guacamayas.

The type, U.S.N.M. no. 468920, is an almost complete specimen, having lost about half of the first turn; the 4.9 whorls remaining measure: Length, $21.5 \mathrm{~mm}$; greater diameter, $19.0 \mathrm{~mm}$; lesser diameter, $15.1 \mathrm{~mm}$.

CHONDROPOMETES. (CHONDROPOMETES) TORREI FLAVIDUM, new subspecies

Plate 9, Figure 6

Shell similar to $C$. (C.) torrei affine but with the dark axial zone behind the peristome very faintly expressed and the peristome yellow. 
This race was collected by Natenson on the mogote between the southeast end of the Sierra Guacamayas and Mogote Largo, to the south of this.

The type, U.S.N.M. no. 468922, is an almost complete specimen, having lost probably the first half turn. The 5.1 whorls remaining measure: Length, $22.0 \mathrm{~mm}$; greater diameter, $20.2 \mathrm{~mm}$; lesser diameter, $15.5 \mathrm{~mm}$.

CHONDROPOMETES (CHONDROPOMETES) TORREI PALLIDULUM, new subspecies

Plate 9, Figure 1

Shell similar to $C$. $(C$.) torrei flavidum but with less yellow in the general coloration and with the peristome flesh-color. The dark axial zone behind the peristome is poorly expressed.

This race was collected by Natenson on Mogote Largo, which is the second mogote southwest of Pico Chico in the Sierra Guacamayas.

The type, U.S.N.M. no. 468924 , is a complete specimen, having 6.0 whorls and measuring: Length, $23.1 \mathrm{~mm}$; greater diameter, $20.8 \mathrm{~mm}$; lesser diameter, $15.5 \mathrm{~mm}$.

CHONDROPOMETES (CHONDROPOMETES) TORREI ALVEARE, new subspecies

Plate 10, Figure 2

This subspecies closely resembles $C$. $(C$.) torrei luteilabre but is paler than that race and has the spiral banding practically always confined to the peripheral region, where it usually constitutes an inconspicuous interrupted spiral band. Occasionally there is a mere indication of additional bands, but the shell never bears as many bands as in $C$. $(C$.) torrei luteilabre.

The type, U.S.N.M. no. 468756, comes from Mogote Colmena de Piedra, which is the southwestern part of the Sierra Galalón. This is a complete specimen having 6.0 whorls and measuring: Length, $23.2 \mathrm{~mm}$; greater diameter, $21.8 \mathrm{~mm}$; lesser diameter, $15.8 \mathrm{~mm}$.

CHONDROPOMETES (CHONDROPOMETES) TORREI LUTEILABRE, new subspecies

Plate 10, Figure 6

Shell small, very pale yellow with a broad axial area of dark iodine purple a little distance behind the peristome. The shell also has pale bands of brown, which extend upon the peristome, which is pale yellow.

This subspecies comes from the Puerto del San Andrés, that is, the extreme eastern end of the Sierra. 
The type, U.S.N.M. no. 428797 , has 3.8 whorls remaining and measures: Length, $18.9 \mathrm{~mm}$; greater diameter, $19.1 \mathrm{~mm}$; lesser diameter, $15.4 \mathrm{~mm}$.

CHONDROPOMETES (CHONDROPOMETES) TORREI IOSATURATUM, nEw subspecies

\section{Plate 10, Figure 8}

Shell rather large, iodine brown, more intense immediately behind the peristome, which is yellow. Inconspicuous bands of darker brown are also present, which are strongly marked on the inner half of the back of the expanded peristome.

The specimens before us were collected at Sitio de la Sierra de San Andrés by Father Roca and Bermudez.

The type, U.S.N.M. no. 367735, has 4 whorls remaining and measures: Length, $24.9 \mathrm{~mm}$; greater diameter, $23.5 \mathrm{~mm}$; lesser diameter, $17.2 \mathrm{~mm}$.

The large size and paler peristome distinguish this from $C .(C$. torrei flammilabre.

CHONDROPOMETES (CHONDROPOMETES) TORREI JAGUAENSE, new subspecies

\section{Plate 9, Figure 5}

Very similar to $C$. $(C$.) torrei luteilabre but larger and with much finer and more closely spaced axial sculpture.

The type, U.S.N.M. no. 468720, comes from La Jagua, Consolación del Norte. It has 3.7 whorls remaining and measures: Length, 22.3 $\mathrm{mm}$; greater diameter, $23.4 \mathrm{~mm}$; lesser diameter, $15.3 \mathrm{~mm}$.

CHONDROPOMETES (CHONDROPOMETES) TORREI MINAENSE, new subspecies

\section{Plate 9 , Figure 7}

This subspecies ranges from pale brown to pale iodine color, with the peristome always pale yellow. In the darker forms the area behind the peristome is of deeper coloration than the rest. The nuclear whorls are pale and the early postnuclear whorls dark, while the penultimate whorl is paler and the last turn behind the aperture again matches the early postnuclear whorls. Inconspicuous spiral bands are present.

This race comes from Mogote Mina.

The type, U.S.N.M. no. 354917, is a complete specimen, having 6 whorls and measuring: Length, $23.3 \mathrm{~mm}$; greater diameter, $20.6 \mathrm{~mm}$; lesser diameter, $16.0 \mathrm{~mm}$. 
CHONDROPOMETES (CHONDROPOMETES) TORREI COLLUMELARE, new subspecies

Plate 9, Figure 3

This shell resembles $C$. $(C$.) torrei minaense but is more strongly spirally banded, the bands usually also being broader, sometimes being very wide. It differs from this markedly by its much smaller size. From $C .(C$.) torrei iosaturatum it is readily distinguished also by its smaller size and much stronger banding.

The type, U.S.N.M. no. 468833, was collected by Collmillo de la Vieja on the northeast side of the Sierra Guacamayas. It is an almost complete specimen having 5.0 whorls remaining and measuring: Length, $21.1 \mathrm{~mm}$; greater diameter, $19.3 \mathrm{~mm}$; lesser diameter, $14.8 \mathrm{~mm}$.

CHONDROPOMETES (CHONDROPOMETES) TORREI GRATIOSUM, new subspecies

\section{Plate 8, Figure 3}

This race in coloring resembles $C .(C$.) torrei tuteilabre, from which its diminutive size at once distinguishes it. It is the smallest known subspecies of $C$. (C.) torrei.

The type, U.S.N.M. no. 468719 , is a complete specimen having 5.4 whorls and measuring: Length, $16.0 \mathrm{~mm}$; greater diameter, $15.0 \mathrm{~mm}$; lesser diameter, $11.5 \mathrm{~mm}$. It comes from Pinalito in the southwestern part of the Sierra de Galalón.

CHONDROPOMETES (CHONDROPOMETES) TORREI ANTONIENSE, new subspecies

Plate 10, Figure 7

Shell large, very pale yellow, with the parietal wall of the umbilicus buff, which is also the color of the peristome at this place.

This large subspecies comes from Mogote de la Jagua.

The type, U.S.N.M. no. 354919 , has 3.7 whorls remaining and measures: Length, $24.3 \mathrm{~mm}$; greater diameter, $24.7 \mathrm{~mm}$; lesser diameter, $17.8 \mathrm{~mm}$.

CHONDROPOMETES (CHONDROPOMETES) TORREI RINCONADENSE, new subspecies

Plate 9, Figure 2

This race, which comes from the small mogote known as Rinconada, close by Mogote de la Mina, is pale yellow with almost white lip.

The type, U.S.N.M. no. 468846, a complete specimen, has 5.6 whorls and measures: Length, $22.5 \mathrm{~mm}$; greater diameter, $20.3 \mathrm{~mm}$; lesser diameter, $15.4 \mathrm{~mm}$. 
CHONDROPOMETES (CHONDROPOMETES) VIGNALENSE (Wright) Pfeiffer

Shell rather large, turbinate, thin, semitranslucent, openly umbilicated, varying in color from plain ground-glass white through horncolor to brown or even purplish, unicolor or marked with interrupted spiral bands. Nuclear whorls 2 or more, strongly rounded, forming a somewhat truncated apex, the first half strongly granulose, the next turn minutely granulose, while the last half of the last turn shows faint indications of the beginnings of the axial threads, which become stronger as the shell increases in size and eventually merge into the postnuclear axial sculpture. Postnuclear whorls inflated, strongly rounded with the summit roundly shouldered, marked by retractively curved, closely spaced, sublamellar axial riblets, which are rendered wavy by the weakly developed spiral cords. At irregular intervals the axial riblets are more closely approximated than the succeeding or preceding ones, which lends the whorls a somewhat scalariform pattern. Suture strongly constricted. Periphery of the last whorl strongly rounded; base inflated, strongly rounded, openly broadly umbilicated, marked by the continuation of the axial ribs and spiral threads, the latter becoming usually more intensified on the umbilical wall within the umbilicus. The last whorl in adult shells is usually solute for some little distance; the outside of the parietal wall being there marked by the continuation of the axial ribs. Aperture varying from very broadly oval to subcircular with a slight angulation at the posterior angle. The peristome is very narrowly expanded and reflected. The operculum is thin, multispiral, horny with a fine granulose, calluslike deposit which is heaviest on the inner margin and thins out, vanishing about the middle or a little beyond the middle of the whorls. This deposit is present in more or less wavy or threadlike depositions and lends to the outer surface of the operculum a slightly corrugated pattern.

The animal of Chondropometes (Chondropometes) vignalense is rather short and has the sole of the foot divided by a median longitudinal cleft, the locomotion being effected alternately by the two sides. The tentacles are slightly expanded laterally near the tip.

In $C$. $(C$.) vignalense vignalense the body is pale smoky gray on the sides. Forehead and top of the body darker. Sole of the foot flesh-color, with smoky suffusion, which is also the color of the snout. Tentacles smoky gray at base, gradually changing to yellowish-olive toward the tip. This is also the color of $C$. $(C$.) vignalense clappi.

The animal of $C$. $(C$.) vignalense puertecitense may be described as follows: Flesh-color, with a smoky-gray tinge. Tip of the head, snout, and basal half of the tentacles bluish smoky gray, the snout portion having a brownish flush. The tip of the tentacles is olive- 
green, a little darker at the expanded distal portion. The edge of the snout is flesh-color. Sole of the foot flesh-color. The internal anatomy behind and between the tentacles appears pinkish and shines through the substance of the tissue.

Of the animal of $C .(C$.$) vignalense fogonense we have taken the$ following notes: Flesh-color, with a smoky suffusion; base of tentacles, forehead, and snout ashy gray. The distal portion of the tentacles is pale orange in color, not expanded at the tip; edge of snout paler than the region behind it. When resting the animal suspends itself by a mucous thread.

Distribution of the subspecies of $C$. $(C$.) vignalense is shown in figure 72 .

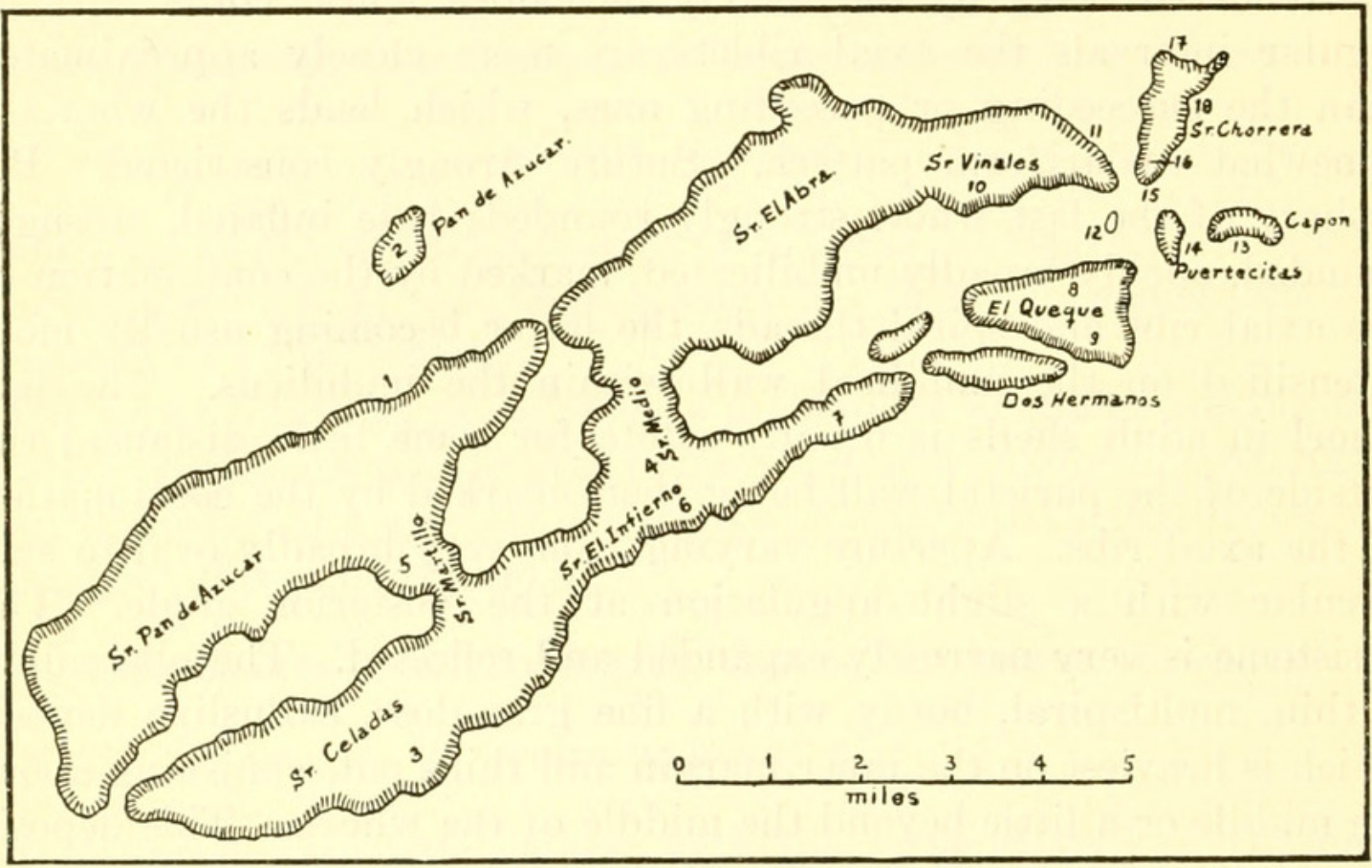

Figure 72.-Distribution of the subspecies of Chondropometes (Chondropometes) vignalense: (1) azucarense; (2) azucarellum; (3) celadense; (4) lucifer; (5) martillense; (6) infernale; (7) poenitentis; (8) bruneocinctum; (9) venerabile; (10) ignicolor; (11) piadae; (12) palmaritense; (13) caponense; (14) puertecitense; (15) vignalense; (16) jarucense; (17) clappi; (18) fogonense.

KEY TO THE SUBSPECIES OF CHONDROPOMETES (CHONDROPOMETES) VIGNALENSE

Shell uniformly ground-glass white.

Greater diameter more than $20 \mathrm{~mm}$ clappi

Greater diameter less than $18 \mathrm{~mm}$ vignalense

Shell not uniformly ground-glass white.

Shell ground-glass white but with a broad pale straw-colored

axial band a little distance behind the peristome_-_-_-_-_-_- venerabile

Shell not as above.

Shell pale straw-color.

Dark axial band behind aperture absent puertecitense Axial ribs distantly spaced. azucarellum 
Dark axial band behind aperture present.

Dark axial band behind the aperture strong fogonense

Dark axial band behind the aperture faint.

Axial sculpture decidedly lamellose. caponense

Axial sculpture not decidedly lamellose.

Axial ribs very closely spaced martillense

Axial ribs not very closely spaced celadense

Axial sculpture on spire obsolete lucifer Shell not pale straw-color.

Shell pale brown.

Shell not spirally banded.

Peristome white piadae

Peristome buff azucarense Peristome red ignicolor

Shell spirally banded.

Spiral bands very conspicuous.

Greater diameter $23.6 \mathrm{~mm}$ bruneocinctum Greater diameter $20 \mathrm{~mm}$ poenitentis

Spiral bands not very conspicuous.

Spiral bands almost continuous infernale Spiral bands discontinuous.

Axial sculpture sharply lamellose_-- palmaritense Axial sculpture less sharply lamellose_- jarucense

\section{CHONDROPOMETES (CHONDROPOMETES) VIGNALENSE CLAPPI, new subspecies}

\section{Plate 7, Figure 11}

This delicate, thin-shelled, translucent, ground-glass white race comes from the north end of the Sierra de la Chorrera. We gathered more than 100 specimens about the cave from which a small stream issues.

The type, U.S.N.M. no. 428786, is a complete specimen having 6 whorls and measuring: Length, $22.4 \mathrm{~mm}$; greater diameter, $22.0 \mathrm{~mm}$; lesser diameter, $16.0 \mathrm{~mm}$. It is named for Dr. George Clapp, who was a member of the Tomas Barrera Expedition when we obtained most of our specimens.

CHONDROPOMETES (CHONDROPOMETES) VIGNALENSE VIGNALENSE (Wright) Pfeiffer

\section{Plate 7, Figure 8}

1863. Chondropoma vignalense (Wright) PFEIFFER, Malakozool. Blätter, vol. 10, p. 189.

Wright, in his travels through western Cuba, was the first to make known this species, and he distributed his material under the general label "Vinales." We know from various other species collected by Wright that he gathered material about the southeast end of the Sierra de la Chorrera, and recent collecting here has produced material that is in every way comparable with the specimens in our collection received from Wright. It seems proper, therefore, that the race occu- 
pying this end of this limestone block should be considered the type locality of the typical race.

The shells of this race resemble closely $C$. $(C$.$) vignalense clappi in$ delicacy and color, but they are much smaller.

The specimen figured, U.S.N.M. no. 468679, comes from the southeastern end of the Sierra Chorrera. It is a complete individual, having 5.8 whorls and measuring: Length, $18.2 \mathrm{~mm}$; greater diameter, $17.8 \mathrm{~mm}$; lesser diameter, $12.5 \mathrm{~mm}$.

CHONDROPOMETES (CHONDROPOMETES) VIGNALENSE VENERABILE, new subspecies

Plate 8, Figure 11

This was collected in the Hoyo de los Santos of El Queque. It is of ground-glass white color, with a straw-colored axial band a little behind the peristome.

The type, U.S.N.M. no. 428788 , has 3.3 whorls remaining and measures: Length, $21.2 \mathrm{~mm}$; greater diameter, $22.5 \mathrm{~mm}$; lesser diameter, $15.6 \mathrm{~mm}$.

CHONDROPOMETES (CHONDROPOMETES) VIGNALENSE PUERTECITENSE, new subspecies

Plate 7, Figure 9

Shell very similar to $C$. $(C$.) vignalense vignalense but pale yellow. This subspecies comes from Mogote Puertecitas off the southeast end of the Chorrera.

The type, U.S.N.M. no. 468680, is a complete specimen having 5.5 whorls and measures: Length, $17.7 \mathrm{~mm}$; greater diameter, $17.2 \mathrm{~mm}$; lesser diameter, $12.7 \mathrm{~mm}$.

CHONDROPOMETES (CHONDROPOMETES) VIGNALENSE AZUCARELLUM, new subspecies

Plate 7, Figure 6

Shell small, pale yellow, resembling $C$. $(C$.) vignalense puertecitense in size and coloration but having the axial riblets much more numerous and much more closely spaced.

The type, U.S.N.M. no. 429046, was collected by G. Homer on Mogote Pan de Azucar. It has 2.5 whorls remaining and measures: Length, $16.6 \mathrm{~mm}$; greater diameter, $18.5 \mathrm{~mm}$; lesser diameter, 13.0 $\mathrm{mm}$.

CHONDROPOMETES (CHONDROPOMETES) VIGNALENSE FOGONENSE, new subspecies

Plate 8, Figure 4

This subspecies comes from Fogon de los Negros in the northeastern part of de la Chorrera. It is a small race resembling $C$. $(C$.) 
vignalense puertecitense, but it can at once be distinguished from this by its having a broad dark smoke-colored axial zone a little behind the peristome.

The type, U.S.N.M. no. 468682, has 4.2 whorls remaining and measures: Length, $17.0 \mathrm{~mm}$; greater diameter, $18.7 \mathrm{~mm}$; lesser diameter, $14.0 \mathrm{~mm}$.

CHONDROPOMETES (CHONDROPOMETES) VIGNALENSE CAPONENSE, new subspecies

Plate 7, Figure 4

Shell very pale buff, with a pale brown axial band a little behind the peristome, which is pale buff.

The type, U.S.N.M. no. 428792, which comes from Mogote Capon, has 3 whorls remaining and measures: Length, $17.5 \mathrm{~mm}$; greater: diameter, $18.9 \mathrm{~mm}$; lesser diameter, $13.7 \mathrm{~mm}$.

CHONDROPOMETES (CHONDROPOMETES) VIGNALENSE MARTILLENSE, new subspecies

Plate 7, Figure 5

This subspecies comes from the Cueva del Martillo, which is situated in the ridge that connects the Sierra de Chichones with the Sierra de los Celadas and Sierra del Infierno at their junction; it is called Martillo. It is a little darker in color than $C$. $(C$.) vignalense celadense and has the axial ribs much more closely spaced.

The type, U.S.N.M. no. 468684, is a complete specimen having 5.5 whorls and measuring: Length, $17.0 \mathrm{~mm}$; greater diameter, $17.0 \mathrm{~mm}$; lesser diameter $13.0 \mathrm{~mm}$.

CHONDROPOMETES (CHONDROPOMETES) VIGNALENSE CELADENSE, new subspecies

Plate 7, Figure 7

This comes from the Sierra Celadas. The shell is pale straw-colored, but there is an intensification of the color a little behind the peristome, which gives the shell at this place a faintly vertically banded aspect.

The type, U.S.N.M. no. 428799 , has a little more than 4 whorls remaining and measures: Length, $17.8 \mathrm{~mm}$; greater diameter, 18.6 $\mathrm{mm}$; lesser diameter, $14.2 \mathrm{~mm}$.

\section{CHONDROPOMETES (CHONDROPOMETES) VIGNALENSE LUCIFER, new subspecies}

Plate 8, Figure 2

This subspecies was also collected by Father Roca; likewise by Aguayo and Bermudez at a much higher altitude than $C$. $(C$.) vignalense infernale, in the Sierra del Infierno. It is at once distinguished from that subspecies by its much paler color and absence of $66879-38-2$ 
spiral banding. It also has a pale buff axial band a little behind the aperture. The axial and spiral sculpture are both much reduced.

The type, U.S.N.M. no. 367734, has 3.5 whorls remaining and measures: Length, $21.4 \mathrm{~mm}$; greater diameter, $24.0 \mathrm{~mm}$; lesser diameter, $14.6 \mathrm{~mm}$.

CHONDROPOMETES (CHONDROPOMETES) VIGNALENSE PIADAE, new subspecies

Plate 7, Figure 2

Shell pale brown except the peristome, which is white. There is a slight intensification of the brown color as a pale axial band a little behind the peristome.

The type, U.S.N.M. no. 367730, comes from El Ancon of the Sierra Vinales. It has 3.5 whorls remaining and measures: Length, 21.3 $\mathrm{mm}$; greater diameter, $22.8 \mathrm{~mm}$; lesser diameter, $17.2 \mathrm{~mm}$.

A considerable series of specimens from the east side of the Sierra Vinales agree splendidly with the type.

CHONDROPOMETES (CHONDROPOMETES) VIGNALENSE AZUCARENSE, new subspecies

Plate 7, Figure 1

This comes from Pan de Azucar. Its color is very pale brown with the peristome buff.

The type, U.S.N.M. no. 354916, we collected on the Tomas Barrera Expedition in 1914 at the base of Pan de Azucar. It has 3.7 whorls remaining and measures: Length, $17.3 \mathrm{~mm}$; greater diameter, 22.1 $\mathrm{mm}$; lesser diameter, $15.8 \mathrm{~mm}$.

CHONDROPOMETES (CHONDROPOMETES) VIGNALENSE IGNICOLOR, new subspecies

Plate 8, Figure 10

This subspecies is strikingly colored, its general color being pale orange, while the peristome is reddish orange, almost flame-color.

The type, U.S.N.M. no. 428787, was collected in Hoyo Magdalena in the Costanera de San Vicente, Vinales. It has 3.5 whorls remaining and measures: Length, $22.5 \mathrm{~mm}$; greater diameter, $23.0 \mathrm{~mm}$; lesser diameter, $16.0 \mathrm{~mm}$.

CHONDROPOMETES (CHONDROPOMETES) VIGNALENSE BRUNEOCINCTUM, nEW subspecies

Plate 7, Figure 10

This subspecies also comes from Sierra Tumbadero, which has been more recently called El Queque, but from another locality than that occupied by $C$. $(C$.) vignalense venerabile. It ranges from pale brown to darker brown and is marked with slender, somewhat interrupted, 
spiral bands of darker brown, which are intensified in definite axial regions to form almost a varicial element. There is also a darker zone of brown a little behind the peristome, the latter being yellowish white.

The type, U.S.N.M. no. 428789, is a perfect specimen having 6.2 whorls and measuring: Length, $23.7 \mathrm{~mm}$; greater diameter, $23.6 \mathrm{~mm}$; lesser diameter, $17.0 \mathrm{~mm}$.

CHONDROPOMETES (CHONDROPOMETES) VIGNALENSE POENITENTIS, new subspecies

Plate 7, Figure 3

This subspecies resembles $C$. $(C$.) vignalense bruneocinctum but is considerably smaller and usually has a decidedly purplish tinge. It appears to range from the mogotes Dos Hermanos to Cuajaní to La Penitencia.

The type, U.S.N.M. no. 468701, was collected at the Cafetal de la Penitencia. The type is a complete specimen, having 6.0 whorls and measuring: Length, $20.0 \mathrm{~mm}$; greater diameter, $20.0 \mathrm{~mm}$; lesser diameter, $15.9 \mathrm{~mm}$.

CHONDROPOMETES (CHONDROPOMETES) VIGNALENSE INFERNALE, new subspecies

Plate 8, Figure 7

This exceedingly delicate shell is semitranslucent, of pale brown color, and marked by slender spiral bands, which are almost continuous on the last whorl. The peristome is pale orange.

The type, U.S.N.M. no. 367731, was collected by Father Roca at Sitio del Infierno, southwest of Vinales. It has a little more than 3 whorls remaining and measures: Length, $21.0 \mathrm{~mm}$; greater diameter, $21.9 \mathrm{~mm}$; lesser diameter, $15.3 \mathrm{~mm}$.

\section{CHONDROPOMETES (CHONDROPOMETES) VIGNALENSE PALMARITENSE, new subspecies}

\section{Plate 8, Figure 5}

Shell pale brown with a decidedly darker axial zone a little behind the peristome, which is white. It is obscurely interruptedly spirally banded. These markings, however, have to be looked for or they will be overlooked on account of their faintness.

This subspecies, while resembling $C$. $(C$.) vignalenise bruneocinctum, is readily distinguished from that by its decidedly smaller size and fainter spiral markings.

The type, U.S.N.M. no. 428791, was collected by Bartsch on Mogote Palmarito. It has 3.5 whorls remaining and measures: Length, $16.8 \mathrm{~mm}$; greater diameter, $19.2 \mathrm{~mm}$; lesser diameter, $14.0 \mathrm{~mm}$. 
CHONDROPOMETES (CHONDROPOMETES) VIGNALENSE JARUCENSE, new subspecies

\section{Plate 8, Figure 8}

Shell small, pale brown, with rather distant, inconspicuous, interrupted, pale brown spiral bands. There is also an axial brown zone a little distance behind the yellowish-white peristome, which extends over the parietal wall of the umbilicus.

The type, U.S.N.M. no. 367732, was collected by Father Roca in the Hoyo de Jaruco, a sink located on the high parts of the east side of the Chorrera. It has 3.5 whorls remaining and measures: Length, $17.4 \mathrm{~mm}$; greater diameter, $18.1 \mathrm{~mm}$; lesser diameter, $14.0 \mathrm{~mm}$.

\section{Subgenus Chondrothyroma Henderson and Bartsch}

1920. Chondrothyroma Henderson and Barisch, Proc. U. S. Nat. Mus., vol. 58, p. 63.

Shell turbinate, openly umbilicate, and marked by axial ribs only, except on the umbilical wall, which shows spiral threads of varying strength in the different races. Breathing pore present on the parietal wall behind the peristome near the posterior angle of the aperture, except in Chondropometes (Chondrothyroma) scopulomim perplexum, and $C(C$.$) magnum magnum in which the pore is some-$ times absent. Aperture subcircular; peristome broadly expanded and reflected, marked by concentric lines of growth which sometimes suggest lamellae, fluted or smooth. The operculum is multispiral, the whorls having a heavy callus deposit on the inner two-thirds, which is somewhat fluted. This also varies in color in the different races from white to red.

Type: Chondropometes (Chondrothyroma) sagebieni (Poey).

This subgenus ranges from Mendoza on the west eastward through the Luis Lazo region along the south side of the Organ Mountains, and the mogotes adjacent to them, to San Diego de los Banos, bending northward to the Sierra la Cumbre, then to the westward to the Sierra San Andrés. The group therefore occupies a distinct range in the Province of Pinar del Rio from that occupied by members of the subgenus Chondropometes, except in the Sierra Galalón, Guacamayas, and San Andrés, where two subgenera overlap.

We are recognizing nine species in the subgenus and quite a number of subspecies under these, each of which has its circumscribed zoogeographic distribution.

\section{KEY TO THE SPECIES OF SUBGENUS CHONDROTHYROMA}

Operculum red.

Greater diameter more than $21 \mathrm{~mm}$ eximium

Greater diameter less than $18 \mathrm{~mm}$.

Axial dark band behind peristome present exquisitum 
Axial dark band behind peristome absent.

Shell red or reddish

Shell not red or reddish.

Shell white or yellowish________- concolor

Operculum white.

Shell red.

Axial ribs rather distantly spaced magnum

Axial ribs rather closely spaced saccharinum

Shell white or buff.

Shell banded segregatum

Shell not banded scopulorum

Chondropometes (Chondrothyroma) bellissimum has not been considered in this key for want of operculum. It has the size of $C$. $(C$.) exquisitum but lacks the dark axial band behind the peristome and has much lower and closer spaced axial ribs.

\section{CHONDROPOMETES (CHONDROTHYROMA) EXIMIUM, new species}

Shell large, resembling $C$. $(C$.) magnum in shape, but with the axial ribs much finer and closer spaced and the operculum red.

Three races of this species are known. They occupy parts of the Sierra de los Acostas, Sierra San Carlos, and the Sierra del Quemado.

Distribution of the subspecies of $C .(C$.$) eximium is shown in$ figure 73 .

\section{KEY TO THE SUBSPECIES OF CHONDROPOMETES (CHONDROTHYROMA) EXIMIUM}

Spiral markings absent eximium Spiral markings not absent.

Spiral markings confined to the varicial bands angusticulum Spiral markings not confined to the varicial bands malleatum

CHONDROPOMETES (CHONDROTHYROMA) EXIMIUM EXIMIUM, new subspecies

Plate 10, Figure 4

Shell large, pale yellowish, which is also the color of the peristome, the inner being a little paler than the expanded portion, without spiral bands. Axial ribs closely spaced. Spiral threads on the umbilical wall very faint. Operculum red.

The type, U.S.N.M. no. 354925, was collected by Wright at Isabel Maria. It has 4 whorls remaining and measures: Length, $23.2 \mathrm{~mm}$; greater diameter, $22.3 \mathrm{~mm}$; lesser diameter, $15.6 \mathrm{~mm}$.

CHONDROPOMETES (CHONDROTHYROMA) EXIMIUM ANGUSTICULUM, new subspecies

\section{Plate 10, Figure 5}

Shell pale yellow with obsolete spiral bands, which are intensified at irregular intervals, which coincide in axial series. Peristome white; umbilical wall marked by obsolete spiral threads. 
The type, U.S.N.M. no. 428801, was collected by Bartsch under a grant from the Walter Rathbone Bacon Traveling Scholarship in

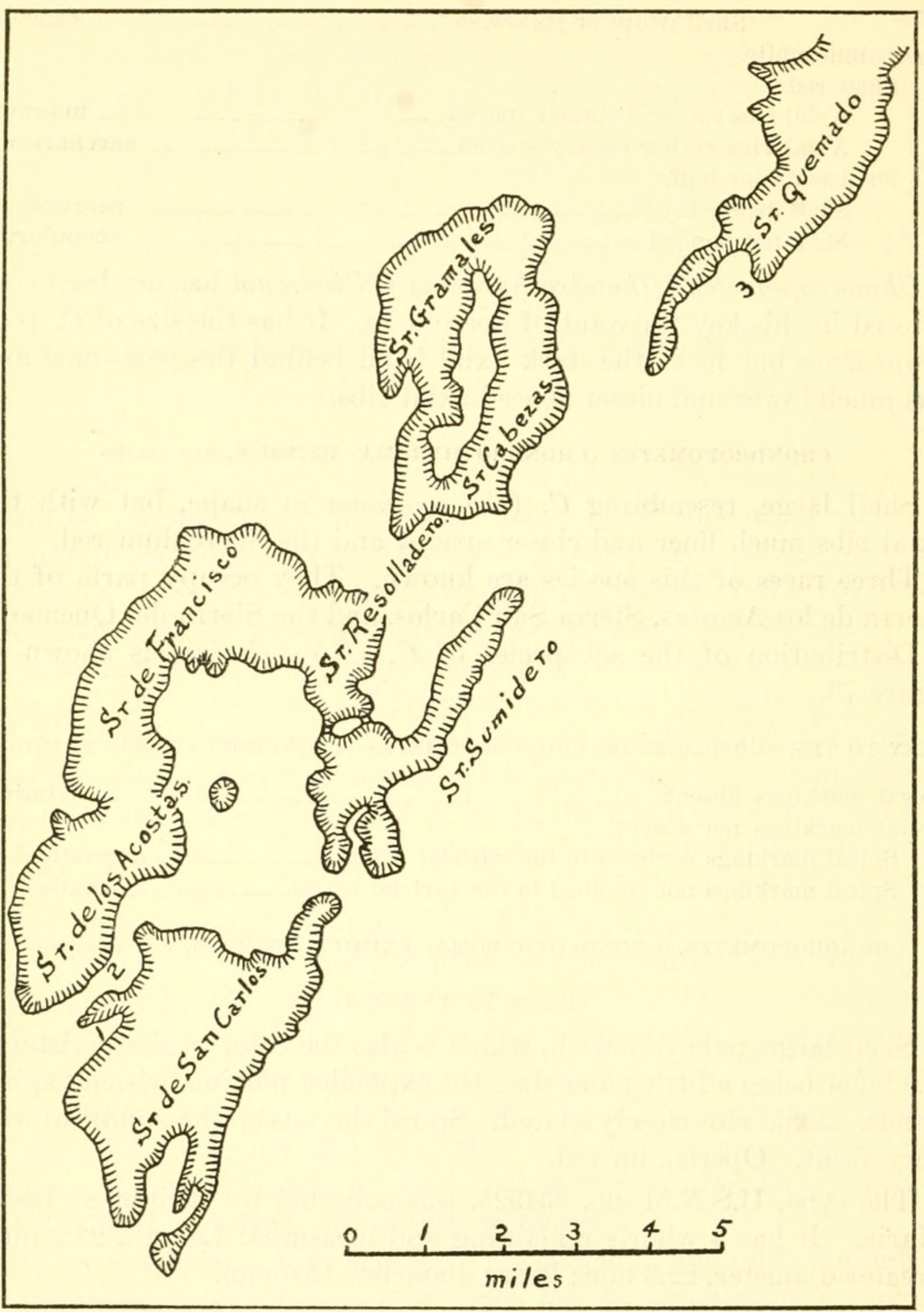

FIGURE 73.-Distribution of the subspecies of Chrondropometes (Chrondrothyroma) exim. ium: (1) angusticulum; (2) malleatum; (3) eximium.

1928 , in a small ensenada in the Sierra San Carlos east of the southern extremity of the Sierra de los Acostas. It has 3.8 whorls remaining and measures: Length, $22.3 \mathrm{~mm}$; greater diameter, $22.0 \mathrm{~mm}$; lesser diameter, $14.5 \mathrm{~mm}$. 
Plate 10, Figure 3

Shell large, thin, feebly distantly ribbed, pale yellow, the last whorl malleated, and marked by very conspicuous strong interrupted brown spiral bands. Peristome pale yellow; operculum brilliant red.

The type, U.S.N.M. no. 428802, was collected by Dominguez in the height on the west side of La Estrechura, which is the eastern wall of the southern end of Sierra de los Acostas. It has 4.1 whorls remaining and measures: Length, $24.5 \mathrm{~mm}$; greater diameter, $21.9 \mathrm{~mm}$; lesser diameter, $15.3 \mathrm{~mm}$.

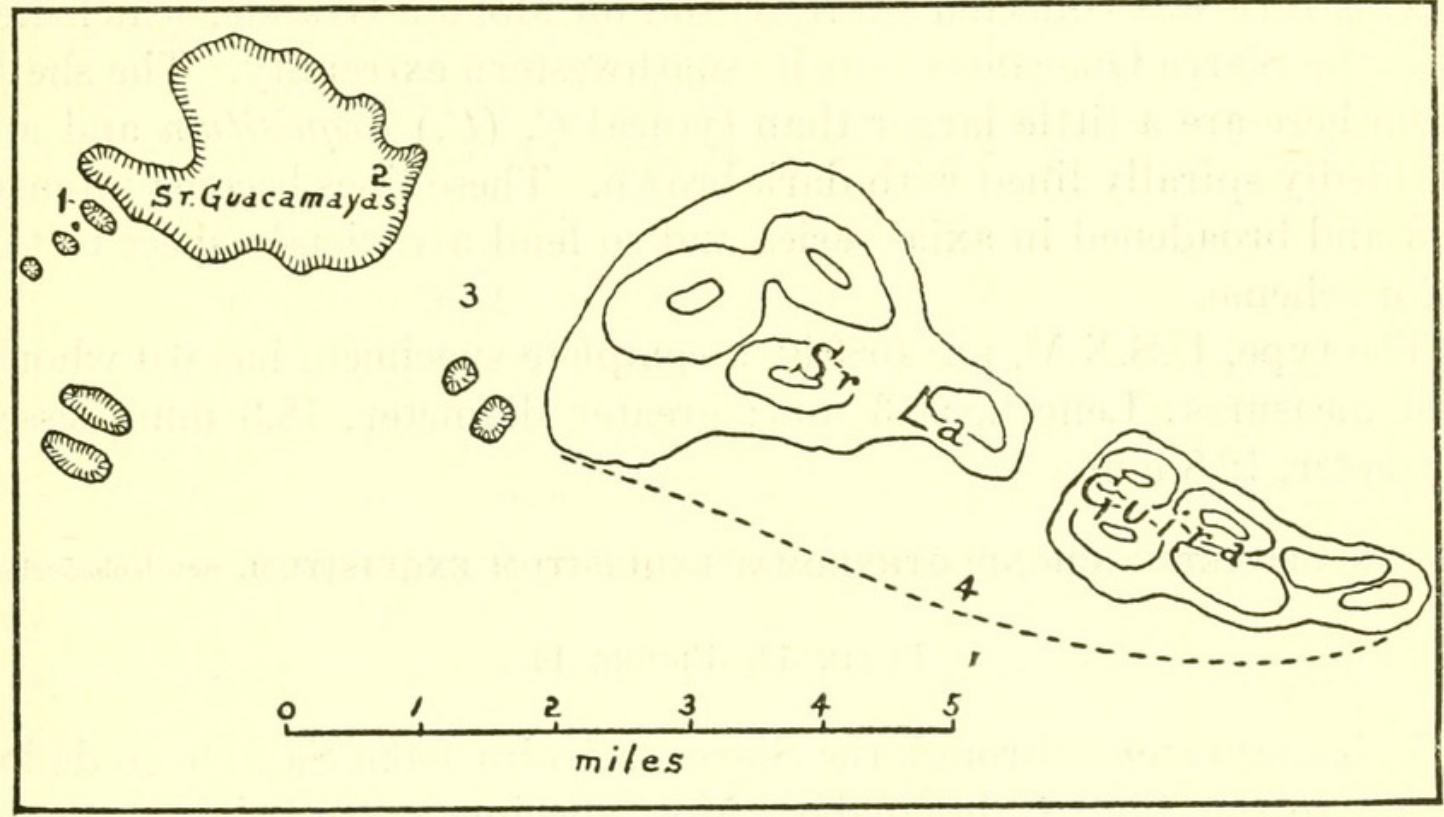

Figure 74.-Distribution of the subspecies of Chondropometes (Chondrothyroma) exquisitum: (1) punctolineatum; (2) cereum; (3) notatum; (4) exquisitum.

\section{CHONDROPOMETES (CHONDROTHYROMA) EXQUISITUM, new species}

Shell turbinate, of medium size with red operculum, and a darker axial zone immediately behind the peristome. Peristome white or pale yellow. The shell may be white, faintly yellow, wax colored, or dark orange-red; it may be unicolor or spirally banded.

The animal of $C .(C$.$) exquisitum punctolineatum has the upper$ part of the body smoky gray; sides, sole of foot, and snout flesh-color with smoky suffusion. Tentacles sooty black. Sole medially cleft; motion of the two sides alternate. Suspends itself by mucous thread.

This species ranges from the eastern end of the Sierra San Andrés through the Sierra Pico Chico to the Sierra la Guira, and some of the mogotes south of these limestone blocks.

Distribution of the subspecies of $C .(C$.$) exquisitum is shown in$ figure 74 . 
KEY TO THE SUBSPECIES OF CHONDROPOMETES (CHONDROTHYROMA) EXQUISITUM

Shell banded.

Shell red or reddish.

Spiral bands strongly expressed punctolineatum

Spiral bands feebly expressed exquisitum

Shell flesh-color notatum Shell not banded cereum

\section{CHONDROPOMETES (CHONDROTHYROMA) EXQUISITUM PUNCTOLINEATUM, nEW subspecies}

Plate 11, Figure 15

This race was collected by Natenson on Mogote Grande, which lies near the Sierra Guacamayas at its southwestern extremity. The shells from here are a little larger than typical $C$. $(C$.) exquisitum and are decidedly spirally lined with dark brown. These lines become intensified and broadened in axial series and so lend a varicial aspect to the color scheme.

The type, U.S.N.M. no. 468940 , a complete specimen, has 6.0 whorls and measures: Length, $20.3 \mathrm{~mm}$; greater diameter, $18.3 \mathrm{~mm}$; lesser diameter, $12.8 \mathrm{~mm}$.

CHONDROPOMETES (CHONDROTHYROMA) EXQUISITUM EXQUISITUM, new subspecies

Plate 11, Figure 14

This race ranges through: the Sierra la Guira from San Diego de los Banos to the Abra Caiguanabo. Most specimens are bright orangered, but the color ranges from this to yellow; there is always a dark axial band behind the expanded white peristome. While the shell appears unicolor, it is nevertheless obscurely banded. The spiral markings are usually reauced to mere elongate dots, which are arranged in axial series.

The type, U.S.N.M. no. 468722 , is a complete specimen, having 6.1 whorls, and comes from the west end of the Sierra la Guira. It measures: Length, $19.7 \mathrm{~mm}$; greater diameter, $16.0 \mathrm{~mm}$; lesser diameter, $14.1 \mathrm{~mm}$.

CHONDROPOMETES (CHONDROTHYROMA) EXQUISITUM NOTATUM, new subspecies

Plate 11, Figure 11

Shell white, except for a dark purplish axial band immediately behind the aperture and slender, interrupted, but distinct, spiral bands of brown; peristome white.

The type, U.S.N.M. no. 428803, was collected near the Cueva Oscura del rio Caiguanabo at Los Portales. It is an almost complete speci- 
men, having 5.2 whorls remaining, and measures: Length, $19.0 \mathrm{~mm}$; greater diameter, $16.9 \mathrm{~mm}$; lesser diameter, $11.8 \mathrm{~mm}$.

The distribution of this race, so far as known, ranges from Los Portales into the Abra de Caiguanabo, where it meets $C$. $(C$.) exquisitum exquisitum.

CHONDROPOMETES (CHONDROTHYROMA) EXQUISITUM CEREUM, new subspecies

Plate 11, Figure 13

Shell pale wax yellow, darker on the early whorls, with a moderately broad and not very dark axial band of brown immediately behind the peristome, which is faintly yellowish.

The type, a complete specimen, U.S.N.M. no. 428804, comes from the east end of the Sierra Guacamayas. It has 6.0 whorls and measures: Length, $18.4 \mathrm{~mm}$; greater diameter, $17.2 \mathrm{~mm}$; lesser diameter, $12.0 \mathrm{~mm}$.

\section{CHONDROPOMETES (CHONEROTHYROMA) SAGEBIENI (Poey)}

This species embraces small shells of bright red or reddish color with red operculum. It occupies the region between Mendoza or Paso Real eastward through the Sierra Guane to mogote Punta de la Sierra. It breaks up into five subspecies, which the following key will help to differentiate.

Distribution of the subspecies of $C$. $(C$.) sagebieni is shown in figure 75 .

KEY TO THE SUBSPECIES OF CHONDROPOMETES (CHONDROTHYROMA) SAGEBIENI

Shell bright red sagebieni

Shell not bright red, but reddish.

Axial brown zones conspicuous.

Interrupted spiral bands conspicuous portalesense

Interrupted spiral bands not conspicuous mendozense Axial brown zones not conspicuous.

Peristome red parvum

Peristome white disjunctum

\section{CHONDROPOMETES (CHONDROTHYROMA) SAGEBIENI SAGEBIENI (Poey)}

Plate 11, Figure 1

1858. Cyclostoma sagebieni PoEx, Memorias sobre la historia natural de la Isla de Cuba, vol. 2, p. 33.

This is a little smaller than $C$. $(C$.) sagebieni mendozense and of bright red color, with an even more flaming peristome. The color extends a little beyond the peristome on the last whorl. No spiral markings have been observed on any of the specimens. 


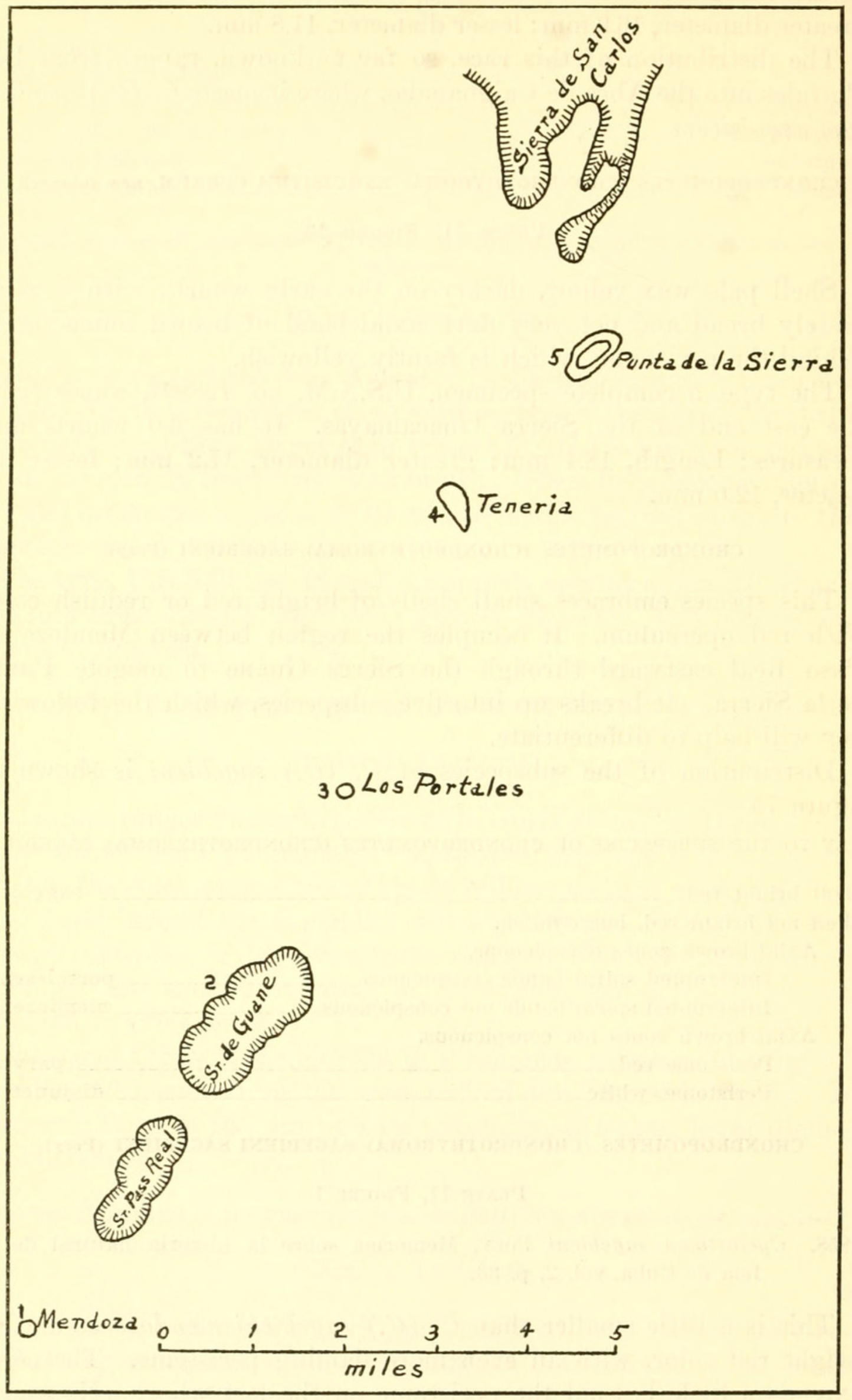

Figure 75.-Distribution of the subspecies of Chrondropometes (Chondrothyroma) sagebieni: (1) mendozense; (2) sagebieni; (3) portalesense; (4) parvum; (5) disjunctum. 
The specimen figured, U.S.N.M. no. 355012, is one of a series from Sierra de Guane. It has 3.5 whorls and measures: Length, $16.2 \mathrm{~mm}$; greater diameter, $13.7 \mathrm{~mm}$; lesser diameter, $11.0 \mathrm{~mm}$.

CHONDROPOMETES (CHONDROTHYROMA) SAGEBIENI PORTALESENSE, new subspecies

Plate 11, Figure 12

Shell pale red, with the inner peristome and the region immediately behind the peristome on the last whorl a fiery red. The shell is strongly, almost continuously, spirally banded. These spiral markings are accentuated at intervals and produce an axially as well as a spirally banded effect.

The type, U.S.N.M. no. 367737, was collected by Dr. de la Torre at Los Portales. It has 3.5 whorls remaining and measures: Length, $15.7 \mathrm{~mm}$; greater diameter, $13.8 \mathrm{~mm}$; lesser diameter, $9.7 \mathrm{~mm}$.

\section{CHONDROPOMETES (CHONDROTHYROMA) SAGEBIENI MENDOZENSE, new subspecies}

Plate 11, Figure 3

In this subspecies the shell is pale brown, the early whorls darker. The inner half of the peristome is flame red, the outer paler. This bright color also characterizes the rather broad axial band immediately behind the peristome. The whorls are marked by not strongly pronounced interrupted spiral bands of brown.

The type, U.S.N.M. no. 355015, and a series of this species we collected on the Tomas Barrera Expedition in a limestone block immediately adjacent to the station at Mendoza or Paso Real. This has nothing to do with the Sierra de Paso Real but is several miles southwest of this. The type has almost 4 whorls remaining and measures: Length, $18.3 \mathrm{~mm}$; greater diameter, $15.9 \mathrm{~mm}$; lesser diameter, $11.8 \mathrm{~mm}$.

CHONDROPOMETES (CHONDROTHYROMA) SAGEBIENI PARVUM, new subspecies

\section{Plate 11, Figure 5}

Shell very small, pale reddish with the early whorls rather darker in color. Inner peristome pale red; spiral bands present, but very inconspicuous.

The type, U.S.N.M. no. 367747, was collected by Arango at Teneria north of Portales. It has 4 whorls remaining and measures: Length, $13.0 \mathrm{~mm}$; greater diameter, $10.5 \mathrm{~mm}$; lesser diameter, $8.0 \mathrm{~mm}$.

A large series of specimens collected about La Murralia on both sides of the road agree rather well with the specimens from Teneria. 
CHONDROPOMETES (CHONDROTHYROMA) SAGEBIENI DISJUNCTUM, new subspecies

Plate 11, Figure 2

The shell of this subspecies is pale red; the peristome white. It is also inconspicuously spirally banded.

The type, U.S.N.M. no. 385118, was collected by Bartsch on the mogote off the tip point of Punta de la Sierra. This has 4 whorls remaining and measures: Length, $16.0 \mathrm{~mm}$; greater diameter, 15.2 $\mathrm{mm}$; lesser diameter, $10.7 \mathrm{~mm}$.

\section{CHONDROPOMETES (CHONDROTHYROMA) CONCOLOR, new species}

Shell small or very small, unicolor, white or yellow, marked by varicial axial streaks due to the fusion of several riblets, or without these. Nuclear whorls about 2, smooth, inflated, well rounded, finely granulose. The early postnuclear whorls distantly ribbed and the later ones more closely so. Peristome white or yellowish; operculum red.

This species is closely related to $C$. $(C$.) scopulorum but differs from it by the red or reddish operculum. It ranges from the Mogotes de Fonte southeast of the Sierra de San Andrés and Sierra Guacamayas to the Sierra Galalón and some mogotes south of these mountains. It occurs therefore west of $C$. $(C$.) scopulorum.

We recognize five subspecies in the material before us, which the following key will help to differentiate:

Distribution of the subspecies of $C(C$.) concolor is shown in figure 76 .

KEY TO THE SUBSPECIES OF CHONDROPOMETES (CHONDROTHYROMA) CONCOLOR

Shell pale orange concolor

Shell straw-color.

Spiral threads in umbilicus obsolete magister Spiral threads in umbilicus not obsolete.

Greater diameter less than $12 \mathrm{~mm}$ fontei Greater diameter more than $13 \mathrm{~mm}$. spe Shell not straw-color.

Shell flesh-color carnicolor

CHONDROPOMETES (CHONDROTHYROMA) CONCOLOR CONCOLOR, new subspecies

Plate 11, Figure 6

Shell pale orange; peristome white; operculum red. Axial ribs rather distantly spaced; spiral threads in the umbilicus rather feeble.

The type, U.S.N.M. no. 468723, a complete specimen from the low land of the eastern part of the Sierra Guacamayas, has 5.6 whorls and measures: Length, $17.0 \mathrm{~mm}$; greater diameter, $15.7 \mathrm{~mm}$; lesser diameter, $10.8 \mathrm{~mm}$. 
CHONDROPOMETES (CHONDROTHYROMA) CONCOLOR MAGISTER, new subspecies

Plate 11, Figure 8

Shell very thin, white with a very faint yellowish tinge, marked by varicial white streaks due to the fusion of several of the axial riblets. The axial ribs are rather low and closely spaced. The umbilical wall does not show spiral threads.

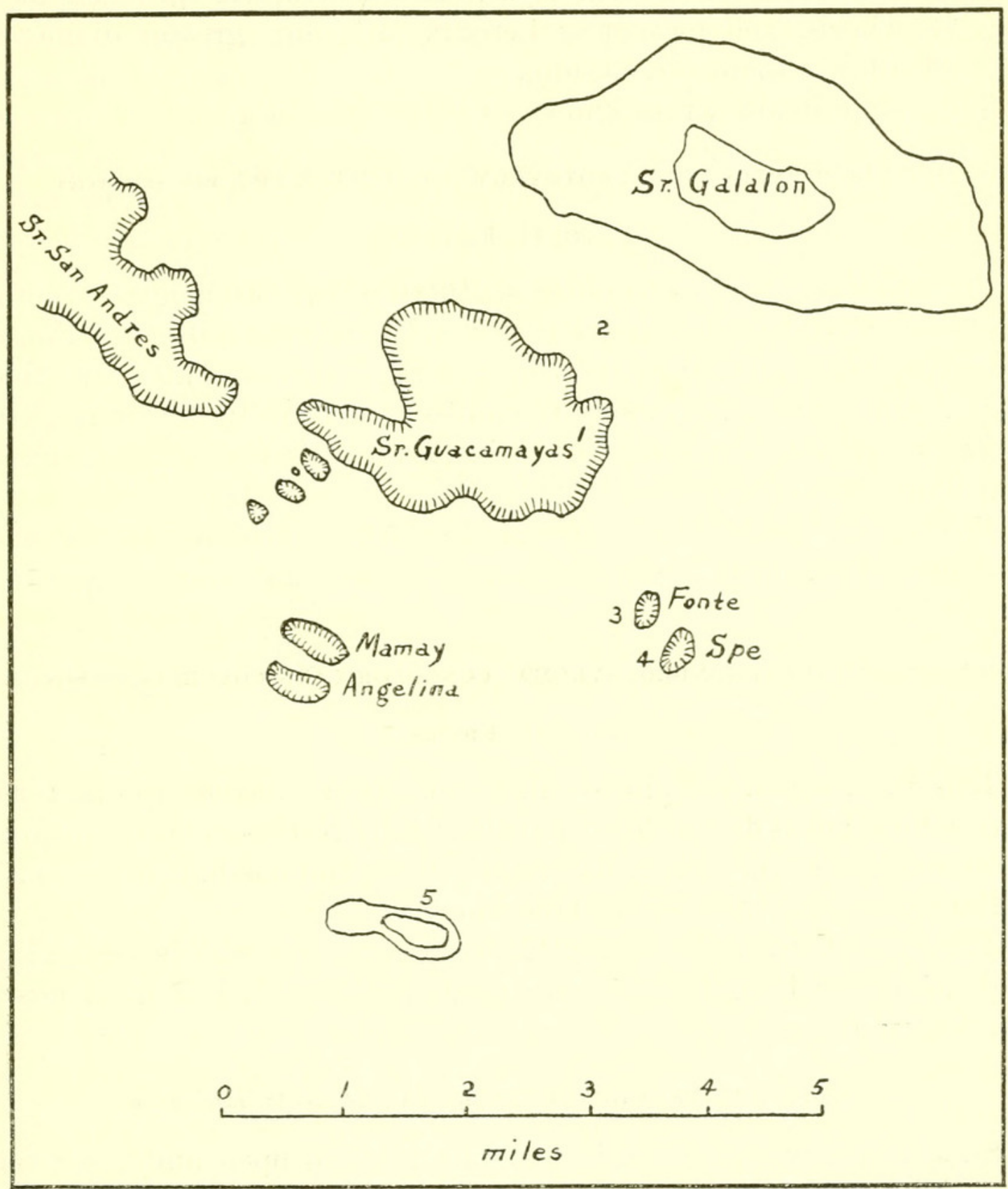

Figure 76.-Distribution of the subspecies of Chrondropometes (Chondrothyroma) concolor: (1) concolor; (2) magister; (3) fontei; (4) spe; (5) carnicolor.

The type, U.S.N.M. no. 367751, was collected between Galalón and Caiguanabo, without specific locality. It is a complete specimen, having 6.0 whorls, and measures: Length, $16.4 \mathrm{~mm}$; greater diameter, $15.4 \mathrm{~mm}$; lesser diameter, $10.3 \mathrm{~mm}$. 
CHONDROPOMETES (CHONDROTHYROMA) CONCOLOR FONTEI, new subspecies

\section{Plate 11, Figure 4}

Shell very small, white, with a mere yellowish flush; varicial streaks scarcely indicated. The umbilical wall is marked by feeble spiral threads.

The type, U.S.N.M. no. 428805, comes from the Mogote de Fonte southeast of the Sierra Guacamayas. It is a complete specimen, having 5.3 whorls, and measures: Length, $12.5 \mathrm{~mm}$; greater diameter, $11.0 \mathrm{~mm}$; lesser diameter, $8.0 \mathrm{~mm}$.

This is the smallest race known of this subspecies.

CHONDROPOMETES (CHONDROTHYROMA) CONCOLOR SPE, new subspecies

\section{Plate 11, Figure 9}

This subspecies comes from the southern of the two mogotes, southeast of San Andrés, which are collectively known as Mogotes Fonte. The second is embraced by the Finca la Esperanza and may take that name. This subspecies closely resembles that from the sister mogote, Fonte, $C$. $(C$.) concolor fonte $i$, but is a trifle larger and has the axial ribs more distantly spaced.

The type, U.S.N.M. no. 468724, has 5.5 whorls remaining and measures: Length, $15.2 \mathrm{~mm}$; greater diameter, $12.7 \mathrm{~mm}$; lesser diameter, $8.9 \mathrm{~mm}$.

CHONDROPOMETES (CHONDROTHYROMA) CONCOLOR CARNICOLOR, new subspecies

\section{Plate 11, Figure 7}

This race, which is quite similar to $C$. $(C$.$) concolor spe in form$ and ribbing but is flesh-color, was collected by Natenson on the mogote south of the Casa del Perez Rivera about one and one-half miles south and a little east of the Sierra Guacamayas.

The type, U.S.N.M. no. 468942 , has almost 4.0 whorls remaining and measures: Length, $13.7 \mathrm{~mm}$; greater diameter, $11.7 \mathrm{~mm}$; lesser diameter, $8.6 \mathrm{~mm}$.

\section{CHONDROPOMETES (CHONDROTHYROMA) MAGNUM, new species}

Shell large, turbinate, with moderately broad open umbilicus, red or reddish, unicolor or spirally banded. The peristome varies from white to pale reddish. The operculum is white. Nuclear whorls a little more than 2 , coiling in perfect harmony with the rest of the spire, inflated, strongly rounded; the first smooth, the next finely microscopically granulose, the last showing fine, closely spaced, microscopic incremental lines. Postnuclear whorls rather abruptly differentiated from the nuclear turn, inflated, strongly rounded, marked by 
very slender, retractively slanting lamellar axial ribs between which occasional finer threads appear. This, however, is not a regular arrangement. Suture strongly constricted; periphery well rounded. Base inflated, strongly rounded; the inner wall of the umbilicus is marked by moderately strong, well-rounded, spiral threads, which render the axial ribs somewhat serrulate at their junction. Aperture broadly oval or subcircular. Peristome double, the inner projecting slightly beyond the outer, and slightly expanded, smooth; the outer broadly expanded, marked by concentric lines of growth, not infrequently transversely fluted. Breathing pore a little within the peristome on the parietal wall near the posterior angle. Operculum almost circular, multispiral, the inner four-fifths covered with a rather strong calcareous deposit which gives it a corrugated appearance, the corrugations having a protracted slant.

This large species ranges through the Sierra de los Acostas, the Sierra de San Carlos, the Sierra del Sumidero, the Sierra de Cabezas, and the mogotes lying to the south thereof.

It breaks up into three well-defined zoogeographic races to which we are assigning subspecific rank.

Distribution of the subspecies of $C$. (C.) magnum is shown in figure 77 .

KEY TO THE SUBSPECIES OF CHONDROPOMETES (CHONDROTHYROMA) MAGNUM

Last whorl solute for one-tenth or more of a turn.

Last part of last whorl decidedly deflected elisabethae

Last part of last whorl not decidedly defiected magnum Last whorl almost adnate signae

CHONDROPOMETES (CHONDROTHYROMA) MAGNUM ELISABETHAE, new subspecies

Plate 12, Figure 12

Shell large, the early postnuclear whorls reddish, the rest buff, marked by rather conspicuous interrupted spiral bands, which are almost as broad as they are long and arranged in axial series. Peristome with a reddish flush on the inner half. The last half of the last whorl is decidedly solute.

The type, U.S.N.M. no. 367749, was collected by Bermudez at Isabel Maria northeast of Sumidero. It has 4.5 whorls remaining and measures: Length, $20.0 \mathrm{~mm}$; greater diameter, $18.0 \mathrm{~mm}$; lesser diameter, $12.5 \mathrm{~mm}$.

\section{CHONDROPOMETES (CHONDROTHYROMA) MAGNUM MAGNUM, new subspecies}

\section{Plate 12, Figure 13}

In this race the shell is large, ranging in color from pale brown to reddish brown. The peristome may be white or reddish; the outer always with concentric marks and usually with transverse 
flutings. The shell, as a rule, is interruptedly spirally banded, the spiral bands varying decidedly in conspicuousness, sometimes being

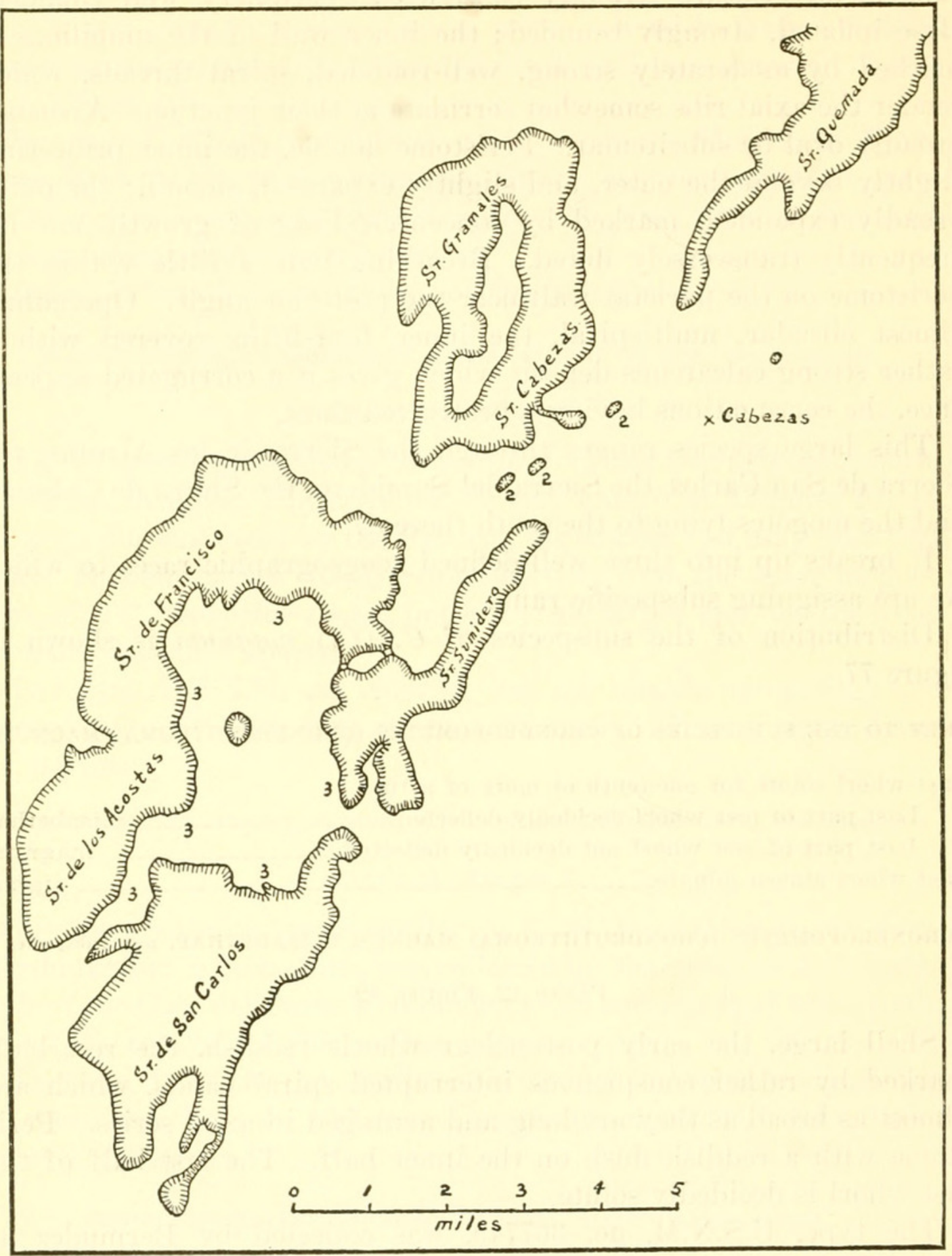

Figure 77.-Distribution of the subspecies of Chondropometes (Chondrothyroma) magnum: (1) elisabethae; (2) signae; (3) magnum.

almost absent. The segments are usually arranged in vertical series, which gives the shell a somewhat axially banded aspect.

This subspecies, we believe, ranges around the inner rim of the Portrero de Luis Lazo, including the Sierra de los Acostas, Sierra de San Carlos, and the Sierra del Sumidero.

The type, U.S.N.M. no. 355017, was collected on the west side of the Luis Lazo embrasure. It is almost complete and should have 
6.5 whorls. It measures: Length, $24.1 \mathrm{~mm}$; greater diameter, 18.4 $\mathrm{mm}$; lesser diameter, $13.3 \mathrm{~mm}$.

Two specimens of this subspecies have been found by Dr. de la Torre that do not have a breathing pore. One of these is U.S.N.M. no. 469125 ; the other is in Dr. de la Torre's collection.

CHONDROPOMETES (CHONDROTHYROMA) MAGNUM SIGNAE, new subspecies

\section{Plate 12, Figure 14}

Shell of medium size, thin, the early whorls reddish, the last one flesh-color, marked by rounded dots, which are arranged in both axial and spiral series. The peristome is white with a yellowish flush. The last whorl is almost adnate, being free only immediately behind the peristome, which is adnate to the preceding turn.

The type, U.S.N.M. no. 385144, and a series of specimens were collected by Bartsch while working under a grant from the Walter Rathbone Bacon Traveling Scholarship in 1928, on the three mogotes east of Cabezas. It has 3.6 whorls remaining and measures: Length, $17.0 \mathrm{~mm}$; greater diameter, $16.2 \mathrm{~mm}$; lesser diameter, $12.5 \mathrm{~mm}$.

CHONDROPOMETES (CHONDROTHYROMA) SACCHARINUM, new species

Shell large, varying in color from pale to dark reddish brown, with obsolete darker spiral bands. Axial ribs rather low and moderately closely spaced. Peristome white or pale brown. Operculum white.

This species, which is now known only from Pan de Azucar and the Cueva del Martillo, in the Sierra Martillo range that connects the Sierra Chichones with the Sierra Celadas and del Infierno, resembles $C$. (C.) magnum in size and color of operculum, while in strength of axial ribs and their spacing and in a lack of spiral lirations it approaches $C$. $(C$.) eximium, differing markedly from this, however, in the color of the operculum.

Distribution of the subspecies of $C$. $(C$.$) saccharinum is shown in$ figure 78 .

KEY TO THE SUBSPECIES OF CHONDROPOMETES (CHONDROTHYROMA) SACCHARINUM

Shell dark red rubicollum

Shell pale red saccharinum

CHONDROPOMETES (CHONDROTHYROMA) SACCHARINUM RUBICOLLUM, new subspecies

Plate 13, Figure 1

Shell dark reddish brown, with obsolete darker spiral bands and a brilliant red axial zone immediately behind the peristome; expanded peristome pale brown with a reddish suffusion.

$66879-38-3$ 
The type, U.S.N.M. no. 468847 , has 4.3 whorls remaining and measures: Length, $21.7 \mathrm{~mm}$; greater diameter, $18.8 \mathrm{~mm}$; lesser diameter, $14.2 \mathrm{~mm}$. It comes from the Sierra Martillo.

The brilliant red axial zone behind the peristome and darker coloration will readily distinguish this from $C$. $(C$.$) saccharinum$ saccharinum.

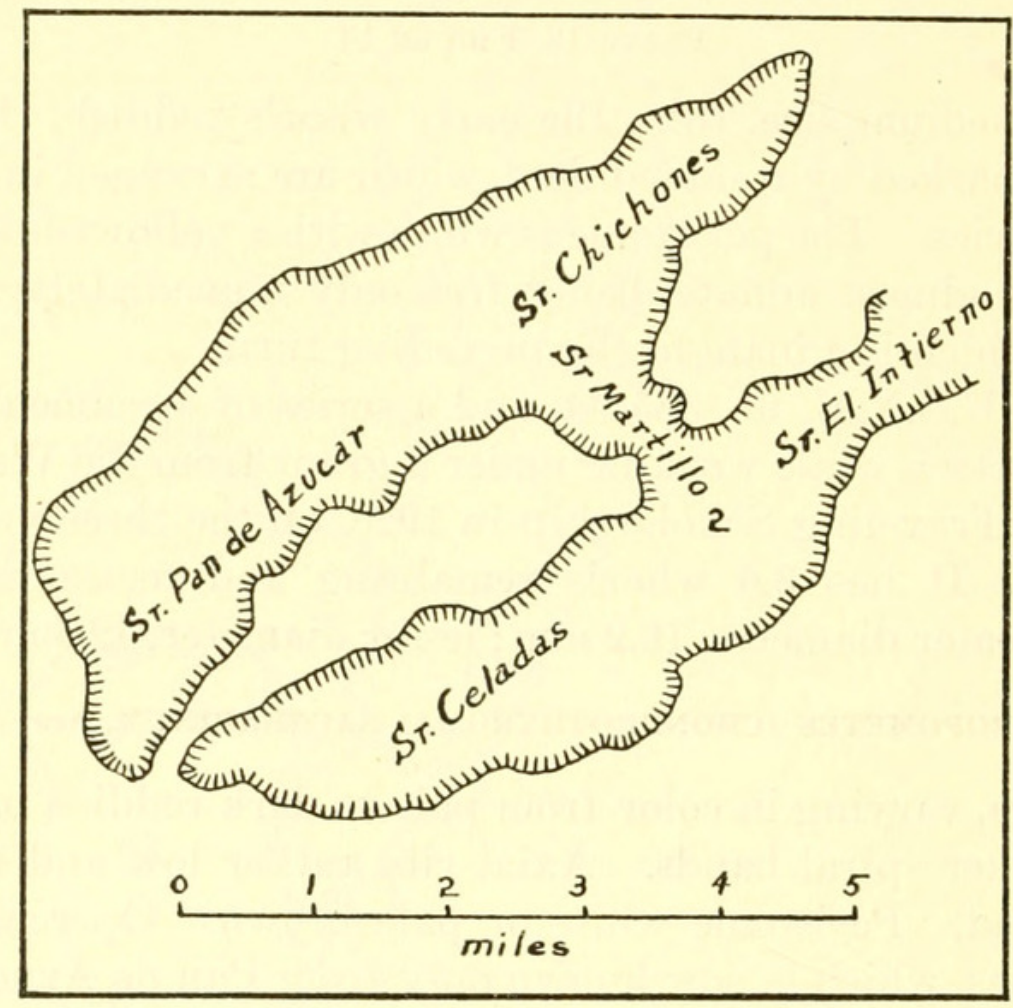

Figure 78.-Distribution of the subspecies of Chondropometes (Chondrothyroma) saccharinum: (1) saccharinum; (2) rubicollum.

\section{CHONDROPOMETES (CHONDROTHYROMA) SACCHARINUM SACCHARINUM, nEw subspecies}

\section{Plate 13, Figure 3}

This race, which comes from Pan de Azucar, is readily distinguished from $C$. $(C$.$) saccharinum rubicollum by its paler color and$ white peristome and by the absence of the brilliant-red axial zone behind the peristome.

The type, U.S.N.M. no. 355024, which was collected on the Tomas Barrera Expedition, has 4 whorls remaining and measures: Length, $19.2 \mathrm{~mm}$; greater diameter, $17.0 \mathrm{~mm}$; lesser diameter, $12.7 \mathrm{~mm}$.

\section{CHONDROPOMETES (CHONDROTHYROMA) SEGREGATUM, new species}

Shell of small or medium size, white, straw-color, pale buff, or sometimes faintly reddish, usually marked by interrupted spiral bands, which vary much in size and intensity of color and are present on both spire and base. Peristome pale yellowish or white. 
Nuclear whorls about 1.5, inflated, strongly rounded, continuing the outline of the postnuclear spire in their coiling. Postnuclear whorls strongly inflated and separated by a strongly impressed suture and marked on the early whorls by very strong lamellar, retractively slanting, axial riblets, which become a little more closely spaced on the last turn. Umbilical wall marked by rather distantly spaced spiral threads which here render the axial riblets somewhat serrulate. Peristome double, the outer broadly expanded, marked by concentric lamellae. Operculum white, multispiral, the inner four-fifths of the whorls covered with a heavy callus, which is laid down in a somewhat fluted manner, the thickenings curved retractively.

The animal of $C$. (C.) segregatum is flesh-color with a smoky suffusion, the tip of the snout a little paler than the rest. Tentacles smoky gray, a little paler at the tip. Sole of foot flesh-color with pale smoky suffusion. The sole of the foot is medially longitudinally cleft, the locomotory waves being alternate.

The subspecies of this species are widely scattered among mogotes lying east and south of the Organ Mountains and about or west of the road that leads from Pinar del Rio to Vinales. The exception to this is $C$. $(C$. $)$ segregatum sporadicum from Mogote Quilla, Finca el Descanso, Entronque de Herradura, which, in spite of its distance from $C$. $(C$.) segregatum segregatum from the mogotes at Kilometer 14 , is quite similar to this.

This species is distinguished from the other small forms by its strongly banded colored pattern and by the exceedingly strongly developed lamellar ribs, which give the shell a rough surface.

Distribution of the subspecies of $C$. $(C$.$) segregatum is shown in$ figure 79 .

\section{KEY TO THE SUBSPECIES OF CHONDROPOMETES (CHONDROTHYROMA) SEGREGATUM}

Greater diameter more than $16 \mathrm{~mm}$.

Spiral bands strong felipense

Spiral bands not strong.

Spiral bands feeble.

Greater diameter more than $19 \mathrm{~mm}$.

lagunitasense

Greater diameter less than $17 \mathrm{~mm}$ arangoi

Spiral bands absent vallei

Greater diameter less than $15 \mathrm{~mm}$.

Spiral markings strong laureani

Spiral markings not strong, sometimes absent.

Umbilicus rather broad. segregatum

Umbilicus rather narrow.

Shell yellow sporadicum

Shell white mameyi 
CHONDROPOMETES (CHONDROTHYROMA) SEGREGATUM FELIPENSE, new subspecies

Plate 12, Figure 2

This is a medium-sized thin-shelled race. It is of pale buff ground color, with the peristome much paler. The whorls and base are conspicuously marked with almost continuous dark brown spiral bands.

Our shells come from a small mogote $1 / 2$ kilometer west of Kilometer 14 .

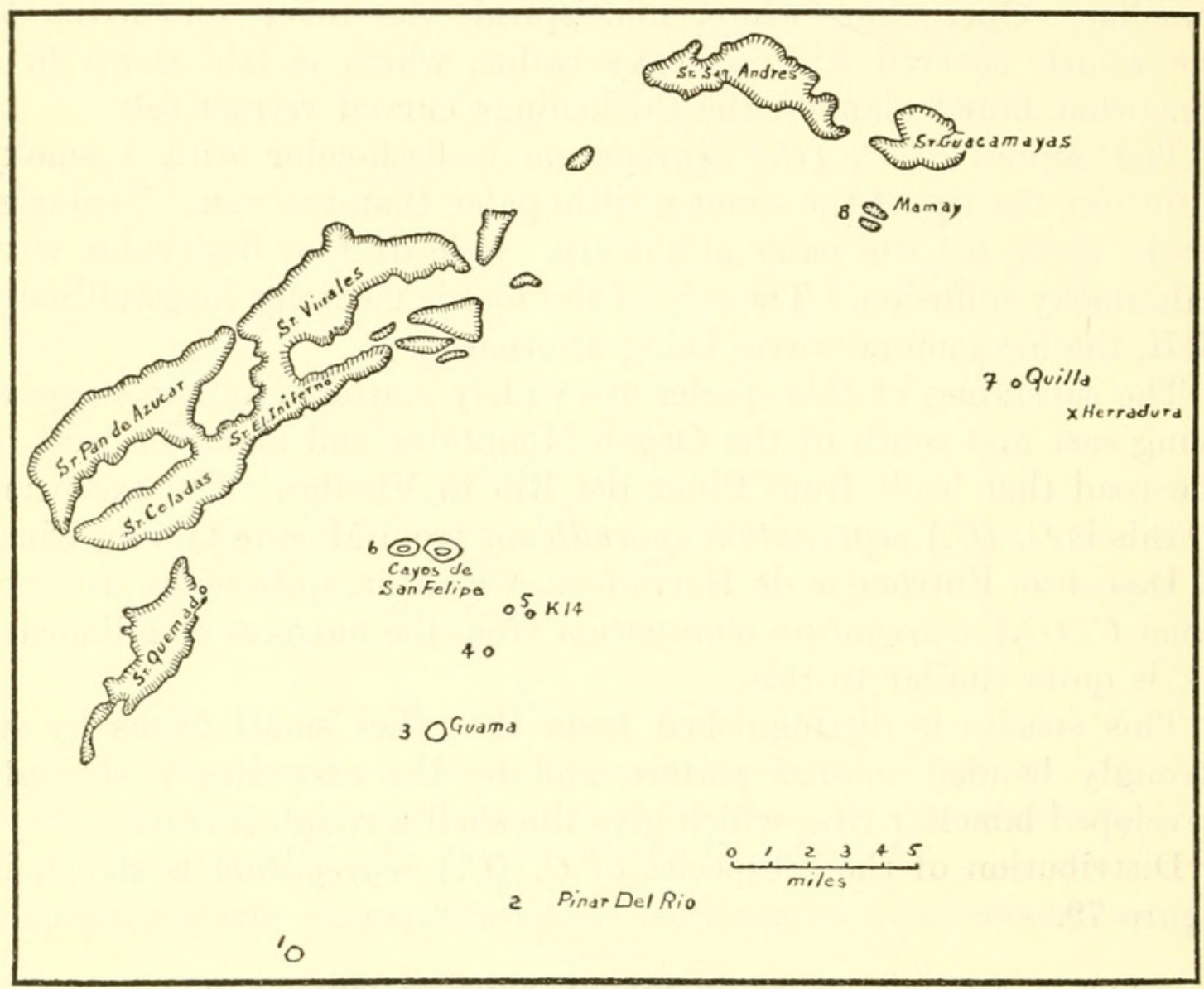

Figure 79.-Distribution of the subspecies of Chrondropometes (Chondrothyroma) segregatum: (1) lagunitasense; (2) laureani; (3) arangoi; (4) vallei; (5) segregatum; (6) felipense; (7) sporadicum; (8) mameyi.

The type, U.S.N.M. no. 468725, an almost complete specimen, has 5.2 whorls remaining and measures: Length, $19.7 \mathrm{~mm}$; greater diameter, $17.3 \mathrm{~mm}$; lesser diameter, $12.6 \mathrm{~mm}$.

The strong spiral color bands distinguish this from the other larger subspecies. Bartsch collected a dead specimen on Cayo San Felipe, which seems indistinguishable from this race.

CHONDROPOMETES (CHONDROTHYROMA) SEGREGATUM LAGUNITASENSE, new subspecies

Plate 12, Figure 3

Shell buff with broad, decidedly interrupted spiral zones of brown. Some of these marks are wider than the spaces that separate them. Peristome pale buff. 
The type, U.S.N.M. no. 367739, was collected by Arango at Los Lagunitas. It has 3.8 whorls remaining and measures: Length, 19.7 $\mathrm{mm}$; greater diameter, $19.7 \mathrm{~mm}$; lesser diameter, $13.7 \mathrm{~mm}$.

CHONDROPOMETES (CHONDROTHYROMA) SEGREGATUM ARANGOI, new subspecies

Plate 12, Figure 9

Shell pale buff, the early turns with a reddish tinge, marked with inconspicuous, rather narrow, interrupted spiral bands of brown. These spiral markings are also arranged in axial series. Peristome white.

The type, U.S.N.M. no. 367746, a complete specimen, was collected by Arango at Hoyo Guama. It has 6.4 whorls and measures: Length, $20.3 \mathrm{~mm}$; greater diameter, $16.2 \mathrm{~mm}$; lesser diameter, $10.7 \mathrm{~mm}$.

The more conic outline and pale color distinguish this readily from the others of the larger races.

CHONDROPOMETES (CHONDROTHYROMA) SEGREGATUM VALLEI, new subspecies

Plate 12, Figure 1

Shell white, unicolor, with the peristome white. Umbilicus with conspicuous spiral threads.

The type, U.S.N.M. no. 428800, was collected by Bartsch and Valle in 1928 on the tall mogote about one and one-half miles southwest of Kilometer 14 between Pinar del Rio and Vinales. It has 4.1 whorls remaining and measures: Length, 19.8; greater diameter, 19.0 $\mathrm{mm}$; lesser diameter, $13.4 \mathrm{~mm}$.

CHONDROPOMETES (CHONDROTHYROMA) SEGREGATUM LAUREANI, new subspecies

Plate 12, Figure 6

Shell small, buff, with white peristome. The conspicuous interrupted brown bands have the elements composing them also arranged in axial series. These are so broad that their arrangement almost produces axial bands; in fact they appear more as axial bands than spiral ones.

This race comes from Mogote de la Caja west of Pinar del Rio.

The type, U.S.N.M. no. 468726, has 3.5 whorls remaining and measures: Length, $14.9 \mathrm{~mm}$; greater diameter, $12.7 \mathrm{~mm}$; lesser diameter, $9.0 \mathrm{~mm}$.

The strong spiral and axial arrangements of the color bands readily distinguish this from the other small races of $C$. $(C$.) segregatum. 
Shell small, rather broadly umbilicated, straw-color, marked by faint interrupted spiral bands of brown; peristome pale yellowish.

The type, U.S.N.M. no. 355037, was collected on the Tomas Barrera Expedition on the mogote on the east side of Kilometer 14, between Pinar del Rio and Vinales. It is a complete specimen having 6 whorls and measures: Length, $15.6 \mathrm{~mm}$; greater diameter, 12.7 $\mathrm{mm}$; lesser diameter $9.6 \mathrm{~mm}$.

This subspecies we also collected on the whole complex of mogotes nestling about Kilometer 14, but although we kept the shells collected on the various rock piles distinct, careful examination does not reveal any distinguishing characters. We are therefore applying this name to the entire lot. This subspecies resembles $C$. $(C$.) segregatum sporadicum mostly but has a heavier shell and wider umbilicus.

CHONDROPOMETES (CHONDROTHYROMA) SEGREGATUM SPORADICUM, new subspecies

Plate 12, Figure 5

Shell small, very thin, of pale buff ground color with the peristome a little paler in color, or feebly marked with rather distantly spaced, interrupted spiral bands of brown.

The type, U.S.N.M. no. 468727, comes from Mogote de Quilla, Finca el Descanso, Entronque de Herradura. It is a complete specimen having 5 whorls and measures: Length, $14.0 \mathrm{~mm}$; greater diameter, $12.0 \mathrm{~mm}$; lesser diameter, $6.3 \mathrm{~mm}$.

The thinner shell and narrower umbilicus distinguish this from $C$. (C.) segregatum segregatum.

\section{CHONDROPOMETES (CHONDROTHYROMA) SEGREGATUM MAMEYI, new subspecies}

Plate 12, Figure 8

Shell similar to $C$. $(C$.) segregatum sporadicum but white with a mere flush of yellow. As in that race, the shell may or may not have pale brown interrupted spiral lines arranged in axial series on spire and base. The axial ribbing in this is also a little stronger, which is also true of the obsolete spiral sculpture.

This subspecies was collected by Natenson on Mogote Mamey, the northern one of the two large limestone peaks off the southwestern end of the Sierra Guacamayas.

The type, U.S.N.M. no. 468928, a complete specimen, has 6.0 whorls and measures: Length, $15.4 \mathrm{~mm}$; greater diameter, $12.7 \mathrm{~mm}$; lesser diameter, $8.9 \mathrm{~mm}$. 


\section{CHONDROPOMETES (CHONDROTHYROMA) SCOPULORUM, new species}

Shell small, unicolor, white or yellowish white Operculum white or pale reddish. Nuclear whorls about 2, very finely granulose, strongly inflated and rounded, continuing the outline of the rest of the spire. Postnuclear whorls inflated, strongly rounded, separated by a well-impressed suture, and marked by retractively curved lamellar axial riblets, which are a little more definitely spaced on the early whorls than the later. Umbilicus varying in width in the different races, but always broadly open. Umbilical wall with or without spiral threads. Peristome double; the outer broadly expanded and reflected, the inner only slightly expanded and reflected. Operculum multispiral with a rather thick callus on the inner four-fifths, which is somewhat fluted, the thickening having a retractive slant.

The animal of $C$. $(C$.) scopulorum perplexum was described by Bartsch in the field from specimens collected at Cueva del Indio, Mogote Colorado, near San Diego Banos, Pinar del Rio Province, June 17, 1928, as follows: Animal pale smoky gray; tentacles almost sooty with a subterminal paler band. Snout a little paler than the general coloration of the body: edge of body at foot flesh-color. Sole of foot flesh-color with a faint smoky flush. The internal anatomy shines through the body wall behind the tentacles with a rosy flush. The short foot is longitudinally medially, deeply cleft, in progression; the motion of the two sides is alternate.

This species ranges from the Sierra de Guira, eastward to the Sierra la Cumbre. The Rio San Diego divides the mountains to the east from the mountains to the west. Those to the west of San Diego los Banos harbor $C$. (C.) scopulorum scoputorum, while the mogotes to the east of the Rio San Diego harbor $C$. $(C$.) scoputorum perplexum. The Sierra la Cumbre itself harbors $C$. $(C$.) scopulorum cumbrense.

Distribution of the subspecies of $C$. (C.) scopulorum is shown in figure 80 .

KEY TO THE SUBSPECIES OF CHONDROPOMETES (CHONDROTHYROMA) SCOPULORUM

Spiral threads in umbilicus fairly strong cumbrense Spiral threads in umbilicus obsolete.

Axial ribs closely spaced scopulorum

Axial ribs distantly spaced perplexum

CHONDROPOMETES (CHONDROTHYROMA) SCOPULORUM CUMBRENSE, new subspecies Plate 12, Figure 10

Shell small, yellowish white with the ribs rather distantly spaced and the spiral threads on the umbilicus rather prominent. There 
are also approximations of some of the riblets at irregular intervals, which give the shell a somewhat varicid aspect.

The type, U.S.N.M. no. 367742, was collected by Mr. Henderson on the south side of the west end of Sierra la Cumbre. It is a complete specimen, having 6 whorls, and measures: Length, $18.0 \mathrm{~mm}$; greater diameter, $15.2 \mathrm{~mm}$; lesser diameter, $10.4 \mathrm{~mm}$.

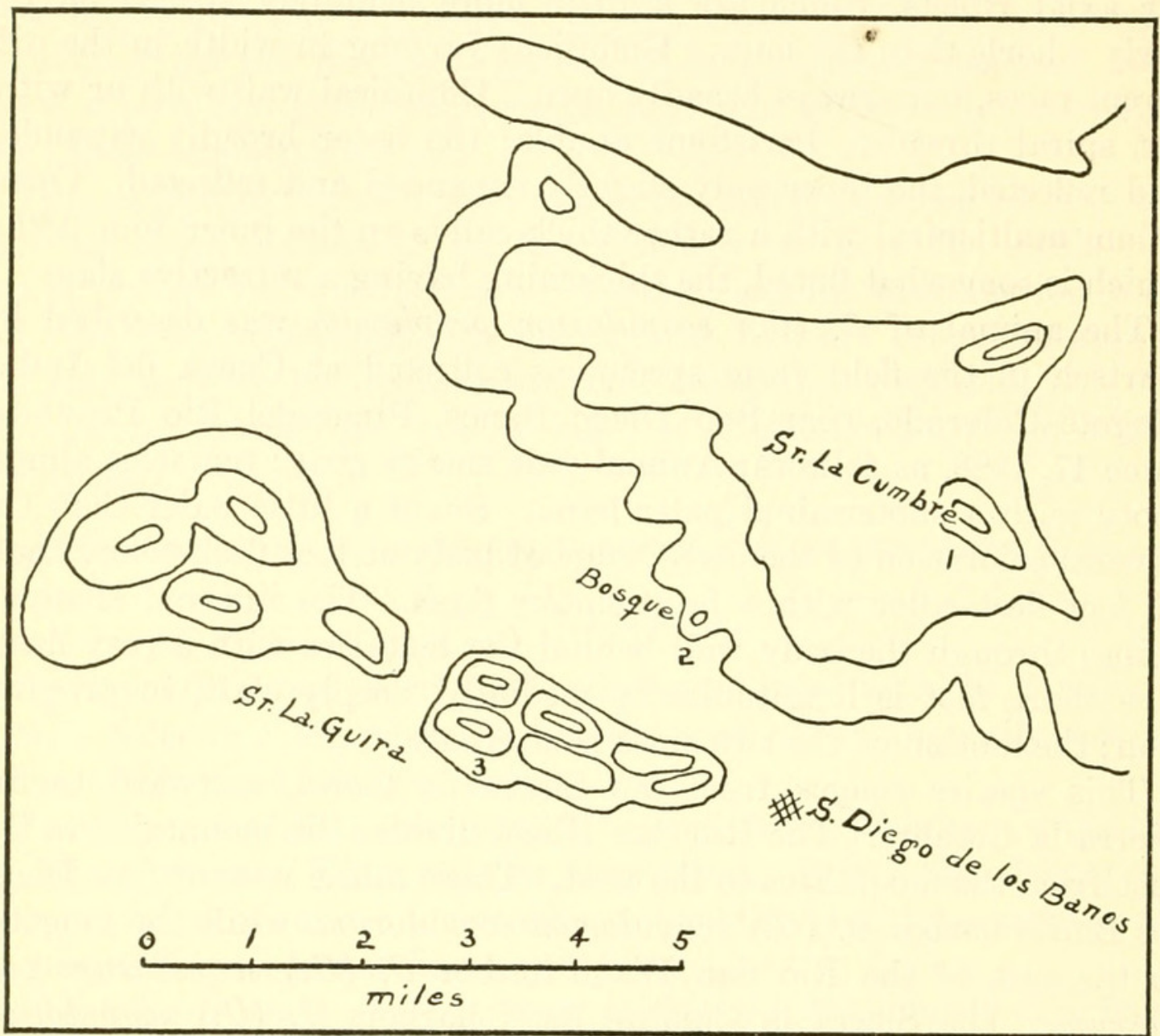

Figure 80.-Distribution of the subspecies of Chondropometes (Chondrothyroma) scopulorum: (1) cumbrense; (2) perplexum; (3) scopulorum.

CHONDROPOMETES (CHONDROTHYROMA) SCOPULORUM SCOPULORUM, nEW subspecies

Plate 12, Figure 11

Shell of medium size, marked by rather closely spaced, decidedly sublamellar axial ribs. Umbilical wall without spiral threads. There is also no delimiting cord at the outer edge of the umbilicus.

The type, U.S.N.M. no. 335034, was collected by Mr. Henderson on the third mogote west of the river and north of San Diego de los Banos. It has 3.5 whorls remaining and measures: Length, $16.6 \mathrm{~mm}$; greater diameter, $15.8 \mathrm{~mm}$; lesser diameter, $11.8 \mathrm{~mm}$.

We have this race from a number of mogotes from the southeastern part of the Sierra la Guira. 
Shell small, white, with the ribs sublamellar, rather closely spaced. Spiral threads in the umbilicus feeble; peristome broadly expanded.

The type, U.S.N.M. no. 367748, was collected by Aguayo and Bermudez on Mogote Colorado near San Diego de los Banos, on the east side of the Rio San Diego. It has 4.1 whorls remaining and measures: Length, $17.9 \mathrm{~mm}$; greater diameter, $16.0 \mathrm{~mm}$; lesser diameter, $11.5 \mathrm{~mm}$.

Specimens of this subspecies have been found without breathing pore. We have also specimens from Mogote Bosque.

\section{CHONDROPOMETES (CHONDROTHYROMA) BELLISIMUM, new species}

Plate 11, Figure 10

Shell rather large, bright red except for the broadly reflected peristome, which is yellowish white. Operculum red. The axial ribs are rather low and closely spaced, the spaces between them on the last whorl being almost as narrow as the ribs. The last half of the last whorl also shows poorly developed spiral threads, which are best developed on the base. The umbilical wall is also marked by conspicuous spiral threads. This species recalls $C$. $(C$. $)$ eximium eximium but can at once be distinguished from that by the absence of the dark axial band immediately behind the peristome, by the much lower and more closely spaced axial ribs, and by its having the spiral striations on the last whorl referred to above.

The type, U.S.N.M. no. 367743, was collected by Arango at Mogote del Bosque de Galalón. It has 4.5 whorls remaining and measures: Length, $19.3 \mathrm{~mm}$; greater diameter, $17.8 \mathrm{~mm}$; lesser diameter, $11.9 \mathrm{~mm}$.

\section{HENDERSONINA, new genus}

Brilliantly colored shells, varying in shape from broadly to narrowly ovate to elongate-turreted. The early nuclear whorls are smooth, the first portion of the first postnuclear whorl showing axial threads that soon develop into axial riblets on the succeeding portions of the shell. Beginning with the last part of the first postnuclear whorl, spiral threads make their appearance, which render the axial riblets nodulose at their junction on the early postnuclear whorl. The axial and spiral sculpture may both become enfeebled beyond the first half of the spire, as in Hendersonina (Hendersonina) hendersoni, or persist quite strongly to the end, as in some of the races of H. (Hendersonida) discolorans and H. (Scobinapoma) scobina. The suture may or may not be crenulated. 
Base umbilicated. Aperture large, almost subquadratic, forming an angle at the junction of the outer lip and parietal wall. Peristome double, the inner only slightly expanded and appressed to the outer, which is expanded in varying degrees in the different species. Breathing pore present in Hendersonina; absent in the other two subgenera. Operculum multispiral with excentric nucleus, the inner four-fifths of the turns covered with a heavy granular deposit which is more or less fluted.

Type: Hendersonina (Hendersonina) hendersoni (Torre).

\section{KEY TO THE SUBGENERA OF GENUS HENDERSONINA}

Shell elongate-turreted; breathing pore present

Hendersonina

Shell ovate; breathing pore absent.

Outer lip broadly expanded.

Hendersonida

Outer lip not broadly expanded.

Scobinapoma

Hendersonina, new subgenus

Shell elongate-turreted, brilliantly varicolored, breathing pore present on the parietal wall near the posterior angle of the aperture.

Type: Hendersonina (Hendersonina) hendersoni (Torre).

\section{HENDERSONINA (HENDERSONINA) HENDERSONI (Torre)}

Plate 13, Figure 13

1909. Chondropoma hendersoni Torre, Nautilus, vol. 23 , pp. 49-50, pl. 4, fig. 6 . 1920. Chondrothyra (Chondrothyra) hendersoni Henderson and Bartsch, Proc. U. S. Nat. Mus., vol. 58, p. 64 .

The elongate-turreted shape and variegated color combined with a breathing pore render this not only a most beautiful but most distinct species found in all Cuba. It is confined to the northeastern end of the Costanera del Abra, occupying the high parts of an extremely limited area.

The type, U.S.N.M. no. 492714, has 5.5 whorls remaining (it has probably lost 4.5 whorls at the tip) and measures: Length, $26.8 \mathrm{~mm}$; greater diameter, $15.4 \mathrm{~mm}$; lesser diameter, $10.6 \mathrm{~mm}$. The other specimen that we figure has lost the first 2 whorls; the 8 remaining measure: Length, $31.6 \mathrm{~mm}$; greater diameter, $15.7 \mathrm{~mm}$; lesser diameter, $11.6 \mathrm{~mm}$.

The animal is very short, ashy gray, and has long, slender, coralred tentacles. The foot is longitudinally medially divided. Locomotion of the two sides alternate.

\section{Hendersonida, new subgenus}

Medium-sized shells of broadly ovate outline, usually brilliantly colored; suture crenulated with a series of tufts, the rest of the whorls 
nodulose at the junction of the axial riblets and spiral threads. All sculpture decidedly reduced on the last whorl. Aperture broadily ovate; peristome double, the outer broadly expanded, less so on the parietal wall, somewhat fluted, marked by feeble concentric threads; the inner narrowly expanded, reflected over and adnate to the outer. Operculum thin, corneus, covered, with a fine granular deposit.

Type: Hendersonina (Hendersonida) discolorans (Wright) Pfeiffer.

\section{HENDERSONINA (HENDERSONIDA) DISCOLORANS (Wright) Pfeiffer}

Shell of medium size, broadly ovate, yellow or of various shades of rose color, sometimes spirally banded; peristome white; operculum horn-color or with rosy flush. Nuclear whorls a little more than 2, well rounded, very minutely granulose, the last portion of the last turn with a few feeble axial threads. Postnuclear whorls inflated, well rounded, marked by weak axial and spiral threads, which on the early whorls form slightly cusplike tubercles at their junction. Suture deeply impressed, marked by irregularly developed and distributed tufts on the summits of the whorls. Periphery and base of the last whorl inflated, strongly rounded, the latter openly umbilicated and marked by feeble axial and spiral threads. The last whorl may or may not be solute for a fraction of a turn.

The known range of this species extends through the Laguna Piedras northward to the Sierra San Andrés and east to Mogote Fonte.

We are recognizing three subspecies, which the adjoining key will help to identify:

Distribution of the subspecies of $H$. (H.) discolorans is shown in figure 81 .

KEY TO THE SUBSPECIES OF HENDERSONINA (HENDERSONIDA) DISCOLORANS

Shell rose-color.

Base not darker than the rest of the last whorl discolorans

Base darker than the rest of the last whorl________________-_ bicolor Shell yellow decolor

\section{HENDERSONINA (HENDERSONIDA) DISCOLORANS DISCOLORANS (Wright) Pfeiffer}

\section{Plate 13, Figure 9}

1863. Chondropoma discolorans (Wright) PfenfFer, Malakozool. Blätter, vol. 10, p. 189.

This subspecies, whose base is colored like the rest of the last whorl, comes from the mogotes scattered through the Laguna Piedras from Puertecitas north to Mogote La Jagua de San Antonio. While it shows considerable diversity through this range, the variables are 
not fixed for isolated mogotes but appear to be present in each of them, that is, definite subspecific characters associated with definite mogotes are not present.

The specimen figured, U.S.N.M. no. 367761, comes from Mogote Capon. It has lost most of the nuclear turns; the 5 whorls remaining measure: Length, $20.3 \mathrm{~mm}$; greater diameter, $13.4 \mathrm{~mm}$; lesser diameter, $10.0 \mathrm{~mm}$.

\section{HENDERSONINA (HENDERSONIDA) DISCOLORANS BICOLOR, new subspecies}

Plate 13, Figure 10

Shell averaging smaller than $H$. (H.) discolorans discolorans and having the last whorl much oftener adnate than that subspecies. The base in this is also always darker than the rest of the last whorl.

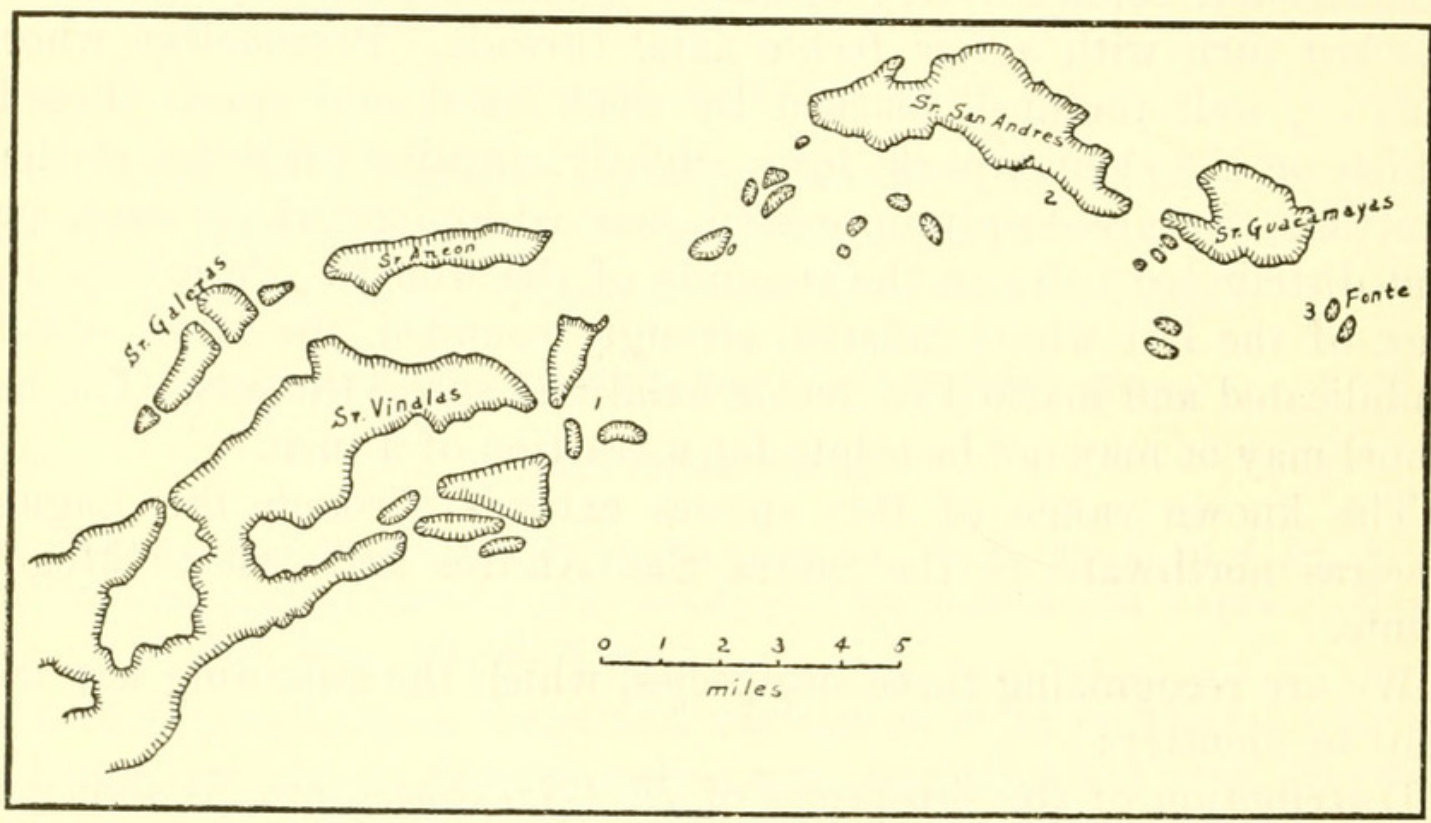

FIGURE 81,-Distribution of the subspecies of Hendersonina (Hendersonida) discolorans: (1) discolorans; (2) bicolor; (3) decolor.

The type, U.S.N.M. no. 492715, comes from the south side of the Sierra San Andrés. It has 5 whorls remaining and measures: Length, $17.0 \mathrm{~mm}$; greater diameter, $11.8 \mathrm{~mm}$; lesser diameter, $8.3 \mathrm{~mm}$.

This subspecies we know from the south side of the Sierra San Andrés and some of the mogotes to the south and southeast of this range.

HENDERSONINA (HENDERSONIDA) DISCOLORANS DECOLOR, new subspecies

Plate 13, Figure 8

A large series of specimens from the Mogote de Fonte, southeast of the Sierra Guacamayas look as if they were partial albinos; they are uniformly pale yellow with white peristome. They are also smaller than the other two races. The extreme tip has a dark spot. 
The type, U.S.N.M. no. 492716, the only complete specimen that we have seen in all the material examined of all the races, has 6.0 whorls and measures: Length, $16.3 \mathrm{~mm}$; greater diameter, $11.2 \mathrm{~mm}$; lesser diameter, $8.2 \mathrm{~mm}$.

\section{SCOBINAPOMA, new subgenus}

Very small Hendersonina of ovate shape with filelike sculpture on the postnuclear whorls. Aperture very broadly ovate; peristome double; outer and inner almost equal in expansion and reflection, which is slight.

Type: Hendersonina (Scobinapoma) scobina (Gundlach) Pfeiffer.

Three species are known in this subgenus, which the following key will help to differentiate:

Distribution of the species and subspecies of Scobinapoma is shown in figure 82 .

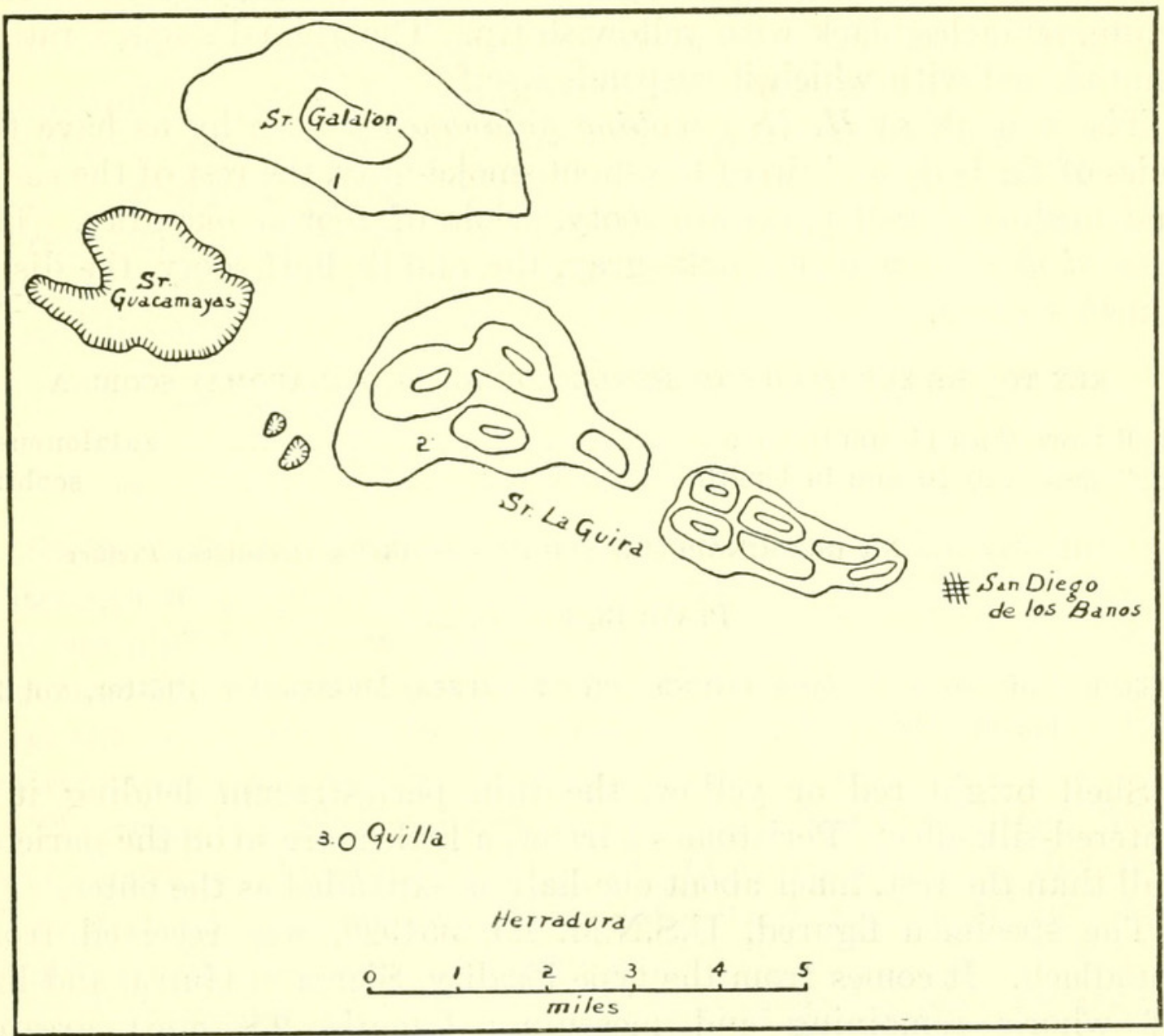

Figure 82.-Distribution of the species and subspecies of subgenus Scobinapoma: (1) H. (S.) scobina galalonensis; (2) scobina scobina and cirrata; (3) maculata.

\section{KEY TO THE SPECIES OF SUBGENUS SCOBINAPOMA}

Outer lip of same color as rest of shell scobina

Outer lip not same color as rest of shell.

Outer lip spotted.

Last whorl interruptediy banded maculata

Last whorl not interruptedly banded. cirrata 
Shell quite small, ovate, red or pale yellow, usually with a thin periostracum, which gives the surface a watered-silk effect. Nuclear whorls about 2 , microscopically granulose, the last portion showing a few hairlike incremental lines. Postnuclear whorls with fine tubercles which lend the surface a filelike aspect. The last whorl is always solute and somewhat descending near the end. Base well rounded, narrowly openly umbilicated. Aperture broadly oval, almost subcircular, angulated posteriorly. The peristome is double, the outer narrowly expanded and reflected, the inner only slightly smaller, also reflected and adnate to the outer. Operculum thin, covered with a finely granular deposit.

Of the animal of $H$. (S.) scobina, Gundlach says that it is brownish with small flecks of white on all of the foot. Head, with the exception of the snout, blackish. Eye ring and base of tentacles clay-yellowishwhite, tentacles black with yellowish tip. The animal spins a rather long thread with which it suspends itself.

The animals of $H$. (S.) scobina galanonensis seen by us have the sides of the body and tip of the snout smoke-gray, the rest of the snout and median dorsal parts are sooty. Sole of foot smoke-gray. The base of the tentacles is smoke-gray, the middle half sooty, the distal fourth orange.

KEY TO THE SUBSPECIES OF HENDERSONINA (SCOBINAPOMA) SCOBINA

Shell more than $11 \mathrm{~mm}$ in length galalonensis Shell less than $10 \mathrm{~mm}$ in length scobina

\section{HENDERSONINA (SCOBINAPOMA) SCOBINA SCOBINA (Gundlach) Pfeiffer}

Plate 13, Figure 12

1863. Chondropoma scobina (Gundlaoh) Pfeiffer, Malakozool. Blätter, vol 10, pp. 189-190.

Shell bright red or yellow, the thin periostracum lending it a watered-silk effect Peristomes narrow, a little more so on the parietal wall than the rest, inner about one-half as expanded as the outer.

The specimen figured, U.S.N.M. no. 354929, was received from Gundlach. It comes from the type locality, Sierra la Guira, and has 4.6 whorls remaining and measures: Length, $9.8 \mathrm{~mm}$; greater diameter, $6.7 \mathrm{~mm}$; lesser diameter, $5.4 \mathrm{~mm}$.

This subspecies is very similar to $H$. (S.) scobina galalonensis, from which its much smaller size will at once distinguish it. 
HENDERSONINA (SCOBINAPOMA) SCOBINA GALALONENSIS, new subspecies

Plate 13, Figure 14

Shell similar to $H$. (S.) scobina scobina but much larger; only red forms have so far been seen. This race comes from the Sierra de Galalon.

The type, U.S.N.M. no. 367762, was collected by Arango. It has 4.7 whorls remaining and measures: Length, $11.3 \mathrm{~mm}$; greater diameter, $7.6 \mathrm{~mm}$; lesser diameter, $6.3 \mathrm{~mm}$.

HENDERSONINA (SCOBINAPOMA) CIRRATA (Wright) Pfeiffer

Plate 13, Figure 4

1867. Cyclostoma (Chomdropoma) cirratum (Wright) PFeIfFer, Malakozool. Blätter, vol. 14, pp. 210-211.

Shell quite small, ovate, flesh-colored with the plugged part of the first of the remaining whorls blackish brown and with the outer lip interruptedly purplish chocolate-brown. Peristome very narrow, a little wider on the outer lip than on the columellar and parietal walls.

The specimen figured, U.S.N.M. no. 25095, was received from Wright and is a topotype from the Sierra la Guira. It has 4 whorls remaining and measures: Length, $8.3 \mathrm{~mm}$; greater diameter, $5.8 \mathrm{~mm}$; lesser diameter, $4.1 \mathrm{~mm}$.

\section{HENDERSONINA (SCOBINAPOMA) MACULATA, new species}

Plate 13, Figure 11

Shell small, flesh-color, with a greenish tinge, marked by 3 broad, interrupted spiral bands of chestnut-brown between the summit and the periphery of the last whorl and two additional ones of the same strength and coloration on the base. The cusping is less strong and less numerous than in the other two species, that is, there are fewer spiral threads and axial riblets.

The type, U.S.N.M. no. 492717 , a complete specimen, has 6 whorls and measures: Length, $9.4 \mathrm{~mm}$; greater diameter, $5.7 \mathrm{~mm}$; lesser diameter, $4.5 \mathrm{~mm}$. It comes from Mogote de Quilla (Canas Alta) southwest of Entronque de Herradura.

In this species the body of the animal is smoky gray tending toward sooty on the posterior half of the snout and the median line between the tentacles. The sides are a little darker than the rest of the upper surface. The sides are marked with innumerable fine white dots. Tentacles gently tapering until the distal third, from there on swollen, yellowish on the basal half, smoke-gray on the rest, but with the sides of the swollen distal third sooty. The internal anatomy 
shines through the integument of the animal as a rosy flush behind the tentacles. Sole of foot smoke-gray, medially longitudinally cleft; locomotion of the two sides alternate.

The animal at rest usually suspends itself by a mucous thread.

\section{TURRITHYRA, new genus}

Shell large, elongate-turreted, unicolor, axially or spirally banded, or both, with axial and spiral riblets and threads whose junction may or may not form tubercles or short spines. Sutures minutely tufted. Aperture large, broadly oval or subcircular; peristome double, expanded to a varying degree in the different species. A breathing pore may or may not be present.

Type: Turrithyra (Turrithyra) canaliculata (Gundlach) Pfeiffer.

This genus is readily divisible into three subgenera, as indicated by the following key:

\section{KEY TO THE SUBGENERA OF TURRITHYRA}

Breathing pore present.

Inner lip cut, posterior half reflected over umbilicus Turrithyretes

Inner lip not cut, posterior half not reflected over umbilicus Turrithyra Breathing pore absent Turripoma

TURRITHYRETES, new subgenus

Those Turrithyras that possess a breathing pore and have the inner lip cut with the posterior half reflected over the umbilicus. Type: Turrithyra (Turrithyretes) sinuosa (Wright) Pfeiffer.

KEY TO THE SPECIES OF SUBGENUS TURRITHYRETES

Shell strongly echinulate echinulata Shell not strongly echinulate sinuosa

\section{TURRITHYRA (TURRITHYRETES) ECHINUlAta (Wright) Pfeiffer}

Shell red or reddish, unicolor or spirally banded, with the peristome white or pale yellow. Nuclear whorls decollated in all our specimens. Postnuclear whorls inflated, well rounded, marked by slender, retractively slanting axial and spiral threads, the junction of which forms strong spines or cusps whose tips are retractively curved. These cusps continue undiminished over the last whorl and its base. Peristome double, the outer broadly expanded and reflected, radially fluted and marked with incremental lines. That of the posterior half of the inner lip is reflected over and covers the umbilicus. The inner peristome is less extensive, it is also reflected and adnate to the outer.

The exact type locality of the typical race is unknown. "Vignales," the locality given, is a rather broad designation as we now understand it. The lesser race comes from the Sierra del Abra. 
KEY TO THE SUBSPECIES OF TURRITHYRA (TURRITHYRETES) ECHINULATA

Greater diameter more than $12 \mathrm{~mm}$ echinulata Greater diameter less than $10 \mathrm{~mm}$ echinella

TURRITHYRA (TURRITHYRETES) ECHINULATA ECHINULATA (Wright) Pfeiffer

Plate 14, Figure 11

1863. Chondropoma echinulatum (Wright) Pfeiffer, Malakozool. Blätter, vol. 10, pp. 184-185.

1920. Chondrothyra (Chondrothyretes) echinulata Henderson and Bartsch, Proc. U. S. Nat. Mus., vol. 58, p. 64.

This race, which Pfeiffer says Wright found under decaying leaves at "Vignales," has so far not been rediscovered by any subsequent collectors. It is abundantly represented in many collections but always dating back to Wright's collecting.

The shells are usually dark red, though at times paler individuals are present. Spiral color bands if present are scarcely noticeable. The shells are larger than those of the next subspecies.

The specimen figured, U.S.N.M. no. 10970, one of four, has 5.3 whorls remaining, and measures: Length, $21.1 \mathrm{~mm}$; greater diameter, $12.8 \mathrm{~mm}$; lesser diameter, $8.3 \mathrm{~mm}$.

\section{TURRITHYRA (TURRITHYRETES) ECHINULATA ECHINELLA, new subspecies}

\section{Plate 14, Figure 10}

This race was collected in the Sierra del Abra, 6 miles west of the River Cejanal in front of Enrique Veles's place, where it is found on bushes.

It is usually paler, with the spaces between the spiral cords darker than the cords and their spines. It is smaller than typical $T$. (T.) echinulata echinulata.

The type, U.S.N.M. no. 468683 , has 4.9 whorls remaining and measures: Length, $17.7 \mathrm{~mm}$; greater diameter, $9.0 \mathrm{~mm}$; lesser diameter, $7.2 \mathrm{~mm}$.

\section{TURRITHYRA (TURRITHYRETES) SINUOSA (Wright) Pfeiffer}

Shell elongate-turreted, varying in color from white through pale yellow, through buff to reddish in ground color, unicolor or interruptedly spirally banded; peristome white or pale yellowish buff. Nuclear whorls about 2, inflated and strongly rounded, smooth except the last part of the last turn, which shows a few incremental lines. Postnuclear whorls also inflated and strongly rounded, separated by a well-constricted suture and marked by fairly regularly developed and spaced, retractively slanting, threadlike axial riblets crossed by $66879-38-4$ 
equal or heavier spiral threads, which are also of fairly regular spacing. The junctions of the axial and spiral threads form small rounded tubercles, some of which near the upper parts of the turns tend toward cusps. This sculpture also characterizes the inflated and well-rounded base, being even stronger here than on the spire. The base is openly umbilicated, the umbilical wall being sculptured like the adjacent area. Aperture large, very broadly ovate, with a slight angulation at the posterior angle. Peristome double, the outer broadly flaringly expanded, radially fluted and marked with concentric incremental lines, cut in the middle of the columellar side and having the posterior half reflected to partially cover the umbilicus; there is usually also a flexure in that of the outer lip a little anterior to the posterior angle, giving this part a somewhat channeled effect. The inner peristome is of much lesser extent; it is also reflected and adnate to the outer. Operculum thin, corneous, covered with a thin granular deposit.

The races of this species cluster about the road leading through the Puerta de la Ancon.

Distribution of the subspecies of $T$. (T.) sinuosa is shown in figure 83.

KEY TO THE SUBSPECIES OF TURRITHYRA (TURRITHYRETES) SINUOSA

Shell of red or reddish ground color vicina

Shell not of red or reddish ground color.

Shell of pale buff or white ground color.

Interrupted spiral bands conspicuous.

Axial and spiral threads numerous and crowded hutia

Axial and spiral threads less numerous and less crowded.

Greater diameter more than $13 \mathrm{~mm}$ sinuosa Greater diameter less than $12 \mathrm{~mm}$ opposita Interrupted spiral bands inconspicuous or absent rhachitica

TURRITHYRA (TURRITHYRETES) SINUOSA VICINA, new subspecies

Plate 14, Figure 13

This race comes from the Sierra San Vicente and the Sierra Vinales where it joins the Sierra Vicente. It is particularly abundant on the walls of the Ensenada Delicia. It is a large subspecies of almost always red or reddish ground color with conspicuous slender interrupted spiral bands of brown. Peristome white, sometimes buff or even pale orange.

The type, U.S.N.M. no. 492724, comes from the Sierra Vinales; it has 5.5 whorls remaining and measures: Length, $26.0 \mathrm{~mm}$; greater diameter, $15.8 \mathrm{~mm}$; lesser diameter, $10.8 \mathrm{~mm}$.

The red or reddish color is quite characteristic of this subspecies. 
TURRITHYRA (TURRITHYRETES) SINUOSA HUTIA, new subspecies

Plate 14, Figure 12

This subspecies, which Bartsch collected on Mogote Hutia, a limestone block on the east side of the center part of the Sierra de la Chorrera, differs from $T$. (T.) sinuosa opposita in having more and closer spaced spiral threads.

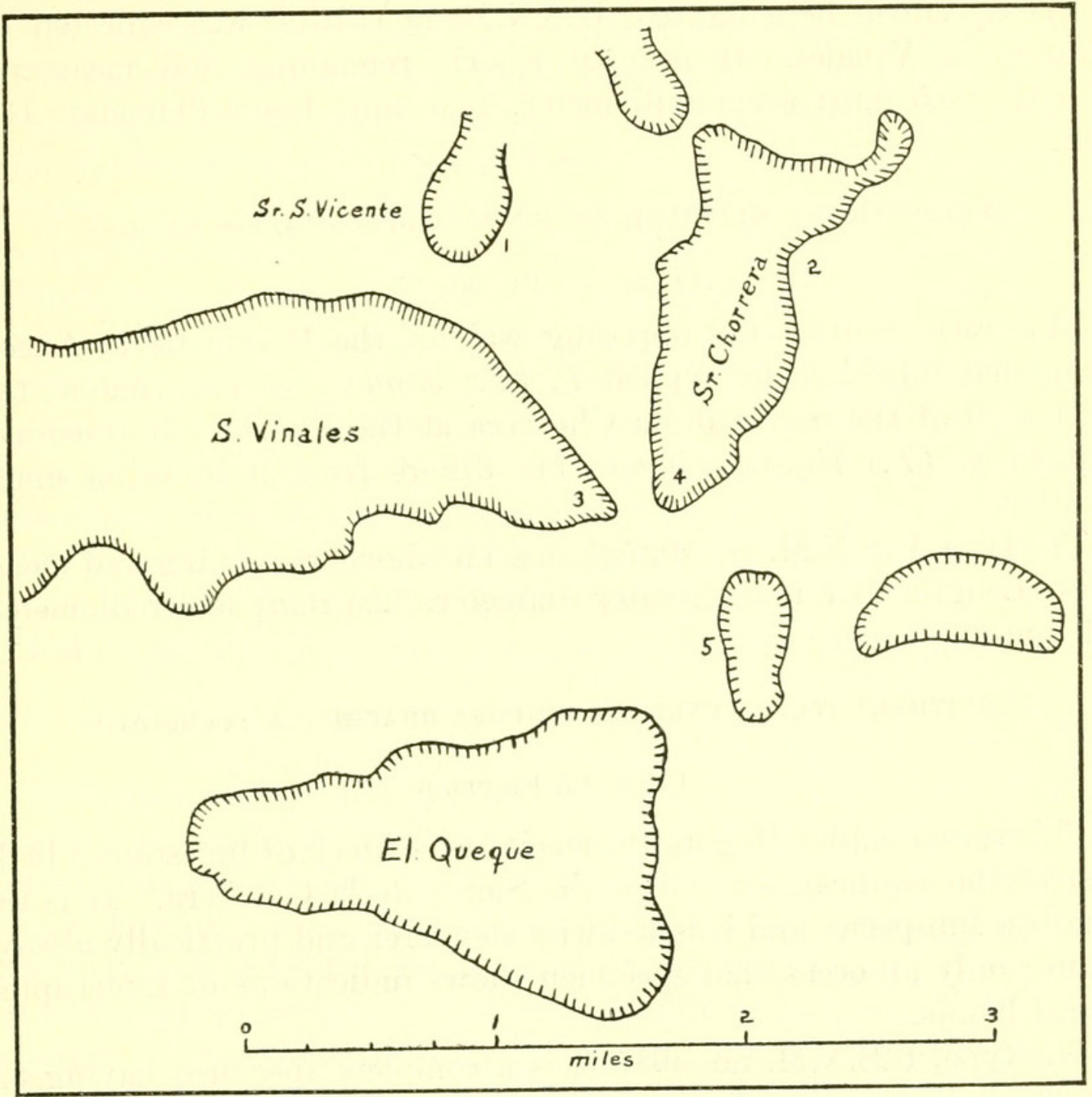

FIgure 83. Distribution of the subspecies of Turrithyra (Turrithyretes) sinuosa: (1) vicina; (2) hutia; (3) sinuosa; (4) opposita; (5) rhachitica.

The type, U.S.N.M. no. 468732, has 4.5 whorls remaining and measures: Length, $18.8 \mathrm{~mm}$; greater diameter, $11.0 \mathrm{~mm}$; lesser diameter, $7.9 \mathrm{~mm}$.

\section{TURRITHYRA (TURRITHYRETES) SINUOSA SINUOSA (Wright) Pfeiffer}

Plate 14, Figure 16

1862. Chondropoma sinuosa (Wright) Pfeiffer, Malakozool. Blätter, vol. 10, p. 185.

1864. Chondropoma sinuosa Pfeiffer, Novitates conchologicae, vol. 1, p. 242, pl. 62, figs. $10,11$. 
1920. Chondrothyra (Chondrothyretes) simuosa Henderson and Bartsch, Proc. U. S. Nat. Mus., vol. 58 , p. 64.

Pfeiffer, in his Novitates conchologicae, plainly figures the large shell of pale ground color with conspicuous interrupted dark bands, which occupies the west side of the Puerta de la Ancon. We have here collected hundreds of specimens that in every way agree with Pfeiffer's description and figure.

The specimen here figured, U.S.N.M. no. 57614, was collected by Arango at Vinales. It has 5.0 whorls remaining and measures: Length, $25.5 \mathrm{~mm}$; greater diameter, $14.5 \mathrm{~mm}$; lesser diameter, 11.0 $\mathrm{mm}$.

TURRITHYRA (TURRITHYRETES) SINUOSA OPPOSITA, new subspecies

Plate 14, Figure 15

This race occupies the opposing wall of the Puerta de la Ancon from that inhabited by typical $T$. (T.) sinuosa sinuosa, that is, the west wall of the Sierra de la Chorrera at the Puerta. It resembles typical T. (T.) sinuosa sinuosa but differs from it in being much smaller.

The type, U.S.N.M. no. 492723 , has 4.6 whorls remaining and measures: Length, $21.7 \mathrm{~mm}$; greater diameter, $12.0 \mathrm{~mm}$; lesser diameter, $8.4 \mathrm{~mm}$.

\section{TURRITHYRA (TURRITHYRETES) SINUOSA RHACHITICA, new subspecies}

Plate 14, Figure 6

This race occupies Mogote Puertecitas, the block of limestone a little east of the southeastern end of the Sierra de la Chorrera. It is the smallest subspecies and it is likewise slenderer and practically always white; only an occasional specimen shows indications of interrupted spiral bands.

The type, U.S.N.M. no. 468733, is a complete specimen having 8.5 whorls and measures: Length, $21.3 \mathrm{~mm}$; greater diameter, $8.5 \mathrm{~mm}$; lesser diameter, $7.0 \mathrm{~mm}$.

\section{TURRITHYRA, new subgenus}

Those Turrithyras that possess a breathing pore and have the reflected inner lip uncut.

Type: Turrithyra (Turrithyra) canaliculata (Gundlach) Pfeiffer.

KEY TO THE SPECIES OF SUBGENUS TURRITHYRA

Outer peristome broadly expanded.

Axial sculpture threadlike.

Spiral sculpture stronger than the axial mendax

Spiral sculpture not stronger than the axial canaliculata 
Axial sculpture sublamellar. deceptor Outer peristome not broadly expanded. hamlini

TURRITHYRA (TURRITHYRA) MENDAX, new species

Plate 14, Figure 14

Shell elongate-turreted, white or yellow. Postnuclear whorls somewhat inflated, strongly rounded, marked by numerous retractively curved, slender, threadlike axial ribs, which extend undiminished across the periphery and base of the last whorl. The spiral sculpture consists also of slender threads, which are a little stronger than the axial; the combination of these elements lends the surface a fenestrated pattern. In the moderately open umbilicus the spiral threads are even stronger than those of the spire. Suture strongly constricted. Base inflated, well rounded. Aperture very broadly ovate; peristome double, the outer very broadly expanded and reflected, radially fluted and marked by concentric lines of growth; the inner only moderately expanded and reflected and adnate to the outer. Breathing pore at the posterior angle. Operculum thin, with a rather heavy deposit of granules which lend it a retractively fluted aspect.

The type, U.S.N.M. no. 468728, comes from the Cafetal de la Penitencia, Vinales. It has 4.5 whorls remaining and measures: Length, $21.4 \mathrm{~mm}$; greater diameter, $12.5 \mathrm{~mm}$; lesser diameter, $8.8 \mathrm{~mm}$.

\section{TURRITHYRA (TURRITHYRA) CANALICUlata (Gundlach) Pfeiffer}

Shell elongate-turreted, red or reddish, with or without darker axial streaks and conspicuous or inconspicuous interrupted spiral bands of brown. Nuclear whorls smooth, excepting the last part of the last turn, which shows a few strong incremental lines. Postnuclear whorls inflated, strongly rounded, and marked by threadlike axial riblets and a little finer spiral threads, except on the umbilicus, where they are much stronger. The axial threads pass over the inflated, well-rounded periphery and base into the open umbilicus. Suture well constricted. Aperture broadly ovate; peristome double, the outer broadly expanded, somewhat auriculated at the posterior angle, radially fluted and marked by concentric lines of growth; the inner less widely expanded, reflected and adnate to the outer. Breathing pore on the parietal wall near the posterior angle of the aperture. Operculum covered on the inner two-thirds of its turn with a heavy granular, calcareous deposit in a retractively fluted pattern.

This species has several races, all of which cluster about Pan de Guajaibon.

Distribution of the subspecies of $T$. (T.) canaliculata is shown in figure 84 . 
KEY TO THE SUBSPECIES OF TURRITHYRA (TURRITHYRA) CANALICULATA

Shell with conspicuous axial brown streaks pinalillensis

Shell without conspicuous axial brown streaks.

Interrupted spiral brown bands conspicuous.

Axial riblets rather strong andreas

Axial riblets feeble saguaensis

Interrupted spiral brown bands inconspicuous canaliculata
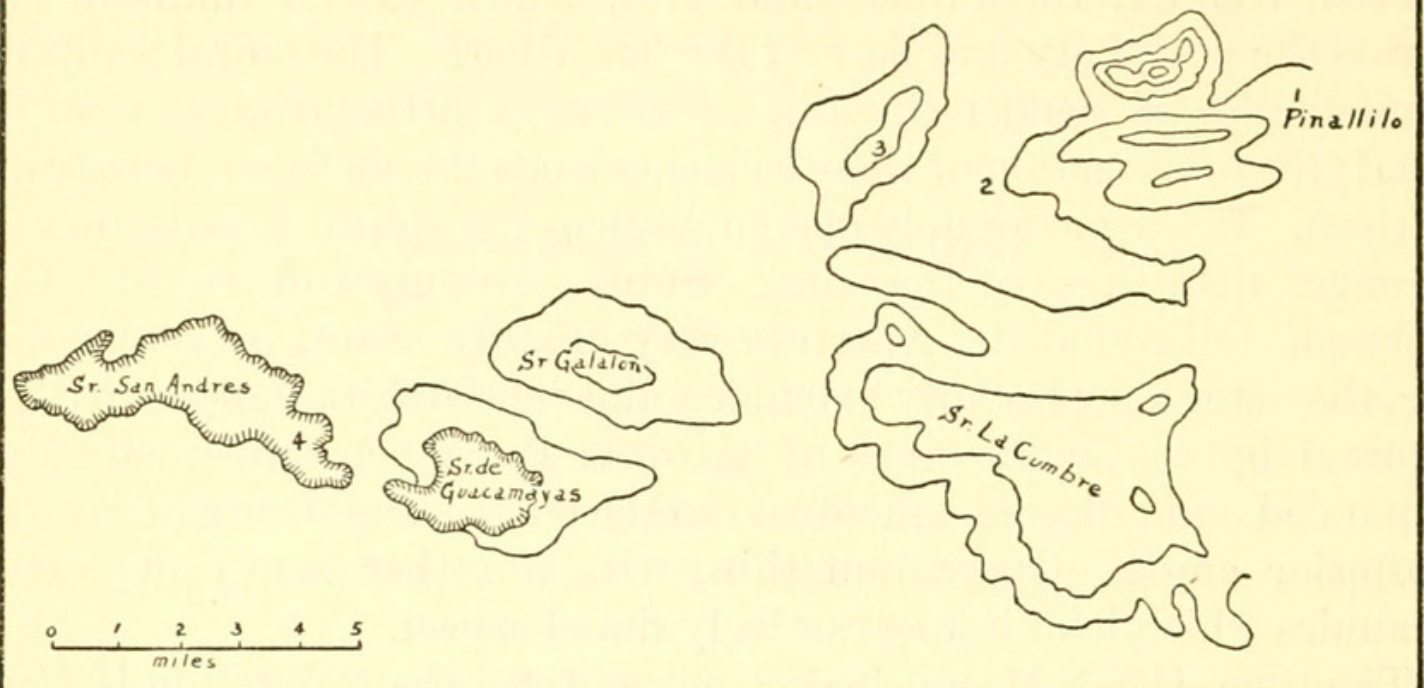

FIGURE 84.-Distribution of the subspecies of Turrithyra (Turrithyra) canaliculata: (1) pinalillensis; (2) saguaensis; (3) canaliculata; (4) andreas.

\section{TURRITHYA (TURRITHYRA) CANALICULATA PINALILLENSIS, new subspecies}

\section{Plate 14, Figure 1}

This race is marked by brown varicial streaks, usually separated by bands of a little wider, of the orange-red base color. It also has inconspicuous brown spiral threads. The outer peristome is tinged with orange-red. It comes from Hato Pinalillo.

The type, U.S.N.M. no. 104500, has 5.3 whorls remaining and measures: Length, $23.5 \mathrm{~mm}$; greater diameter, $12.8 \mathrm{~mm}$; lesser diameter, $9.1 \mathrm{~mm}$.

The dark varicial brown zones readily distinguish this subspecies from the other two.

TURRITHYRA (TURRITHYRA) CANALICULATA ANDREAS, new subspecies

Plate 14, Figure 3

This subspecies, which was collected by Dr. de la Torre at Pico Grande, Sierra San Andrés, has the rather strong axial riblets characteristic of $T .(T$.$) canaliculata pinalillensis and interrupted spiral$ bands of brown narrower and not so strong as those of $T$. (T.) canaliculata saguaensis. 
The type, U.S.N.M. no. 468852, has almost four whorls remaining and measures: Length, $20.2 \mathrm{~mm}$; greater diameter, $12.0 \mathrm{~mm}$; lesser diameter, $9.3 \mathrm{~mm}$.

TURRITHYRA (TURRITHYRA) CANALICULATA SAGUAENSIS, new subspecies

Plate 14, Figure 4

In this race the shell is marked by almost continuous, strong, brown spiral bands on both spire and base. These bands extend upon the peristome, which they mark radially; the rest of the peristome is white.

The type, U.S.N.M. no. 492719, we collected on the Tomas Barrera Expedition at Sagua, Pan de Guajaibon. It has 5 whorls remaining and measures: Length, $23.4 \mathrm{~mm}$; greater diameter, $12.2 \mathrm{~mm}$; lesser diameter, $9.3 \mathrm{~mm}$.

The strong spiral banding and the absence of axial brown streaks characterize this subspecies.

TURRITHYRA (TURRITHYRA) CANALICULATA CANALICULATA (Gundlach) Pfeiffer

Plate 14, Figure 2

1863. Chondropoma canaliculata (Gundlach) Pfeiffer, Malakozool. Blätter, vol. 10, pp. 183-184.

1920. Chondrothyra (Chondrothyra) canaliculatum Henderson and Bartsch, Proc. U. S. Nat. Mus., vol. 58, p. 187.

This race has the shell bright orange-red, unicolor or faintly interruptedly spirally banded. The peristome is of a little paler orange red color. It comes from Hato Caimito.

The specimen figured, U.S.N.M. no. 492718, was collected by Gundlach. It has 4.7 whorls remaining and measures: Length, $23.0 \mathrm{~mm}$; greater diameter, $12.8 \mathrm{~mm}$; lesser diameter, $8.8 \mathrm{~mm}$.

The absence of strong interrupted spiral bands or dark axial streaks easily differentiates this from the other known subspecies.

\section{TURRITHYRA (TURRITHYRA) DECEPTOR (Arango)}

Shell elongate-turreted, ranging in coloration from flesh-color to bright rose-red, unicolor or marked by interrupted spiral threads of brown. The axial ribs are frequently of much lighter color than the rest of the shell. Peristome white, red, or reddish. Nuclear whorls 2, well rounded, smooth. Postnuclear whorls well rounded, marked by sublamellar, retractively slanting axial ribs which extend over the somewhat inflated and well-rounded periphery and base of the last whorl into the moderately open umbilicus. In addition to this sculpture, the whorls on spire and base are marked by numerous fine spiral 
threads. On the umbilical wall the spiral threads become much intensified. Aperture broadly ovate. Peristome double, the outer broadly expanded and reflected, somewhat auriculated at the posterior angle, slightly radially fluted and marked by rather strong concentric incremental lines. Inner peristome only moderately expanded, reflected over and adnate to the outer. Breathing pore on the parietal wall near the posterior angle. Operculum with a rather heavy granular calcareous deposit on the inner two-thirds of the turns.

Races of this species are found from La Jagua south to the Costanera San Vicente.

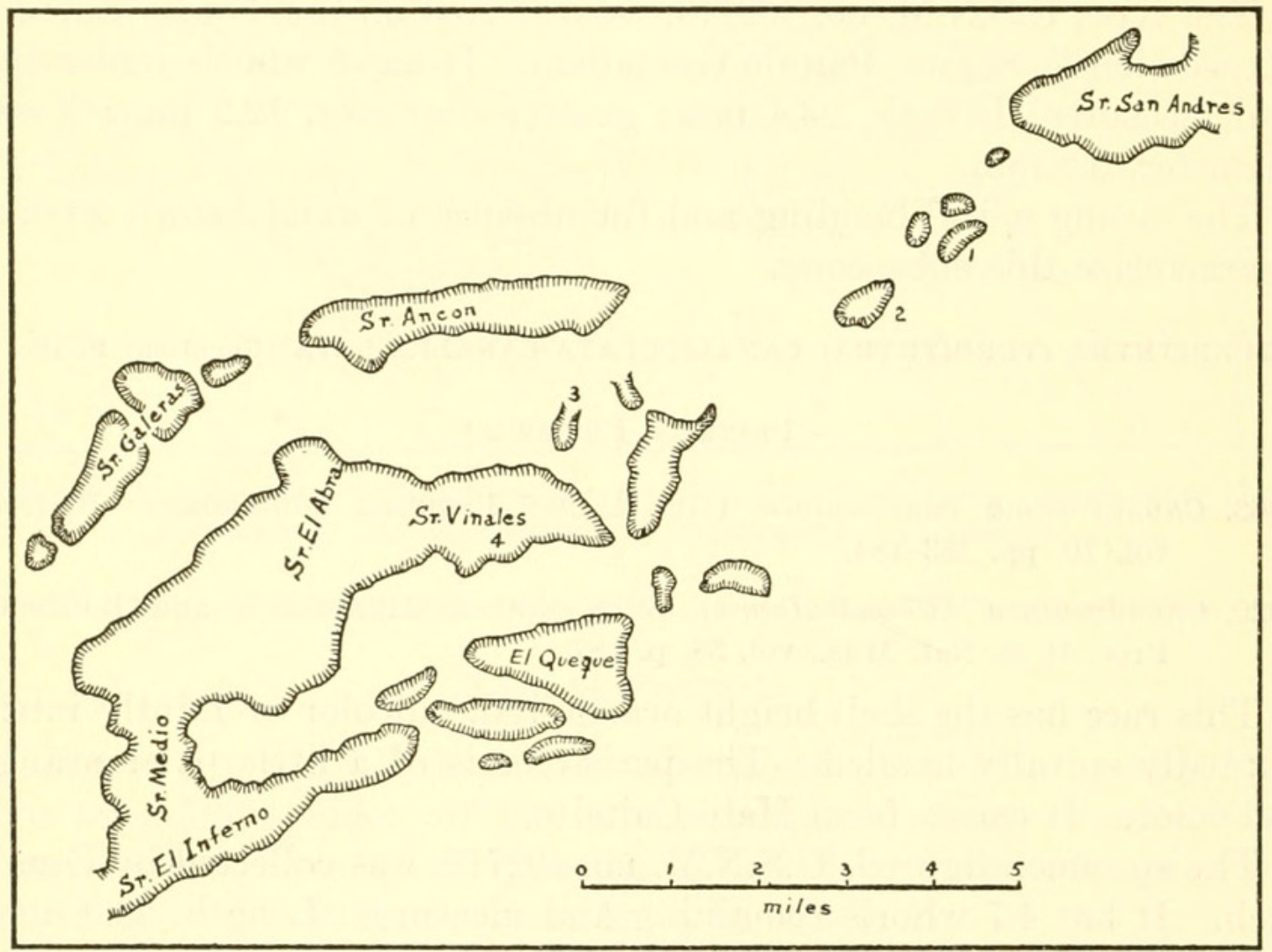

FIGURE 85.-Distribution of the subspecies of Turrithyra (Turrithyra) deceptor: (1) deceptor; (2) persimilis; (3) vicentensis; (4) scalaris.

Distribution of the subspecies of $T$. (T.) deceptor is shown in figure 85 .

KEY TO THE SUBSPECIES OF TURRITHYRA (TURRITHYRA) DECEPTOR

Shell conspicuously spirally banded. scalaris

Shell not conspicuously spirally banded.

Spaces between spiral threads wider than threads.

Axial ribs paler than ground color vicentensis

Axial ribs not paler than ground color. persimilis

Spaces between spiral threads not wider than threads deceptor 
TURRITHYRA (TURRITHYRA) DECEPTOR SCALARIS, new subspecies

Plate 14, Figure 5

This race comes from the Sierra Vinales. Its shell and peristome are pale buff, marked by conspicuous, interrupted spiral bands of brown. The axial ribs and spiral threads here are also considerably stronger than in the other races.

The type, U.S.N.M. no. 492720, has 4.5 whorls remaining and measures: Length, $21.7 \mathrm{~mm}$; greater diameter, $13.2 \mathrm{~mm}$; lesser diameter, $9.7 \mathrm{~mm}$.

\section{TURRITHYRA (TURRITHYRA) DECEPTOR VICENTENSIS, new subspecies}

\section{Plate 14, Figure 7}

This race is rather smaller than the others. The shells range in ground color from buff to bright red, and the peristome is equally variable, but regardless of what shade of coloration the shell may present the axial ribs are always paler than the rest of the shell. This easily distinguishes this subspecies from the rest.

It occupies the Costanera de San Vicente. The type, U.S.N.M. no. 492721, has 5.6 whorls remaining and measures: Length, $19.5 \mathrm{~mm}$; greater diameter, $10.8 \mathrm{~mm}$; lesser diameter, $7.3 \mathrm{~mm}$.

\section{TURRITHYRA (TURRITHYRA) DECEPTOR PERSIMILIS, new subspecies}

\section{Plate 14, Figure 9}

This race comes from Encinar de Alto, frequently called La Mina. Its shell and peristome may be red or soiled white. The red form, while resembling $T$. (T.) deceptor deceptor, as well as the white shells, is easily distinguished from it by having a fewer number and less crowded spiral threads.

The type, U.S.N.M. no. 468730, has 5.0 whorls remaining and measures: Length, $24.2 \mathrm{~mm}$; greater diameter, $13.7 \mathrm{~mm}$; lesser diameter, $9.5 \mathrm{~mm}$.

\section{TURRITHYRA (TURRITHYRA) DECEPTOR DECEPTOR (Arango)}

\section{Plate 14, Figure 8}

1882. Chondropoma deceptor Arango, Proc. Acad. Nat. Sci. Philadelphia, vol. 34, p. 105.

1920. Chondrothyra (Chondrothyra) deceptor Henderson and Bartsoh, Proc.

U. S. Nat. Mus., vol. 58, p. 64 .

This, the northern race of this species, comes from La Jagua, a mogote southwest of the western end of the Sierra San Andrés. It is 
red-shelled with red peristome and has the spiral threads more numerous and closer spaced than the other known subspecies.

The specimen figured, U.S.N.M. no. 468729, is one of Arango's cotypes. It has 5.5 whorls remaining and measures: Length, $23.8 \mathrm{~mm}$; greater diameter, $13.5 \mathrm{~mm}$; lesser diameter, $9.2 \mathrm{~mm}$.

\section{TURRITHYRA (TURRITHYRA) HAMLINI (Arango)}

Shell elongate-turreted of pale buff ground color, marked by interrupted spiral bands of brown, which may also join to form axial varicial streaks; peristome yellowish white. Nuclear whorls a little more than 2, large, strongly inflated and rounded, smooth, except for a few incremental lines on the last part of the last turn. Postnuclear whorls also somewhat inflated and strongly rounded, marked on the early whorls by very slender, almost lamellar, rather closely spaced riblets, which on the last whorls are less elevated and more threadlike. These riblets extend over the inflated and strongly rounded periphery and base of the last whorl into the umbilicus. In addition to this, the whorls bear slender spiral threads, which at their junction with the axial riblets form conspicuous cusps on the early turns and rounded nodules on the later whorls, while the spaces enclosed between them are more or less squarish areolations. In the umbilicus the spiral threads are stronger than on the spire. Aperture subcircular, peristome double, the outer moderately broadly expanded and reflected, somewhat radially fluted and marked with incremental lines, the inner less expanded but also reflected and adnate to the outer. Operculum thin, corneous, covered with a minutely granulose calcareous deposit. Breathing pore on the parietal wall near the posterior angle of the aperture.

This species, as far as known, is restricted to the mogotes ranging about Kilometer 14, between Pinar del Rio and Luis Lazo.

KEY TO THE SUBSPECIES OF TURITHYRA (TURITHYRA) HAMLINI

Cusps formed by junction of axial and spiral sculpture strong on later whorls xilaensis

Cusps formed by junction of axial and spiral sculpture not strong on later whorls.

Dots of spiral bands usually forming axial bands, cerroensis

Dots of spiral bands usually not forming axial bands hamlini

TURRITHYRA (TURRITHYRA) HAMLINI XILAENSIS, new subspecies

Plate 13, Figure 7

This subspecies comes from Mogote de la Vega de Xila Couret near Mogote del Cerra. It differs from the other two in having the cusps formed by the junction of the axial and spiral sculpture much stronger on the later whorls; also in being paler and in having 
the spots of the interrupted spiral bands very small and distantly spaced. The spiral threads in the unbilicus are also much weaker.

The type, U.S.N.M. no. 367902, has 4.5 whorls remaining and measures: Length, $13.7 \mathrm{~mm}$; greater diameter, $7.3 \mathrm{~mm}$; lesser diameter, $6.2 \mathrm{~mm}$.

\section{TURRITHYRA (TURRITHYRA) HAMLINI CERROENSIS, new subspecies}

\section{Plate 13, Figure 6}

In this subspecies, which comes from a mogote removed only a short distance from that occupied by $T$. (T.) hamlini hamlini, the interrupted spiral bands have the dots so broad and arranged in axial series and confluent that the shells appear more axially streaked than spirally banded.

The type, U.S.N.M. no. 468731, has 4.8 whorls remaining and measures: Length, $15.5 \mathrm{~mm}$; greater diameter, $8.3 \mathrm{~mm}$; lesser diameter, $7.0 \mathrm{~mm}$.

TURRITHYRA (TURRITHYRA) HAMLINI HAMLINI (Arango)

Plate 13, Figure 5

1882. Chondropoma hamlini Arango, Proc. Acad. Nat. Sci. Philadelphia, vol. 34, p. 105 .

1920. Chondrothyra (Chondrothyra) hamlini Henderson and Bartsch, Proc. U. S. Nat. Mus., vol. 58, p. 64.

In this race, which comes from the Mogote Cabrera on the north side of the road at Kilometer 14, between Pinar del Rio and Luis Lazo, the interrupted spiral bands, while arranged in axial series, do not fuse to form axial varicial streaks.

The specimen figured, U.S.N.M. no. 492722 , has 4.8 whorls remaining and measures: Length, $15.4 \mathrm{~mm}$; greater diameter, $8.8 \mathrm{~mm}$; lesser diameter, $6.8 \mathrm{~mm}$.

The animal is flesh-color, with a smoky suffusion. The faint pinkish flush shines through the forehead. The foot is medially cleft. Locomotion of the two sides is alternate.

\section{TURRIPOMA, new subgenus}

Those Turrithyras that have no breathing pore, whose peristomes are narrow and uncut.

Type: Turrithyra (Turripoma) bermudezi, new species.

\section{TURRITHYRA (TURRIPOMA) BERMUDEZI, new species}

\section{Plate 13, Figure 2}

Shell elongate-turreted, pale brown, marked by axial zones of dark brown. Nuclear whorls 2, rather large, decidedly inflated, strongly 
rounded, smooth. Postnuclear whorls also inflated and strongly rounded, marked by numerous, retractively slanting, axial threads, which increase in strength with the whorls and form slender nodules where they join the much stronger spiral cords. The latter are of less than half the width of the spaces that separate them. Suture well constricted with white tufts of axial ribs crenulating them. Periphery and base inflated, strongly rounded; scuiptured like the spire. Base openly umbilicated. Last whorl solute for one-tenth of a turn. Aperture broadly ovate; peristome double, the outer more broadly expanded on the inner lip than on the outer; inner peristome slightly expanded and reflected, adnate to the outer. There is no breathing pore. Operculum thin, corneus, with excentric nucleus covered on the inner half by a coarsely granular calcareous deposit.

The type, U.S.N.M. no. 367904, was collected by Dr. Bermudez on palms at the Cueva del Catre, Sierra del Paso Real de Guane. It has 5.2 whorls remaining and measures: Length, $17.0 \mathrm{~mm}$; greater diameter, $7.4 \mathrm{~mm}$; lesser diameter, $6.3 \mathrm{~mm}$.

\section{Genus CHONDROTHYRA Henderson and Bartsch}

1920. Chondrothyra Henderson and Bartsch, Proc. U. S. Nat. Mus., vol. 58, p. 63.

Shell varying from ovate-conic to elongate-conic; marked by axial and spiral threads. Peristome broadly expanded in one plane; that is, not notched or inbent at the umbilicus. The breathing pore perforates the parietal wall a little behind the peristome and a little anterior to the posterior angle of the aperture. Operculum typically chondropomoid.

Type: Cyclostoma egregium (Gundlach) Pfeiffer.

\section{KEY TO THE SUBGENERA OF GENUS CHONDROTHYRA}

Outer peristome of inner lip without fold or pit.

Last whorl decidedly solute and descending.

Hendersonoma

Last whorl not decidedly solute or descending

Chondrothyra Outer peristome of inner lip with fold or pit.

Outer peristome of inner lip with a fold. Plicathyra

Outer peristome of inner lip with a pit Foveothyra

\section{Hendersonoma, new subgenus}

Chondrothyra of gigantic size, with the last whorl decidedly solute for a tenth of a turn and descending. Peristome double, the outer thick, moderately expanded and reflected, much narrower on the parietal wall than on the rest of the aperture, somewhat channeled at the posterior angle. Inner peristome thick, narrowly expanded, reflected, and adnate to the outer.

The large size, solute and descending last whorl, and the fact that the outer peristome of the parietal wall is decidedly free from 

the preceding whorl make this quite distinct from the other Chondrothyras.

Type: Chondrothyra (Hendersonoma) percrassa (Wright) Pfeiffer.

\section{ChONDRothyra (hendersonoma) PERCRASSA (Wright) Pfeiffer}

Plate 15, Figure 6

1864. Licina? percrassa (Wright) Pfeiffer, Malakozool. Blätter, vol. 11, p. 157. 1920. Chondrothyra (Chondrothyra) percrassa Henderson and Bartsch, Proc. U. S. Nat. Mus., vol. 58, p. 63.

Shell gigantic, chestnut-brown, the last whorl a little paler. Nuclear whorls unknown. Postnuclear whorls inflated, well rounded, marked by moderately strong spiral threads, which become enfeebled on the last whorl. These threads are a little narrower than the spaces that separate them. The axial sculpture consists of slender threads on the early postnuclear whorls, which become mere lines of growth on the middle whorls. On the last, faint axial impressed lines at more or less regular intervals are present that in combination with the reduced spiral sculpture lend a somewhat malleated effect to its surface. Suture well constricted. Periphery and base inflated, well rounded, the latter marked like the spire but with the sculpture still more reduced. The last whori is decidedly solute and descending for about one-tenth of a turn. Aperture large, ovate, slightly channeled at the posterior angles. Peristome double, thick, the outer moderately broadly expanded and reflected on all but the parietal wall where it is narrow, somewhat fluted and marked with concentric threads; the inner is also thick, reflected and adnate to the outer. A breathing pore is present on the parietal wall near the posterior angle of the aperture, a little behind the edge of the peristome. Operculum unknown.

The specimen figured, U.S.N.M. no. 492739, was collected by Wright; it has 4.5 whorls remaining and measures: Length, $42.0 \mathrm{~mm}$; greater diameter, $27.0 \mathrm{~mm}$; lesser diameter, $21.4 \mathrm{~mm}$.

This species Pfeiffer states was collected by Wright at "Luis Lazo, Vuelta Abajo." Arango, on the other hand, ${ }^{3}$ says: "En la cima de las montanas de Luis Lazo."

It is to be hoped that this most magnificent form, the largest of all Cuban annularids, may soon be rediscovered and that the place we have assigned it in our present classification may prove correct.

\section{Subgenus Chondrothyra Henderson and Bartsch}

1920. Chondrothyra Henderson and Bartsch, Proc. U. S. Nat. Mus., vol. 58, p. 63.

Shell elongate-ovate, openly umbilicate, varying in color from white through wax yellow, orange, brown, and even purplish, uni-

\footnotetext{
${ }^{3}$ Contribucion a la fauna malacologica Cubana, p. 19, 1878.
} 
color, axially or spirally banded or both. Peristome broadly expanded in one plane, not cut on the inner lip, radiatingly fluted, marked by concentric lines of growth. Breathing pore present on the parietal wall, near the posterior angle of the aperture a little behind its edge. Operculum thin, usually covered more or less with a fine granular calcareous deposit.

Type: Chondropoma egregia (Gundlach) Pfeiffer.

\section{KEY TO THE SPECIES OF SUBGENUS CHONDROTHYRA}

Peristome white or yellowish.

Shell stout.

Greater diameter more than $17 \mathrm{~mm}$ rutila

Greater diameter less than $17 \mathrm{~mm}$ egregia

Shell not stout.

General color chestnut-brown subegregia General color not chestnut-brown.

General color various, but not brown tosta Peristome not white or yellowish.

Peristome blackish brown atristoma

CHONDROTHYRA (CHONDROTHYRA) RUTILA, new species

Shell large, elongate-ovate, with the whorls rather gibbous, with the apex and peristome white; the latter with or without dark radiating rays and axial band behind the peristome. The rest of the shell may be plain brilliant orange or clouded with dark axial zones, as well as spiral markings. Aperture large, broadly oval; peristome double, the outer broadly expanded, radiatingly fluted and marked with concentric laminae, the inner moderately expanded and exserted and adnate to the outer. Operculum thin, corneous, covered with a thick deposit of calcareous granules, which are heaviest on the inner margin and become less dense outwardly, disappearing before reaching the edge.

This species occupies the Mogote El Queque and the little mogote of Martin Miranda.

This differs from the red forms of Chondrothyra (Chondrothyra) tosta in having the sculpture finer.

KEY TO THE SUBSPECIES OF CHONDROTHYRA (CHONDROTHYRA) RUTILA

Shell unicolor rutila

Shell clouded nebulosa

CHONDROTHYRA (CHONDROTHYRA) RUTILA RUTILA, new subspecies

Plate 17, Figure 3

Shell brilliant orange with a more or less strongly developed dark axial zone behind the peristome. The back of the peristome with 
spiral rays, which may or may not show on the face of the peristome. The face of the peristome is pale yellow. Some specimens show a tendency toward interrupted spiral bands on the base.

The type, U.S.N.M. no. 468735, which comes from the Mogote El Queque, is a complete specimen having 7.8 whorls and measuring: Length, $29.7 \mathrm{~mm}$; greater diameter, $17.8 \mathrm{~mm}$; lesser diameter. 12.7 $\mathrm{mm}$.

CHONDROTHYRA (CHONDROTHYRA) RUTILA NEBULOSA, new subspecies

Plate 17, Figure 10

This subspecies, which comes from the small mogote Martin Miranda in the Palmarito, Vinales, near El Queque, has the ground color also orange, but this is decidedly clouded with axial streaks of blackish brown, and there is a tendency to spiral banding on the last whorl. A zone of more or less confluent spots is present on the summit of the whorls. The peristome is pale yellow and faintly radiatingly rayed.

The type, U.S.N.M. no. 468736 , has 4.5 whorls remaining and measures: Length, $28.7 \mathrm{~mm}$; greater diameter, $18.4 \mathrm{~mm}$; lesser diameter, $13.0 \mathrm{~mm}$.

The dark clouding readily distinguishes this subspecies from the other.

ChONDRothyra (CHONDROThYRA) EgRegia (Gundlach) Pfeiffer

Plate 16, Figures 7, 9

1856. Cyclostoma egregium (GUNdLACH) PFEIFfer, Malakozool. Blätter, vol. 3, pp. 38-39.

1856. Chondropoma egregium PFEIfFER, Malakozool. Blätter, vol. 3, p. 134. 1920. Chondrothyra (Chondrothyra) egregium Henderson and Bartsch, Proc. U. S. Nat. Mus., vol. 58, p. 63.

Shell broadly ovate-conic, with the apex and the broadly expanded peristome white to pale yellow, the latter usually marked with radial streaks of brown on the outside. The rest of the shell may be orange or blackish brown; shells of both of these colors are present in the same colony. The shells may or may not be spirally banded. Nuclear whorls almost 2, rather small, well rounded, smooth except for microscopic granulations. The postnuclear whorls are somewhat inflated, well rounded. The first postnuclear whorl shows the beginning of the spiral threads which increase in number and strength as the shell advances in growth. In addition to these spiral threads, the whorls are marked by retractively curved axial threads, which are finer than the spiral and render the latter minutely granulose at their junction. The granuloseness becomes decidedly reduced on the last 
whorl. On this and the whorl preceding, the pits between the axial and spiral sculpture give the shell a somewhat reticulated pattern. Suture moderately constricted, rendered slightly serrulate by the riblets on the summit of the turns, which form here a slender pale zone. Aperture broadly oval; peristome double, the outer decidedly flaringly expanded, slightly channeled at the posterior angle and marked by radial flutings and slender concentric laminae. The inner is but slightly expanded and reflected and adnate to the outer. Operculum thin, with the excentric nucleus covered by a calcareous granular deposit, which is arranged in a somewhat corrugated pattern, in which the corrugations have a retractive slant.

This species comes from Hato Caimito west of Pan de Guajaibon.

The specimens figured are U.S.N.M. no. 468692. The dark perfect individual figured has 7.1 whorls and measures: Length, 27.7 $\mathrm{mm}$; greater diameter, $16.5 \mathrm{~mm}$; lesser diameter, $11.5 \mathrm{~mm}$.

Of this species Gundlach (loc. cit., p. 134) says that the animal is pale rose-red, with the edge of the foot paler and the tentacles uniformly red.

CHONDROTHYRA (CHONDROTHYRA) SUBEGREGIA, new species

Shell elongate-ovate, orange or pale brown, with the peristome pale yellow, unicolor or marked with axial streaks of brown, which sometimes form slight fulgurations. Peristome wax yellow, conspicuously rayed with brown on the outer surface and sometimes on the inner. The early whorls are decollated in all our specimens. The postnuclear whorls are marked by slender spiral threads, which are less than half the width of the spaces that separate them, and retractively slanting axial threads of about the same strength, which on the last whorl, however, become quite evanescent. Suture well constricted, with the merest indication of denticulations at the summit of the whorls. Periphery and base inflated, well rounded, the latter umbilicated and marked like the spire. Aperture broadly oval; peristome double, the outer very broadly expanded, thin, decidedly lamellose and somewhat radially fluted, tending to the formation of a channel at the broadly expanded portion, which is reflected to partly close the umbilicus. Operculum thin with excentric nucleus covered by a heavy deposit of calcareous granules on the inner threefourths, which is laid down in a more or less corrugated pattern.

There are two races of this species known: One from the Mogote de la Jagua and the other from the Sierra San Andrés.

KEY TO THE SUBSPECIES OF CHONDROTHYRA (CHONDROTHYRA) SUBEGREGIA

Surface shining; peristome radiatingly rayed subegregia

Surface dull; peristome not radiatingly rayed paterna 
CHONDROTHYRA (CHONDROTHYRA) SUBEGREGIA SUBEGREGIA, new subspecies

Plate 16, Figure 4

This race, which comes from the Mogote de la Jagua, has the shell smaller and considerably brighter and more shining in color than $C$. (C.) subegregia paterna. It also has the outer expanded peristome conspicuously marked with radiating brown zones.

The type, U.S.N.M. no. 367838, has 3.8 whorls remaining and measures: Length, $24.3 \mathrm{~mm}$; greater diameter, $17.7 \mathrm{~mm}$; lesser diameter, $12.1 \mathrm{~mm}$.

CHONDROTHYRA (CHONDROTHYRA) SUBEGREGIA PATERNA, new subspecies

Plate 16, Figure 5

This race comes from the Sitio de la Sierra San Andrés. It differs from the preceding in having a duller surface and in being almost always without radiating brown zones on the outer peristome.

The type, U.S.N.M. no. 367842, has 4.5 whorls remaining and measures: Length, $28.0 \mathrm{~mm}$; greater diameter, $19.3 \mathrm{~mm}$; lesser diameter, $12.2 \mathrm{~mm}$.

\section{CHONDROTHYRA (CHONDROTHYRA) TOSTA, new species}

Shell ovate-conic, varying in color from white through wax yellow to orange to red, unicolor or banded, always with a dark zone behind the peristome, except $C$. (C.) tosta lactea, which is pure white. Nuclear whorls almost 2 , inflated, strongly rounded, microscopically granulose. Postnuclear whorls marked by rather strong spiral threads and a little less strong and more closely spaced retractively slanting axial threads, which are most conspicuous between the spiral threads and render these minutely nodulose at their junction. The spaces enclosed between the axial and spiral threads are more or less rectangular, having their long axis parallel with the axial sculpture. Suture well constricted. The summit of the whorls being tightly appressed to the preceding turn, leaves an indication of a little narrow band, which is rendered feebly developed by the axial riblets. It should be understood that this is largely a mere indication. Periphery and base of the last whorl inflated and strongly rounded, the latter umbilicate and marked by the same type of sculpture as that which characterizes the spire. Aperture broadly oval, slightly angulated at the junction of the parietal wall with the outer lip, double. The outer broadly flaringly expanded, radially fluted and marked by feeble concentric laminae; the inner also expanded and appressed to the outer. Operculum thin, corneous, covered with a rather heavy deposit of $66879-38-5$ 
calcareous granules, which thins out toward the edge, leaving an uncovered zone on the outer fourth.

The animal of $C$. $(C$.) tosta tosta taken on the north side of the Chorrera near Banos San Vicente, was described by Bartsch in 1928, as follows: Animal short, smoky gray, paler around the base of the tentacles and the anterior portion of the snout. Tentacles coral-red, becoming paler toward the base. Foot longitudinally medially cleft. Locomotion alternate on the two sides.

The animal of $C$. (C.) tosta lactea also was described by Bartsch, as follows: Animal short, ashy gray; tentacles coral-red, brownish at the tip, flesh-colored at the base.

That of $C$. (C.) tosta hesperia, Bartsch described as follows: Body smoky gray, with the base of the tentacles and the edge of the snout flesh-color. The tentacles pass from flesh-color to pale brown to orange, the latter color constituting the major portion. It suspends itself by a mucous thread.

This species ranges from the Sierra de la Chorrera westward through the Organ Mountains to Pan de Azucar and the Sierra del Infierno. We must, however, except the Mogote El Queque and the Ensenada Palmaritas, where $C$. $(C$.) rutila holds forth.

Through this range the species breaks up into a series of subspecies, which the following key will help to differentiate:

Distribution of the subspecies of $C$. (C.) tosta is shown in figure 86 .

KEY TO THE SUBSPECIES OF CHONDROTHYRA (CHONDROTHYRA) TOSTA

Axial dark zone behind peristome present.

Ground color white or pale yellow.

Shell moderately stout tosta

Shell slender hesperia

Ground color not white or pale yellow.

Ground color bright yellow or orange.

Entire shell yellow or orange aurantia Entire shell not yellow or orange.

Last half whorl only deeply colored pertosta Axial dark zone behind peristome absent lactea

CHONDROTHYRA (CHONDROTHYRA) TOSTA TOSTA, new subspecies

Plate 15, Figures 2, 7

In this race, which inhabits the Ensenada de los Banos San Vicente, including the Sierra San Vicente, part of the Chorrera and part of the Sierra Vinales, the ground color is white or faintly yellowish. There is always a dark band even in the white shells immediately behind the peristome, which shines through the substance of the shell and tints the outer lip of the aperture at this place. The shells may also be banded with spiral zones of brown. 
There is a particular tendency toward this on the Chorrera, where we frequently find shells with a brown band at the summit, one at the periphery and one on the middle of the base.

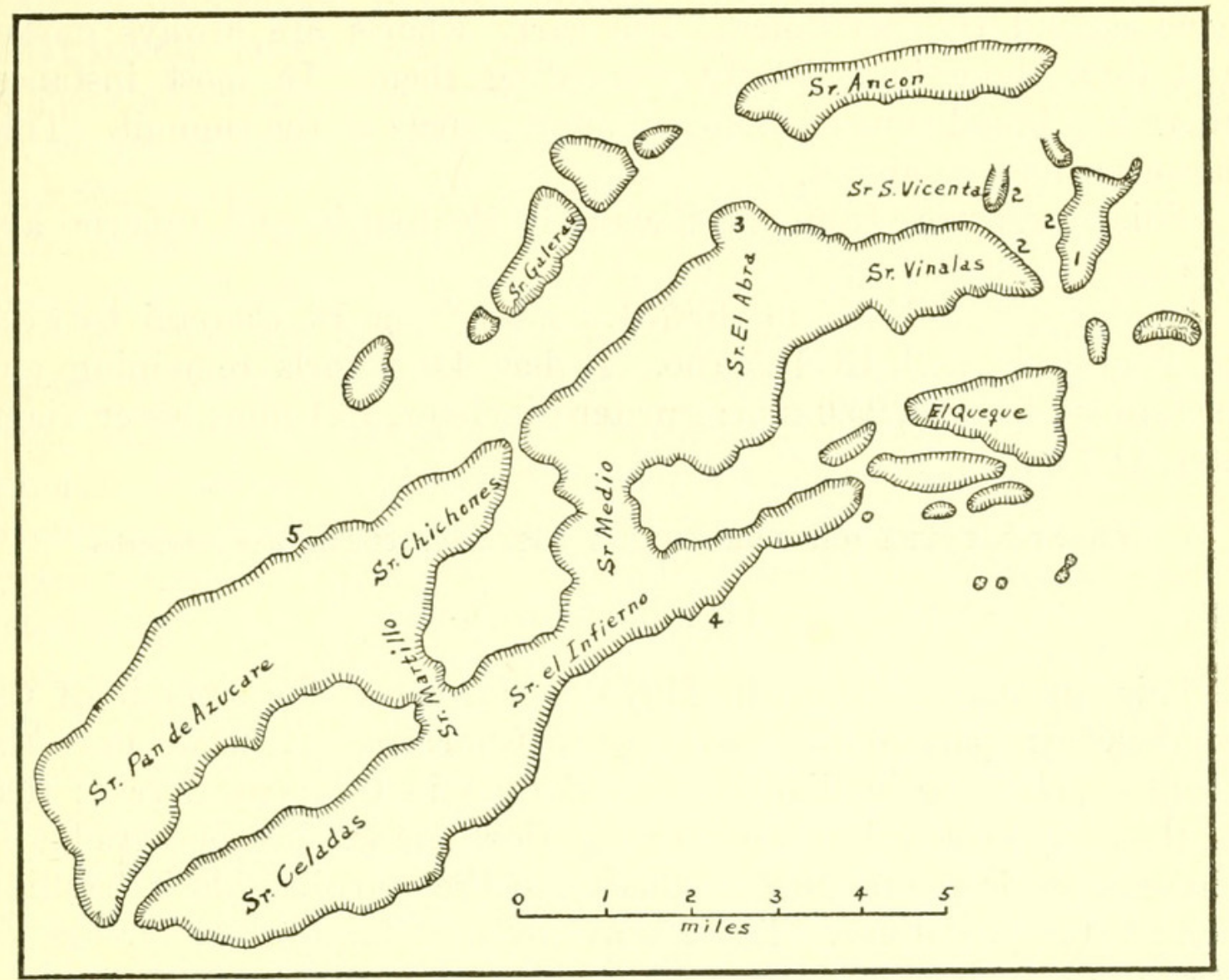

Figure 86.-Distribution of the subspecies of Chrondrothyra (Chondrothyra) tosta: (1) pertosta; (2) tosta; (3) lactea; (4) aurantia; (5) hesperia.

The type, U.S.N.M. no. 492725, has 4.2 whorls remaining and measures: Length, $24.5 \mathrm{~mm}$; greater diameter, $16.4 \mathrm{~mm}$; lesser diameter, $11.8 \mathrm{~mm}$. This was collected at Banos San Vicente.

We are also figuring a banded specimen from the Chorrera at Banos San Vicente.

\section{CHONDROTHYRA (CHONDROTHYRA) TOSTA HESPERIA, new subspecies}

Plate 15, Figure 4

This subspecies, which comes from Pan de Azucar, resembles typical $C$. (C.) tosta but is smaller. The shells are white, with a dark axial zone behind the peristome. The last whorl behind this dark zone has a tendency toward becoming orange. This is usually faint although occasionally a specimen is found which is a little more pronouncedly orange.

The type, U.S.N.M. no. 492727, has 4.0 whorls remaining and measures: Length $24.5 \mathrm{~mm}$; greater diameter, $16.1 \mathrm{~mm}$; lesser diameter, $10.4 \mathrm{~mm}$. 
Ground color yellow or orange, with a conspicuous dark axial zone behind the peristome. The early whorls are always darker red than those immediately succeeding them. In most instances there is a broad zone of almost confluent spots at the summit. This, however, may be absent.

This race comes from the Sierras la Penitencia and Infierno and the mogotes near there.

The type, U.S.N.M. no. 468734, comes from El Cuajani between la Penitencia and El Infierno. It has 4.0 whorls remaining and measures: Length, $25.0 \mathrm{~mm}$; greater diameter, $16.1 \mathrm{~mm}$; lesser diameter, $11.3 \mathrm{~mm}$.

\section{CHONDROTHYRA (CHONDROTHYRA) TOSTA PERTOSTA, new subspecies}

Plate 15, Figure 8

This race comes from the Hoyo de Jaruco at the summit of the southeastern part of the Sierra de la Chorrera. In it we have the shells much more brilliantly colored than in the typical race; that is, the early postnuclear whorls are yellow and the last one gradually changes to deep orange and finally to the purplish-black banding behind the peristome. There may be also faint axial streaks or stronger markings of dark.

The race is also somewhat smaller than the typical one.

The type, U.S.N.M. no. 367837, has 3.8 whorls remaining and measures: Length, $23.0 \mathrm{~mm}$; greater diameter, $15.6 \mathrm{~mm}$; lesser diameter, $11.2 \mathrm{~mm}$.

This subspecies, while it resembles in a way $C$. (C.) tosta aurantia, is easily distinguished from this by its less orange coloration and the concentration of the red color to the last part of the last whorl.

CHONDROTHYRA (CHONDROTHYRA) TOSTA LACTEA, new subspecies

\section{Plate 15, Figure 5}

This subspecies, which comes from the Sierra del Abra, is pure white. There is not the faintest indication of a dark band behind the peristome.

The type, U.S.N.M. no. 492726, has 4.5 whorls remaining and measures: Length, $24.8 \mathrm{~mm}$; greater diameter, $17.6 \mathrm{~mm}$; lesser diameter, $11.4 \mathrm{~mm}$. 
Shell elongate-ovate, with the tip and peristome blackish brown, the rest of the shell varying in the different subspecies from white through pale brown to dark brown. Interrupted spiral bands and axial streaks may or may not be present in some of the subspecies. Nuclear whorls almost 2, small, well rounded, smooth except for microscopic granulations. Postnuclear whorls moderately inflated, well rounded, marked by retractively curved, slender, rather closely spaced, axial threads and spiral threads a little stronger than the axial. The junction of the two form minute nodules, while the spaces enclosed between them are more or less rectangular pits. The axial riblets become reduced on the last whorl. Suture moderately constricted with scarcely any indication of crenulations at the summit of the whorls. Periphery and base inflated and strongly rounded, the latter openly umbilicated and marked by the same type of sculpture that characterizes the spire. Aperture very broadly oval, slightly angulated posteriorly. Peristome double, the outer broadly expanded with a slight tendency to the formation of a channel at the umbilical region, which the broadly expanded peristome partly covers. The outer peristome is radially fluted and marked by concentric laminae. The inner peristome is slightly exserted and slightly reflected. Operculum thin with excentric nucleus covered with a rather heavy finely granulose deposit on the inner three-fourths of the turns.

This species appears peculiar to the Sierra San Andrés and the mogotes to the south of it.

We know at the present time three markedly distinct races, which the following key will help to differentiate:

Distribution of the subspecies of $C$. $(C$.$) atristoma is shown in$ figure 87 .

\section{KEY TO THE SUBSPECIES OF CHONDROTHYRA (CHONDROTHYRA) ATRISTOMA}

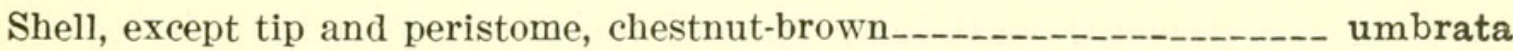

Shell, except tip and peristome, horn-color atristoma

Shell, except tip and peristome, white luctifera

CHONDROTHYRA (CHONDROTHYRA) ATRISTOMA UMBRATA, new subspecies

Plate 16, Figure 3

The early remaining postnuclear whorls dark blackish brown, which gradually changes to chestnut-brown on the later turns. The peritome is dark blackish brown, with a little paler spot on the parietal wall near the posterior angle. The sculpture is that of the species, but the lamellae on the outer peristome are particularly strong here。 This race comes from Pico Grande, Sierra San Andrés. 
The type, U.S.N.M. no. 468695 , has 4 whorls remaining and measures: Length, $23.1 \mathrm{~mm}$; greater diameter, $16.2 \mathrm{~mm}$; lesser diameter, $11.4 \mathrm{~mm}$.

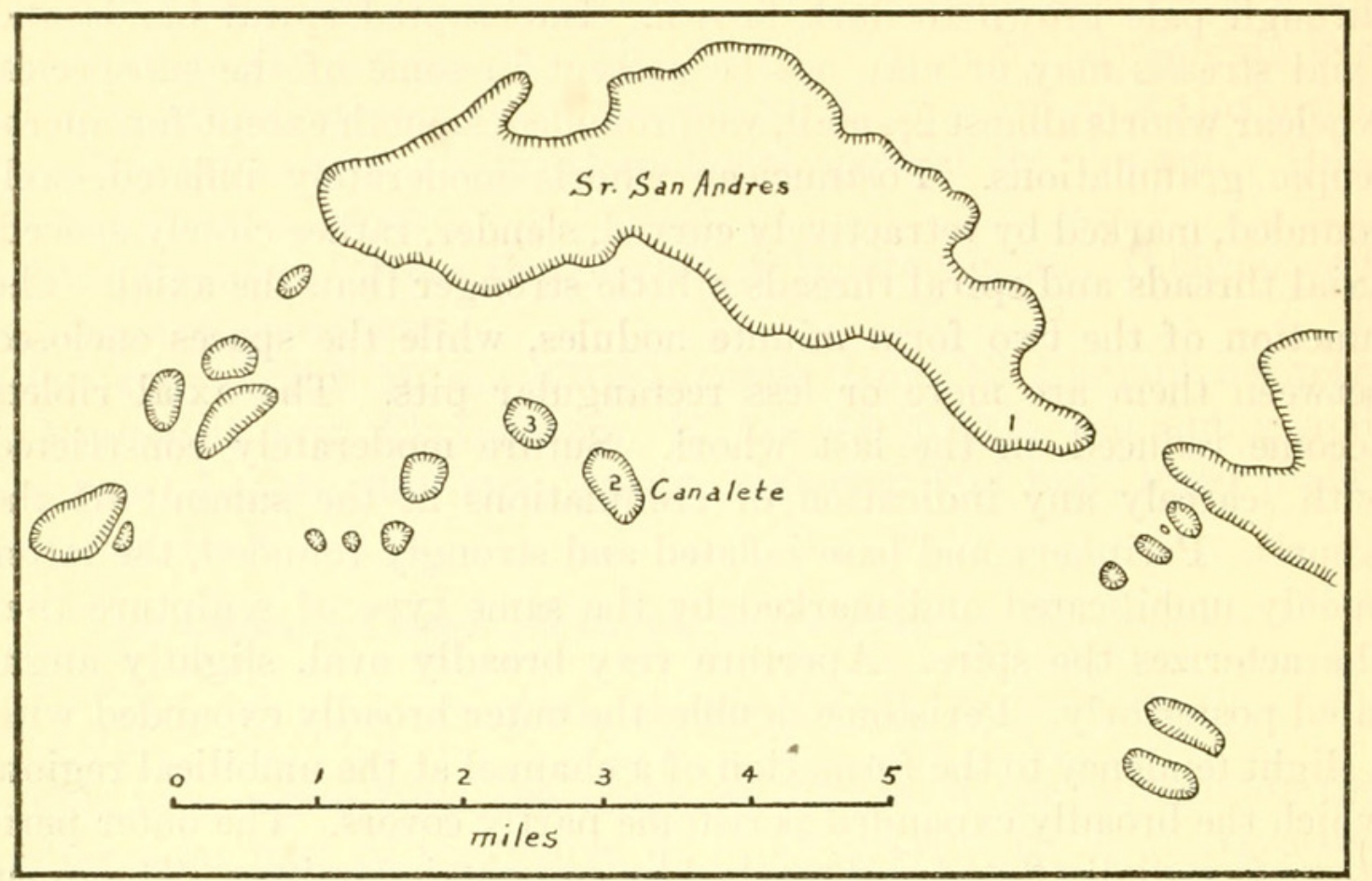

Figure 87.-Distribution of the subspecies of Chondrothyra (Chondrothyra) atristoma: (1) umbrata; (2) luctifera; (3) atristoma.

\section{CHONDROTHYRA (CHONDROTHYRA) ATRISTOMA ATRISTOMA, new subspecies}

Plate 16, Figure 1

Shell broadly ovate, the first fraction of the first whorl white, the rest of the nuclear turns and the three first postnuclear turns dark blackish brown. The remaining postnuclear whorls dark horn-brown, frequently with an interrupted zone of spots near the summit and on the base. The broadly expanded peristome and the outer edge of the inside of the peristome purplish, blackish brown, except for a little spot on the parietal wall near the posterior angle, which is paler. The sculpture is that characteristic of the species.

This race comes from the Abra de Bejarano, Mogote El Canalete.

The type, U.S.N.M. no. 468693 , a perfect specimen, has 7.1 whorls and measures: Length, $27.8 \mathrm{~mm}$; greater diameter, $16.9 \mathrm{~mm}$; lesser diameter, $11.8 \mathrm{~mm}$.

CHONDROTHYRA (CHONDROTHYRA) ATRISTOMA LUCTIFERA, new subspecies

Plate 16, Figure 2

In this subspecies the tip of the shell is dark and so is the peristome, while the rest of the shell is white or pale yellowish, giving it a decidedly mourning effect. The sculpture is that typical of the species. 
This race comes from Mogote del Canalete, south of the Sierra San Andrés.

The type, U.S.N.M. no. 468697 , has 4.5 whorls remaining and measures: Length, $21.6 \mathrm{~mm}$; greater diameter, $14.2 \mathrm{~mm}$; lesser diameter, $9.9 \mathrm{~mm}$.

Plicathyra, new subgenus

Shell similar to Chondrothyra as far as general shape and sculpture are concerned, differing markedly from this, however, by having the outer peristome of the inner lip so bent as to form a fold.

Type: Chondrothyra (Plicathyra) uniplicata, new species.

KEY TO THE SPECIES OF SUBGENUS PLICATHYRA

Shell elongate-ovate.

Shell dark and rather heavy.

Sculpture of last whorl strong

Sculpture of last whorl feeble crassa

Shell pale and rather thin wrighti

CHONDROTHYRA (PLICATHYRA) UNIPLICATA, new species

Plate 16, Figure 6

Shell large, elongate-ovate, rather thin. Nuclear whorls buff. Postnuclear whorls chestnut-brown, except the peristome and the margin of the lip, which are white. Nuclear whorls 2, strongly rounded, smooth except for microscopic granules and the beginning of the spiral threads on the last portion of the last whorl. Postnuclear whorls inflated, strongly rounded, marked by spiral threads and retractively curved axial riblets, which become a little weaker and more closely spaced as the shell increases in size. The junctions of these two elements form small nodules, which are strongest on the middle whorls, while the spaces enclosed between them are squarish on the early whorls and oblong on the last whorl where their long axis coincides with the axial sculpture. The summit of the whorls is appressed and usually shows as a pale line. Periphery and base inflated, well rounded. On the latter the axial and spiral sculpture are both stronger than on the spire. The base is half openly umbilicated. Aperture broadly oval, slightly angulated posteriorly. Peristome double, the outer broadly expanded, somewhat channeled at the posterior angle, more than double the width of that of the outer lip on the posterior half of the inner lip, somewhat radially fluted and marked with strongly developed, wavy, concentric lamellae. The middle of the outer peristome of the inner lip is bent by a partial fold. Inner peristome somewhat exserted and slightly expanded. Operculum thin, corneous, covered with a heavy deposit of calcareous granules, which extend to its edge. 
The type, U.S.N.M. no. 468739, comes from the large mogote at Cayo San Felipe. It is a perfect specimen having 6.8 whorls and measures: Length, $24.8 \mathrm{~mm}$; greater diameter, $14.4 \mathrm{~mm}$; lesser diameter, $10.7 \mathrm{~mm}$.

The animal of this species is ash-gray, with the tentacles coralred, their base being a little paler, gradually passing into flesh-color at their origin. Snout flesh-color at tip. Sole of foot flesh-color with smoky suffusion. Foot medially longitudinally cleft; motion of the two sides alternate.

This species resembles certain forms of Chondrothyretes (Chondrothyretes) reticulata, but the absence of a definite cut in the inner lip of the outer peristome and open umbilicus easily mark its distinction.

\section{CHONDROTHYRA (PLICATHYRA) CRASSA, new species}

\section{Plate 15, Figure 3}

Shell large (early whorls unknown); peristome double, the inner slightly exserted, somewhat expanded; the outer strongly expanded and radiately fluted, the inner lip broader than the outer and adnate to the preceding whorl. The color varies from unicolor yellowish white to dark chestnut-brown, or it may be spirally banded or interruptedly so; in the latter case there is usually an axial arrangement of spots as well as a spiral. Operculum typically chondropomoid.

The type, U.S.N.M. no. 367848, has 3.2 whorls remaining and measures: Length, $31.9 \mathrm{~mm}$; greater diameter, $22.0 \mathrm{~mm}$; lesser diameter, $16.0 \mathrm{~mm}$.

This species comes from the high summits of the Sierra San Carlos between Luiz Lazo and Sumidero. Its large size will readily distinguish it from $C$. (P.) uniplicata, its nearest ally.

\section{CHONDROTHYRA (PLICATHYRA) WRIGHTI, new species}

\section{Plate 16, Figure 8}

Shell rather large, thin, of pale-yellow ground color with numerous interrupted spiral bands of brown, which are also arranged in axial series. These bands are present on both spire and base. The axial arrangement is slightly retractive. The early whorls are decollated in the unique type. Suture feebly denticulated by the axial riblets but well constricted. Periphery strongly rounded. Base moderately long, well rounded. The remaining whorls are slightly inflated, well rounded, and marked by fine, retractively slanting, closely spaced, axial threads, which are about half as wide as the spaces that separate them, and spiral lirations, which are slightly stronger than the axial threads and a little more distantly spaced. The junction of these two elements forms weak nodules, while the spaces enclosed 
between them are more or less squarish or rectangular shallow pits. This sculpture holds good also for the base, except that here the axial threads become a little more approximated and the spiral lirations are a little stronger. Aperture broadly ovate; peristome double, the inner slightly excavated, reflected and adnate to the outer, which is very broadly flaringly expanded, slightly fiuted and marked by slender concentric lamellae. The outer peristome on the inner lip is reflected in its middle to form a fold, not cut. Posterior to this it is reflected over the base so as to almost close the umbilicus, leaving only a narrow chink. On the parietal wall the inner lip extends partly on the base and forms somewhat of an auricle at its junction with the outer lip at the posterior angle.

The type, U.S.N.M. no. 10981, was collected by Wright at La Guira, a place east of the Sierra San Carlos. It has 4.3 whorls remaining and measures: Length, $27.4 \mathrm{~mm}$; greater diameter, $17.8 \mathrm{~mm}$; lesser diameter, $12.6 \mathrm{~mm}$.

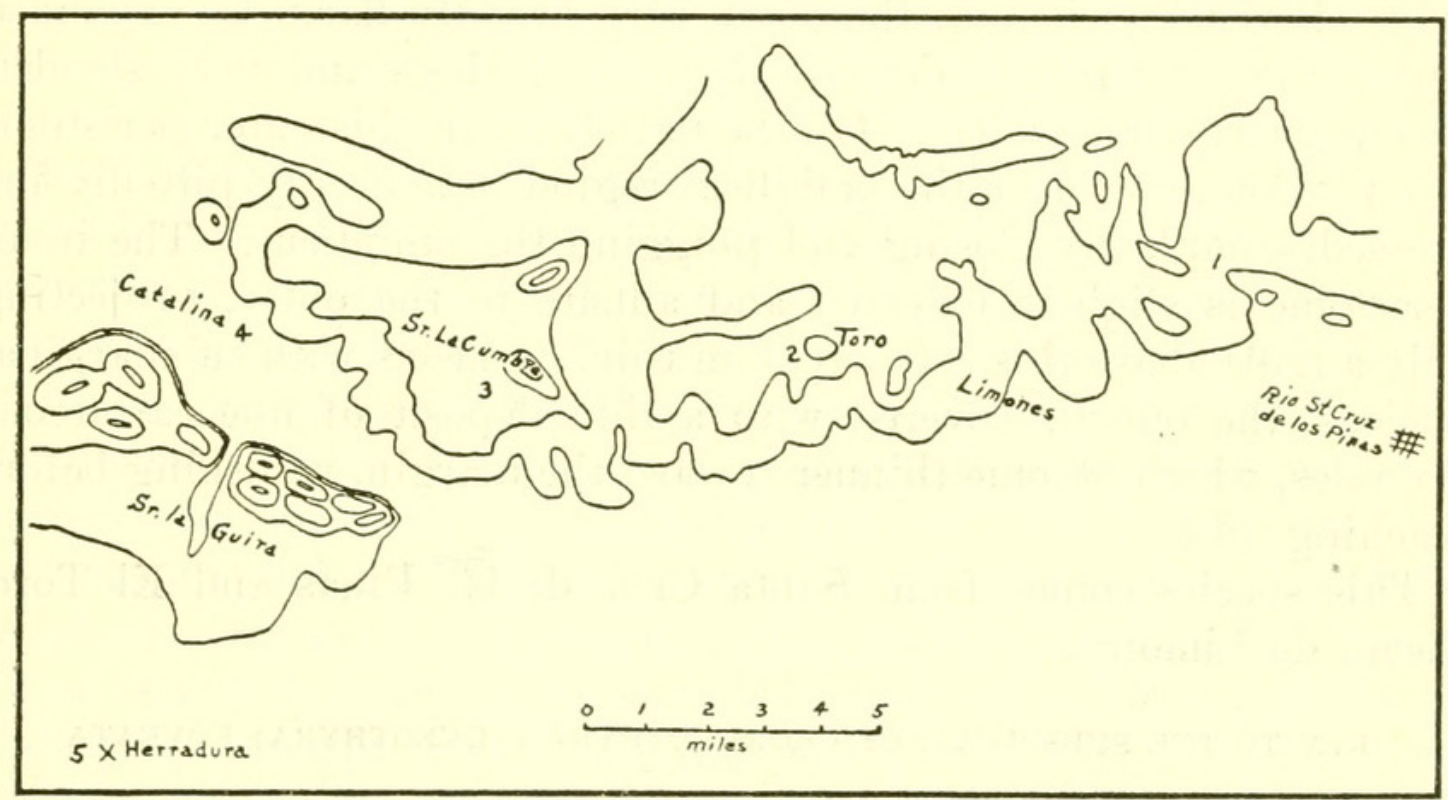

FIGURE 88.-Distribution of the species and subspecies of Foveothyra: (1) C. (F.) foveata foveata; (2) foveata toroensis; (3) cumbrensis cumbrensis; (4) cumbrensis catharina; (5) natensoni.

Foveothyra, new subgenus

Shell like Chonodrothyra, but with the posterior part of the outer peristome of the inner lip punched into the umbilicus, thus forming here a decided pit.

Type: Chondrothyra (Foveothyra) foveata (Gundlach) Pfeiffer.

Distribution of the species and subspecies of the subgenus Foveothyra is shown in figure 88 . 


\section{CHONDROTHYRA (FOVEOTHYRA) FOVEATA (Gundlach) Pfeiffer}

Shell elongate-conic, white or orange, unicolor or faintly spirally banded. Peristome white or pale yellow. Nuclear whorls almost 2 , inflated, strongly rounded, smooth except for fine microscopic granules. Postnuclear whorls also inflated, strongly rounded, and marked by closely spaced, very slender, sublamellar, retractively slanting, axial riblets, which are about one-half the width or less than the spaces that separate them and which render the summits of the whorls minutely crenulated. The spiral sculpture consists of threads of about the same strength as the axial lamellae, but not so elevated, which are of almost the same spacing as the axial riblets. The junction of the spiral threads with the axial riblets renders the latter slightly sinuose and minutely nodulose. Suture well constricted; periphery and base inflated, strongly rounded, the latter marked like the spire with the spiral threads a trifle stronger on the umbilical wall. Aperture broadly oval, slightly angulated posteriorly. Peristome double; the outer very broadly flaringly expanded and marked by poorly developed radial flutings and very slender, weak, concentric lamellae. On the parietal wall this outer peristome is inpinched, and over the umbilical region it is deeply pittedly impressed, completely closing and plugging the umbilicus. The inner peristome is slightly exserted and adnate to the outer, projecting only a trifle above this. Operculum thin, corneous with submarginal nucleus, the outside covered with a thin deposit of fine calcareous granules, which become thinner toward the margin, vanishing before reaching this.

This species comes from Santa Cruz de las Pinas and El Toro, Sierra de Limones.

KEY TO THE SUBSPECIES OF CHONDROTHYRA (FOVEOTHYRA) FOVEATA

Shell slender.

foveata

Shell stout toroensis

CHONDROTHYRA (FOVEOTHYRA) FOVEATA FOVEATA (Gundlach) Pfeiffer

Plate 17, Figure 9

1863. Chondropoma foveatum (GundLACH) PFeiffer, Malakozool. Blätter, vol. 10, pp. 185-186.

1920. Chrondrothyra (Chondrothyretes) foveatum HENDERson and BARTsch, Proc. U. S. Nat. Mus., vol. 58, p. 64 .

This subspecies is pale wax yellow with white peristome, marked by obscure interrupted spiral lines of brown. The peristome is much slenderer than in the next species and has the whorls less inflated and the sculpture considerably reduced on the last whorl and not nearly so prominent on all the whorls. 
It comes from Rio Santa Cruz de los Pinas.

The specimen figured, U.S.N.M. no. 492728, lacks the nuclear whorls. It has 5.3 whorls remaining and measures: Length, 24.3 $\mathrm{mm}$; greater diameter, $15.9 \mathrm{~mm}$; lesser diameter, $9.6 \mathrm{~mm}$.

CHONDROTHYRA (FOVEOTHYRA) FOVEATA TOROENSIS, new subspecies

\section{Plate 17, Figure 11}

In this race, which comes from El Toro of the Sierra de Limones, the shell is pale chestnut-brown, with the peristome pale yellow. Faint interrupted spiral lines of brown are present also. The whorls in this race are much more inflated than in the typical race, and the sculpture is in every way much stronger and more pronounced.

The type, U.S.N.M. no. 492729 , has 4.8 whorls remaining and measures: Length, $23.5 \mathrm{~mm}$; greater diameter, $15.8 \mathrm{~mm}$; lesser diameter, $10.5 \mathrm{~mm}$.

\section{CHONDROTHYRA (FOVEOTHYRA) NATENSONI, new species}

\section{Plate 17, Figure 8}

Shell small, elongate-ovate, pale yellow, with faint interrupted spiral bands. Nuclear whorls 2, well rounded, smooth, marked with microscopic granulations. Postnuclear whorls inflated, strongly rounded, marked by retractively slanting, sublamellar axial riblets, which are somewhat thickened at the summit and render this slightly crenulated. These threads are rather closely spaced, being about half as wide as the spaces that separate them on the last turn. In addition to this, the whorls are marked by slender spiral threads, which are less than half the width of the spaces that separate them. These render the axial riblets slightly sinuose and feebly nodulose. This sculpture also obtains on the inflated and well-rounded base. Operculum oval; peristome double, the outer flaringly expanded, deeply pitted at the umbilical region and forming a channel on the parietal wall between the inner lip and the parietal wall. The inner peristome is exserted and slightly reflected. Operculum paucispiral, thin, covered with a thick granular calcareous deposit.

The type, U.S.N.M. no. 468738, was collected by Natenson at the Entronque de Herradura. It has 4 whorls remaining and measures: Length, $14.2 \mathrm{~mm}$; greater diameter, $9.3 \mathrm{~mm}$; lesser diameter, $6.8 \mathrm{~mm}$.

The small size will easily distinguish this from the other species.

CHONDROTHYRA (FOVEOTHYRA) CUMBRENSIS, new species

Shell ovate, wax yellow with interrupted spiral bands of brown. The nuclear whorls are decollated in all our specimens. Postnuclear whorls inflated, strongly rounded, marked with sublamellar, retrac- 
tively slanting, axial riblets, which develop into slender cusps at the appressed summit and fine spiral threads, which render the axial riblets slightly sinuose and somewhat thickened at their junction. This sculpture extends over the inflated, strongly rounded, periphery and base. Aperture ovate, slightly angulated posteriorly. Peristome double, the outer very broadly flaringly expanded, somewhat radially fluted and marked with concentric lines of growth; the inner decidedly exserted, scarcely at all reflected. The space between the parietal wall and the inner peristome is rather broad and is covered by the outer peristome which is here inpinched to form a decided channel, terminating in the deep pit, which plugs the umbilicus. Operculum paucispiral, covered with a rather heavy calcareous granular deposit, which thins out toward the edge and disappears before reaching this.

This species differs from $C$. $(F$.) foveata in being shorter and more ovate and in having the space between the inner lip and the parietal wall much more deeply impressed.

It comes from La Cumbre Mountain and from Los Cayitos la Catalina north of San Diego Banos, the two localities representing distinct subspecies, which the following key will help to differentiate:

KEY TO THE SUBSPECIES OF CHONDROTHYRA (FOVEOTHYRA) CUMBRENSIS

Interrupted spiral bands very strong cumbrensis Interrupted spiral bands feeble catharina

CHONDROTHYRA (FOVEOTHYRA) CUMBRENSIS CUMBRENSIS, new subspecies Plate 17, Figure 6

Shell varying considerably in size with the whorls inflated, strongly rounded, and marked by rather pronounced interrupted spiral zones on spire and base. These zones are also conspicuous on the outer peristome of the last whorl, which here is unusually broad.

The type, U.S.N.M. no. 492730, was collected by John B. Henderson in the Sierra la Cumbre. It has 4.3 whorls remaining and measures: Length, $18.2 \mathrm{~mm}$; greater diameter, $14.2 \mathrm{~mm}$; lesser diameter, $9.3 \mathrm{~mm}$.

CHONDROTHYRA (FOVEOTHYRA) CUMBRENSIS CATHARINA, new subspecies

Plate 17, Figure 7

This race averages smaller with the interrupted spiral bands narrower and fainter and scarcely indicated on the outer peristome. The umbilical pit here is unusually deep. 
The type, U.S.N.M. no. 468737, comes from Los Cayitos la Catalina north of San Diego Banos. It has 5 whorls remaining and measures: Length, $16.2 \mathrm{~mm}$; greater diameter, $11.7 \mathrm{~mm}$; lesser diameter, $7.2 \mathrm{~mm}$.

\section{Genus CHONDROTHYRETES Henderson and Bartsch}

1920. Chondrothyra (Chondrothyretes) Henderson and Bartsch, Proc. U. S. Nat. Mus., vol. 58, p. 64 .

Shell varying from ovate-conic to ovate-turreted, marked with axial and spiral threads. Aperture varying from ovate to subcircular; peristome double, the outer usually broadly expanded and reflected, always deeply cut on the inner lip, with the part posterior to the cut reflected over the umbilicus, which is completely or almost completely closed; inner peristome short, reflected and adnate to the outer. A breathing pore is present, which may open directly to the exterior or through a connecting channel communicating with the exterior by way of the hollow truncated axis. Operculum paucispiral with excentric nucleus covered to a varying degree with a deposit of fine calcareous granules.

Type: Chondrothyretes shuttleworthi (Pfeiffer).

The main distribution of the members of this genus falls into Pinar del Rio Province; a few species, however, extend eastward into Havana Province.

\section{KEY TO THE SPECIES OF GENUS CHONDROTHYRETES}

Shells of medium size, thin.

Outer peristome of inner lip, above cut, pressed into umbilicus_---- impressa

Outer peristome of inner lip, above cut, not pressed into umbilicus

delectabilis

Shell large and heavy.

Spiral sculpture decidedly stronger than axial.

Hydrophanous axial streaks present. affinis

Hydrophanous axial streaks absent.

Axial sculpture of last whorl quite strong_________-_ gundlachi

Axial sculpture of last whorl feeble parilis

Spiral sculpture not decidedly stronger than axial.

Junctions of axial riblets and spiral threads forming prom-

inent nodules.

Outer lip conspicuously rayed tenebrata.

Outer lip not conspicuously rayed. reticulats

Junctions of axial riblets and spiral threads not forming prominent nodules.

Axial and spiral sculpture moderately strong.

Outer peristome thin, broadly expanded.

Shell ponderous barbour:

Shell not ponderous shuttleworth!

Outer peristome thickened, not broadly expanded_- incrassata Axial and spiral sculpture obsolete cerina 
Pfeiffer, in describing Cyclostoma shuttleworthi, does not mention a type locality for his species, but in his reference to it in the Monographia pneumonopomorum in 1852 , page 295 , he states that his specimen was in the Cumings Museum. His figure in MartiniChemnitz Conchylien Cabinet, plate 36, figure 7, and also the description on pages $265-266$, leave no doubt in our minds that this specimen is one of the San Diego Banos complex. Poey, in describing Cyclostoma verecundum in his Memorias sobre la historia natural de la Isla de Cuba, volume 1, pages 102-103, says that his specimens were received from D. Jose Maria Velasquez who collected them at San Diego de los Banos.

Henderson and Simpson's exhaustive collecting in the region of San Diego Banos in 1913, Bartsch's in 1928, as well as the more recent collecting by Bermudez, Aguayo, and Natenson, have resulted in the accumulation of a mass of material with definite localities, which enable us to fairly adequately understand the distribution of this species and its breaking up into a definite series of zoogeographic races, which we are designating as subspecies.

These here, as elsewhere, have their definite physical limitations and are undoubtedly segregation products, the results of erosion and the isolation caused thereby.

The species is confined to the Pinar del Rio Province and ranges from San Diego Banos northward to the Sierra la Cumbre and La Catalina, east of the Rio San Diego. It extends westward through the mogotes facing the Sierra la Guira, as well as this sierra, then westward through the Sierra Guacamayas, and from there southward to Mogote Mamey.

Shell ovate, varying from medium to rather large in size, varying in ground color from flesh-color, through straw-color, through yellow to orange and brown in different individuals, always with some spiral markings. These may constitute definite bands or interrupted lines, which if seeming absent are at least expressed as rays upon the expanded peristome. The interrupted spiral markings are at times so arranged as to constitute axial zones. Nuclear whorls about 2, inflated, strongly rounded, smooth except the last portion of the last whorl, which shows the feeble beginning of the postnuclear sculpture. A small dark patch marks the suture of the first nuclear turn. Postnuclear whorls inflated, gibbose, marked by numerous, about equal, and equally spaced axial and spiral threads, which in one group of subspecies retain their strength on the last turn, while in another group we find the axial threads decidedly reduced. Suture moderately 
constricted with but the merest suggestion of obsolete denticulations at the summit of the whorls. Periphery inflated, strongly rounded. Base rather short, inflated, and rounded and marked like the spire. Aperture broadly ovate; peristome double, the inner slightly exserted and reflected; the outer broadly flaringly expanded, fluted, and marked by concentric threads, cut in the middle of the inner lip almost to the inner peristome, the posterior half being reflected over the umbilicus and parietal wall as a strong callus; parietal wall also covered with an extensive callus. Operculum paucispiral with excentric nucleus, having the last whorl covered with a heavy granular calcareous deposit.

Of the animal we have the following notes:

Of $C$. shuttleworthi shuttleworthi the sides of body, sole of foot, and tip of snout are pale smoky gray, the upper portion being darker. Base of tentacles surrounded by a white ring, the rest crimson; the lateral edges of the expanded tip are smoky. Sole of foot medially cleft; locomotion of the two sides alternate.

The animal of $C$. shuttleworthi portica is smoky gray with a buff tinge, the edge and sole of the foot pale buff, which is also the color of the tip of the snout. Tentacles with a flesh-colored ring about the base, the rest crimson except for the slightly expanded distal portion, which is smoky on the sides. The internal pink anatomy shines slightly through the integument behind the tentacles. Foot medially cleft; locomotion of the two sides alternate.

The animal of $C$. shuttleworthi atriola is smoke gray, being a little darker on top than on the sides. There is a white ring about the tentacles at their base, the rest being bright red, except for the slightly expanded distal portion, which has a yellow tinge, the tip of the snout being slightly paler. The sole of the foot is longitudinally cleft, pale smoke-gray.

The animal of $C$. shuttleworthi clivicola is pale smoke-gray. Tentacles almost sooty with a subterminal paler band. Snout a little paler than the general coloration of the body; edge of the body at the junction of the foot flesh-color. Sole of the foot flesh-color, with a faint smoky suffusion. The internal anatomy shines through the body wall behind the tentacles with a rosy flush. The short foot is medially deeply cleft, progression being alternate by the two sides.

Distribution of the subspecies of $C$. shuttleworthi is shown in figure 89 . 


\section{KEY TO THE SUBSPECIES OF CHONDROTHYRETES SHUTTLEWORTHI}

Axial sculpture of last whorl less strong than spiral.

Greater diameter more than $16 \mathrm{~mm}$.

Inner peristome greatly expanded and thickened_ cumbrensis

Inner peristome not greatly expanded and thickened.

Decollated shell with 3.5 whorls shuttleworthi

Decollated shell with 4.5 whorls. portica

Greater diameter less than $15 \mathrm{~mm}$.

Back of outer peristome broadly rayed atriola

Back of outer peristome not broadly rayed____________-_ mameyensis Axial sculpture of last whorl as strong as spiral.

Whorls gibbose.

Greater diameter more than $15 \mathrm{~mm}$ clivicola

Greater diameter less than $15 \mathrm{~mm}$ catalinensis perplexa

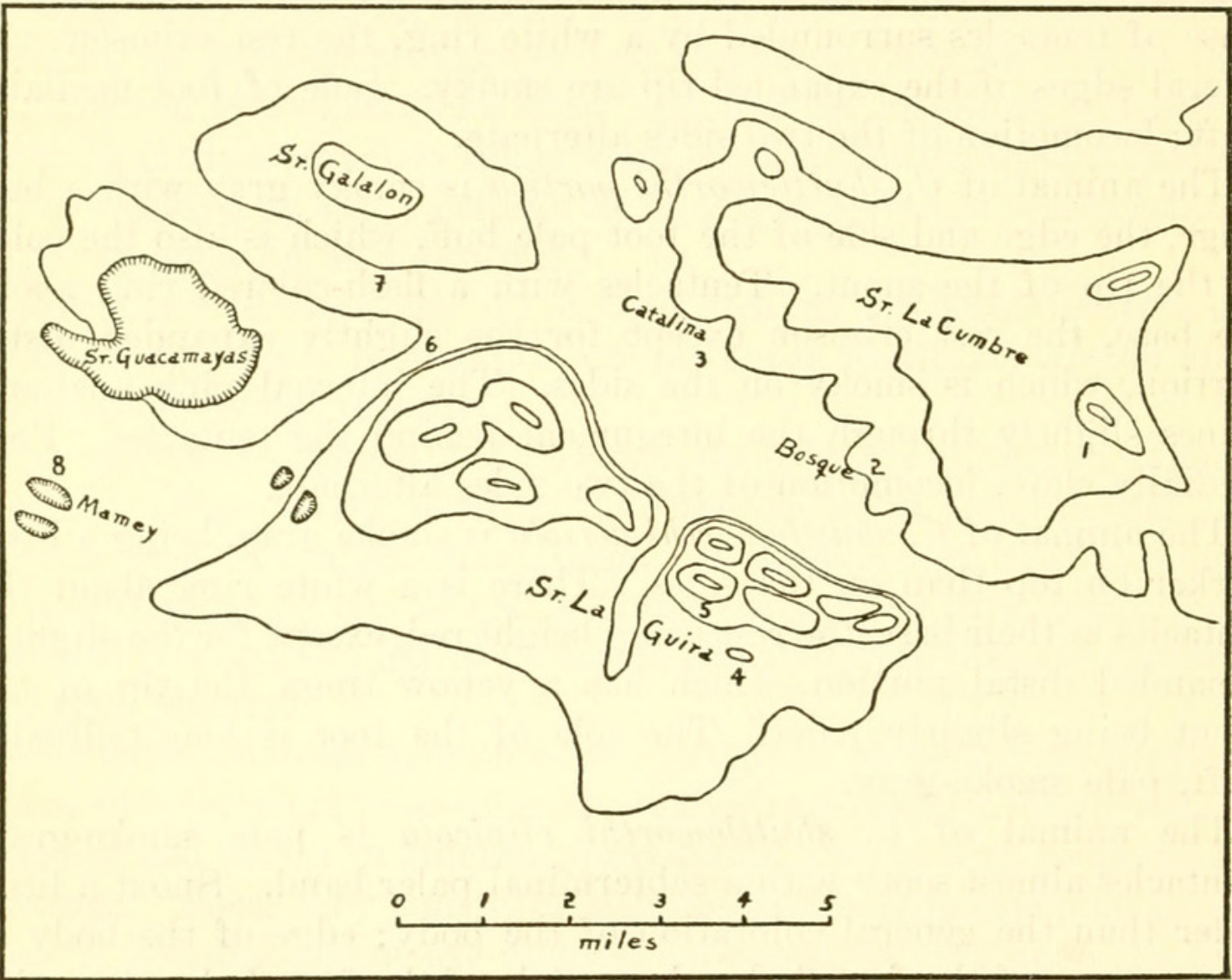

Figure 89.-Distribution of the subspecies of Chondrothyretes shuttleworthi: (1) cumbrensis; (2) clivicola; (3) catalinensis; (4) shuttleworthi; (5) perplexa; (6) portica; (7) atriola; (8) mameyensis.

\section{CHONDROTHYRETES SHUTTLEWORTHI CUMBRENSIS, new subspecies}

Plate 19, Figure 5

Shell similar in size and shape to $C$. shuttleworthi shuttleworthi, but with the inner peristome broadly expanded, much thickened, and reflected over half of the outer.

The type series of specimens were collected by John B. Henderson in the Sierra la Cumbre north of San Diego Banos, east of the Rio 
San Diego. The type, U.S.N.M. no. 493294, has 3.5 whorls remaining and measures: Length, $25.6 \mathrm{~mm}$; greater diameter, $17.4 \mathrm{~mm}$; lesser diameter, $13.7 \mathrm{~mm}$.

\section{CHONDROTHYRETES SHUTTLEWORTHI SHUTTLEWORTHI (Pfeiffer)}

\section{Plate 19, Figure 9}

1851. Cyclostoma shuttleworthi PFeIfFer, Proc. Zool. Soc. London, 1851, p. 246. 1851. Cyclostoma verecundum PoEY, Memorias sobre la historia natural de la Isla de Cuba, pp. 102-103, 106, 144, pl. 7, figs. 5-7.

The typical subspecies ranges from San Diego de los Banos west through the mogotes leading to the Sierra la Guira, this sierra, and the Abra de Caiguanabo. It is a large shell, of stumpy appearance, with inflated swollen whorls having the axial riblets reduced on the last whorl; the shell is thereby given a somewhat smooth appearance. The shell is almost always decollated, leaving about 3.5 whorls remaining. It is very variable in coloration, presenting all the variations mentioned under the species.

The specimen figured, U.S.N.M. no. 492867, was collected by John B. Henderson at the mogote next to the Sierra la Guira. It is a perfect specimen, having 7.0 whorls and measuring: Length, 26.1 $\mathrm{mm}$; greater diameter, $15.9 \mathrm{~mm}$; lesser diameter, $12.6 \mathrm{~mm}$.

\section{CHONDROTHYRETES SHUTTLEWORTHI PORTICA, new subspecies}

Plate 19, Figure 7

This subspecies ranges from the mogotes Abra de Caiguanabo to Los Portales.

This race is smaller than the typical one. It is more strongly sculptured and less inflated, and the decollated shell usually has 4.5 whorls. It always averages darker in coloration and is usually more heavily banded.

The type, U.S.N.M. no. 468881, is a complete specimen and is rather large for the subspecies. We have selected it on account of its completeness. It comes from Los Portales. It has 7.2 whorls remaining and measures: Length, $28.8 \mathrm{~mm}$; greater diameter, $16.8 \mathrm{~mm}$; lesser diameter, $12.2 \mathrm{~mm}$.

CHONDROTHYRETES SHUTTLEWORTHI ATRIOLA, new subspecies

Plate 19, Figure 8

This is a small race that comes from Los Portales, about Espejo Cueva Oscura, and the Mogote Galalón. It frequently is bright red in color, and the back of the expanded peristome is conspicuously broadly rayed.

$66879-38-6$ 
The type, U.S.N.M. no. 468886, has 4.2 whorls remaining and measures: Length, $22.2 \mathrm{~mm}$; greater diameter, $15.7 \mathrm{~mm}$; lesser diameter, $10.9 \mathrm{~mm}$.

CHONDROTHYRETES SHUTTLEWORTHI MAMEYENSIS, new subspecies

\section{Plate 18, Figure 8}

This race comes from the Mogote Mamey, the northern one of the two hills about 2 miles south of the gap that separates the Sierra San Andrés from the Sierra Guacamayas. It is a small, pale, thinshelled race, narrowly rayed on the back of the outer peristome.

The type, U.S.N.M. no. 468889 , has 5.0 whorls remaining and measures: Length, $21.0 \mathrm{~mm}$; greater diameter, $14.0 \mathrm{~mm}$; lesser diameter, $10.2 \mathrm{~mm}$.

\section{CHONDROTHYRETES SHUTTLEWORTHI CLIVICOLA, new subspecies}

Plate 19, Figure 4

This race occupies the series of paredones on the east side of the Rio Santa Cruz and ranges from Mogote Indios to Mogote Colorado to Mogote Bosque. It has the axial threads equaling the spiral on the last whorl and so renders this finely latticed. It is a mediumsized race, varying greatly in coloration, but is always more or less interruptedly spirally banded.

The type, U.S.N.M. no. 468891, comes from the Mogote Bosque, has 4.0 whorls remaining, and measures: Length, $22.5 \mathrm{~mm}$; greater diameter, $15.0 \mathrm{~mm}$; lesser diameter, $11.0 \mathrm{~mm}$.

\section{CHONDROTHYRETES SHUTTLEWORTHI CATALINENSIS, new subspecies}

\section{Plate 18, Figure 9}

This subspecies, which also has the last whorl strongly latticed, was collected about La Catalina, which is several miles to the north of Mogote Bosque. It is a small, pale, thin-shelled race, with the outer peristome conspicuously rayed.

The type, U.S.N.M. no. 468893, a complete specimen, has 6.2 whorls and measures: Length, $19.5 \mathrm{~mm}$; greater diameter, $12.6 \mathrm{~mm}$; lesser diameter, $9.2 \mathrm{~mm}$.

\section{CHONDROTHYRETES SHUTTLEWORTHI PERPLEXA, new subspecies}

\section{Plate 18, Figure 7}

At the Mogote de la Finca, a little southeast of the Sierra la Guira, Henderson and Natenson collected a thin-shelled small race, which has the last whorl latticed, in this way resembling $C$. shuttleworthi clivicola and C.s. catatinensis. This is on the west side of the Rio 
San Diego and apparently in the range of typical $C$. shuttleworthi shuttleworthi. We say apparently because it is possible that typical shuttleworthi may not be occupying exactly the same habitat, but at all events we have here a condition where two subspecies appear to occupy the same range, which is, to say the least, unusual. There is a possibility that when anatomically examined the strongly latticed group may prove a distinct species from $C$. shuttleworthi, in which the last whorl is not latticed. We are not deciding this question here, but merely reporting conditions.

This race is horn-colored with interrupted irregular spots, dots, and blotches of pale brown. The last whorl is a little less swollen than in the two preceding races.

The type, U.S.N.M. no 468895, which comes from the Mogote de la Finca, is a complete specimen, having 7.0 whorls. It measures: Length, $21.0 \mathrm{~mm}$; greater diameter, $13.0 \mathrm{~mm}$; lesser diameter, $9.2 \mathrm{~mm}$.

CHONDROTHYRETES IMPRESSA, new species

Shell varying from small to medium sized, thin, pale yellow or flesh-color, marked with interrupted spiral bands of brown on both spire and base. Peristome faintly yellow, unicolor or radiately rayed. Nuclear whorls about 2, inflated, well rounded, smooth except for microscopic granulations and the beginning of the spiral threads on the last part of the last whorl. Postnuclear whorls also inflated and strongly rounded, feebly tufted at the summit, covered by numerous retractively slanting axial riblets and equally strong spiral threads, which form small nodules at their junction. Periphery and base inflated and strongly rounded with both the axial and spiral sculpture a little more strongly developed in the umbilical region than on the spire. The base is rather widely umbilicate, but the umbilicus is concealed to a varying degree by the strongly reflected outer peristome of the inner lip. Aperture broadly ovate. Peristome double, the outer broadly expanded and reflected, usually of double the width on the inner lip, posterior to the fold, as on the rest of the peristome. The outer peristome is usually radially futed and concentrically laminated. The inner peristome is somewhat exserted and slightly reflected. Operculum thin, corneous, covered by a rather heavy, somewhat wavy, granular, calcareous deposit.

The animal of $C$. impressa hyans is smoke-gray, a little paler on the sides near the foot, as well as the sole of the foot and tip of the snout. Tentacles dull orange, with the expanded tip a little sooty on the side. There is a pinkish coloration shining through the body of the animal behind the tentacles.

The animal of $C$. impressa ornata is quite uniformly dark smoky gray. Tentacles orange with sooty tips. Sole medially cleft; mo- 
tion of the two sides alternate. It suspends itself by a mucous thread when at rest.

The distribution of this species is rather extensive. It appears to range through a considerable area of the mogotes south of the Organ

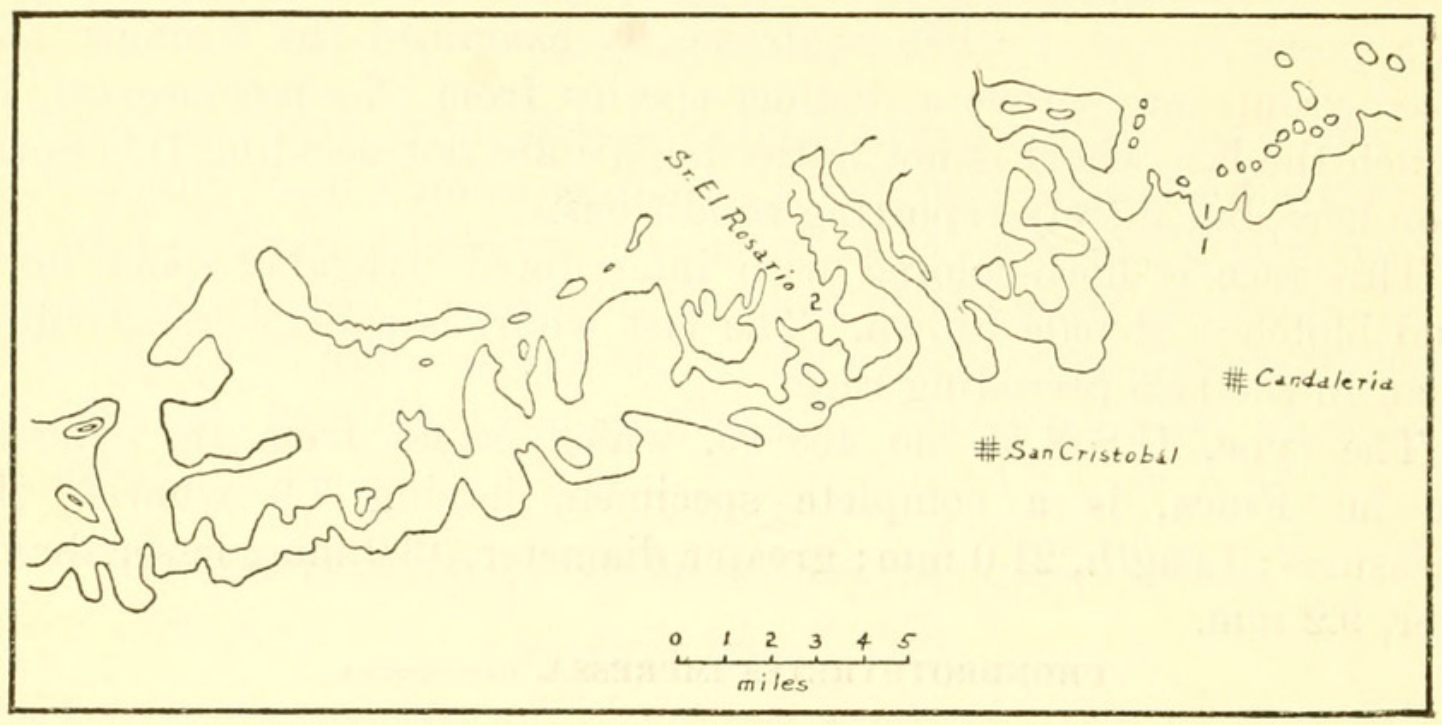

FIgUre 90.-Distribution of subspecies of Chrondrothyretes impressa: (1) peregrina; (2) rosariensis.

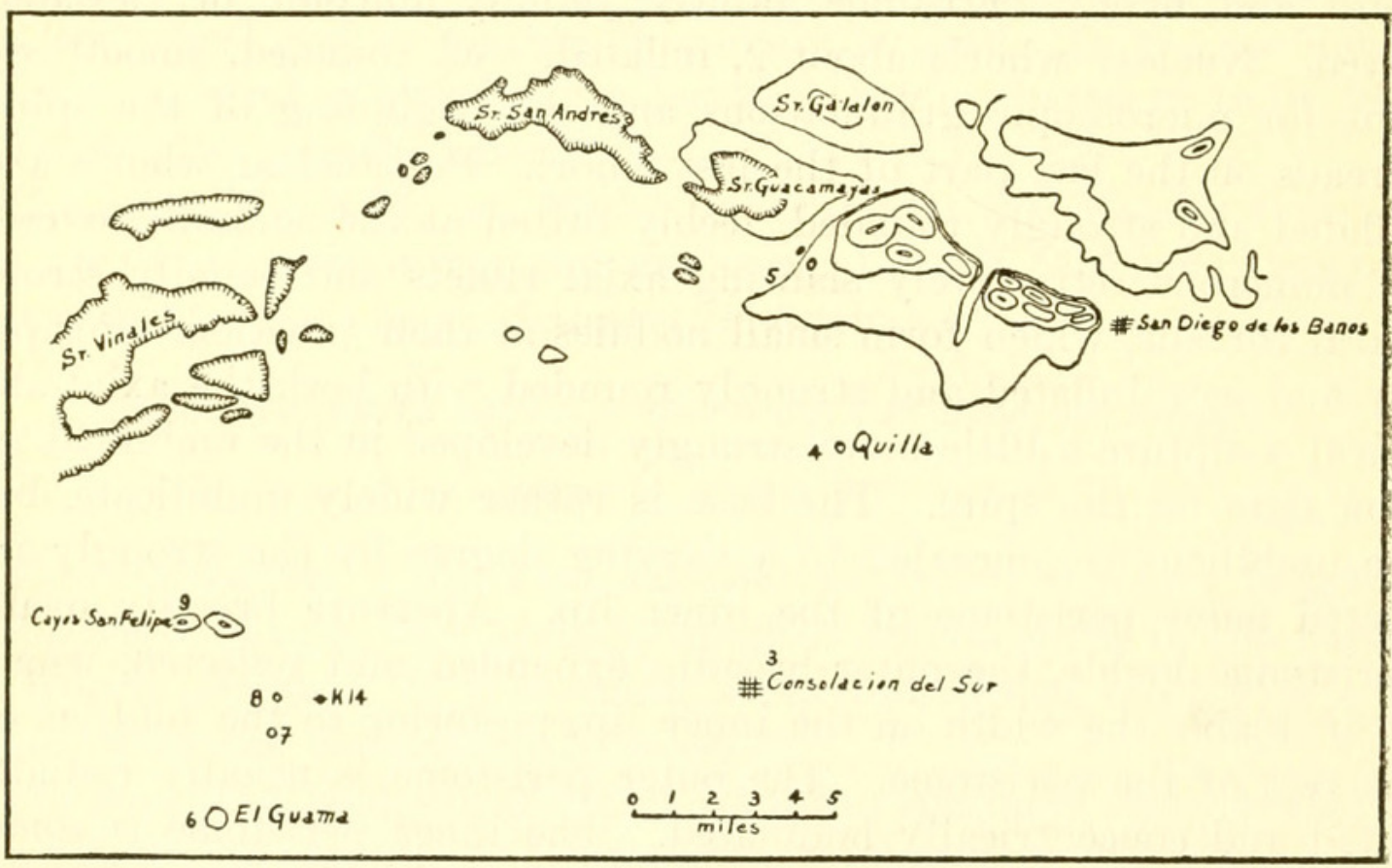

Figure 91.-Distribution of subspecies of Chondrothyretes impressa: (3) impressa; (4) solacia; (5) ornata; (6) guamensis; (7) hyans; (8) gigantea; (9) albostoma.

Mountains but so far has not been reported from the mountains themselves. Its western member is known from El Guama, and its eastern representative comes from Loma de Candelaria.

Distribution of the subspecies of $C$. impressa is shown in figures 90 and 91 . 
KEY TO THE SUBSPECIES OF CHONDROTHYRETES IMPRESSA

Peristome radiatingly rayed with brown.

Rays of outer peristome very decided.

Greater diameter more than $14 \mathrm{~mm}$

gigantea

Greater diameter less than $13 \mathrm{~mm}$.

Spiral color lines confined to posterior two-thirds of

whorls between summit and suture

ornata

Spiral color lines not confined to posterior two-thirds

of whorls between summit and suture.

Interrupted spiral lines of brown broad solacia

Interrupted spiral lines of brown not broad impressa

Rays of outer peristome not very decided.

Greater diameter more than $15 \mathrm{~mm}$ guamensis

Greater diameter less than $12 \mathrm{~mm}$.

Umbilicus with a narrow slit

hyans

Umbilicus without a narrow slit

peregrina

Peristome not radiatingly rayed albostoma

Shell interruptedly spirally banded.

Shell not interruptedly spirally banded rosariensis

CHONDROTHYRETES IMPRESSA GIGANTEA, new subspecies

Plate 18, Figure 12

This large race comes from a mogote 2 kilometers west of Kilometer 14, between Pinar del Rio and Vinales.

The type, U.S.N.M. no. 468741, a complete specimen, has 6.8 whorls and measures: Length, $24.5 \mathrm{~mm}$; greater diameter, $15.4 \mathrm{~mm}$; lesser diameter, $10.5 \mathrm{~mm}$.

Its large size, combined with the strong radiating rays of the outer peristome, distinguishes it at once from all the other known subspecies.

\section{CHONDROTHYRETES IMPRESSA ORNATA, new subspecies}

Plate 18, Figure 2

This subspecies was collected by Natenson on a mogote immediately south of Perez Rivera's house, about one and one-half miles south of the eastern end of the Sierra Guacamayas.

It is a thin-shelled race brightly banded with interrupted dark brown lines, which are confined to the posterior two-thirds of the whorls between summit and suture.

The type, U.S.N.M. no. 468938, has 4.2 whorls remaining and measures: Length, $20.3 \mathrm{~mm}$; greater diameter, $12.5 \mathrm{~mm}$; lesser diameter, $8.4 \mathrm{~mm}$. 


\section{CHONDROTHYRETES IMPRESSA SOLACIA, new subspecies}

Plate 18, Figure 3

This subspecies was collected by Natenson on Mogote de Quilla, Entronque de Herradura.

It resembles $C$. impressa ornata but has the interrupted brown spiral lines extending over the entire surface of the shell. From $C$. impressa impressa it is distinguished by having the spiral lines of brown much broader.

The type, U.S.N.M. no. 468936, a complete specimen, has 7.5 whorls and measures: Length, $20.0 \mathrm{~mm}$; greater diameter, $11.6 \mathrm{~mm}$; lesser diameter, $8.8 \mathrm{~mm}$.

\section{CHONDROTHYRETES IMPRESSA IMPRESSA, new subspecies}

Plate 18, Figure 11

In this race, which comes from the Cantera north of Consolacion del Sur, the shell is small and marked near the summit by one broad and between this and the periphery by 4 narrow interrupted spiral zones of chestnut-brown; another similar zone marks the periphery, while 5 more are present on the base. The outer peristome is fairly strongly rayed. The posterior half of the outer peristome of the inner lip is deeply inbent, plugging the umbilicus, but usually leaving a narrow chink open.

The type, U.S.N.M. no. 468740 , a perfect specimen, has 6.9 whorls and measures: Length, $19.3 \mathrm{~mm}$; greater diameter, $11.5 \mathrm{~mm}$; lesser diameter, $8.1 \mathrm{~mm}$.

\section{CHONDROTHYRETES IMPRESSA GUAMENSIS, new subspecies}

\section{Plate 18, Figure 10}

This large race was collected by Palmer and Riley at El Guama a little west of Pinar del Rio.

Its large size, combined with the faint rays of the outer peristome, easily differentiates it from the other known large $C$. impressc gigantea.

The type, U.S.N.M. no. 169928, has 4.2 whorls remaining, which measure: Length, $23.8 \mathrm{~mm}$; greater diameter, $15.5 \mathrm{~mm}$; lesser diameter, $11.5 \mathrm{~mm}$.

CHONDROTHYRETES IMPRESSA HYANS, new subspecies

Plate 18, Figure 1

In this small race the interrupted spiral color markings consist of irregular blotches that are frequently confluent; especially is this 
true on the base. The peristome is only faintly radiately rayed. Here both the axial and spiral threads become somewhat reduced on the last whorl. The reflected outer peristome leaves an open gap at the umbilicus.

This subspecies comes from the mogote southwest of Kilometer 14, between Pinar del Rio and Vinales.

The type, U.S.N.M. no. 492731, is a perfect specimen, having 6.5 whorls, and measures: Length, $19.2 \mathrm{~mm}$; greater diameter, $11.7 \mathrm{~mm}$; lesser diameter, $8.2 \mathrm{~mm}$.

CHONDROTHYRETES IMPRESSA PEREGRINA, new subspecies

Plate 18, Figure 4

This small race, which represents the easternmost member of the impressa complex, was collected by Arango at Loma de Candelaria, Pinar del Rio Province.

It resembles $C$. impressa hyans in size but has the whorls a little more inflated. It also lacks the narrow umbilical slit.

The type, U.S.N.M. no. 367890, is a complete specimen having 6.4 whorls and measures: Length, $17.8 \mathrm{~mm}$; greater diameter, $11.0 \mathrm{~mm}$; lesser diameter, $8.2 \mathrm{~mm}$.

CHONDROTHYRETES IMPRESSA ALBOSTOMA, new subspecies

Plate 18, Figure 6

This race comes from the smaller mogote of the Cayo San Felipe. It has the early whorls regularly interruptedly spirally banded with brown. On the last whorls these markings become broader and more or less axially confluent. The peristome is white. The sculpture of the last whorl is also somewhat less developed than on the preceding turns.

The type, U.S.N.M. no. 468742 , is a perfect specimen, having 6.5 whorls and measures: Length, $21.4 \mathrm{~mm}$; greater diameter, $13.5 \mathrm{~mm}$; lesser diameter, $9.3 \mathrm{~mm}$.

\section{CHONDROTHYRETES IMPRESSA ROSARIENSIS, new subspecies}

\section{Plate 18, Figure 5}

This race was collected by Cisnero, at San Cristobal in the Sierra El Rosario. It, like $C$. impressa albostoma, is white-lipped, but differs from that subspecies by lacking the numerous interrupted spiral lines and strong varicial streaks.

The type, U.S.N.M. no. 367887 , has 4.0 whorls remaining and measures: Length, $17.3 \mathrm{~mm}$; greater diameter, $11.8 \mathrm{~mm}$; lesser diameter, $8.5 \mathrm{~mm}$. 


\section{CHONDROTHYRETES DELECTABILIS, new species}

Shell small, elongate-ovate, thin, varying in color from uniform flesh-color to pale yellow with or without an axial dark zone behind the peristome and with or without interrupted spiral bands. Nuclear whorls about 2 , strongly rounded, smooth, with at least an indication of dark coloration at the suture of the beginning of the turns. Postnuclear whorls well rounded, marked by slender or fairly regular retractively curved axial riblets and spiral threads, the latter a little stronger than the axial riblets. The junction of these two elements forms slender nodules. Suture well impressed. Periphery strongly

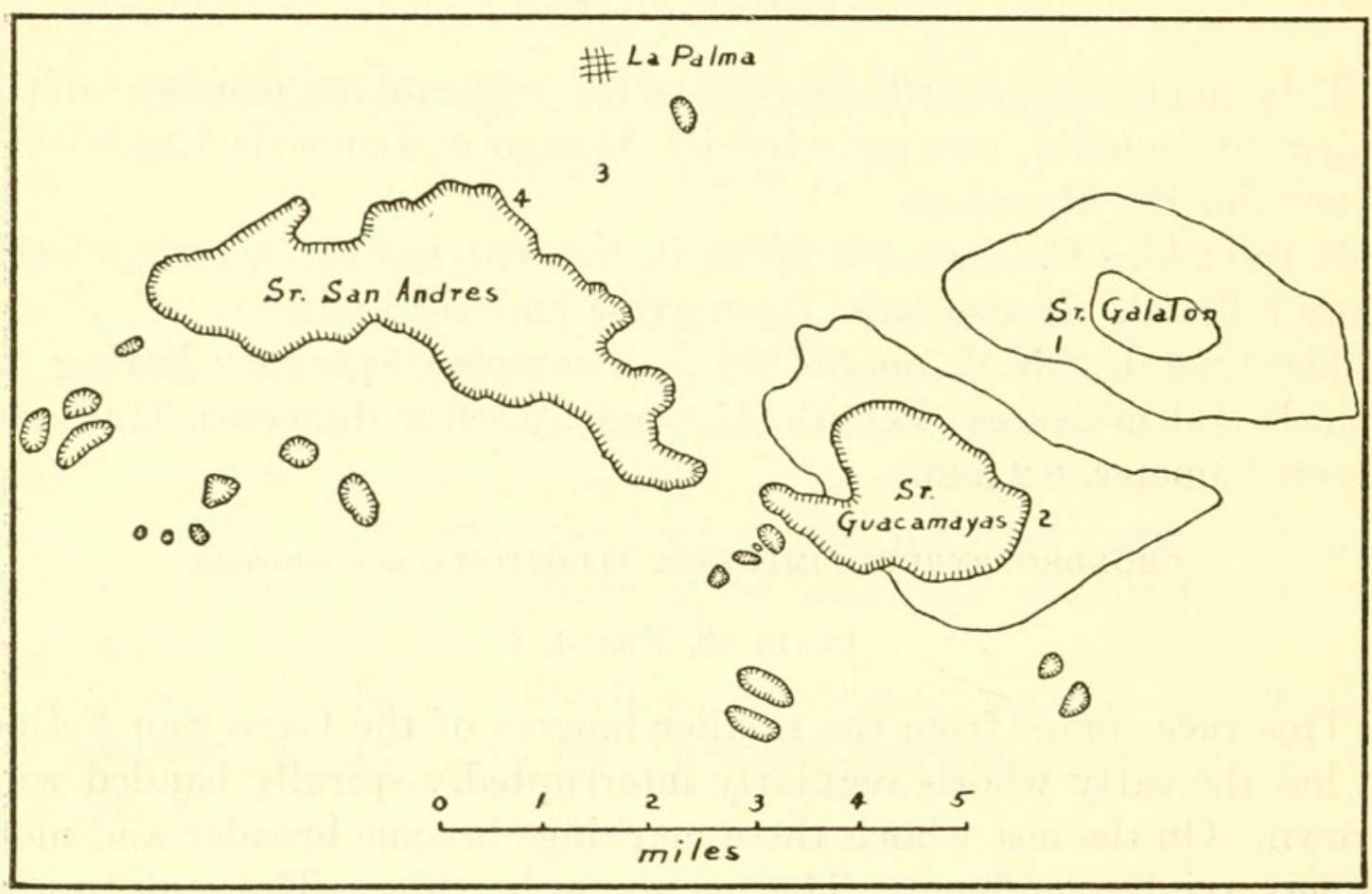

FIGURE 92.-Distribution of the subspecies of Chondrothyretes delectabilis: (1) amabilis; (2) delectabilis; (3) palmaris; (4) bellamaria.

rounded. Base marked by the same sculpture that characterizes the spire. Aperture broadly ovate; peristome double, the inner slightly exserted; the outer broadly flaringly expanded, somewhat fluted and marked by concentric lamellae with a deep cut on the middle of the inner lip posterior to which the peristome is reflected over the umbilicus, covering this as a broad flap.

The species ranges from the mogotes on the north side of the Sierra San Andrés eastward to the Mogote de Galalón. It breaks up into local races, four of which we are recognizing as subspecies.

Distribution of the subspecies of Chondrothyretes delectabilis is shown in figure 92. 
KEY TO THE SUBSPECIES OF CHONDROTHYRETES DELECTABILIS

Axial dark zone behind peristome present delectabilis Axial dark zone behind peristome absent.

Interrupted spiral bands between summit and suture 5 palmaris

Interrupted spiral bands between summit and suture 4 .

Rays on outer lip fairly strong

Rays on outer lip feeble or obsolete_-__-_-_-_-_-_-_-_-_ amabilis

CHONDROTHYRETES DELECTABILIS DELECTABILIS, new subspecies

\section{Plate 17 , Figure 1}

This race comes from Caiguanabo, the eastern part of the Sierra Guacamayas.

The type, U.S.N.M. no. 468798 , has 3.3 whorls remaining, and measures: Length, 18.4; greater diameter, $11.5 \mathrm{~mm}$; lesser diameter, $8.2 \mathrm{~mm}$.

It is easily distinguished from the other three races by the fact that here the dark axial band behind the peristome is missing. It is also more strongly spirally banded, particularly so on the back of the expanded peristome.

CHONDROTHYRETES DELECTABILIS PALMARIS, new subspecies

Plate 17, Figure 5

This race comes from the Mogote de Vegas Nuevas, 3 kilometers from La Palma.

The type, U.S.N.M. no. 468803, is a complete specimen having almost 7.0 whorls and measures: Length, $18.2 \mathrm{~mm}$; greater diameter, $11.2 \mathrm{~mm}$; lesser diameter, $7.9 \mathrm{~mm}$.

It also has the dark axial zone behind the peristome but has five slender spiral interrupted bands between the summit and suture.

CHONDROTHYRETES DELECTABILIS BELLAMARIA, new subspecies

Plate 17, Figure 2

This race comes from the Mogote Bella Maria on the north side of Sierra San Andrés near La Palma.

The type, U.S.N.M. no. 468801, has 5.5 whorls remaining and measures: Length, $20.5 \mathrm{~mm}$; greater diameter, $12.0 \mathrm{~mm}$; lesser diameter, $8.9 \mathrm{~mm}$.

Here we have a strong dark axial band behind the peristome, four interrupted slender spiral bands of brown, and rather strong rays on the outside of the outer lip. 


\section{CHONDROTHYRETES DELECTABILIS AMABILIS, new subspecies}

Plate 17, Figure 4

This race comes from the Mogote de Galalón, east of La Palma.

The type, U.S.N.M. no. 468805 , is a complete specimen having 7.0 whorls and measures: Length, $18.7 \mathrm{~mm}$; greater diameter, $11.6 \mathrm{~mm}$; lesser diameter, $7.9 \mathrm{~mm}$.

It has the dark axial zone behind the peristome and four interrupted spiral bands between the summit and suture, but here the rays on the outside of the outer lip are very feeble.

\section{CHONDROTHYRETES TENEBRATA, new species}

Shell moderately large, ovate, rather stout, varying in ground color from flesh-color and pale yellow to orange to dark brown. The early whorls usually are darker than the later, somewhat unicolor, but usually banded. The peristome varies from white to orange and may or may not be strongly rayed. Nuclear whorls almost 2, the first pale, the next very dark, somewhat inflated and strongly rounded. Postnuclear whorls inflated; the early ones slightly angulated in the middle and the later ones well rounded and marked by slender, retractively curved, axial and spiral threads, the latter of a little wider spacing than the axial. The junction of these two elements on the early whorls forms feeble nodules; on the later turns they scarcely merit that designation. Suture well constricted. The axial riblet extends strongly to the suture and gives to this the merest indication of denticulations. Periphery inflated, well rounded. Base sort, inflated, strongly rounded, and like the spire tending toward a little stronger nodulation at the junction of the axial and spiral elements. Aperture broadly oval. Peristome double, the inner slightly exserted and slightly reflected; the outer broadly flaringly expanded, somewhat fluted and marked by concentric lamellae, cut in the middle of the inner lip, the posterior part to the cut is reflected over the umbilicus which it covers. Operculum thin, corneous, covered with a heavy granular calcareous deposit, which has a somewhat fluted appearance.

The animal of $C$. tenebrata albolabris is smoky gray, a little paler on the foot and the edge of the snout; darkest on the forehead. Tentacles encircled with a flesh-colored ring at their base; the rest scarlet, with the lateral portion of the expanded tip sooty. The internal anatomy shines through behind the tentacles as a pinkish flush. Foot medially cleft; locomotion alternate.

This species ranges through the Sierra San Andrés, some of the mogotes to the south of this and eastward to Guacamayas and the mogotes north and south of this. 
It breaks up through this range into a series of subspecies, eight of which we are here characterizing.

Distribution of the subspecies of Chondrothyretes tenebrata is shown in figure 93.

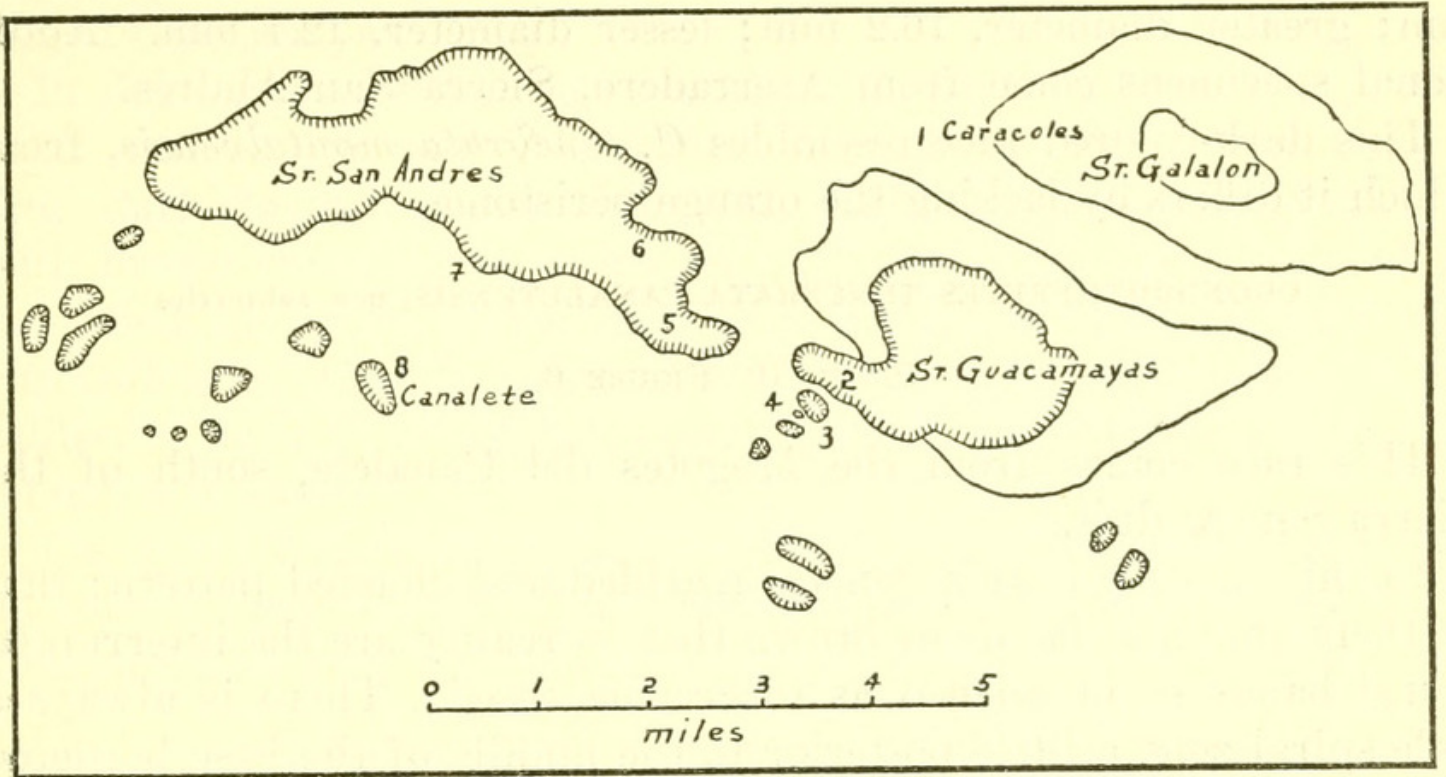

FIGURE 93.-Distribution of the subspecies of Chondrothyretes tenebrata: (1) brevior; (2) albolabris; (3) variabilis; (4) scripta; (5) tenebrata; (6) montalvensis; (7) ayuensis; (8) canaletensis.

\section{KEY TO THE SUBSPECIES OF CHONDROTHYRETES TENEBRATA}

Expanded lip strongly rayed.

Early whorls dark brown tenebrata

Early whorls not dark brown.

shell clouded and marbled.

Dark rays of outer lip exceeding in extent the light intervals. canaletensis

Dark rays of outer lip equaling in extent the light intervals_-_-_-_-_ scripta

Dark rays of outer lip less in extent than the light intervals variabilis

Shell not clouded and marbled.

Length of decollated shell more than $23 \mathrm{~mm}$ ayuensis

Length of decollated shell less than $21 \mathrm{~mm}$ brevior Expanded lip not strongly rayed.

Rays absent or obsolete.

Shell ranging from flesh-color to pale reddish brown albolabris

Shell ranging from orange to reddish brown montalvensis

\section{CHONDROTHYRETES TENEBRATA TENEBRATA, new subspecies}

\section{Plate 19, Figure 1}

Shell varying from dark orange brown to dark brown, banded to various degrees. The early whorls dark, the later a little paler; the 
back of the expanded peristome is conspicuously rayed; the inside of the peristome is pale yellow.

The type, U.S.N.M. no. 468809, comes from the Pasada de las Escaleras, Sierra San Andrés. It has 6.5 whorls, probably having lost the first half of the nuclear turn, and measures: Length, 27.7 $\mathrm{mm}$; greater diameter, $16.2 \mathrm{~mm}$; lesser diameter, $12.4 \mathrm{~mm}$. Additional specimens come from Aserradero, Sierra San Andrés.

This dark-colored race resembles $C$. tenebrata montalvensis, from which it differs by lacking the orange peristome.

CHONDROTHYRETES TENEBRATA CANALETENSIS, new subspecies

Plate 19, Figure 6

This race comes from the Mogotes del Canalete, south of the Sierra San Andrés.

In this race we have a general marbled and clouded pattern; that is, there are axial bands of brown that in reality are the interrupted spiral bands so broadened as to become fused. There is always a pale spiral zone a little posterior to the middle of the base bordered on either side by darker zones. The dark axial band behind the peristome is present, and the back of the expanded peristome is conspicuously rayed, the rays frequently being confluent. The front portion of the peristome, which is pale yellow, is also conspicuously rayed.

The type, U.S.N.M. no. 468818 , has 4.5 turns remaining and measures: Length, $23.5 \mathrm{~mm}$; greater diameter, $15.0 \mathrm{~mm}$; lesser diameter, $10.2 \mathrm{~mm}$.

The clouded marbled pattern of this race will readily distinguich it from all others.

\section{CHONDROTHYRETES TENEBRATA SCRIPTA, new subspecies}

Plate 19, Figure 2

This race was collected by Natenson on Mogote Largo, the large second mogote off the southwestern end of the Sierra Guacamayas. It resembles $C$. tenebrata canaletensis in general color scheme but the spiral bands, which are interruptedly expanded in axial series, are not axially confluent at these widened intervals. The dark rays of the outer lip equal the light intervals in extent. The shells are also larger than in $C$. tenebrata canaletensis.

The type, U.S.N.M. no. 468982, has 3.8 whorls remaining and measures: Length, $24.3 \mathrm{~mm}$; greater diameter, $16.8 \mathrm{~mm}$; lesser diameter, $12.5 \mathrm{~mm}$. 
CHONDROTHYRETES TENEBRATA VARIABILIS, new subspecies

\section{Plate 20, Figure 4}

This race was collected by Natenson on the small mogote southwest of the Mogote Largo, which lies off the southwestern end of the Sierra Guacamayas.

In this subspecies the shell averages smaller than those of $C$. tenebrata canaletensis, and is decidedly variable in color, which ranges from dark clouded chestnut-brown through various shades of orange, with brown spiral lines, which may be slender or even confluent at expanded intervals, where they may even form axial dark zones. Regardless of what the general coloration of the shell may be, the radiating dark zones of the outer lip here never equal the lighter intervals in extent.

The type, U.S.N.M. no. 493297 , has 4.0 whorls remaining, which measure: Length, $20.8 \mathrm{~mm}$, greater diameter, $14.7 \mathrm{~mm}$; lesser diameter, $10.2 \mathrm{~mm}$.

\section{CHONDROTHYRETES TENEBRATA AYUENSIS, new subspecies}

\section{Plate 20, Figure 1}

This race comes from the Ensenada de la Ayua on the south side of the Sierra San Andrés.

Shell with the early postnuclear whorls a dark orange, gradually changing to very pale orange or even flesh-color on the last whorl, unicolor or variously banded, strongly rayed on both sides of the expanded outer peristome.

The type, U.S.N.M. no. 468814, has 4.5 whorls remaining and measures: Length, $23.0 \mathrm{~mm}$; greater diameter, $16.0 \mathrm{~mm}$; lesser diameter, $11.3 \mathrm{~mm}$.

The bright orange color of this race readily distinguishes it frcm all the other subspecies.

\section{CHONDROTHYRETES TENEBRATA BREVIOR, new subspecies}

\section{Plate 20, Figure 2}

This race comes from Caracoles, north of the Sierra Guacamayas. Shell small, pale yellow or orange, with the expanded outer lip strongly rayed both in front and on the back. The dark axial zone behind the peristone is narrow, or almost absent. The shell is feebly rayed.

The type, U.S.N.M. no. 468807, is a complete specimen having 6.7 turns and measuring: Length, $20.8 \mathrm{~mm}$; greater diameter, 14.5 $\mathrm{mm}$; lesser diameter, $9.4 \mathrm{~mm}$.

The small size will readily distinguish this race from all the others. 
CHONDROTHYRETES TENEBRATA ALBOLABRIS, new subspecies

Plate 20, Figure 3

This race comes from the Sierra Guacamayas.

This subspecies has the shell orange or pale brownish orange; it has the dark band behind the peristome, which is white or almost so. The expanded outer peristome is obsoletely rayed on the front side and a little more strongly on the back.

The type, U.S.N.M. no. 468816, has 5.0 whorls remaining and measures: Length, $24.0 \mathrm{~mm}$; greater diameter, $15.8 \mathrm{~mm}$; lesser diameter, $10.8 \mathrm{~mm}$.

This race approximates $C$. tenebrata ayuensis but is a little darker in coloration and lacks the conspicuous raying of the peristome and is also smaller.

\section{CHONDROTHYRETES TENEBRATA MONTALVENSIS, new sabspecies}

\section{Plate 19, Figure 3}

This race comes from the Coral de El Montalvo, on the road to La Palma from the Sierra San Andrés.

Shell dark orange or blackish brown with the peristome orange, unicolor or banded, with or without a dark band at the summit. The dark axial band is present behind the peristome, which is but slightly rayed on the back. The front of the expanded peristome is obsoletely rayed, or if rays are present they are inconspicuous.

The type, U.S.N.M. no. 468856 , has 6.0 whorls remaining and measures: Length, $26.0 \mathrm{~mm}$; greater diameter, $16.3 \mathrm{~mm}$; lesser diameter, $11.3 \mathrm{~mm}$.

This race in general appearance approximates most nearly typical $C$. tenebrata tenebrata but can at once be distinguished from that by having the expanded peristome orange instead of pale yellow.

\section{CHONDROTHYRETES RETICULATA, new species}

Shell conic, turreted, exceedingly variable in coloration, even within the same subspecies. The shell may be pure alabaster white, pale strawcolor, yellow, orange, red, buff, brown, or even sooty brown; unicolor or banded with continuous spiral lines or zones of darker color than the ground color, or the spiral bands may be interrupted and the elements composing them may be arranged in axial series, the shell thereby appearing varicially streaked. There is usually a narrow white line at the summit. In some of the subspecies there is a dark axial zone immediately preceding the expanded peristome, which is usually white or may be faintly yellow. The raying of the outer peristome is not marked in this species, only some of the 
subspecies have this tendency. Nuclear whorls about 2, well rounded, smooth, the last portion of the last turn showing the beginning of the postnuclear sculpture. The postnuclear whorls are inflated, well rounded, appressed at the summit, which is feebly denticulated and marked by numerous, closely spaced, axial riblets and spiral threads equaling the riblets in strength. This combination gives to the surface the reticulated pattern responsible for this subspecific name. Aperture broadly ovate. Peristome double; the inner somewhat exserted and slightly reflected; the outer broadly flaringly expanded, somewhat fluted, and marked by feeble concentric lamellae. The outer peristome is cut in the middle of the inner lip, and the portion posterior to the cut is reffected over the umbilicus as a heavy callus, which also extends over the parietal wall. The breathing pore is a conspicuous perforation on the parietal wall about as far removed from the edge of the inner lip as it is from the posterior angle. The operculum is thin, paucispiral, with submarginal nucleus covered on the outside with a thin deposit of fine calcareous granules which are arranged in a somewhat radiating pattern.

The animal of $C$. reticulata encinarensis is flesh-color, with ashy suffusions. Tentacles orange, tipped with brown at the slightly expanded end; white at base. Feelers paler at edge. Foot deeply medially cleft, flesh-color. Motion of the two sides alternate.

The animal of $C$. reticulata reticulella is ashy gray with the forehead at the base of the tentacles white. The space between the tentacles is marked by numerous very fine dark dots. Tentacles orange-red, tipped with buff. Sole of foot short, light ash gray, medially cleft. Motion alternate on the two sides.

This subspecies ranges through the central part of the Organ Mountains of Pinar del Rio Province, that is, from Hoyo San Antonio through La Mina west of Pan de Azucar and south to the Kilometer 14 region between Vinales and Pinar del Rio, embracing not only the main blocks of limestone, but also the isolated lumps of the Laguna Piedras region and the blocks southwest of Vinales.

As in the case of the other widely distributed species, this complex breaks up into a series of zoogeographic races, each more or less sharply delimited in its distribution. Thirteen of these we are here designating as subspecies.

Distribution of the subspecies of $C$. reticulata is shown in figure 94 .

KEY TO THE SUBSPECIES OF CHONDROTHYRETES RETICULATA

Shell large, length more than $25 \mathrm{~mm}$.

Dark spiral band at summit present.

Axial and spiral threads fine encinarensis

Axial and spiral threads less fine costanerensis 
Dark spiral bands at summit absent.

White line at summit obsolete.

Shell large, $27.8 \mathrm{~mm}$ costanerensis

Shell medium sized, $25.2 \mathrm{~mm}$ galerensis

White line at summit not obsolete.

Whorls strongly inflated.

Shell clouded. petricola

Shell not clouded fraterna

Whorls not strongly inflated.

Shell strongly denticulated at summit reticulata

Shell not strongly denticulated at summit versicolor

Shell not large, length less than $22 \mathrm{~mm}$.

Front of outer peristome rayed. saccharinella

Front of outer peristome not rayed.

Rear of outer peristome feebly rayed.

Shell dark sooty brown reticulella

Shell not dark sooty brown.

Body of uniform flesh-color pellucida

Body not of uniform flesh-color.

Last whorl banded.

Shell reddish brown scrobicula

Shell variously colored petricolella

Rear of outer peristome not feebly rayed fratercula

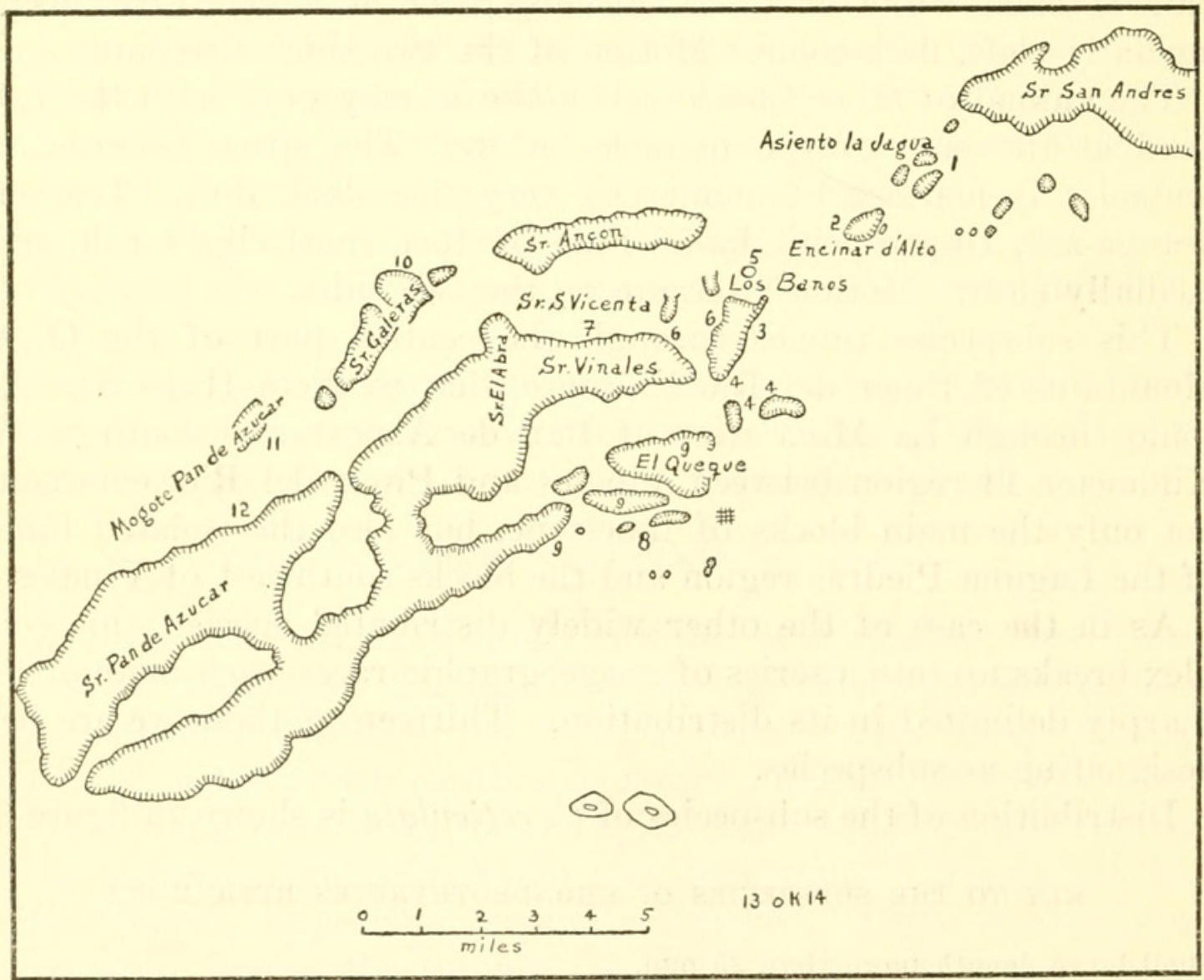

FIGURE 94.-Distribution of the subspecies of Chondrothyretes reticulata: (1) scrobicula; (2) encinarensis; (3) petricolella; (4) petricola; (5) reticulella; (6) reticulata; (7) costanerensis; (8) fratercula; (9) fraterna; (10) galerensis; (11) saccharinella; (12) versicolor; (13) pellucida. 


\section{CHONDROTHYRETES RETICULATA ENCINARENSIS, new subspecies}

\section{Plate 21, Figure 2}

This race is confined to the mogote known as La Mina or Encinar de Alto. It is the easternmost of the larger races. It is light in color, ranging from flesh-color to pale orange, never banded, except for the moderately broad zone immediately below the white line at the summit. This dark band, combined with the absence of other bandings, readily distinguishes this from all the other races, except an occasional specimen of $C . r$. costanerensis.

The type, U.S.N.M. no. 468984, a complete specimen, has 7.0 whorls and measures: Length, $26.0 \mathrm{~mm}$; greater diameter, $16.7 \mathrm{~mm}$; lesser diameter, $11.3 \mathrm{~mm}$.

\section{CHONDROTHYRETES RETICULATA COSTANERENSIS, new subspecies}

Plate 21, Figure 8

This race occupies the Costanera San Vicente and the Costanera del Abra. Here again we have an enormous range of color variation, which extends from white to straw-color, to yellow, to orange, to brown; the shell may be mottled, banded, or flecked, unicolor or interruptedly banded. We find here also an extension of the La Mina features, namely, a dark spiral band immediately below the white line at the summit. This, however, is not constant but appears to be present in about one-third of the shells. A dark varicial line behind the peristome is present in most specimens. The expanded peristome itself is not rayed, or bears the merest indication of rays at its base on the outside. Specimens from Hoyo de Magdalena are redder than those of other parts of the range of this subspecies.

The type, U.S.N.M. no. 468900, comes from Costanera San Vicente. This is a complete specimen having 6.3 whorls and measures: Length, $27.8 \mathrm{~mm}$; greater diameter, $17.7 \mathrm{~mm}$; lesser diameter, $12.6 \mathrm{~mm}$.

\section{CHONDROTHYRETES RETICULATA GALERENSIS, new subspecies}

\section{Plate 20, Figure 10}

In this race, which occupies the western end of the Sierra Galera, the shells are of medium size and thin, and they vary from pale orange to brown. The usual white line at the summit is scarcely indicated, and the peristome is free of rays, except for mere indications.

The type, U.S.N.M. no. 492895 , has 4.3 whorls remaining and measures: Length, $25.2 \mathrm{~mm}$; greater diameter, $15.9 \mathrm{~mm}$; lesser diameter, $12.2 \mathrm{~mm}$. 


\section{CHONDROTHYRETES RETICULATA PETRICOLA, new subspecies}

Plate 20, Figure 9

This subspecies ranges through the Sierra Chorrera and the Mogotes Marmol of the Laguna Piedras. The race is characterized by its thin shell, tawny ground color, and the fine interrupted spiral lines, which are arranged in axial series, thus giving to the shell a decidedly clouded effect. The area immediately behind the peristome forms a dark axial zone.

The type, U.S.N.M. no. 468906, a complete specimen from the Sierra Chorrera, has 7.1 whorls remaining and measures: Length, $28.9 \mathrm{~mm}$; greater diameter, $17.2 \mathrm{~mm}$; lesser diameter, $13.3 \mathrm{~mm}$.

\section{CHONDROTHYRETES RETICULATA FRATERNA, new subspecies}

Plate 20, Figure 11

This race, which comes from El Cuajani, Mogotes dos Hermanos, El Queque, is large and thin shelled and varies in color from white through orange and reddish to brown. It is not clouded. There is a slender, white, finely denticulated line at the summit not bordered with a dark line. The outer peristome is free of rays on both sides.

The type, U.S.N.M. no. 492885, comes from El Queque. It has 7.0 whorls and measures: Length, $28.6 \mathrm{~mm}$; greater diameter, $17.5 \mathrm{~mm}$; lesser diameter, $13.2 \mathrm{~mm}$.

CHONDROTHYRETES RETICULATA RETICULATA, new subspecies

Plate 21, Figure 6

The typical race ranges through the limestone bluffs of Banos San Vicente, the Ensenada de los Banos, and the Puerta de la Ancon. This race is also very variable in color but dark as compared with the other large races, brown being the prevailing coloration. The finely denticulated white line at the summit is very marked in this race, and interrupted spiral bands are fairly regularly arranged in axial series, giving this a more or less varicially streaked effect. The peristome is not rayed.

The type, U.S.N.M. no. 492910, comes from Banos San Vicente. It has 6.0 whorls remaining and measures: Length, $27.5 \mathrm{~mm}$; greater diameter, $16.4 \mathrm{~mm}$; lesser diameter, $12.6 \mathrm{~mm}$.

\section{CHONDROTHYRETES RETICULATA VERSICOLOR, new subspecies}

Plate 21, Figure 4

This subspecies occupies the north slope of Pan de Azucar. It is a dark race, frequently with a light base and a broad median spiral band. The whorls are not as strongly inflated as in some of the 
other races and a white line at the summit is indicated. The summit of the whorls is not strongly denticulated. The front and back of the expanded peristome are not rayed.

The type, U.S.N.M. no. 492877, comes from the western end of Pan de Azucar. It is a complete specimen having 6.8 whorls and measuring: Length, $27.8 \mathrm{~mm}$; greater diameter, $16.7 \mathrm{~mm}$; lesser diameter, $12.7 \mathrm{~mm}$.

CHONDROTHYRETES RETICULATA SACCHARINELLA, new subspecies

Plate 21, Figure 1

This subspecies comes from Mogote Pan de Azucar, that conspicuous block of limestone lying a couple of miles north of the Sierra de Chichones. This is a diminutive race, very similar to $C$. reticulata versicolor, which has the peristome both on the front and back conspicuously rayed. It also has a denticulated white line at the summit.

The type, U.S.N.M. no. 492884, has 4.8 whorls remaining and measures: Length, $21.0 \mathrm{~mm}$; greater diameter, $13.8 \mathrm{~mm}$; lesser diameter, $10.7 \mathrm{~mm}$.

CHONDROTHYRETES RETICULATA RETICULELLA, new subspecies

Plate 20, Figure 7

This diminutive race is confined to a small mogote on Martinez's place at Banos San Vicente, which stands at some distance from the main range. It is a very dark chestnut-brown race, with a conspicuous denticulated zone of white at the summit. The peristome and parietal callus are also white without rays.

The type, U.S.N.M. no. 474197, is a complete specimen having 6.3 whorls and measuring: Length, $18.0 \mathrm{~mm}$; greater diameter, 11.6 $\mathrm{mm}$; lesser diameter, $8.6 \mathrm{~mm}$.

Very dark forms of $C$. reticulata petricolella resemble this in coloration, but they are a little more finely sculptured and never so dark.

CHONDROTHYRETES RETICULATA PELLUCIDA, new subspecies

Plate 20, Figure 6

This small race was taken on the second mogote on the right side of Kilometer 14 on the road between Pinar del Rio and Vinales. It is pale yellow, with white denticulations at the summit and white peristome. In some specimens faint brown spiral lines are indicated, and some individuals also show an axial dark band behind the peristome. 
The type, U.S.N.M. no. 468916 , is a complete specimen having 6.5 whorls. It measures: Length, $21.4 \mathrm{~mm}$; greater diameter, $13.3 \mathrm{~mm}$; lesser diameter, $10.0 \mathrm{~mm}$.

\section{CHONDROTHYRETES RETICULATA SCROBICULA, new subspecies}

Plate 21, Figure 3

This race comes from a small mogote known as Hoyos de San Antonio Asiento de la Jagua. It is a small race, orange in color, with white denticulations at the summit and the spaces between these brown. The peristome is slightly rayed on the back. There is also a feeble dark axial zone behind the peristome.

The type, U.S.N.M. no. 468914, has 5.0 whorls remaining and measures: Length, $20.4 \mathrm{~mm}$; greater diameter, $12.8 \mathrm{~mm}$; lesser diameter, $10.2 \mathrm{~mm}$.

CHONDROTHYRETES RETICULATA PETRICOLELLA, new subspecies

Plate 20, Figure 5

Under this name we shall combine the small shells occupying the Mogotes Piedra Laguna, as well as those that border the road from Vinales to the Puerta del Ancon. In the main this race resembles $C$. r. petricola, but it is very variable in color, ranging in ground color from flesh-color to pale brown, with the base frequently banded and the rest of the shell marked by fine spiral lines, which are also frequently arranged in axial series.

The type, U.S.N.M. no. 468908, comes from Fogon de los Negros from the northern part of the Laguna Piedras. It is a complete specimen having 7.0 whorls and measuring: Length, $20.2 \mathrm{~mm}$; greater diameter, $12.4 \mathrm{~mm}$; lesser diameter, $8.7 \mathrm{~mm}$.

CHONDROTHYRETES RETICULATA FRATERCULA, new subspecies

Plate 20, Figure 8

This race occupies the small mogotes between Vinales and the dos Hermanos, etc., including Mogote Vigil and Mogote la Feita.

The shells vary from pale chestnut-brown to sooty brown, with the peristome white on both sides. The dark forms seem conspicuously marked by the slender denticulated white line at the summit.

The type, U.S.N.M. no. 492893, comes from the Mogote la Feita. It has 3.6 whorls remaining and measures: Length, $17.6 \mathrm{~mm}$; greater diameter, $12.8 \mathrm{~mm}$; lesser diameter, $9.1 \mathrm{~mm}$. 
Shell elongate-ovate, varying in color from flesh-color through straw-color to pale orange and even pale brown in some individuals; the last whorl is always paler than the rest; the shell may have axial varicial streaks of a little darker coloration than the ground color. In two of the known races there is an orange blotch behind the peristome. Peristome white. Nuclear whorls almost 2, forming a somewhat truncated apex, strongly rounded, smooth except the last portion of the last turn, which shows the beginning of the postnuclear sculpture. Postnuclear whorls inflated, strongly rounded, marked by slender, retractively slanting, axial riblets, which are stronger on the early turns than those succeeding them, becoming decidediy enfeebled on the last whorl. The spiral sculpture consists of slender threads a little stronger than the axial. The intersection of the axial riblets and spiral threads form slender nodules on the early turns, while the spaces enclosed between them are rectangular pits. On the last whorl, however, the nodules are absent and the pits reduced to fine malleations. Suture well constricted. Periphery of the last whorl inflated, strongly rounded. Base short, inflated, strongly rounded, marked by the continuations of the axial riblets and spiral threads. The spiral threads and axial riblets are a little stronger near the umbilicus than on the posterior half of the base, forming here weak nodules at their junction. Aperture broadly oval; peristome double; the inner heavy and broadly expanded, covering two-thirds of the outer. The outer is expanded and reflected, forming a sinus at the posterior angle, the part that projects beyond the inner slightly fluted at the edge and marked by concentric lines of growth; posterior to the notch of the inner lip, the outer peristome is reflected as a broad white callus over the umbilicus, which it completely covers, extending a little less broadly upon the parietal wall, where it is appressed to the preceding turn. The breathing pore is conspicuous on the parietal wall about as far removed from the edge of the outer lip as it is from the posterior angle. Operculum thin, paucispiral, with almost submarginal nucleus, covered on the outside with a thin deposit of fine calcareous granules, which form a somewhat radiating pattern.

Gundlach" says of the animal of incrassata: "Animal grey, eye ring and edge of operculm whitish. Antennae beautifully coral colored, trending toward saffron-yellow. On the sides of the foot are spots which are composed of elevated white dots."

Chondrothyretes incrassata is distinguished from $C$. reticulata by its much less strongly reticulated sculpture and from $C$. cerina by

4 Malakozool. Blätter, vol. 10, p. 183, 1862. 
having this sculpture stronger and especially by having the inner peristome much expanded and thickened and the outer separated from

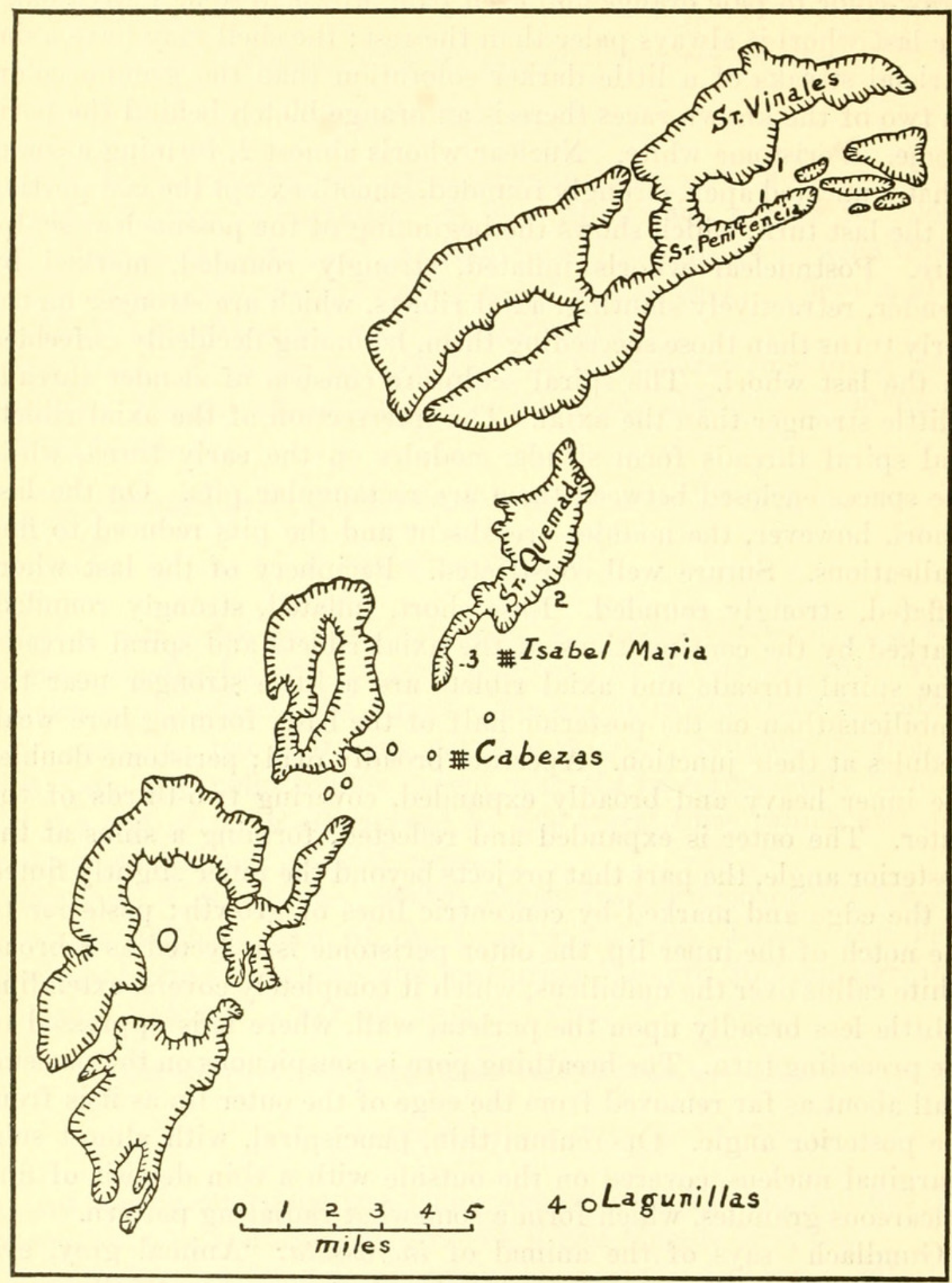

FIgURE 95.-Distribution of the subspecies of Chondrothyretes incrassata: (1) incrassata; (2) subincrassata; (3) aurantiaca; (4) fumata.

the parietal callus by an inbent channel at the posterior angle, causing the outer peristome to project at a point.

Distribution of the subspecies of $C$. incrassata is shown in figure 95 . 
KEY TO THE SUBSPECIES OF CHONDROTHYRETES INCRASSATA

Orange blotch behind peristome present.

Length of shell more than $25 \mathrm{~mm}$ aurantiaca

Length of shell less than $22 \mathrm{~mm}$ fumata

Orange blotch behind peristome absent.

Sculpture feeble incrassata

Sculpture not feeble subincrassata

\section{CHONDROTHYRETES INCRASSATA AURANTIACA, new subspecies}

Plate 22, Figure 5

The mogotes between Cabezas and Isabel Maria and the Sierra Quemada harbor a race that about equals $C$. incrassata incrassata in size and sculpture. The shells, however, are marked with a conspicuous orange blotch behind the peristome. To this race we have given the above name.

The type, U.S.N.M. no. 367872, which comes from Mogote Isabel Maria, is an almost perfect specimen. It has 6.0 whorls and measures: Length, $27.2 \mathrm{~mm}$; greater diameter, $17.8 \mathrm{~mm}$; lesser diameter, $13.8 \mathrm{~mm}$.

\section{CHONDROTHYRETES INCRASSATA FUMATA, new subspecies}

Plate 22, Figure 8

This diminutive race resembles $C$. incrassata aurantiaca, from which its small size at once distinguishes it. It comes from Lagunillas, which lies halfway between the range $C$. incrassata aurantiaca and the south coast.

The type, U.S.N.M. no. 468800, has 5.4 whorls remaining and measures: Length, $21.3 \mathrm{~mm}$; greater diameter, $12.7 \mathrm{~mm}$; lesser diameter, $9.4 \mathrm{~mm}$.

\section{CHONDROTHYRETES INCRASSATA INCRASSATA (Wright) Pfeiffer}

\section{Plate 22, Figure 7}

1862. Chondropoma incrassatum (Wright) Pfeiffer, Malakozool. Blätter, vol. 10, pp. $182-183$.

This subspecies occupies the Sierra Vinales and part of the Sierra Penitencia and is distinguished from $C$. incrassata subincrassata, the race south of it, by having a little heavier shell, paler coloration, and feebler sculpture, and by being less frequently marked by spiral color lines.

The specimen figured, one of a series of topotypes, U.S.N.M. no. 468944, was collected by Wright at Vinales. It is a perfect specimen having 6.8 whorls and measuring: Length, $29.3 \mathrm{~mm}$; greater diameter, $19.5 \mathrm{~mm}$; lesser diameter, $14.6 \mathrm{~mm}$. 
CHONDROTHYRETES INCRASSATA SUBINCRASSATA, new subspecies

Plate 22, Figure 9

This race we have from the Sierra Quemada south of the range of the typical $C$. incrassata incrassata, and from the Mogote Caoba near this. It has the shell thinner and considerably more strongly sculptured than the typical form.

The type, U.S.N.M. no. 468945, comes from the Sierra Quemada. It has 5.5 whorls remaining and measures: Length, $30.3 \mathrm{~mm}$; greater diameter, $19.4 \mathrm{~mm}$; lesser diameter, $14.4 \mathrm{~mm}$.

\section{CHONDROTHYRETES CERINA, new species}

Shell broadly ovate, wax yellow, sometimes pale orange or chestnut-brown, or even purplish, unicolor, or marked with axial streaks of a darker shade. Nuclear whorls 2, the first smooth, the second showing the beginning of the postnuclear sculpture at its termination. Postnuclear whorls inflated, strongly rounded, marked on the early turns by retractively slanting axial riblets and spiral threads of almost the same strength; on the later turns these become less conspicuous and in one of the races quite obsolete on the last whorl. The base is short, strongly rounded, and sculptured like the posterior portion of the last turn. A perture broadly ovate; peristome double, the inner reflected over the outer and adnate to it; the outer is moderately, strongly expanded and considerably thickened; the inner lip is reflected over anterior to the cut, and covers the umbilicus. It is not distinctly angulated as in some of the other species; on the parietal wall it extends over the preceding turn. The outer peristome does not project as a conspicuous auricle at the posterior angle. Breathing pore on the parietal wall a little anterior to the posterior angle of the aperture and a little within the peristome. Operculum with almost submarginal nucleus and a considerably thickened calcareous deposit on the last turn.

This species occupies the region between Vinales and the Sierra del Infierno, extending southwest to Santo Tomas, Hoyo del Guama, and to the Ensenada Pan de Azucar, and across the Sierra Martillo, breaking up into a number of subspecies, which are here described.

The shells of this species can readily be distinguished from its nearest relative, $C$. incrassata (Wright), by having the auricle at the posterior angle of the aperture almost absent and by having the outer peristome of the inner lip anterior to the notch not expanded, but forming an almost straight thickened columella, while in incrassata it always projects as a sharp element. $C$. incrassata also has the inner peristome much more thickened and much broader.

The animal of $C$. cerina subcerina is short, ashy gray, with the head adjoining the tentacles, a little paler, which is also the case at 
the tip of the snout. The tentacles are coral-red, tipped with brown. The sole of foot is a little paler than the sides of the body, deeply medially cleft; the motion of the two sides is alternate.

Distribution of the subspecies of $C$. cerina is shown in figure 96.

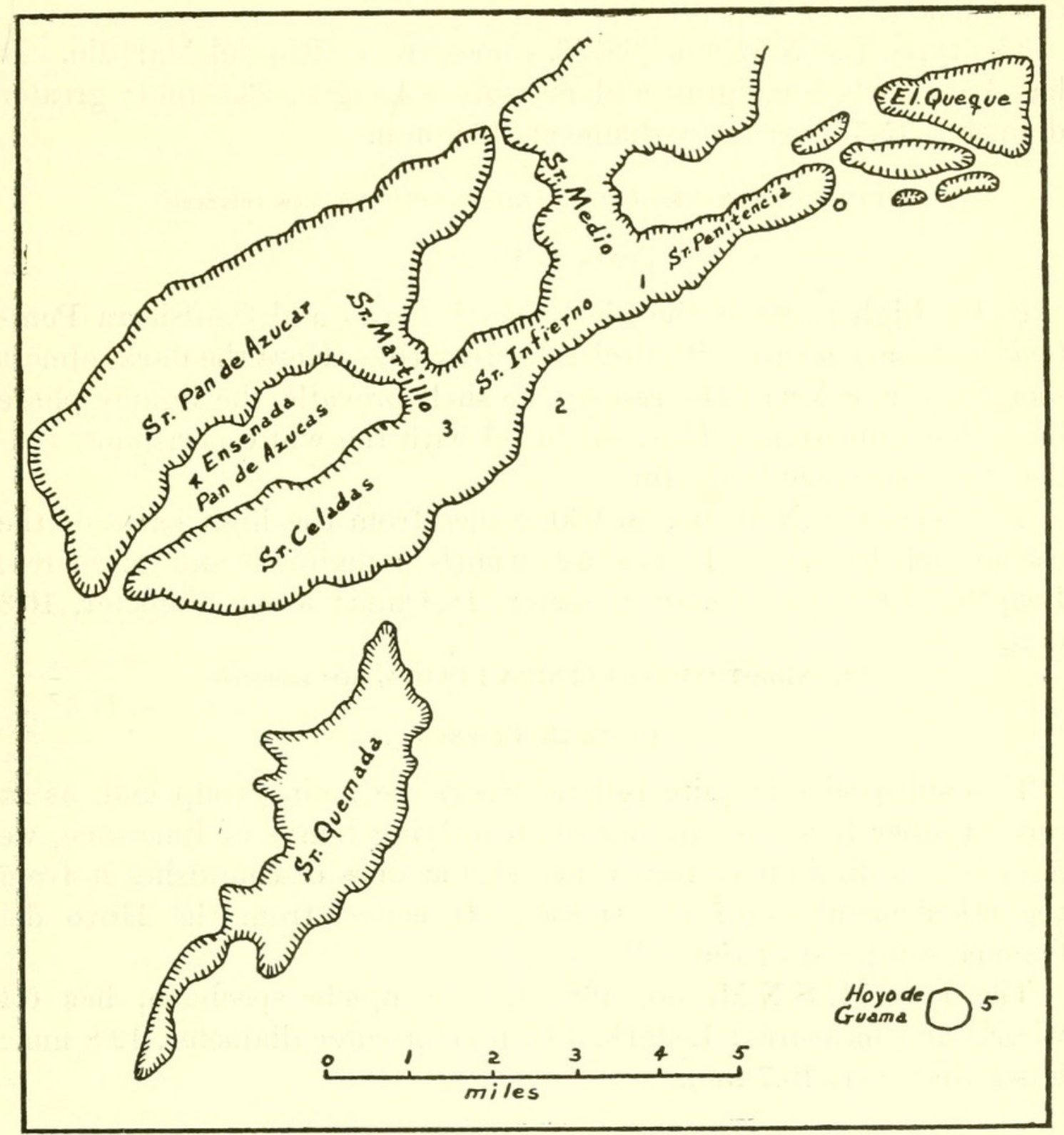

FIGURE 96.-Distribution of the subspecies of Chondrothyretes cerina: (1) roseoapicata; (2) cerina; (3) polita; (4) subcerina; (5) puella.

\section{KEY TO THE SUBSPECIES OF CHONDROTHYRETES CERINA}

Axial and spiral sculpture obsolete on last turn polita Axial and spiral sculpture not obsolete on last turn.

Apex rose-color roseoapicata Apex not rose-color.

Shell less than $22 \mathrm{~mm}$ longpuella

Shell more than $25 \mathrm{~mm}$ long.

Sculpture of last whorl feeble cerina

Sculpture of last whorl not feeble subcerina 


\section{CHONDROTHYRETES CERINA POLITA, new subspecies}

Plate 23, Figure 2

This race comes from the Sierra Martillo. It resembles typical $C$. cerina cerina but has the sculpture of the last whorl reduced to obsoleteness.

The type, U.S.N.M. no. 468598, comes from Sitio del Martillo. It has 4.5 whorls remaining and measures: Length, $23.8 \mathrm{~mm}$; greater diameter, $15.5 \mathrm{~mm}$; lesser diameter, $13.2 \mathrm{~mm}$.

\section{CHONDROTHYRETES CERINA ROSEOAPICATA, new subspecies}

Plate 23, Figure 9

In the high parts of the Sierra del Infierno and the Sierra Penitencia we have a race with decidedly rosy tip. Here the dark, almost sooty-brown, color of the rest of the shell prevails, the lighter phase being less numerous. This, combined with the white peristome, renders this race very beautiful.

The type, U.S.N.M. no. 468960 , comes from the high parts of the Sierra del Infierno. It has 5.4 whorls remaining and measures: Length, $31.6 \mathrm{~mm}$; greater diameter, $18.9 \mathrm{~mm}$; lesser diameter, 16.3 $\mathrm{mm}$.

\section{CHONDROTHYRETES CERINA PUELLA, new subspecies}

Plate 23, Figure 5

This subspecies is quite isolated from the main group and, as in certain other forms occupying small offlying lumps of limestone, we have here a diminutive race whose size at once distinguishes it from the other members of the species. It comes from the Hoyo del Guama, southeast of Santo Tomas.

The type, U.S.N.M. no. 468964, a complete specimen, has 6.4 whorls and measures: Length, $19.5 \mathrm{~mm}$; greater diameter, $12.8 \mathrm{~mm}$; lesser diameter, $10.7 \mathrm{~mm}$.

\section{CHONDROTHYRETES CERINA CERINA, new subspecies}

Plate 23, Figure 10

This subspecies ranges through the lower reaches of the Sierra del Infierno and the adjacent mogotes.

It is quite variable in size, ranging from 24 to $30 \mathrm{~mm}$ in length. In color it also ranges through everything except the roseoapicate form. In sculpture it stands midway between $C$. cerina polita, which has the last whorl obsoletely marked, and $C$. cerina subcerina, which is most strongly sculptured.

The type, U.S.N.M. no. 367874, a large complete individual from Sitio del Infierno, Sierro del Infierno, has 5.5 whorls and measures: 
Length, $27.2 \mathrm{~mm}$; greater diameter, $17.0 \mathrm{~mm}$; lesser diameter, 14.8 $\mathrm{mm}$.

CHONDROTHYRETES CERINA SUBCERINA, new subspecies

Plate 23, Figure 8

This race extends through the Ensenada Pan de Azucar, the large embayment in the western end of the Organ Mountains. It is the most strongly sculptured subspecies known, recalling weakly marked $C$. reticulata, but at once distinguished from this by the character of the peristome.

The type, U.S.N.M. no. 367875 , has 4.5 whorls remaining and measures: Length, $27.0 \mathrm{~mm}$; greater diameter, $16.9 \mathrm{~mm}$; lesser diameter, $14.0 \mathrm{~mm}$.

CHONDROTHYRETES BARBOURI, new species

Shell large and stout, varying in color from flesh-color through yellow and orange to brown; unicolor or marked with spiral lines of brown; peristome white, sometimes partly rayed on the back. Nuclear whorls about 2, well rounded, marked only by incremental lines. Postnuclear whorls somewhat inflated, well rounded, marked by rather distantly spaced spiral threads and on the early postnuclear whorls by axial threads of almost the same strength, which rapidly decrease in strength and become obsolete as the shell increases its whorls. Suture well impressed, not denticulated. Aperture broadly ovate, slightly angulated at the posterior angle; peristome double, the inner, which is slightly exserted, extends a little above the broadly expanded, somewhat radially fluted and concentrically feebly laminated outer, which has the inner lip cut in the middle and the posterior half reflected over the umbilicus, which it completely covers.

The species ranges through the Organ Mountains about Luis Lazo and eastward through Sumidero to Cabezas and some of the mogotes adjacent to this.

\section{KEY TO THE SUBSPECIES OF CHONDROTHYRETES BARBOURI}

Shell predominantly brown

barbouri

Shell predominantly pale. itineraria

\section{CHONDROTHYRETES BARBOURI BARBOURI, new subspecies}

Plate 21, Figure 5

This is the large brown race that occupies the high mountains of the Sierra San Carlos and the Sierra Acostas all around Luis Lazo and northeastward through the Sierra Sumidero.

C. barbouri barbouri is distinguished from the other subspecies by being larger and heavier and in having the brown color predomi- 
nant. Spiral color bands here are also less frequently met with than in $C$. barbouri itineraria.

The type, U.S.N.M. no. 474199, comes from Luis Lazo and has 5.5 whorls remaining, which measure: Length, $34.2 \mathrm{~mm}$; greater diameter, $21.5 \mathrm{~mm}$; lesser diameter, $16.2 \mathrm{~mm}$.

\section{CHONDROTHYRETES BARBOURI ITINERARIA, new subspecies}

Plate 21, Figure 7

This subspecies extends through the mogotes along the roadside to the east and west of Cabezas. It is smaller, thinner, paler, and almost always spirally banded.

The type, U.S.N.M. no. 499589, comes from the first mogote on the northwest side of the road east of Cabezas. It has 5.8 whorls remaining and measures: Length, $28.0 \mathrm{~mm}$; greater diameter, 16.4 $\mathrm{mm}$; lesser diameter, $12.5 \mathrm{~mm}$.

\section{CHONDROTHYRETES GUNDLACHI (Arango)}

Shell rather large, ovate-conic, varying in ground color from flesh-color through buff to pale orange, with or without a darker zone behind the peristome and with or without interrupted spiral bands. Nuclear whorls about 1.5, inflated, well rounded, smooth except for incremental lines. Postnuclear whorls well rounded, marked by slender, retractively curved, axial threads and rather stronger spiral threads, the combination of which forms a somewhat fenestrated pattern, while the junction of these elements forms slender nodules. The spiral threads frequently are conspicuously white in the typical race. Suture well constricted. Periphery of the last whorl inflated, well rounded. Base short, well rounded, and marked like the spire. Aperture broadly ovate. Peristome double; the inner slightly exserted and somewhat reflected, the outer broadly flaringly expanded, fluted and marked with concentric lamellae, cut on the middle of the inner lip with the posterior part reflected as a broad callus, which closes the umbilicus. The parietal wall is covered with a broadly expanded outer peristome. The breathing pore is on the parietal wall near the posterior angle of the aperture. Operculum with 3.5 whorls, the last covered with a heavy deposit of calcareous granules, which have a somewhat fluted appearance.

This species ranges from the Sierra de Paso Real Guane eastward through the Sierra de Guane through Portales through the Puerta de la Murallia.

We are recognizing five zoogeographic races, which we are designating as subspecies.

Distribution of the subspecies of $C$. gundlachi is shown in figure 97. 


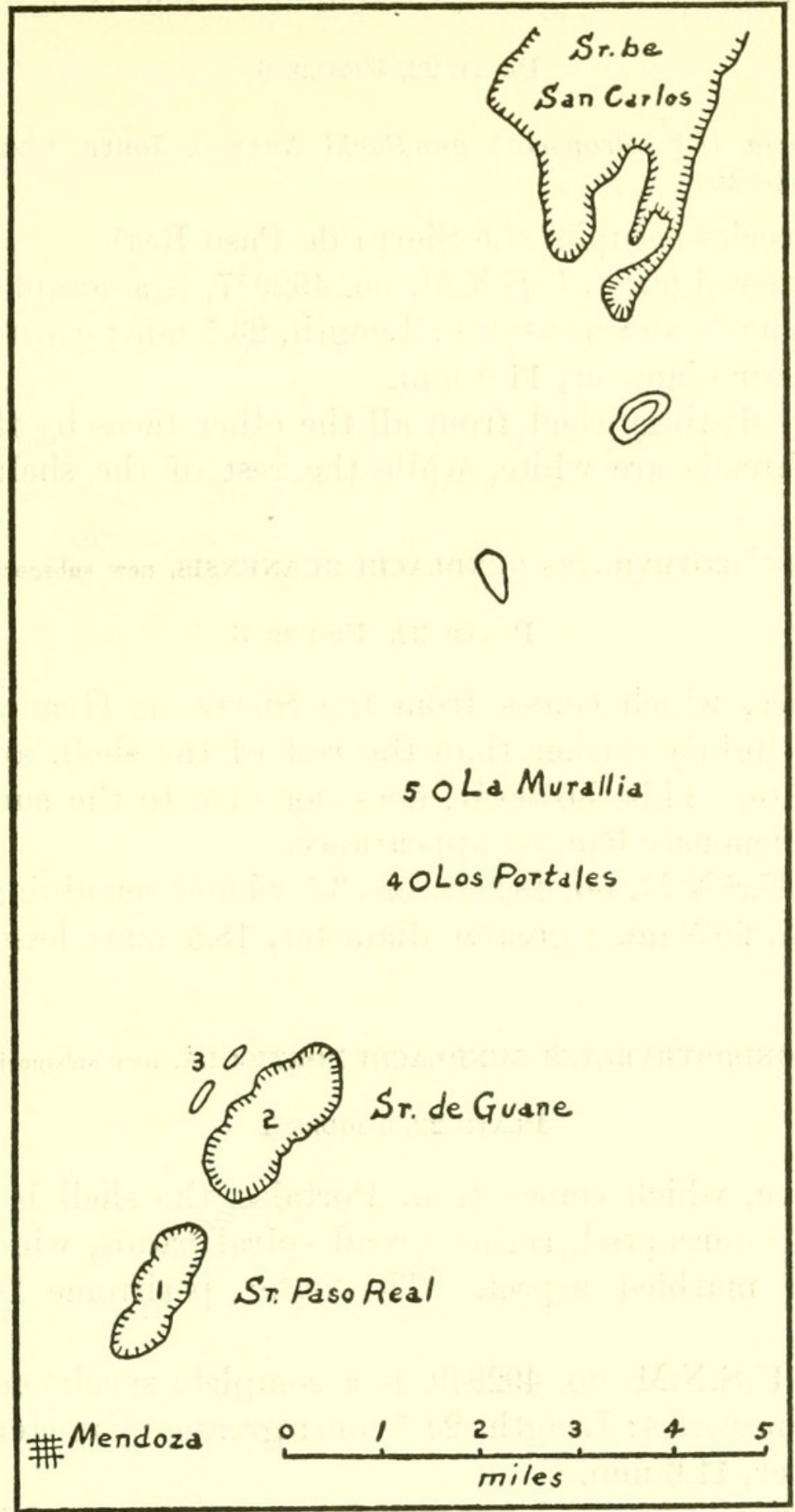

Figure 97.-Distribution of the subspecies of Chondrothyretes gundlachi: (1) gundlachi; (2) guanensis; (3) deviata; (4) porticola; (5) murallensis.

\section{KEY TO THE SUBSPECIES OF CHONDROTHYRETES GUNDLACHI}

Ground color of shell red or reddish.

Spiral threads conspicuously whitegundlachi

Spiral threads not conspicuously white guanensis Ground color of shell not red or reddish.

Ground color of shell yellowish or white.

Shell strongly spirally banded.

Shell mottled and clouded porticola

Shell not mottled and clouded murallensis Shell feebly or not spirally banded. deviata 


\section{CHONDROTHYRETES GUNDLACHI GUNDLACHI (Arango)}

\section{Plate 22, Figure 6}

1862. Cyclostoma (Chondropoma) gundlachi Arango, Journ. Conchyl., vol. 10, pp. $408-409$.

This subspecies occupies the Sierra de Paso Real.

The specimen figured, U.S.N.M. no. 492947, is a complete specimen having 7.0 whorls and measures: Length, $23.5 \mathrm{~mm}$; greater diameter, $15.8 \mathrm{~mm}$; lesser diameter, $11.0 \mathrm{~mm}$.

It is easily distinguished from all the other races by the fact that the spiral threads are white, while the rest of the shell is dark in color.

\section{CHONDROTHYRETES GUNDLACHI GUANENSIS, new subspecies}

\section{Plate 22, Figure 3}

In this race, which comes from the Sierra de Guane, the spiral threads are slightly darker than the rest of the shell, and the peristome is white. This, however, does not give to the surface of the shell a conspicuously banded appearance.

The type, U.S.N.M. no. 492948, has 3.5 whorls remaining and measures: Length, $26.5 \mathrm{~mm}$; greater diameter, $18.8 \mathrm{~mm}$; lesser diameter, $13.3 \mathrm{~mm}$.

\section{CHONDROTHYRETES GUNDLACHI PORTICOLA, new subspecies}

\section{Plate 22, Figure 1}

In this race, which comes from Portales, the shell is marked by conspicuous, interrupted, rather broad spiral bands, which give it a mottled and marbled aspect. The outer peristome is decidedly rayed.

The type, U.S.N.M. no. 492949, is a complete specimen having 6.4 whorls and measures: Length, $24.5 \mathrm{~mm}$; greater diameter, $16.0 \mathrm{~mm}$; lesser diameter, $11.6 \mathrm{~mm}$.

These characters conspicuously differentiate this race from all the others.

\section{CHONDROTHYRETES GUNDLACHI MURALLENSIS, new subspecies}

\section{Plate 22, Figure 2}

This race, from the the Puerta de la Murallia, also has interrupted spiral bands, as in $C$. gundlachi porticola, but they are less pronounced, and the color scheme does not tend toward mottling or marbling, as in the other subspecies. The expanded outer lip is also less conspicuously rayed. 
The type, U.S.N.M. no. 367880 , has 4.8 whorls remaining and measures: Length, $27.0 \mathrm{~mm}$; greater diameter, $16.6 \mathrm{~mm}$; lesser diameter, $12.1 \mathrm{~mm}$.

\section{CHONDROTHYRETES GUNDLACHI DEVIATA, new subspecies}

\section{Plate 22, Figure 4}

In the caves of the mogotes on the south side of the road leading from Luis Lazo to Guane, and separated from the Sierra de Guane by the Rio Portales, Bartsch collected a lot of shells that have finer sculpture than the other races and that may have the spiral threads brown. These vary from white to yellow, unicolor or spirally feebly banded. The peristome is white, at times weakly rayed.

The type, U.S.N.M. no. 387907 , collected as above stated, is a complete specimen, having 6.5 whorls and measuring: Length, $25.6 \mathrm{~mm}$; greater diameter, $16.7 \mathrm{~mm}$; lesser diameter, $12.6 \mathrm{~mm}$.

\section{CHONDROTHYRETES AFFINIS, new species}

Plate 21, Figure 9

1863. Chondropoma gundlachi PfeIfFer, Malakozool. Blätter, vol. 10, p. 182 (in part).

Shell large, thin, ovate-turreted. The early whorls are dark brown, paling gradually anteriorly to buff on the last turn. Peristome white. At more or less regular intervals there are white or light axial zones, and the spiral threads are also light, so that the combination of these two light elements against the dark background lends to the shell a very peculiar fenestrated pattern. Nuclear whorls 2, strongly rounded, smooth. Postnuclear whorls inflated, strongly rounded, and marked by numerous, hairlike, decidedly retractively slanting, axial threads. The spiral sculpture consists of alternating stronger and heavier threads; the lighter threads are about equal to the axial and the heavier are at least twice the size of the lesser. The latter are rendered beautifully beaded by the axial sculpture. Suture strongly constricted. Periphery of the last whorl inflated and strongly rounded. Base inflated and strongly rounded and marked like the spire. Aperture broadly oval. Peristome double, the inner slightly exserted and reflected; the outer more or less broadly expanded, fluted, and marked by fine concentric lines. The outer peristome is cut on the middle of the inner lip posterior to which it is reflected over the umbilicus and parietal wall. The breathing pore is on the parietal wall near the posterior angle of the aperture at a little distance behind the peristome. Operculum with subcentral nucleus. The outside of the last whorl is covered by a rather thick deposit of fine calcareous granules, which are somewhat fluted. 
The type, U.S.N.M. no. 499582, comes from the west end of El Queque. It is a complete specimen, has 7.5 whorls, and measures: Length, $30.7 \mathrm{~mm}$; greater diameter, $18.8 \mathrm{~mm}$; lesser diameter, 13.2 $\mathrm{mm}$.

The species ranges through the Vinales region. It is also found in Dos Hermanos and Puertecitas.

\section{CHONDROTHYRETES PARILIS, new species}

Shell elongate-ovate, varying in color from pure milk white through straw-color, horn-color, orange, and dark brown. It may be unicolor, variegated or marbled, usually the latter. The outer, broadly expanded peristome also varies in color from pale yellow to deeper yellow and is rayed in all specimens but the alabastrian form of $C$. parilis simonis. Nuclear whorls about 2, well rounded, smooth. The postnuclear whorls are moderately rounded and marked by slender retractively curved riblets and spiral threads, the latter considerably stronger than the axial riblets. The junctions of the two form nodules on the early whorls, which become weakened on the later turns. Suture moderately constricted; periphery well rounded. Base short, well rounded. Aperture oval. Peristome double, the outer broadly flaringly expanded and marked by numerous slender concentric lamellae adnate to the preceding turns at the posterior angle and deeply cut in the middle of the inner lip. The part posterior to it reflected over and covering the umbilicus. Parietal wall covered by a broad callus. Operculum typically chondropomoid.

This species ranges through the small mogotes west and south of the Sierra San Andrés as well as the Sierra San Andrés.

\section{KEY TO THE SUBSPECIES OF CHONDROTHYRETES PARILIS}

Spiral threads conspicuously white.

Shell dark brown or red scalaris

Shell not dark brown or red.

Shell horn-color.

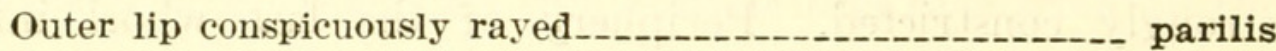

Outer lip not conspicuously rayed. simonis Spiral threads not conspicuously white.

Shell dark brown or reddish fossularis

Shell horn-color amoena

CHONDROTHYRETES PARILIS SCALARIS, new subspecies Plate 23, Figure 1

This race comes from the Escaleras de San Andrés. It is an exceedingly dark race, with rayless orange-colored outer peristome and with the spiral threads white, which gives it a very striking color pattern that readily distinguishes it from all the other races. 
The type, U.S.N.M. no. 468953, has 5.0 whorls and measures: Length, $25.8 \mathrm{~mm}$; greater diameter, $16.2 \mathrm{~mm}$; lesser diameter, 13.0 $\mathrm{mm}$.

CHONDROTHYRETES PARILIS PARILIS, new subspecies

Plate 23, Figure 3

In this race, which comes from Hoyo San Antonio, Mogote de la Jagua, the shell also has conspicuous spiral bands, but the ground color is horn-color, and the outer peristome is conspicuously rayed. There are also inconspicuous interrupted spiral bands of brown.

The type, U.S.N.M. no, 492961, has 5.2 whorls remaining and measures: Length, $24.7 \mathrm{~mm}$; greater diameter, $16.3 \mathrm{~mm}$; lesser diameter, $11.1 \mathrm{~mm}$.

CHONDROTHYRETES PARILIS SIMONIS, new subspecies

Plate 23, Figure 6

This race comes from the Mogote Palmero, which is also called Mogote Simon. Here we have the last whorl also bearing light spiral threads, but the ground color is orange or orange-brown, the nuclear whorls are white, and the outer peristome is without rays or almost so.

The type, U.S.N.M. no. 468951, a complete specimen, has 7.2 whorls and measures: Length, $24.5 \mathrm{~mm}$; greater diameter, $15.6 \mathrm{~mm}$; lesser diameter, $10.4 \mathrm{~mm}$.

Of this species we have two albinos, both alabaster white.

\section{CHONDROTHYRETES PARILIS FOSSULARIS, new subspecies}

Plate 23, Figure 4

This race comes from Hoyo Corto de San Antonio, Asiento de la Jagua. It is a very dark colored race, in which the spiral threads are not light. It varies in coloration from orange to dark brown and has the expanded peristome, which is orange, very conspicuously rayed. The shell may be unicolor, barring the banding at and behind the peristome, or it may be variously banded with interrupted spiral zones of brown.

The type, U.S.N.M. no. 468820, has 4.4 whorls remaining and measures: Length, $22.0 \mathrm{~mm}$; greater diameter, $14.1 \mathrm{~mm}$; lesser diameter, $10.4 \mathrm{~mm}$.

CHONDROTHYRETES PARILIS AMOENA, new subspecies

Plate 23, Figure 7

This race was collected by Arango at Mogote de la Jagua de Azua. It is pale, with a horn-colored ground color and with or without $66879-38-8$ 
slender interrupted spiral bands of brown. The peristome is of the same color as the ground color of the shell except for the numerous very decided rays present on both sides of the expanded portion.

The type, U.S.N.M. no. 367881 , has 5.5 whorls remaining and measures: Length, $24.9 \mathrm{~mm}$; greater diameter, $15.5 \mathrm{~mm}$; lesser diameter, $11.0 \mathrm{~mm}$.

\section{CHONDROTHYRELLA, new genus}

Shell small, varying in shape from ovate to subglobular. The shells may be unicolor or spirally banded. Nuclear whorls about 2, well rounded, smooth except the last part of the last turn, which shows the beginning of the postnuclear sculpture. Postnuclear whorls more or less inflated, strongly rounded, latticed with slender axial riblets and spiral threads, which may form cusps at their intersections. Suture well impressed, simple. Periphery strongly rounded. Base more or less inflated, strongly rounded, marked by the continuations of the axial ribs and spiral threads. Umbilicus open or closed. Aperture broadly oval to subcircular. Peristome double, the inner little exserted, the outer expanded, cut or folded on the inner lip and more or less reflected over the umbilicus; parietal wall covered with a strong callus. A breathing pore is present a little within the edge of the aperture on the parietal wall near the posterior angle. This may open into the exterior at the posterior angle where the whorls are solute or into the umbilicus by means of a canal below the parietal callus; breathing may take place through the umbilicus or when this is closed through the decollated apex. Operculum simple, paucispiral, with more or less of a granular calcareous deposit.

Type: Chondrothyrella (Chondrothyrella) pudica (Orbigny).

This genus of small species is confined to the eastern part of Pinar del Rio Province and the western and central parts of Habana Province.

KEY TO THE SUBGENERA OF GENUS CHONDROTHYRELLA

Umbilicus open Plicathyrella Umbilicus closed Chondrothyrella

\section{Plicathyrella, new subgenus}

Chondrothyrella with the umbilicus open. Breathing pore opening directly to the exterior where the last whorl is solute or through a channel in the parietal callus, connecting with the umbilicus where the last whorl is adnate to the preceding turn. Outer peristome of the inner lip not cut but folded in the middle.

Type: Chondrothyrella (Plicathyrella) assimilis (Gundlach) Pfeiffer. 
KEY TO THE SPECIES OF SUBGENUS PLICATHYRELLA

Surface of shell filelike claudicans Surface of shell not filelike.

Shell chestnut-brown tenebrosa

Shell horn or straw-colored assimilis

\section{ChONDROTHYRELLA (PLICATHYRELlA) ASSIMILIS (Gundlach) Pfeiffer}

Shell varying from small to medium size in the different races, ovate, usually horn-color, sometimes brown, almost always interruptedly spirally banded with brown. Nuclear whorls about 2, inflated, strongly rounded, microscopically granulose; the initial portion of the first turn dark brown, the rest horn-color. Postnuclear whorls very strongly inflated and rounded, crossed by numerous more or less crowded, retractively slanting, axial riblets that vary from threads to slender low lamellae in the different races. The spiral sculpture consists of threads, which are also quite variable in strength in the divers races. The junction of these two elements renders the axial ribs somewhat sinuose and feebly nodulose at their meeting. Suture well constricted. Periphery and base inflated, strongly rounded, the latter openly umbilicated and marked by the continuation of the axial ribs and spiral threads. The last, however, are much stronger about the umbilical region than on the posterior portion of the base. Aperture very broadly oval; peristome double, the outer broadly expanded and reflected, more so on the inner lip than the rest, marked by radial flutings and concentric lamellae. The middle of the outer peristome of the inner lip bears a fold which in some of the races almost amounts to a cut. The part posterior to this is reflected as a flap over the umbilicus, partly covering, or at least shielding it. Operculum thin, red or reddish, corneous with excentric nucleus, covered by a heavy deposit of fine calcareous granules.

Of the animal of $C$. (P.) assimilis assimilis Gundlach says ${ }^{5}$ : "Animal whitish, head with scarcely darker suffusion. Tentacles ochre colored with gray tip." When at rest it suspends itself with a modately long thread.

This species extends through the mountains of a considerable part of eastern Pinar del Rio Province. It has been found from the Sierra la Guira to Pan de Guajaibon east to Mogote de Soroa.

Distribution of the subspecies of $C$. $(P$. $)$ assimilis is shown in figure 98 .

Balakozool. Blätter, vol. 10, p. 186, 1863. 


\section{KEY TO THE SUBSPECIES OF CHONDROTHYRELLA (PLICATHYRELLA) ASSIMILIS}

Early postnuclear whorls distantly ribbed.

Surface of shell exceedingly rough abronensis

Surface of shell not exceedingly rough.

Peristome radially rayed.

Spiral cords in the umbilicus very strong maceoi

Spiral cerds in the umbilicus not very strong signata Peristome not radially rayed.

Spiral threads about the umbilicus rather distantly spaced assimilis

Spiral threads about the umbilicus closely spaced.

Spiral threads about the umbilicus very strong----- cisnerosi Spiral threads about the umbilicus not very strong-- guirensis Early postnuclear whorls closely ribbed. gemma

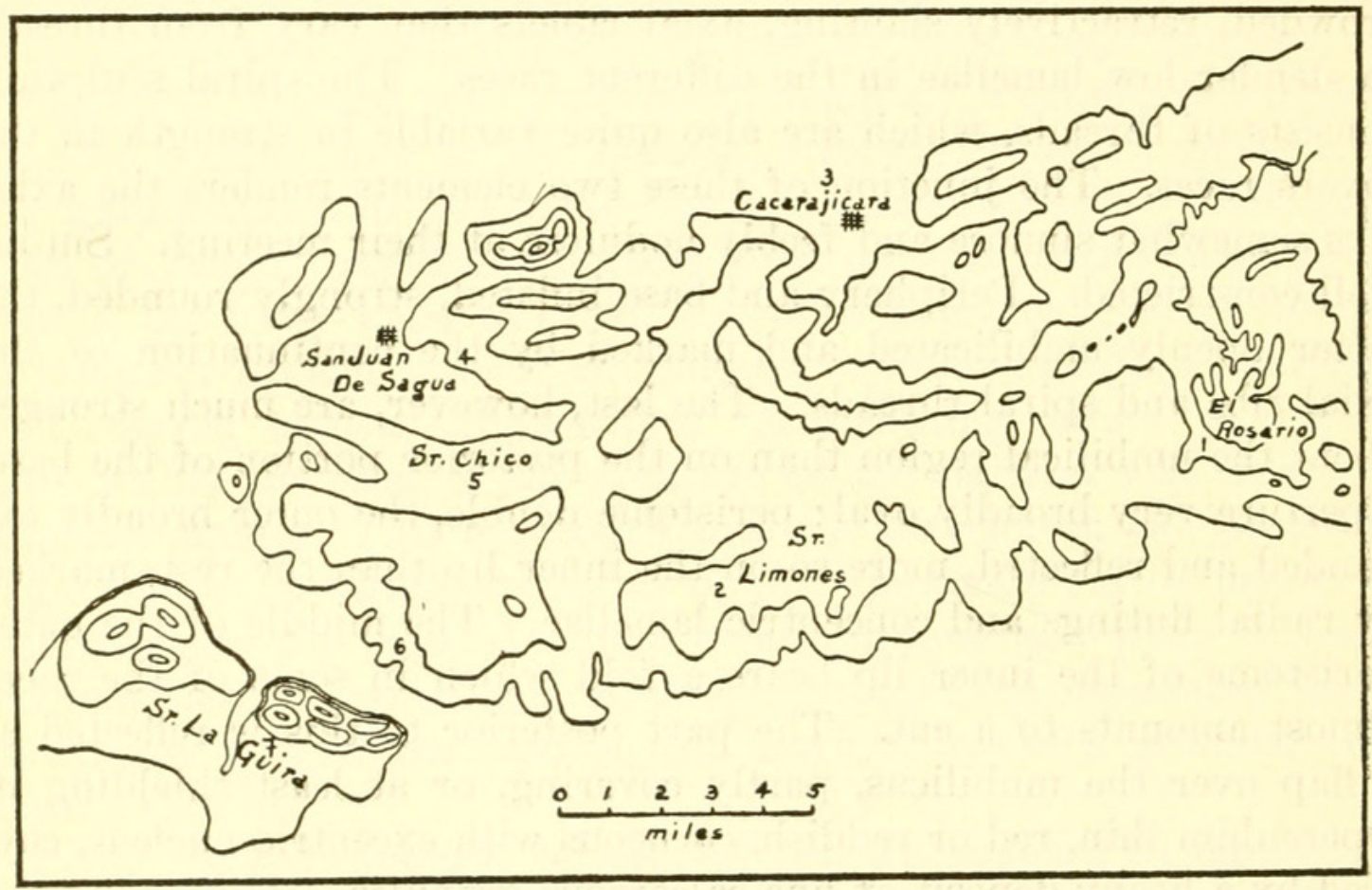

FIgURE 98.-Distribution of the subspecies of Chondrothyrella (Plicathyrella) assimilis: (1) cisnerosi; (2) abronensis; (3) maceoi; (4) assimilis; (5) signata; (6) gemma; (7) guirensis.

\section{CHONDROTHYRELLA (PLICATHYRELLA) ASSIMILIS ABRONENSIS, new subspecies}

Plate 25, Figure 5

This race comes from El Abron, Sierra de Limones. The junctions of the sublamellar axial ribs and spiral threads form very strong cusps, which give to this subspecies a rasplike surface. The peristome is radially rayed with brown and the early postnuclear whorls are distantly ribbed.

The type, U.S.N.M. no. 492732 , a complete specimen, has 6 whorls and measures: Length, $13.0 \mathrm{~mm}$; greater diameter, $10.2 \mathrm{~mm}$; lesser diameter, $6.8 \mathrm{~mm}$. 
CHONDROTHYRELLA (PLICATHYRELLA) ASSIMILIS MACEOI, new subspecies

Plate 25, Figure 2

This race comes from Cacarajicara, 2 miles west of Rancho Lucas. It has the early postnuclear whorls distantly ribbed and the peristome radiatingly rayed with chestnut-brown; there is also a spot of the same color at the notch of the inner lip. The interrupted spiral bands of brown are narrow and faint on the spire but broader and a little more pronounced on the periphery and base. The spiral threads on the anterior half of the base are very strong, which will help to differentiate this easily from $C$. (P.) assimilis signata.

The type, U.S.N.M. no. 468743 , has 4.5 whorls remaining and measures: Length, $15.0 \mathrm{~mm}$; greater diameter, $12.5 \mathrm{~mm}$; lesser diameter, $8.2 \mathrm{~mm}$.

CHONDROTHYRELLA (PLICATHYRELLA) ASSIMILIS SIGNATA, new subspecies

Plate 25, Figure 7

This subspecies comes from the Sierra Chica south of Pan de Guajaibon. It differs from typical $C$. $(P$.) assimitis assimilis in having the peristome radiatingly rayed, and in having a faint dark line at the edge of the summit of the whorls, and from $C$. (P.) assimilis maceoi in having the spiral cords about the umbilicus much less strongly developed. The decidedly inflated whorls are distantly ribbed on the early turns, but here the ribs closely approximate on the last whorl where the spaces that separate them are almost as narrow as the ribs, which are sublamellar and low. The interrupted spiral bands are almost continuous. The peristome of the inner lip is very broad and the flexure not profound.

The type, U.S.N.M. no. 468744 , has a little more than 4 whorls remaining and measures: Length, $15.6 \mathrm{~mm}$; greater diameter, 12.0 $\mathrm{mm}$; lesser diameter, $8.3 \mathrm{~mm}$.

\section{CHONDROTHYRELLA (PLICATHYRELLA) ASSIMILIS ASSIMILIS (Gundlach) Pfeiffer}

Plate 25, Figure 1

1863. Chondropoma assimile (Gundlach Pfetfrer, Malakozool. Blätter, vol. 10, p. 186.

1920. Chondrothyra (Chondrothyretes) assimile Henderson and BARTsch, Proc. U. S. Nat. Mus., vol. 58, p. 64 .

This subspecies comes from San Juan de Sagua, the southwest side of Pan de Guajaibon. It has the early postnuclear whorls rather distantly ribbed; the peristome is pale yellowish, without brown radiating rays. It also has the spiral threads on the anterior half of 
the base fewer and much more distantly placed than those of $C$. $(P$.) assimilis guirensis, which it most nearly resembles.

The type, U.S.N.M. no. 468745, is a complete specimen, having 6.4 whorls and measuring: Length $16.3 \mathrm{~mm}$; greater diameter, 11.8 $\mathrm{mm}$; lesser diameter, $8.2 \mathrm{~mm}$.

\section{CHONDROTHYRELLA (PLICATHYRELLA) ASSIMILIS CISNEROSI, new subspecies}

\section{Plate 25, Figure 6}

This, the largest race of $C$. (P.) assimilis, was collected by Cisneros in the Sierra Rosario. It is dark horn-color, and the broken tip shows the dark columella. It is reticulately latticed but only feebly cusped at the intervals of the axial riblets and spiral threads. Within the umbilicus the spiral threads are very strong and rendered conspicuously cusped by the axial threads.

The type, U.S.N.M. no. 367882 , has 3.9 whorls remaining and measures: Length, $15.3 \mathrm{~mm}$; greater diameter, $12.8 \mathrm{~mm}$; lesser diameter, $9.1 \mathrm{~mm}$.

\section{CHONDROTHYRELLA (PLICATHYRELLA) ASSIMILIS GUIRENSIS, new subspecies}

Plate 25, Figure 4

This race was collected by Arango in the Sierra la Guira northwest of San Diego de los Banos. It has the axial riblets on the early postnuclear whorls very distantly spaced, while those of the last whorl are but slightly elevated and separated by spaces as wide as, or only a little wider than, the ribs. In this subspecies the spiral threads on the anterior part of the base are less strong, more numerous, and closer spaced than in $C$. (P.) assimitis assimilis, with which it shares a faintly yellow peristome.

The type, U.S.N.M. no. 367886, has 4.7 whorls remaining and measures: Length, $14.0 \mathrm{~mm}$; greater diameter, $11.0 \mathrm{~mm}$; lesser diameter, $7.5 \mathrm{~mm}$.

\section{CHONDROTHYRELLA (PLICATHYRELLA) ASSIMILIS GEMMA, new subspecies}

Plate 25, Figure 3

This, the smallest of all the races of this species, comes from Mogote Colorado, one of the limestone blocks on the east side of the Rio San Diego, a short distance north of San Diego de los Banos. Its minute size, combined with the closely spaced axial riblets on the early postnuclear whorls, readily distinguishes it from the other subspecies.

The type, U.S.N.M. no. 468747, has 5.8 whorls remaining and measures: Length, $11.4 \mathrm{~mm}$; greater diameter, $7.7 \mathrm{~mm}$; lesser diameter, $5.9 \mathrm{~mm}$. 


\section{CHONDROTHYRELLA (PLICATHYRELLA) ClAUdiCANS (Poey)}

Shell small, very broadly ovate, when truncated almost subglobular, varying in color from horn-color through orange to brown, unicolor or interruptedly spirally banded. The first portion of the nucleus is blackish brown, the rest much lighter. Peristome pale yellow. Nuclear whorls about 2, inflated, strongly rounded, smooth except for microscopic granules. Postnuclear whorls decidedly inflated, gibbose, strongly rounded, marked by retractively curved, axial riblets, which vary in strength from threads to low lamellae. The spiral sculpture also consists of threads, which vary considerably in strength, numbers, and spacing in the different races and also in the way they render the axial riblets wavy and nodulose at their junction. The axial riblets continue over the inflated periphery and base of the last whorl into the umbilicus undiminished; the spiral threads, however, become stronger and more distantly spaced in most of the races on the anterior half of the base and in the umbilicus. Aperture very broadly ovate; peristome double, the outer broad, flaringly expanded; on the inner lip posterior to the fold almost triple the width of that of the outer lip. The outer peristome is radially fluted and marked with concentric, thin lamellae. The inner peristome is narrow, slightly exserted and reflected. The operculum is thin and reddish, has an excentric nucleus, and is covered by a deposit of minute calcareous granules.

Of the animal $C$. $(P$.$) claudicans claudicans Gundlach is quoted$ by Pfeiffer as saying ${ }^{6}$ : "Animal pale gray with lighter dots; on the edge of the side of the snout a dark spot is present. Tentacles of orange color with a clay yellow suffusion of coral-red with brownish lip." Here he also quotes Poey as saying that the animal with an alternate lateral motion, resting now on the right side of the foot, then on the left. When at rest it suspends itself by a mucous thread.

This species we found hybridizing with Chondrothyrella (Chondrothyrella) perturbata in the gorge of the Rio Taco Taco.

KEY TO THE SUBSPECIES OF CHONDROTHYRELLA (PLICATHYRELLA) CLAUDICANS

Sculpture consisting of rather sharp cusps claudicans

Sculpture consisting of small nodules culminis

\section{CHONDROTHYRELLA (PLICATHYRELla) ClAUdiCANS ClAUdiCANS (Poey)}

\section{Plate 27, Figure 4}

1851. Cyclostoma claudicans Poex, Memorias sobre la historia natural de la Isla de Cuba, pp. 100-106, 444-446, 454, pl. 7, figs. 8-11.

1852. Chondropoma claudicans PFEIFFer, Monographia pneumonopomorum viventium, vol. 1, pp. 295-296 (in part).

1920. Chondrothyra (Chondrothyretes) claudicans Henderson and BARTsCH, Proc. U. S. Nat. Mus., vol. 58, p. 64 .

- Malakozool. Blätter, vol. 3, p. 135, 1856. 
This is the large race that is extremely abundant on the cliffs of the middle ground bordering the path to Rangel. We gathered hundreds of specimens as we made our way to the old Cafetal at the summit. These show varying degrees of umbilication. The sculpture is much stronger than in the other subspecies here recognized, for the junction of the axial ribs and spiral threads produces sharp cusps.

The specimen figured, U.S.N.M. no. 492733, is a complete individual having 6.0 whorls and measuring: Length, $16.7 \mathrm{~mm}$; greater diameter, $13.2 \mathrm{~mm}$; lesser diameter, $9.6 \mathrm{~mm}$.

\section{CHONDROTHYRELLA (PLICATHYRELLA) CLAUDICANS CULMINIS, new subspecies}

Plate 27, Figure 2

On the summit of Rangel we found on isolated limestone blocks, among the coffee plantation, many specimens that were quite uniformly smaller, somewhat paler, and with more closely crowded and weaker axial riblets, which do not form cusps at their junction with the spiral threads but small nodules. To these we are applying the above name.

The type, U.S.N.M. no. 492734 , has 4.5 whorls remaining and measures: Length, $12.3 \mathrm{~mm}$; greater diameter, $9.8 \mathrm{~mm}$; lesser diameter, $7.1 \mathrm{~mm}$.

Similar shells were collected by Hermano Roberto at the Cueva del Rosario, east of and across the river Santa Cruz from Rangel.

CHONDROTHYRELLA (PLICATHYRELLA) TENEBROSA (Morelet)

Shell small, very broadly ovate, chestnut-brown, with faint darker interrupted spiral bands of brown; the peristome may also be chestnut-brown or pale yellow or between these two colors. The nuclear whorls are lost in all our specimens. The postnuclear whorls are very much inflated, rotund, and crossed by slightly sublamellar, retractively curved, axial riblets, which are distantly spaced on the early turns and quite closely approximated on the last whorl, passing undiminished over the inflated periphery and base of the last whorl into the umbilicus. The spiral sculpture consists of slender threads that render the axial riblets somewhat wavy and slightly nodulose at their junction. On the anterior half of the base and in the umbilicus the spiral threads become stronger and more distantly spaced, forming here decided cusps at their junction with the axial riblets. Aperture very broadly ovate, almost circular, peristome double, the outer very broadly expanded, radially fluted and marked with concentric lines of growth, two to three times as wide posterior to the fold on the inner lip as on the rest of the aperture. The plication on the inner lip is usually not strong. Inner peristome slightly exserted and re- 
flected. Operculum red or reddish, with excentric nucleus, covered with a thick deposit of fine calcareous granules on all but the outer edge.

This species, while it resembles $C$. $(P$.$) assimilis, is easily distin-$ guished from that by being almost globular in shape.

Its races all cluster about Pan de Guajaibon.

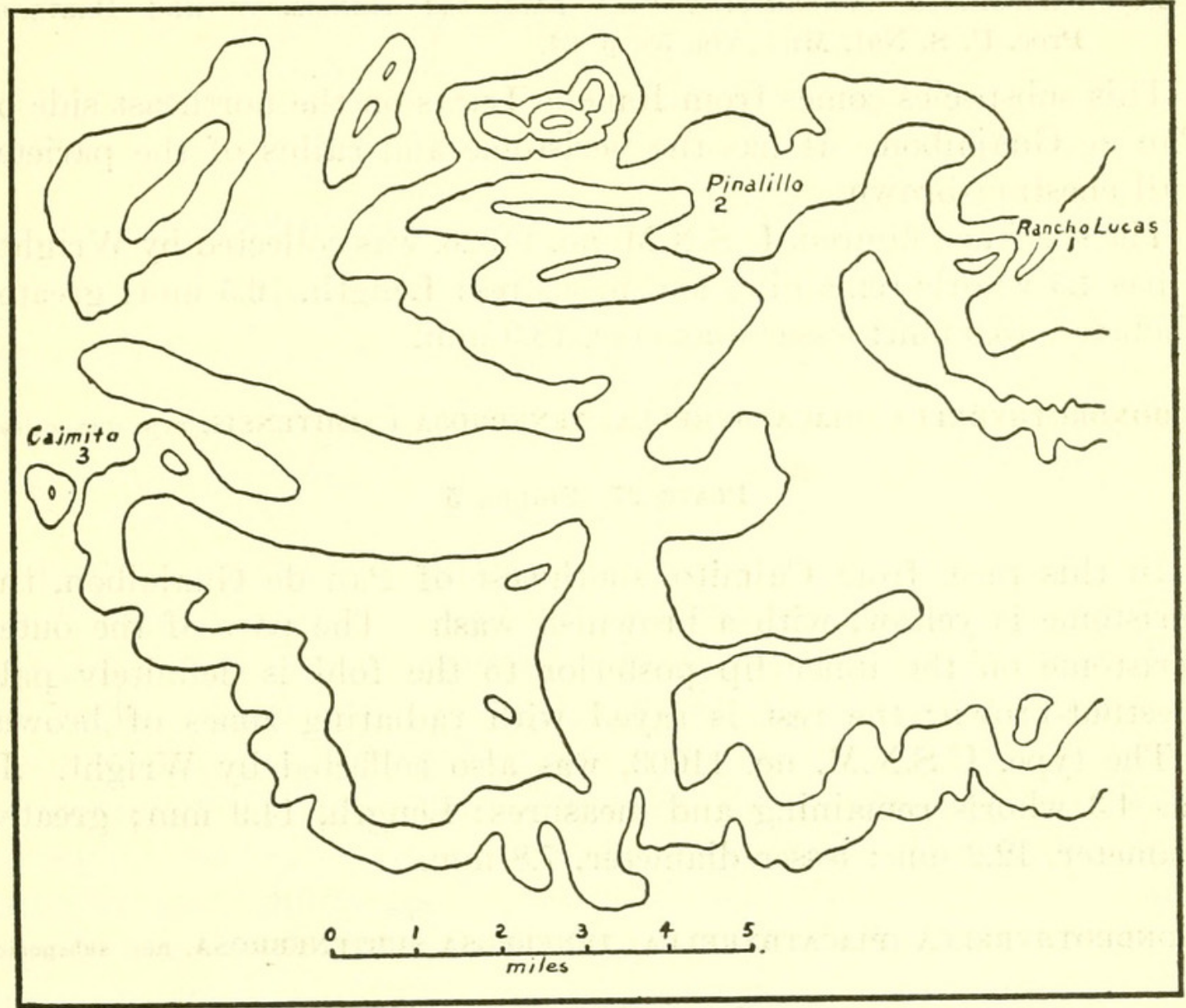

FIgURE 99.-Distribution of the subspecies of Chondrothyrella (Plicathyrella) tenebrosa: (1) tenebrosa; (2) subtenebrosa; (3) caimitensis.

Of the animal of $C$. (P.) tenebrosa tenebrosa, Gundlach says ${ }^{7}$ : "Animal with olive-gray head, neck gray, with Turk blue suffusion, both with white dots which are especially marked about the eyes and base of the tentacles. Foot gray. Tentacles ferruginous with white dots. Eyes black."

Distribution of the subspecies of $C$. $(P$.$) tenebrosa is shown in$ figure 99 .

KEY TO THE SUBSPECIES OF CHONDROTHYRELLA (PLICATHYRELLA) TENEBROSA

Peristome and parietal callus chestnut-brown tenebrosa

Peristome and parietal callus yellow with a brownish wash.

Peristome radially rayed caimitensis

Peristome not radially rayed subtenebrosa

${ }^{7}$ Malakozool. Blătter, vol. 3, p. 135, 1863. 
CHONDROTHYRELLA (PLICATHYRELLA) TENEBROSA TENEBROSA (Morelet)

Plate 27, Figure 3

1849. Cyclostoma tenebrosum MoRELET, Testacea novissima insulae Cubanae et Americae Centralis, pp. 23-24.

1852. Chondropoma tenebrosum PFEIFFer, Monographia pneumonopomorum viventium, vol. 1, pp. 295-296.

1920. Chondrothyra (Chondrothyretes) tenebrosa HeNderson and BARTsch, Proc. U. S. Nat. Mus., vol. 58, p. 64.

This subspecies comes from Rancho Lucas on the northeast side of Pan de Guajaibon. It has the peristome and callus of the parietal wall chestnut-brown.

The specimen figured, U.S.N.M. no. 11026, was collected by Wright; it has 4.5 whorls remaining and measures: Length, $16.5 \mathrm{~mm}$; greater diameter, $13.0 \mathrm{~mm}$; lesser diameter, $18.9 \mathrm{~mm}$.

CHONDROTHYRELLA (PLICATHYRELla) TENEBROSA CAIMITENSIS, new subspecies

Plate 27, Figure 5

In this race, from Caimito, southwest of Pan de Guajaibon, the peristome is yellow, with a brownish wash. The part of the outer peristome on the inner lip posterior to the fold is definitely pale chestnut-brown; the rest is rayed with radiating zones of brown.

The type, U.S.N.M. no. 11003, was also collected by Wright. It has 4.3 whorls remaining and measures: Length, $14.9 \mathrm{~mm}$; greater diameter, $12.2 \mathrm{~mm}$; lesser diameter, $7.8 \mathrm{~mm}$.

CHONDROTHYRELLA (PLICATHYRELLA) TENEBROSA SUBTENEBROSA, new subspecies

Plate 27, Figure 1

This subspecies was collected by Wright at Pinalillo, Sitio del Pinar, north-central part of Pan de Guajaibon. It has the peristome pale yellow, without radiating rays.

The type, U.S.N.M. no. 367885, has 4.5 whorls remaining and measures: Length, $16.1 \mathrm{~mm}$; greater diameter, $12.8 \mathrm{~mm}$; lesser diameter, $8.2 \mathrm{~mm}$.

\section{CHONDROTHYRELLA, new subgenus}

Chondrothyrella with the umbilicus closed by the reflected inner lip of the outer peristome. The breathing pore connects with the umbilicus by a slender space in the parietal callus; the breathing is accomplished through the hollow axis and the decollated apex.

Type: Chondrothyrella (Chondrothyrella) pudica (Orbigny). 
KEY TO THE SPECIES OF SUBGENUS CHONDROTHYRELLA

Axial sculpture very fine and closely spaced pudica

Axial sculpture only moderately fine and not closely spaced.

Umbilicus open or closed; tip cinnabar red.

perturbata

Umbilicus closed; tip not cinnabar red.

Shell straw-color excisa

Shell not straw-color.

Shell brown.

Columella with a red spot ottonis Columella without a red spot.

Shell broadly ovate cuzcoensis

Shell ovate petricosa

\section{CHONDROTHYRELLA (CHONDROTHYRELLA) PUDICA (Orbigny)}

Plate 24, Figures 3,4

1842. Cyclostoma pudicum ORBIGNY, in Sagra's Histoire physique, politique et naturelle de l'Ile de Cuba, vol. 1, pp. 259-260, pl. 22, fig. 6, 7, 8", not 8 or $8^{\prime}$.

1851. Cyclostoma sericatum Morelet, Testacea novissima insulae Cubanae et Americae Centralis, pt. 2, p. 20.

Shell broadly ovate, almost turbinate, varying in general tone of color from brown to plum color. Nuclear whorls flesh-color, with a dark point at the tip, gradually turning darker toward the end of the nuclear spire. The peristome is yellowish white. Nuclear whorls 2.2 , smooth except the last portion of the last turn, which shows the beginning of the postnuclear sculpture. Postnuclear whorls inflated, strongly rounded, marked by retractively slanting, slender, sublamellar axial riblets, which are more distantly spaced on the early whorls than on the last, where they are rather crowded. The spiral sculpture consists of threads, which are a little stronger than the axial riblets. The intersections of the axial riblets and the spiral threads form weak elongated nodules having their long axis parallel with the axial sculpture. Suture strongly constricted. Periphery of the last whorl inflated, strongly rounded. Base short, inflated, strongly rounded with a rather well-impressed umbilical region, which is marked by the continuations of the axial riblets and spiral cords. The latter are a trifle stronger on the base than on the posterior portion of the whorl. Aperture large, very broadly oval; peristome double, the outer broadly expanded, not quite all in one plane, marked by concentric lines of growth and radiating corrugations; the outer peristome is deeply notched a little anterior to the middle on the inner lip; the portion posterior to this notch is reflected over the umbilical area as a broad callus completely covering the umbilicus; on the parietal wall the outer peristome is reflected over the preceding turn and adnate to it; the inner scarcely at all 
elevated above the outer, slightly reflected and appressed to it. The breathing pore is at some little distance behind the peristome on the parietal wall and close to the posterior angle of the aperture. The operculum is thin, paucispiral, with submarginal nucleus, the outside covered with a thin deposit of fine calcareous granules.

This species was found abundantly on the limestone cliffs and talus slopes on the north side of Mount Guajaibon, near the western end of the mountain, Pinar del Rio, Cuba.

The specimen described and figured is a complete individual, having 6.0 whorls, and measuring: Length, $14.2 \mathrm{~mm}$; greater diameter, $10.2 \mathrm{~mm}$; lesser diameter, $7.5 \mathrm{~mm}$.

The chubby shape, fine sculpture, and dark color pattern with the brilliantly contrasted peristome give this race a very distinct aspect.

This species was described by Orbigny in 1842 in Sagra's Histoire de l'Île de Cuba, vol. 1, pp. 259-260, and figured on plate 22, figures 6,7 , and $8^{\prime \prime}$, but not 8 or $8^{\prime}$. Figures 8 and $8^{\prime}$ represent an operculum belonging to Rhytidothyra bilabiata Orbigny, the shell of which is figured on the same plate as 3,4 , and 5 , but without operculum. The case simply represents a transposition of the operculum from the one species to the other. Morelet, failing to recognize this transposition, renamed the shell Cyclostoma sericatum.

\section{CHONDROTHYRELla (CHONDROTHYRELLA) PERTURBATA, new species}

Plate 24, Figure 2

Shell very broadly ovate, the nuclear tip with an orange initial portion followed by horn-colored turns. The postnuclear whorls are bright orange, which usually becomes diluted on the last or sometimes the last two turns. Peristome pale yellow. Nuclear whorls a little more than 2 , strongly rounded, smooth; the postnuclear whorls are inflated, strongly rounded, and marked by slender, retractively slanting, axial riblets and stronger spiral threads. The intersection of the two forms elongated nodules whose long axis corresponds with the axial sculpture. The spaces enclosed between the axial riblets and the spiral threads are rectangular pits, having their long axis also in agreement with the axial sculpture. Suture strongly impressed; periphery inflated, strongly rounded. Base inflated, strongly rounded, and marked like the spire. Aperture very broadly oval; peristome double; the inner slightly exserted and appressed to the outer, which is broadly flaringly expanded, somewhat fluted and marked by slender concentric lamina. The outer peristome is cut in the middle of the inner lip and the posterior portion is reflected over the umbilicus as a broad flap, completely closing this. The parietal wall is covered with a heavy callus. Operculum thin, paucispiral, corneous, with a heavy deposit of calcareous granules. 
The type, U.S.N.M. no. 422735, was collected by Henderson and Bartsch in the gorge of the Taco Taco River about a mile from its entrance. It has 4.4 whorls remaining and measures: Length, 13.5 $\mathrm{mm}$; greater diameter, $10.8 \mathrm{~mm}$; lesser diameter, $7.0 \mathrm{~mm}$.

This species is a very perturbing element, for we are here undoubtedly dealing with a hybrid problem in which one extreme is exemplified by the above description, and since a large number of individuals in our series represent this type, we are bestowing upon it the name perturbata. There are intergrades between this and the openly umbilicated $C$. (Plicathyrella) claudicans (Poey), and the range of color variation extends from the picture portrayed in our description to that of the dark form of typical $C$. (P.) claudicans. It is doubly interesting since two of the subgenera, namely, Chondrothyrella and Plicathyrella, find representations in the hybrid complex.

\section{CHONDROTHYRELLA (CHONDROTHYRELLA) EXCISA (Gundlach) Pfeiffer}

\section{Plate 24, Figure 1}

1863. Chondropoma excisum (GundLACH) Pfeiffer, Malakozool. Blätter, vol. 10, pp. 187-188.

Shell very broadly ovate, pale yellow, with interrupted spiral bands of brown. The elements composing these bands are arranged in both axial and spiral series. Nuclear whorls decollated in all our specimens, a portion of the last volution only remaining, which is smooth except that at its termination it shows the beginning of the axial sculpture of the postnuclear turns. Postnuclear whorls strongly rounded, appressed at the summit, marked by slender, almost sublamellose, closely spaced, retractively slanting axial riblets, which are a little more distantly spaced on the early turns than the later. These riblets on the last whorl are separated by spaces about the width of the riblets. The spiral sculpture is very feeble on the first of the postnuclear whorls and slowly increases in strength with the succeeding turns. The spiral threads are considerably stronger than the axial lamellae and render these wavy. Of these spiral threads, 8 are present on the second, 18 upon the third, and the last between the summit and the suture. On the last turn the intersection of the spiral threads with the axial riblets produces alongated oval tubercles, which have their long axis parallel with the axial sculpture. Periphery inflated, strongly rounded. Base short, inflated, broadly umbilicated, well rounded, and marked by the continuations of the axial riblets and 20 spiral threads, equaling those of the anterior portion of the last whorl in strength and spacing. Within the umbilicus the spiral sculpture appears to be absent, at least as far as can be seen through the slit when it is open. Aperture very broadly oval; peristome double, the outer broadly expanded, almost flattened, 
marked by concentric lines of growth and almost obsolete corrugations; the outer peristome is cut a little anterior to the middle of the inner lip, and posterior to this it is very broadly expanded to at least treble the width of the rest of the outer peristome, the expanded portion extending over the umbilicus as a fold, which it frequently completely covers though at times only partly so; the outer peristome of the parietal wall is a little narrower than on the rest of the shell and is appressed to and adnate with the preceding turn; the outer peristome shows the color bands as reddish-brown rays; inner peristome somewhat expanded and slightly reflected. The breathing pore is at some little distance behind the peristone on the parietal wall and close to the posterior angle of the aperture. The operculum is thin, paucispiral, with submarginal nucleus, the outside covered with a thin deposit of fine calcareous granules.

The specimen described and figured, U.S.N.M. no. 492992, conies from the north side of Guajaibon without specific designation as to what particular portion of the north part. It has a little more than 4 whorls and measures: Length, $12.3 \mathrm{~mm}$; greater diameter, $12.0 \mathrm{~mm}$; lesser diameter, $7.3 \mathrm{~mm}$.

We have also seen this species from Cacarajicara, a little north of Guajaibon.

Of this species Gundlach ${ }^{8}$ says: "On paradones on the northern slope of Guajaibon. Animal whitish with still whiter dots on the rugosities and especially about the eyes. Head with reddish suffusion. Antennae coral-red with white tip. When at rest, suspended by a moderately long mucous thread."

\section{CHONDROTHYRELLA (CHONDROTHYRELLA) OTTONIS (Pfeiffer)}

Shell moderately large, ovate, ranging from flesh-color to purplish brown, unicolor or banded with interrupted spiral bands of brown; peristome white or yellowish. Nuclear whorls 2, well rounded, smooth. Postnuclear whorls inflated, strongly rounded, marked by retractively slanting axial riblets, of which the early ones are usually a little more distantly spaced than the later. The spiral sculpture consists of numerous, very slender threads, like the axial riblets also varying in number and spacing in the different races, Suture well constricted. Periphery well rounded. Base inflated, strongly rounded, and marked by the continuation of the axial riblets and spiral threads, the latter usually a little stronger about the umbilicus than on the rest of the base. Aperture broadly oval; peristome double, the outer flaringly expanded, marked by concentric laminae, deeply notched on the middle of the inner lip, posterior to which it is reflected over the umbilicus which it com-

${ }^{8}$ Malakozool. Blätter, vol. 10, p. 188, 1863. 
pletely covers, and frequently also the area adjacent to the umbilicus; on the parietal wall it extends over the preceding turn to which it is adnate. Inner peristome exserted, slightly reflected. Breathing pore on the parietal wall near the posterior angle of the aperture a little behind the peristome. Operculum with the nucleus halfway between marginal and central, the outside covered with a rather thick deposit of calcareous granules.

This species ranges through the mountains north of Candelaria to Cuzco.

The animal of $C$. $(C$.) ottonis ottonis has the body flesh-color, with smoky suffusion; the eye stalks are coral-red.

KEY TO THE SUBSPECIES OF CHONDROTHYRELLA (CHONDROTHYRELLA) OTTONIS

Peristome with radiating lines of brown ottonis

Peristome without radiating lines of brown riohondensis

\section{CHONDROTHYRELLA (CHONDROTHYRELLA) OTTONIS OTTONIS (Pfeiffer)}

\section{Plate 26, Figure 5}

1846. Cyclostoma ottonis PFeIfFer, Zeitschr. Malak., vol. 3, p. 45.

This subspecies is very abundant along the stone fences and limestone exposures about Taburete, La Tumba, and Soton. It is elongate-ovate, dark in color with feeble brown radiations on the outer peristome.

It differs from $C .(C$.) ottonis riohondensis in having the whorls much less inflated and possessing the radiation of the outer peristome.

The figured specimen, U.S.N.M. no. 499591, was collected by Bartsch at Taburete. It has 4.7 whorls remaining and measures: Length, $18.0 \mathrm{~mm}$; greater diameter, $12.0 \mathrm{~mm}$; lesser diameter, $8.5 \mathrm{~mm}$.

\section{CHONDROTHYRELLA (CHONDROTHYRELLA) OTTONIS RIOHONDENSIS, new subspecies}

\section{Plate 26, Figure 4}

This race extends through the mountains from Rio Hondo northward through Pena Blanca and El Mulo. It varies somewhat in color but is usually paler than the typical race, with the whorls much more inflated and the peristome white without radiation.

The type, U.S.N.M. no. 493004, comes from Rio Hondo. It has 4.9 whorls remaining and measures: Length, $18.3 \mathrm{~mm}$; greater diameter, $12.9 \mathrm{~mm}$; lesser diameter, $9.3 \mathrm{~mm}$.

\section{CHONDROTHYRELLA (CHONDROTHYRELLA) CUZCOENSIS, new species}

Shell varying in shape from ovate to broadly ovate and in color from flesh-color to brown, unicolor or interruptedly spirally lined with brown; peristome white or faintly rayed with brown. Nuclear 
whorls about 2, small, strongly rounded, smooth, with a dark spot at the beginning. Postnuclear whorls inflated, strongly rounded, and marked with very slender sublamellar axial ribs, which are closely crowded but only about one-half or less as wide as the spaces that separate them. The spiral sculpture consists of slender threads, which are less strong than the axial riblets and which render these somewhat wavy, scarcely denticulate. Suture strongly constricted. Periphery inflated, strongly rounded. Base short, inflated, strongly rounded, and marked like the spire. Aperture broadly oval; peristome double, the inner little exserted, reflected upon and adnate to the outer which is broadly expanded, somewhat fluted and marked with feeble concentric lamellae, cut in the middle of the inner lip, with the posterior portion of this covering the umbilicus; parietal wall covered with a heavy callus. Breathing pore on the parietal wall near the posterior angle at some distance from the edge, communicating with the umbilicus and the exterior through the hollow axis and the decollated apex. Operculum paucispiral, covered with a moderately strong calcareous deposit.

This species ranges through the mountains a little east and west and north of Candelaria.

We recognize two subspecies, which the following key will help to distinguish:

KEY TO THE SUBSPECIES OF CHONDROTHYRELLA (CHONDROTHYRELLA) CUZCOENSIS

Whorls decidely inflated caroli Whorls not decidedly inflated. cuzcoensis

\section{CHONDROTHYRELLA (CHONDROTHYRELLA) CUZCOENSIS CAROLI, new subspecies}

\section{Plate 24, Figure 5}

This race, which is rather thin-shelled, usually pale horn-color, and interruptedly spirally lined, is decidedly inflated and has very many very slender axial riblets. It comes from the region of Soroa.

The type, U.S.N.M. no. 367888, was collected by Carlos de la Torre, Jr., at the Finca Sostenido. It has 3.8 whorls and measures: Length, $15.0 \mathrm{~mm}$; greater diameter, $10.8 \mathrm{~mm}$; lesser diameter, $8.3 \mathrm{~mm}$.

Its decidedly inflated whorls easily distinguish it from $C .(C$.) cuzcoensis cuzcoensis.

CHONDROTHYRELLA (CHONDROTHYRELLA) CUZCOENSIS CUZCOENSIS, new subspecies

Plate 24, Figure 6

In this subspecies the shell is much less inflated and the axial riblets a little less slender and less closely spaced than in $C .(C$. $)$ cuzcoensis caroli. Its distribution is more extensive. We have collected 
it in the mountains north of Candelaria, at Frias, La Tumba, Finca Dolores, and El Mogote.

The type, U.S.N.M. no. 499592, comes from Loma Pimienta, 7 miles north of Candelaria. It has 4.4 whorls remaining and measures: Length, $14.9 \mathrm{~mm}$; greater diameter, $9.5 \mathrm{~mm}$; lesser diameter, $7.0 \mathrm{~mm}$.

\section{CHONDROTHYRELLA (CHONDROTHYRELLA) PETRICOSA (Morelet)}

Shell elongate-ovate, thin, varying in color from flesh-color to pale yellow, through pale brown to purplish brown, unicolor or spirally banded; the peristome is yellowish or brownish and rayed. Nuclear whorls 2, well rounded, smooth except the last portion of the last turn, which shows the beginning of the postnuclear sculpture. Postnuclear whorls well rounded, slightly shouldered at the summit, marked by retractively slanting, sublamellar axial riblets, which are rather closely spaced. These riblets are rendered wavy by spiral threads, which slightly thicken them at their junction with the axial riblets. Suture strongly constricted. Periphery well rounded. Base moderately long, well rounded, marked by the continuation of the axial riblets and spiral threads, the latter becoming a little stronger toward the umbilicus. Aperture very broadly oval; peristome double, the outer flaringly expanded, deeply notched on the middle of the inner lip and reflected over the umbilicus and part of the base posterior to the notch, extending broadly upon the preceding whorl on the parietal wall, marked by concentric laminae and slightly fluted; inner peristome slightly exserted and slightly reflected. Breathing pore on the parietal wall near the posterior angle of the aperture and at some little distance behind the peristome. Operculum with the nucleus half way between marginal and central, marked on the outside by a rather thick deposit of calcareous granules.

This race is found over the eastern end of Pinar del Rio, Cuba, and the western end of Habana Province. It breaks up into several subspecies.

Of $C$. $(C$.) petricosa petricosa collected on stone fences near Vente, Almendares, Habana Province, July 12, 1928, we have the following color note:

Animal flesh-colored, with smoky suffusion and many fine white elongated spots; tentacles dull brownish orange, whitish at base; foot short, bifid; motion of two sides alternate.

KEY TO THE SUBSPECIES OF CHONDROTHYRELLA (CHONDROTHYRELLA) PETRICOSA

Sculpture feeble petricosa

Sculpture not feeble.

Shell dark brown

elisabethae

Shell horn color anafensis

$66879-38-9$ 
CHONDROTHYRELLA (CHONDROTHYRELLA) PETRICOSA PETRICOSA (Morelet)

Plate 26, Figure 2

1851. Cyclostoma petricosum Morelet, Testacea novissima insulae Cubanae et Americae Centralis, pt. 2, pp. 19-20.

This subspecies, which was described by Morelet from Almendares, is characterized by its enfeebled sculpture, which gives it a worn aspect. The color of it varies throughout the range of the species, and it is also quite variable in size. It ranges westward to the Sierra Anafe and Guanjay.

The specimen figured, U.S.N.M. no. 492995, is a topotype from Almendares. It has 4.5 whorls remaining and measures: Length, $14.5 \mathrm{~mm}$; greater diameter, $9.8 \mathrm{~mm}$; lesser diameter, $6.9 \mathrm{~mm}$.

\section{CHONDROTHYRELLA (CHONDROTHYRELLA) PETRICOSA ELISABETHAE, new subspecies}

\section{Plate 26, Figure 3}

This subspecies possesses a much stronger and rougher sculpture than the typical form and is almost black in coloration, with strong radiating rays on the outer peristome.

The type, U.S.N.M. no. 499596, was collected by Dr. Aguayo on the Ariguanabo River. It has 4.3 whorls remaining and measures: Length, $12.8 \mathrm{~mm}$; greater diameter, $9.0 \mathrm{~mm}$; lesser diameter, 6.8 $\mathrm{mm}$.

We have also seen this race from San Antonio and Santiago de las Vegas and the region about Chorrera.

CHONDROTHYRELLA (CHONDROTHYRELLA) PETRICOSA ANAFENSIS, new subspecies

Plate 26, Figure 1

On the summit of the Anafe hills we find a form that, while belonging to this species, differs materially from typical $C$. $(C$.) petricosa, which is found at the base of the hills, in having the sculpture ever so much stronger and in this respect resembling $C$. $(C$.) petricosa elisabethae.

The type, U.S.N.M. no. 493001, comes from the summit of Sierra Anafe and has 4.5 whorls remaining. It measures: Length, 15.0 $\mathrm{mm}$; greater diameter, $9.4 \mathrm{~mm}$; lesser diameter, $6.5 \mathrm{~mm}$.

\section{Genus CHONDROPOMA Pfeiffer}

1847. Chondropoma Pfeiffer, Zeitschr. Malak., vol. 6, p. 109.

Shell ranging in form from turbinate to elongate-conic; the sculpture in varying intensity may consist of axial ribs only or of axial 
ribs and finer axial threads or of axial ribs and spiral threads. All, even those without spiral sculpture on spire and base, have spiral threads on the umbilical wall. No special breathing device is developed in the members of this genus. The operculum is simple; that is, it consists of a chondroid plate made up of a varying number of whorls, the outer thin edges of which are sometimes faintly upturned to form a suggestion of an obsolete lamella. The outer surface of the operculum has a deposit of calcareous granules, which is usually very slight but in some species rather pronounced. In no instance is this entirely absent. The position of the opercular nucleus, whether excentric or subcentral, depends upon the shape of the aperture.

Type: Cyclostoma sagra Orbigny. Selected by Petit in 1850.

\section{KEY TO THE SUBGENERA OF GENUS CHONDROPOMA}

Junctions of axial ribs and spiral threads forming sharp cusps.

Outer peristome broadly expanded

Chondropomartes

Outer peristome not broadly expanded Chondropomisca

Junctions of the axial ribs and spiral threads not forming sharp cusps.

Shell very broadly ovate Gutierrezium

Shell not very broadly ovate.

Axial ribs gathered into tufts at the summit of the whorls.

Axial ribs threadlike; sculpture reticulated_---- Chondropomorus

Axial ribs sublamellar; sculpture vertebrated_.- Chondropomodes Axial ribs not gathered into tufts at the summit of the whorls

Chondropoma

\section{Subgenus Chondropoma Pfeiffer}

1847. Chondropoma Pfeiffer, Zeitschr. Malak., vol. 6, p. 109.

Shell ranging in form from ovate-conic to elongate-conic. The axial sculpture consists of ribs or riblets, which vary considerably in strength in the different species. The riblets are never gathered into tufts at the summit. The spiral sculpture is also quite variable, but regardless of its strength it is found upon all parts of the spire and base. The peristome may be simple or expanded. No breathing device is present. Operculum typically chondropomoid.

Type: Cyclostoma sagra Orbigny=Chondropoma (Chondropoma) pictum sagra Orbigny.

\section{KEY TO THE SPECIES OF SUBGENUS CHONDROPOMA}

Axial sculpture stronger than spiral.

Shell elongate-conic marginalbum

Shell ovate.

Suture strongly denticulate carenasense

Suture not strongly denticulate obesum 
Axial sculpture not stronger than spiral.

Axial and spiral sculpture of equal strength.

Axial ribs strong and distantly spaced.-_-_-_-_-_._-_- oxytremum

Axial ribs fine and closely spaced edouardi

Axial and spiral sculpture not of equal strength.

Spiral sculpture stronger than axial.

Summit of the whorls strongly denticulate.

Spiral sculpture sublamellar.

Shell moderately slender. cabrerai

Shell rather stout. perlatum

Spiral sculpture not sublamellar.

Spiral sculpture consisting of slender threads.

Peristome simple.

Shell elongate-conic vespertinum

Shell ovate jaulense

Peristome double.

Peristome strongly auriculate at posterior angle. Postnuclear whorls strongly rounded_ nicolasi Postnuclear whorls not strongly rounded.

appendiculatum

Peristome not strongly auriculate at posterior angle.

Outer peristome of inner lip very broad. pfeifferianum

Outer peristome of inner lip not very broad.

Denticulations at summit distant.

poeyanum

Denticulations at summit very close.

laetum

Summit of the whorls minutely denticulate.

Shell strongly inflated, rotund.

Peristome simple moestum

Peristome double.

Suture channeled garcianum

Suture not channeled.

Outer peristome rather broadly expanded.

antonense

Outer peristome not broadly expanded_- yucayum Shell not strongly inflated, not rotund.

Shell elongate-ovate.

Suture channeled wilcoxi

Suture not channeled.

Peristome simple cognatum

Peristome double.

Outer peristome auriculate at posterior angles leoni

Outer peristome not auriculate at posterior angles.

Whorls strongly rounded pictum

Whorls almost flattened lembeyi 


\section{CHONDROPOMA (CHONDROPOMA) POEYANUM (Orbigny)}

Complete shell elongate-conic; truncated shell very elongate-ovate. Ground color ranging from flesh-color through straw-color to pale brown; the whorls are marked by interrupted spiral bands of brown. Nuclear whorls almost 2, forming a somewhat truncated apex; smooth except the last portion of the last turn, which shows indication of both axial and spiral sculpture. The postnuclear whorls are strongly rounded and narrowly shouldered, the shoulder being marked by denticles of somewhat varying strength. The axial sculpture consists of obsolete threads and incremental lines, while the spiral sculpture consists of rather strong, distantly spaced threads. Suture narrowly channeled. Perphery well rounded. Base short, well rounded, narrowly openly umbilicated, marked by the continuation of the lines of growth and spiral cords. There are also spiral cords present on the umbilical wall. Aperture broadly oval; peristome single or double, when double the outer and inner one fused on the outer lip but very distinct on the inner and basal lip. Operculum thin, paucispiral with the nucleus half way between submarginal and subcentral.

Of the animal Gundlach ${ }^{9}$ says: "Animal pale, head and tentacles with clay-yellow coloration. Black dots are present on the side flaps of the snout and upon the head and neck. The upper side of the tentacles is blackish and their tip clay-yellow and shining. Eyes small and very dark."

This is a coastwise species that ranges from Santa Cruz del Norte westward to the Cabanas Light.

KEY TO THE SUBSPECIES OF CHONDROPOMA (CHONDROPOMA) POEYANUM

Whorls inflated.

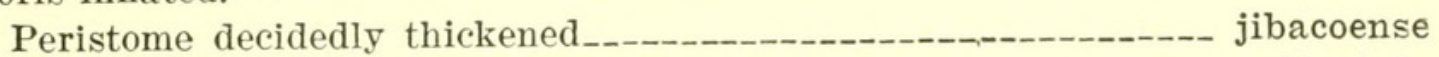

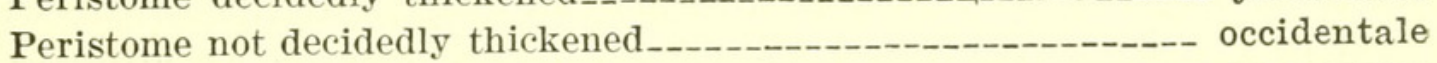

Whorls not inflated.-_- poeyanum

CHONDROPOMA (CHONDROPOMA) POEYANUM JIBACOENSE, new subspecies

Plate 30, Figure 5

This is the easternmost representative of this species. It comes from Santa Cruz del Norte, Habana Province. Here we have a comparatively thin shell of pale horn-color, interruptedly spirally banded or maculated with rather broad, poorly developed, and more or less closely spaced denticulations at the summit. The axial sculpture is emphasized more than in the typical race, while the spiral is less developed, and this gives to the posterior portion of the whorl

๑ Malakozool. Blätter, vol. 3, p. 131, 1856. 
a somewhat feeble obsoletely reticulated aspect. The peristome is thickened and the inner lip conspicuously double.

The type, U.S.N.M. no. 493008, has 3.3 whorls remaining and measures: Length, $12.2 \mathrm{~mm}$; greater diameter, $7.4 \mathrm{~mm}$; lesser diameter, $6.5 \mathrm{~mm}$.

\section{CHONDROPOMA (CHONDROPOMA) POEYANUM POEYANUM (Orbigny)}

Plate 30, Figure 6

1942. Cyclostoma poeyanum ORBIGNy, in Sagra's Histoire physique, politique et naturelle de l'Ile de Cuba, vol. 1, p. 264, pl. 22, figs. 24-27.

1851. Chondropoma poeyanum PFeIfFer, Zeitschr. Malak., 1851, p. 172 (in part). 1856. Chondropoma tenuiliratum PFEIfFer, Malakozool. Blätter, vol. 3, pp. 48-49.

This subspecies comes from the immediate vicinity of Habana, being particularly abundant about the coastal ridge between Cabanas and Cojimar.

The typical form is more inclined to a cylindro-conic shape than the two other subspecies, which have more inflated whorls. Here we find the range of variation from the simple to the double lip in every gathering, which makes it necessary to fuse tenuilirata with this subspecies.

The specimen described and figured, U.S.N.M. no. 104483, has 4.5 whorls remaining and measures: Length, $12.6 \mathrm{~mm}$; greater diameter, $7.2 \mathrm{~mm}$; lesser diameter, $6.0 \mathrm{~mm}$.

\section{CHONDROPOMA (CHONDROPOMA) POEYANUM OCCIDENTALE, new subspecies}

Plate 30, Figure 7

This race occupies the west range of the species. We have it from Cabanas Light. The shell is thin and shining, and the spiral sculpture is enfeebled, giving the axial sculpture greater prominence by contrast. The whorls are inflated, in this respect resembling $C$. $(C$.) poeyanum jibacoense, but here the shell is much thinner and the peristome much less thickened and less conspicuously double on the inner lip.

The type, U.S.N.M. no. 367791, comes from Cabanas Light. It has 3.3 whorls remaining and measures: Length, $13.3 \mathrm{~mm}$; greater diameter, $7.8 \mathrm{~mm}$; lesser diameter, $6.3 \mathrm{~mm}$.

\section{CHONDROPOMA (CHONDROPOMA) LEMBEYI, new species}

Plate 30, Figure 8

The truncated shell is elongate-ovate. The first of the remaining whorls is pale brown, the rest flesh-color, marked by interrupted spiral lines of brown; the elements making up these bands are arranged in both axial and spiral series and not infrequently become 
confluent in both directions; the partial wall is purplish brown. The postnuclear whorls are well rounded, narrowly shouldered at the summit, which is finely denticulated, the denticles varying in strength and spacing in different individuals. The axial sculpture consists of slender, retractively slanting threads, while the spiral consists of rather strong spiral cords, of which 7 are present on the first of the remaining turns, 12 on the second, and 13 on the last whorl. Suture well constricted, narrowly channeled. Periphery of the last whorl somewhat inflated, strongly rounded. Base strongly rounded, marked by the continuation of the axial lines of growth and spiral cords, which are as strong as those on the spire. Within the umbilicus, however, the spiral cords become slightly weakened. Umbilicus narrow, open. Aperture rather large, decidedly oblique. Peristome double; the inner slightly exserted; the outer widely expanded all around and a little more so on the columella than the rest, usually adnate to the preceding turn, although in some shells it is free from it, which gives to the last whorl the impression of being slightly solute. Operculum thin, paucispiral, with the nucleus halfway between the submarginal and subcentral, covered on the outside with a thin deposit of calcareous granules.

The type, U.S.N.M. no. 367791, comes from San Antonio de los Banos. It has 4.5 whorls remaining and measures: Length, $14.6 \mathrm{~mm}$; greater diameter, $17.8 \mathrm{~mm}$; lesser diameter, $6.4 \mathrm{~mm}$.

This species has probably been confused in the past with $C .(C$.) tenuilirata Pfeiffer, which we have now been forced to make a synonym of $C$. $(C$.) poeyanum. It occupies a range south of pfeifferianum in Habana Province and is easily distinguished from this by its stronger sculpture and by the fact that the peristome is expanded all around.

\section{CHONDROPOMA (CHONDROPOMA) LEONI, new species}

Plate 30, Figure 10

The truncated shell is very elongate-ovate. Nuclear whorls decollated in all our specimens. The remaining whorls flesh-color with interrupted spiral bands of brown, of which the one at the periphery is a little more conspicuous than the rest. This is usually also the case in the one on the middle of the base, which almost equals it in strength. The whorls remaining are well rounded, narrowly obliquely shouldered at the summit, and marked by weak, retractively slanting, axial threads. The spiral sculpture consists of conspicuous spiral threads, of which 10 are present between summit and suture on the first of the remaining whorls and 17 on the rest. The junctions of the axial ribs and spiral threads form very weak indications of nodules, while the spaces enclosed between them form shallow rectangular 
pits. Suture not channeled. Periphery of the last whorl strongly rounded. Base narrowly, openly umbilicated, slightly inflated, well rounded, and marked by the continuation of the axial riblets, which here become intensified, and spiral threads equaling those on the spire in strength; within the umbilicus, however, these become a little weaker and more closely spaced. On the base proper the junctions of the axial ribs and spiral threads form slender nodules. Aperture broadly ovate; peristome double, conspicuously expanded all around, the outer forming a rather strong auricle at the posterior angle, less expanded on the posterior half of the outer lip than on the rest, and most expanded on the basal half of the inner lip; the entire outer peristome shows wavy concentric lines; the outer peristome is adnate to the preceding turn on the parietal wall; the inner peristome is somewhat exserted and distinct all around. Operculum thin, paucispiral, with the nucleus halfway between submarginal and subcentral, the outside covered with a thin deposit of fine calcareous granules.

Field notes by Bartsch made on July 27, 1928, describe the animal as follows:

Dorsum pale gray, semitranslucent, with innumerable minute white spots, which are most concentrated about the base of the tentacles and render this area paler than the rest. Edge of snout with a faint olive tinge. Tentacles orange with buffish tip, the latter not expanded. Sides of body and sole of foot gray, with olivaceous tinge. Sole deeply medially cleft; wave motion of the two sides alternate.

The type, U.S.N.M. no. 493032, was collected by John B. Henderson on the north slope of the Sierra de Anafe, Pinar del Rio. It has a little more than 3 whorls and measures: Length, $16.6 \mathrm{~mm}$; greater diameter, $9.6 \mathrm{~mm}$; lesser diameter, $7.9 \mathrm{~mm}$.

The Sierra Anafe has furnished a number of interesting species, and this is another.

The expanded peristome and auriculation at the posterior angle readily distinguish this from the other species that group around pictum, pfeifferianum, poeyanum, and lembeyi.

This suggests Chondropoma (Chondropoma) cabrerai but is at once distinguished in having the whorls much more inflated and much weaker sculpture and in having the posterior angle less conspicuously auriculate.

\section{CHONDROPOMA (CHONDROPOMA) CABRERAI, new species}

Plate 30, Figure 9

Shell elongate-conic, the truncated form has almost a cylindric appearance, pale horn ground color, marked by distantly spaced, inter- 
rupted spiral spots of brown, which are arranged in axial series and make the dark coloration appear more in the nature of axial streaks than spiral elements. On the base, however, this state of affairs is reversed and the brown spots become almost confluent spirally. This color scheme shines through the thin texture of the outer lip and extends over the pale inner and outer peristome, whose ground color is bluish white. Whorls moderately rounded, rather sharply denticulated on the narrow shoulder and marked by feeble, retractively slanting incremental lines and rather strong flattened spiral cords, of which six are present on the first and second of the remaining turns; on the later a finely intercalated slender thread appears in the middle between these and on the last whorl this thread reaches the strength of the rest. The base bears the same sculpture as the spire, but the spiral sculpture of the umbilical wall is much enfeebled, appearing as mere lines. Suture moderately constricted; periphery somewhat infiated, well rounded. Base short, slightly inflated, well rounded. A perture broadly oval; peristome double, the inner slightly exserted, reflected over and adnate to the outer. The inner broadly expanded, more so on the columellar wall than on the basal portion of the outer lip, subauriculate at the posterior angle. Operculum paucispiral, with the nucleus halfway between the marginal and subcentral and covered with a thin deposit of calcareous granules.

The type, U.S.N.M. no. 367793, was collected by Cabrera at El Volcan, south of Managua. It has 3.9 whorls remaining and measures: Length, $15.3 \mathrm{~mm}$; greater diameter, $9.1 \mathrm{~mm}$; lesser diameter, $6.7 \mathrm{~mm}$.

In many ways this species resembles $C$. $(C$.) leon $i$ but differs from it in having the whorls much less inflated and in having the much stronger sculpture.

\section{CHONDROPOMA (CHONDROPOMA) PFEIFFERIANUM (Poey)}

Shell large, when perfect elongate-conic, when truncated very elongate-ovate, varying from flesh-color to chestnut-brown, with darker interrupted spiral bands of brown; the dots composing these are always arranged in both axial and spiral series and usually become confluent axially, giving the shell an axially banded aspect rather than a spirally banded one. Interior of aperture pale brown. Peristome yellowish horn-color with the dark bands showing. Nuclear whorls almost 2, forming a truncated apex, all smooth except the last portion of the last turn, which shows indication of both axial and spiral sculpture. The postnuclear whorls are moderately well rounded, narrowly shouldered at the summit, which is rendered crenulated by slender nodules. These become very irregular, both in strength and spacing on the later turns. The axial sculpture con- 
sists of slender threads on the early whorls which become decidedly enfeebled on the later turns, changing here to mere incremental lines. The spiral sculpture consists of threads, also not strongly developed. The junctions of the axial riblets and spiral threads do not form nodules even on the early turns. Suture narrowly channeled. Periphery well rounded. Base moderately long, somewhat inflated, well rounded, openly moderately broadly umbilicated, marked like the upper portion of the last whorl by incremental lines and spiral threads, those on the umbilical wall equaling those on the outside in strength. The last whorl is usually solute for a slight fraction of a turn. Aperture broadly ovate; peristome double, the outer and inner coextensive on the outer lip, slightly separated on the parietal wall and the basal lip and very strongly so on the inner lip where the outer peristome forms a broadly expanded shelflike element, and the inner projects materially above it at a little less acute angle. Operculum thin, corneous, paucispiral, with the nucleus halfway between submarginal and subcentral, the outside covered with a thin granular deposit.

Of this species Gundlach says ${ }^{10}$ : "Animal pale, the interior of the head and neck somewhat rose-colored, which is also the color of the tentacles whose tip is clay yellow. The body is marked above by whitish spots and darkish dots which form a curved band upon the head below the tentacles and still other dots upon the head become concentrated on the edge and form a V-shaped figure with the angle pointing forward. The upper part of the tentacles is rendered grey by a countless number of blackish atoms."

Poey in dedicating this species differentiates it from $C .(C$. pictum, but he does not mention a type locality. Pfeiffer figures a specimen that plainly shows a member of the complex we now recognize as this subspecies. It probably comes from Mangaro, which we know was one of his collecting grounds.

This is a lowland species, found in the stone fences, under rocks

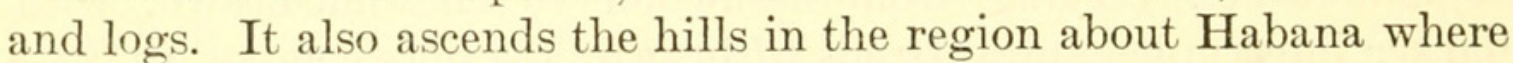
it replaces $C$. $(C$.) pictum.

This species was first collected by Poey at La Loma Tetas de Managua. Pfeiffer later listed it from the Loma Camoa from which he had received specimens collected by Gundlach, and this has been held by some to be the type locality. The typical form, however, must be restricted to Poey's collecting ground, as stated above.

The characteristics of pfeifferianum are a denticulated suture, double lip, usually dark inner lip, and usually a dark tip.

${ }^{10}$ Malakozool. Blätter, vol. 3, pp. 132-133. 
We are recognizing three subspecies, which the following key will help to differentiate:

KEY TO THE SUBSPECIES OF CHONDROPOMA (CHONDROPOMA) PFEIFFERIANUM

Decollated shell more than $14 \mathrm{~mm}$ long.

Shell brown camoense

Shell not brown pfeifferianum

Decollated shell less than $12 \mathrm{~mm}$ long ganuzaense

CHONDROPOMA (CHONDROPOMA) PFEIFFERIANUM CAMOENSE, new subspecies

Plate 30, Figure 1

This subspecies comes from Camoa, Habana Province. It is the largest race and almost always has a chestnut-brown color, only occasionally are brownish horn-color individuals found.

The type, U.S.N.M. no. 493066, has 4.5 whorls remaining and measures: Length, $21.5 \mathrm{~mm}$; greater diameter, $11.1 \mathrm{~mm}$; lesser diameter, $9.8 \mathrm{~mm}$.

\section{CHONDROPOMA (CHONDROPOMA) PFEIFFERIANUM PFEIFFERIANUM Poey}

Plate 30, Figure 2

1851. Cyclostoma pfeifferianum PoEx, Memorias sobre historia natural de la Isla de Cuba, vol. 1, p. 419.

1853. Chondropoma pfeifferianum PFEIFfer, Martini-Chemnitz Conchylien Cabinet, vol. 1 , sect. 19 , p. 374 , pl. 48 , figs. $38-40$.

This, the typical race, we have seen from Chorrera, Managua, La Alianza, Tapaste, Loma de Candella, and Loma de Coca in Habana Province. Here the shell is usually flesh-color, though sometimes pale brown. It is interruptedly spirally banded on spire and base with occasionally a continuous peripheral and subperipheral band of brown. It is easily differentiated from $C$. $(C$.) pfeifferianum camocnse, which is larger and almost always brown. $C$. (C.) pfeifferianum ganuzaense is easily distinguished by its smaller size.

The specimen figured, U.S.N.M. no. 493053, is one received from Poey. It quite closely resembles Pfeiffer's figure. It has 3.6 whorls and measures: Length, $14.5 \mathrm{~mm}$; greater diameter, $8.5 \mathrm{~mm}$; lesser diameter, $7.0 \mathrm{~mm}$.

CHONDROPOMA (CHONDROPOMA) PFEIFFERIANUM GANUZAENSE, new subspecies

Plate 30, Figure 3

This subspecies comes from Ganuza, Habana Province. It is a diminutive race, having all the attributes of $C$. $(C$.$) pfeifferianum$ pfeifferianum except size. 
The type, U.S.N.M. no. 493064, has 3.2 whorls remaining and measures: Length, $11.9 \mathrm{~mm}$; greater diameter, $7.4 \mathrm{~mm}$; lesser diameter, $6.2 \mathrm{~mm}$.

\title{
CHONDROPOMA (CHONDROPOMA) PERLATUM (Gundlach) Poey
}

\author{
Plate 30, Figure 12
}

1858. Cyclostoma perlatum PoEy, Memorias sobre historia natural de la Isla de Cuba, p. 38.

1858. Chondropoma perlaium PFEIfFer, Monographia pneumonopomorum viventium, suppl. 1, p. 144.

Shell elongate-conic, thin, pale horn-color, with interrupted spiral bands of brown; the dots composing these bands are placed at considerable distances apart in the spiral series. They are also arranged in axial series and are present on both spire and base, and show within the aperture, which is a trifle paler inside than outside. Peristome soiled white. At the summit of the whorls there are low, feebly developed, distantly spaced denticles of whitish color. Nuclear whorls 2.2, strongly inflated, rounded and smooth, except the last portion, which shows the feeble beginnings of the postnuclear sculpture. Postnuclear whorls well rounded and marked by rather distantly spaced, acute, slender spiral keels, of which 5 are present on the first of the remaining turns in the specimen described, and 9 on the last turn. The axial sculpture is reduced to mere lines of growth on the last turn, being a trifle stronger on the early turns. Suture moderately constricted. Periphery strongly rounded. Base strongly rounded, narrowly openly umbilicated, and marked like the spire. Interior of the umbilicus also marked by spiral cords, but here they are a little broader and more closely spaced. Aperture broadly ovate, slightly oblique; peristome double, the outer broadly expanded on the inner lip, a little less so on the basal and still less so on the outer lip, not conspicuously auriculated at the posterior angle; on the parietal wall it is very narrow and adnate to the preceding turn; the outer peristome is composed of a series of concentric lamellae; inner peristome a little thicker than the outer, moderately elevated above it, slightly expanded and slightly reflected. Operculum thin, corneous, paucispiral with submarginal nucleus, the outside covered with a thin deposit of fine calcareous granules.

The specimen described and figured, U.S.N.M. no. 493071, is a cotype from District Limonar near Matanzas, Cuba. It has a little more than 4 whorls and measures: Length, $15.2 \mathrm{~mm}$; greater diameter, $9.0 \mathrm{~mm}$; lesser diameter, $7.2 \mathrm{~mm}$. 
The animal of this species was described from a specimen taken by Bartsch on the mogote opposite Mogote Caoba on the east side of the road between Coliseo and Banos de los San Miguel, July 24, 1928.

The animal is short, with the forehead with numerous short streaks and dots of brown, which give it a marbled appearance. The sole of the foot is flesh-color, with a faint grayish suffusion, cleft deeply medially; the motion of the two sides being alternate. The eyes with a whitish ring, which extends to the base of the tentacles. Immediately beyond these the upper surface of the tentacles for half their length is dirty white, while the under part and the rest are orange with a brownish tinge, except the extreme tip, which is slightly expanded and grayish. There is a darker line composed of numerous fine black dots extending from the tentacles backward on the sides. The side of the body is pale ashy gray, the areolations marked by innumerable white dots.

\section{CHONDROPOMA (CHONDROPOMA) PICTUM (Pfeiffer)}

Shell elongate-conic, thin, ranging in color from bluish white through pale straw-color to buff and rather dark purplish brown, unicolor, or marked by interrupted spiral bands of brown, which sometimes become almost continuous. In the dark-colored specimens the bands are obscured but can usually be seen by transmitted light within the aperture. Nuclear whorls almost 2, well rounded, smooth, forming an almost truncated apex. The anterior half of the nuclear turns is pale brown, while the rest is white. Postnuclear whorls well rounded, narrowly shouldered at the summit, marked by obsolete, retractively slanting axial threads and varicial streaks, which are of irregular spacing. At intervals there are obsolete nodulous thickenings of some of the riblets at the summit. The spiral sculpture consists of low rounded threads, which are about as wide as the spaces that separate them. Suture well constricted. Periphery of the last whorl well rounded. Base short, well rounded, narrowly, openly umbilicated, marked by the continuations of the axial sculpture and spiral threads, the latter are here a little less strong than those on the spire, and a little more closely spaced. Both the axial and spiral sculpture are present on the umbilical wall. Aperture moderately large, ovate; peristome simple, slightly expanded and slightly reflected, usually adnate to the preceding turn at the parietal wall. Operculum paucispiral with the nucleus halfway between submarginal and subcentral, the outside covered with a deposit of fine calcareous granules which are laid down in a more or less wavy manner.

This species ranges from Varadero west through Habana to Pinar del Rio Province. It is not confined to paradones but occurs also in 
limestone fences and so has wide distribution. It breaks up into a number of subspecies, which are briefly characterized in the adjoining key.

Field notes on the coloration of the animals of a number of these various races were taken by Bartsch in 1928 and are here reproduced.

\section{Chondropoma (Chondropoma) pictum pictum}

Fundador, Station 2, bluffs of Canimar River below ferry, right side, July 20, 1928.

Animal short, forehead with many short streaks and dots of brown; body behind forehead ashy gray. Ring about base of tentacles pale buff. Tip of mouth a little paler than ring. Tentacles buff below, grayish brown above. The bottom color extends up on the sides. Sides of body and sole of foot ashy gray. Sole of foot deeply medially cleft, locomotion of two sides alternate.

\section{Chondropoma (Chondropoma) pictum mahogani}

Paradones at Rifle range, 2 miles south of Limonar, July 23, 1928.

Animal short, of general buffy tinge, with a dark band across the forehead immediately in front of the tentacles; behind the tentacles it is streaked and spotted with brownish, which gives this part a somewhat marbled effect. Behind this the body is flesh-color, with a pinkish-buff flush, which is also the color of the sides of the body above the foot. Sides of foot pale ashy; sole also ashy but a little paler than the sides, deeply medially cleft. Tentacles buff, with a median dorsal streak of brownish, or in some specimens grayish.

\section{Chondropoma (Chondropoma) pictum yumeriense}

Vista Alegre, July 19, 1928.

Animal short, forehead with many wark short streaks and dots of brown. Edge of snout smoky flesh-color. Tentacles with the base buffish flesh-color, slightly orange beneath, brownish above. Sides of body smoky gray; sole a little paler.

This in coloration seems intermediate between yucayum and pictum from Fundador.

\section{Chondropoma (Chondropoma) pictum celsum}

From Station 19, El Palenque, Matanzas, July 21, 1928.

Animal short with the forehead flesh-color, marked by numerous small, elongate, brownish spots; body behind the forehead soiled flesh-color. Ring about the base of tentacles buff-orange, which is also the color of the tentacles excepting an inner gray core. Tip of tentacles brownish orange. Sides of the body ashy, darkest toward 
the base. Sole of foot pale ashy, deeply medially cleft; motion of two sides alternate.

\section{Chondropoma (Chondropoma) pictum arangoi}

Stone fence between Medoze and Sitio Bonilla, July 28, 1928.

Animal short, flesh-color, with a pinkish flush behind the forehead, which is marked by numerous fine white dots. Sides and sole of foot with a slight smoky suffusion. Tentacles ochraceous, sometimes pale orange.

\section{Chondropoma (Chondropoma) pictum anafense}

Sierra Anafe, July 27, 1928.

Animal short. Forehead and median dorsal parts marbled with conspicuous dots and streaks of brown, less concentrated about the base of the tentacles where the ground color is best shown. Edge of snout a little paler than the adjoining parts. Tentacles orange with the median dorsal part purplish brown. Sides of body, back to tentacles, smoke gray; the rest behind this flesh-color with a pinkish flush. Sole of foot pale gray with an olivaceous tinge.

KEY TO THE SUBSPECIES OF CHONDROPOMA (CHONDROPOMA) PICTUM

Shell very large and thin; average length $23.2 \mathrm{~mm}$ celsum

Shell less large; average length less than $21 \mathrm{~mm}$ and more than

$16 \mathrm{~mm}$.

Outer peristome flaringly expanded anteriorly arangoi

Outer peristome not flaringly expanded anterioriy.

Shell chestnut-brown or orange, rarely paler. gouldianum

Shell not chestnut-brown or orange.

Shell buff with interrupted spiral bands of brown_--_-- mahogani Shell flesh-color with interrupted spiral bands of brown mochense

Shell small.

Shell conspicuously spirally banded.

Ground color varying from buff to chestnut-brown yumeriense Ground color not varying from buff to chestnut-brown.

Ground color flesh-color.

Spiral threads strong. pictum

Spiral threads feeble.

Average length more than $18 \mathrm{~mm}$ anafense

Average length less than $13 \mathrm{~mm}$ sagra

Shell not conspicuously spirally banded. varaderense

CHONDROPOMA (CHONDROPOMA) PICTUM VARADERENSE, new subspecies

Plate 29, Figure 8

This, the easternmost race, comes from Varadero, of the Hicaco Peninsula. It is a small race, of very pale flesh-color with scarcely any indications of spiral color marking. The peristome is almost as 
expanded as in $C$. $(C$.) pictum arangoi and decidedly thickened all around.

The type, U.S.N.M. no. 493090, has a little more than 3 whorls remaining and measures: Length, $16.9 \mathrm{~mm}$; greater diameter, 10.5 $\mathrm{mm}$; lesser diameter, $8.6 \mathrm{~mm}$.

\title{
CHONDROPOMA (CHONDROPOMA) PICTUM PICTUM (Pfeiffer)
}

\author{
Plate 29, Figure 2
}

1839. Cyclostoma pictum Pferffer, Wieg. Archiv. Naturg., vol. 1, p. 356.

1846. Cyclostoma pictum PFEIFFER, Martini-Chemnitz Conchylien Cabinet, vol. 1, sect. 19 , p. 125 , pl. 15 , figs. $1-11$; pl. A, figs. $4-5$.

This, the typical race, was described by Pfeiffer from Fundador. He, like ourselves, found it quite abundant on the limestone bluffs of the Canimar River nearby.

It is a small race, rather strongly sculptured, of flesh-color ground color with the merest tinge of yellow, resembling $C$. $(C$.) pictum yumeriense but having a much more thickened peristome, in which it resembles the much larger $C$. $(C$.) pictum mahogani.

The specimen figured, U.S.N.M. no. 384845 , has 4.5 whorls remaining and measures: Length, $19.2 \mathrm{~m}$; greater diameter, $11.0 \mathrm{~m}$; lesser diameter, $9.2 \mathrm{~mm}$.

\section{CHONDROPOMA (CHONDROPOMA) PICTUM MAHOGANI (Gould)}

Plate 29, Figure 1

1842. Cyclostoma mahogani Gould, Journ. Boston Soc. Nat. Hist., vol. 4, cover of part 1.

1844. Cyclostoma mahogani Gould, Journ. Boston Soc. Nat. Hist., vol. 4, p. 495.

This name subsequent to its introduction has met with unfortunate vicissitudes. It was based upon specimens collected by Bartlett, an engineer, at a sugar central near Limonar. Bartlett probably marked them Caoba, the name of a place very close to Limonar. Caoba is the Spanish name for mahogany, hence Gould's name mahogani, which has nothing to do with the coloration of the shell. A misinterpretation of this fact has caused confusion of this race with $C$. (C.) pictum gouldianum and $C$. (C.) p.yumeriense.

In this race the shell is rather large, ground color pale buff, which is also the color of the peristome. Interrupted spiral bands of brown mark the spire and, to a slightly lesser degree, the base. It resembles most near $C$. $(C$.) pictum mochense, but that subspecies is thinner and has flesh-colored ground color and peristome. The differences in the color of the animal are shown under the specific description.

The specimen figured, U.S.N.M. no. 493092, has 4.5 whorls remaining and measures: Length, $24.1 \mathrm{~mm}$; greater diameter, $14.0 \mathrm{~mm}$; lesser diameter, $11.8 \mathrm{~mm}$. 
We have seen specimens of this race from Caoba, the Paradones at Esmeralda north of the pass near Coliseo, Sierra Descansia, hill next the cemetery at Coliseo, Paradones east of the pass at Coliseo, and the Paradones at the rifle range at Limonar.

CHONDROPOMA (CHONDROPOMA) PICTUM YUMERIENSE, new subspecies

Plate 29, Figure 6

This small race, which occupies the Yumeri Valley near Matanzas and is particularly abundant at the Vista Alegre, has in the past been confused with typical $C$. $(C$.) pictum pictum, from which it is readily distinguished by its weaker sculpture and much less thickened peristome, as well as by its much greater range of color. The ground color here ranges from fiesh-color to chestnut-brown. Specimens of this last color resemble $C$. $(C$.) pictum gouldianum (Poey) but lack the orange lip and are much smaller. Interrupted spiral bands of brown are present on spire and base.

We have figured the type and two specimens to show the range of coloration. The type, U.S.N.M. no. 499602, a complete specimen, has 7.0 whorls and measures: Length, $17.8 \mathrm{~mm}$; greater diameter, $9.3 \mathrm{~mm}$; lesser diameter, $7.6 \mathrm{~mm}$.

\section{CHONDROPOMA (CHONDROPOMA) PICTUM GOULDIANUM (Poey)}

\section{Plate 29, Figure 10}

1854. Cyclostoma gouldianum PoEx, Memorias sobre historia natural de la Isla de Cuba, vol. 1, p. 419.

1858. Cyclostoma gouldianum PoEy, Memorias sobre historia natural de la Isla de Cuba, vol. 2, pp. 43-44.

This beautiful race was well defined by Poey, but like others it has been confused by contemporary and subsequent students with $C$. $(C$.) pictum pictum, from which its much larger size and splendid shining chestnut-brown, or at times orange, coloration and orange-colored peristome strikingly differentiate it. It occupies the Abra de Figuroa and Loma Mena of the lower Yumeri Valley.

The specimen figured, U.S.N.M. no. 493037, one of a large series, comes from the Abra de Figuroa. It has a little more than 4 whoris remaining and measures: Length, $26.1 \mathrm{~mm}$; greater diameter, 15.1 $\mathrm{mm}$; lesser diameter, $12.3 \mathrm{~mm}$.

CHONDROPOMA (CHONDROPOMA) PICTUM CELSUM, new subspecies

\section{Plate 29, Figure 9}

This huge race we have collected on the north side of El Palenque, where it extends from the eastern end west through the Sierra Cama$66879-38-10$ 
rones. The shells here are much larger than any we have seen elsewhere, of flesh-color or pale buff ground color, with rather broad interrupted spiral color bands.

The type, U.S.N.M. no. 493040, comes from El Palenque. It has a little more than 4 whorls remaining and measures: Length, 28.0 $\mathrm{mm}$; greater diameter, $16.9 \mathrm{~mm}$; lesser diameter, $13.5 \mathrm{~mm}$. This is an unusually large individual; in contrast to it we may cite the average measurements of a series of specimens from El Palenque: Number of whorls, 3.8; length, $24.2 \mathrm{~mm}$; greater diameter, $15.6 \mathrm{~mm}$; lesser diameter, $11.4 \mathrm{~mm}$.

\section{CHONDROPOMA (CHONDROPOMA) PICTUM MOCHENSE, new subspecies}

Plate 29, Figure 3

The shells that cluster about Ceiba Mocha, a few miles south of El Palenque, resemble $C$. $(C$.) pictum celsum in coloration but are much smaller and have the peristome much less thickened at the edge.

The type, U.S.N.M. no. 493044, a complete specimen, has 6 whorls, and measures: Length, $22.7 \mathrm{~mm}$; greater diameter, $12.2 \mathrm{~mm}$; lesser diameter, $10.3 \mathrm{~mm}$. A large series of specimens gives the following average measurements: Length, $17.8 \mathrm{~mm}$; greater diameter, $10.5 \mathrm{~mm}$; lesser diameter, $8.9 \mathrm{~mm}$.

\section{CHONDROPOMA (CHONDROPOMA) PICTUM SAGRA (Orbigny)}

\section{Plate 29, Figure 5}

1842. Cyclostoma sagra OrBIGNY, in Sagra's Histoire physique, politique et naturelle de l'Ile de Cuba, vol. 1, p. 263, pl. 22, figs. 21, 23.

Orbigny cites "environs de la Havana" as locality for his Cyclostoma sagra. Our specimens from Cojimar, a little south of Habana, appear to satisfy his description and figures.

It is a small race, with the sculpture decidedly enfeebled, in which respect it resembles $C$. $(C$.) pictum anafense, from which it is distinguished by its smaller size.

The specimen figured, U.S.N.M. no. 493083, has 3.3 whorls remaining and measures: Length, $13.9 \mathrm{~mm}$; greater diameter, $8.0 \mathrm{~mm}$; lesser diameter, $7.5 \mathrm{~mm}$.

\section{CHONDROPOMA (CHONDROPOMA) PICTUM ARANGOI, new subspecies}

Plate 29, Figure 11

This subspecies ranges through the Sitio Bonilla, Sitio Perdido, Escalera de Jaruco, and Tapaste.

It is a rather large pale-colored race that has the outer lip rather flaringly expanded and reflected. The type, U.S.N.M. no. 499601, 
comes from Sitio Bonilla, Jaruco, and has a little more than 4 whorls remaining, which measure: Length, $23.7 \mathrm{~mm}$; greater diameter, 14.2 $\mathrm{mm}$; lesser diameter, $11.0 \mathrm{~mm}$.

CHONDROPOMA (CHONDROPOMA) PICTUM ANAFENSE, new subspecies

Plate 29, Figure 4

This subspecies ranges from the Sierra Anafe, through Guanajay to Artemisa.

In its enfeebled sculpture this race resembles $C$. (C.) pictum sagra, from which its larger size will distinguish it.

The type, U.S.N.M. no. 493084 comes from the side of Loma de Anafe. It has a little more than 3 whorls remaining and measures: Length, $16.3 \mathrm{~mm}$; greater diameter, $9.7 \mathrm{~mm}$; lesser diameter, $7.9 \mathrm{~mm}$.

CHONDROPOMA (CHONDROPOMA) YUCAYUM (Presas) Pfeiffer

Plate 29, Figure 7

1863. Chondropoma yucayum (Presas) PfeIfFer, Malakozool. Blätter, vol. 10, p. 190.

Shell large, short, stout, broadly conic, ranging from flesh-color to pale purple, sometimes unicolor, but usually with interrupted spiral bands of brown, of which the one at the summit is a little broader than the rest, equaling in width the one immediately below the subperipheral on the base. These interrupted spiral bands are arranged in axial as well as spiral series. The interior of the aperture varies in color with the intensity of the outer coloration, the peristome usually being yellowish white. Nuclear whorls 2, well rounded, smooth, forming a rather blunt apex. Postnuclear whorls strongly rounded, inflated, very narrowly shouldered, almost appressed at the summit and marked by numerous low, rounded spiral threads, which are a little wider than the spaces that separate them. In addition to this, there are obsolete, retractively slanting axial threads and finer incremental lines. At irregular intervals there are also varicial axial streaks. At the summit at irregular intervals there are a few scattered ill-defined denticles representing thickenings of some of the ribs. These are best developed on the early turns. Periphery strongly rounded. Base short, inflated, strongly rounded, openly umbilicated, marked with sculpture like that characterizing the spire. The sculpture on the umbilical wall is a little weaker than the rest. Aperture large, ovate; peristome double, the outer slightly expanded and reflected, the inner almost as broad as the outer and also somewhat expanded and reflected. Operculum paucispiral with submarginal nucleus, the outside covered with a rather thick deposit of rather coarse calcareous granules. 
The two specimens, U.S.N.M. no. 29054, were collected by C. Wright. They have 3.8 and 3.6 whorls remaining and measure, respectively: Length, 22.7 and $19.8 \mathrm{~mm}$; greater diameter, 14.7 and $13.4 \mathrm{~mm}$; lesser diameter, 12.2 and $11.6 \mathrm{~mm}$.

This species was described by Presas from the Playa de Indios. (Yudios), Matanzas. It is narrowly confined to the region south of the river at Matanzas, extending to the hilltop at Bellamar Cave.

Of the animal of this Bartsch has made the following description:

Animal short, forehead marked by numerous short streaks and spots of brown, which give to it a somewhat marbled appearance. Behind this the body is flesh-color, with a buffish tinge. The edge of the forehead, ring about the eyes, and a narrow triangular area behind these are pinkish buffish. Snout gray, a little paler at the edge of its fork. Tenacles pinkish at base, the rest coral red with a brownish flush on the upper side. Sides of body smoky gray, as lighter median streak between snout and cleft in sole on upper side. Sole smoky gray, deeply medially cleft; motion alternate on the two sides. Under side of body behind operculum flesh-color.

The chubbiness and shortness of the shell distinguish this from $C$. (C.) pictum, from which it is also differentiated by its anatomic characters.

CHONDROPOMA (CHONDROPOMA) COGNATUM, new species

Plate 30, Figure 4

Shell of medium size, elongate-conic, thin, semitranslucent, horncolor, with interrupted spiral bands of brown. The spots composing these bands are arranged in both axial and spiral series. Nuclear whorls almost 2, smooth except the last portion of the last turn, which shows faint incremental lines. All the nuclear whorls are of plain color. Postnuclear whorls narrowly tabulatedly shouldered at the summit, marked by retractively slanting, threadlike axial riblets, which are rather strong on the early whorls but become enfeebled on the last turn. These threads are about one-third to one-fourth as wide as the spaces that separate them. They become somewhat expanded at the summit and render this rather conspicuously denticulated. The spiral sculpture consists of slender, low, rounded threads, which are of almost the same width and about one-half to one-third as wide as the spaces that separate them. Suture slightly channeled. Periphery of the last whorl well rounded. Base short, well rounded, openly umbilicated, marked by the continuations of the axial riblets, which here become emphasized as do the spiral threads which, while a little narrower and somewhat wavy, are nevertheless much stronger than those of the spire. Both the axial and spiral seulpture extend within the umbilicus. Aperture large, broadly oval; peristome 
simple, slightly expanded and reflected, that of the parietal wall usually free. Operculum thin, paucispiral, with the nucleus almost submarginal, the outside covered with a thin deposit of fine calcareous granules.

The type, U.S.N.M. no. 11008, was collected by C. Wright in the jurisdiction of Colon. It has a little over 4 whorls and measures: Length, $19.9 \mathrm{~mm}$; greater diameter, $11.1 \mathrm{~mm}$; lesser diameter, 8.7 $\mathrm{mm}$.

The specimens before us show great diversity in size, and it is most probable that the smaller ones represent the males. This species, which at first sight suggests $C$. $(C$.$) pictum by its general form and$ simple peristome, is nevertheless so widely separated from it that we do not hesitate to give it specific rank. The much stronger axial sculpture, the narrow channeled suture, and the numerous fine denticles at the summit easily separate it from the pictum group.

\section{CHONDROPOMA (CHONDROPOMA) VESPERTINUM Morelet}

Shell elongate-conic. The ground color may be flesh-color or pale horn-color, or pale brown, or with purplish tinge. In addition to this, there are interrupted spiral bands of brown both on spire and base, of varying width, intensity, and spacing. The axial riblets are usually a little stronger at the summit, where they terminate as slender white denticles. The inside of the umbilical wall is of a brownish purple, interior of aperture varying with the intensity of the coloration on the outside, but at all times showing the spiral bands where present on the inside of the outer lip. Peristome almost white. The plug at the truncated end usually shines through the substance of the shell as a dark oblique band. Nuclear whorls 2, inflated, well rounded, smooth, except the last portion of the last whorl, which shows the fine beginning of the postnuclear sculpture, forming an almost flattened apex, narrowly shouldered at the summit. Postnuclear whorls marked by feeble, threadlike, retractively slanting, rather closely spaced, axial riblets, which are strongest at the summit which they render finely denticulate. In addition to this, the whorls are marked by slender, low, rounded spiral threads, which are considerably stronger than the axial riblets. These two elements give to the shell a finely fenestrated aspect. Suture rendered rather constricted by the slight shoulder at the summit. Periphery strongly rounded. Base well rounded, openly umbilicate, marked by the continuation of the axial riblets and spiral threads, which are as strong as those on the spire. Within the umbilicus, however, the spiral threads become finer and a little more closely spaced. Last whorl solute for about one-tenth of a turn. A perture oval, posterior angle rather acute; peristome simple, slightly expanded, and slightly reflected. Operculum thin, paucispiral, with almost submarginal nu- 
cleus, the outside marked by a thin deposit of fine calcareous granules.

This species comes from the mountains of the central north coast of the Isle of Pines. Here we have on the west the Sierra Casas and facing it across the river some two miles distant, the Sierra Caballas, while to the north of this is the Sierra Colombo, and about 3 miles northeastward is the Sierra Bibijagua. All these isolated blocks harbor distinct races, which we here recognize.

Of the animal of Chondropoma (Chondropoma) dissolutum, Gundlach ${ }^{11}$ says: Animal whitish, especially the tentacles and snout, neck flesh-color. Head with a purplish tinge. The tip of the tentacles a little thicker and brownish. Head and neck grayish but with many black dots which form a $\mathrm{V}$-shaped area upon the head behind the base of the tentacles, and a second similar one behind the snout, which becomes darker posteriorly.

Torre has examined Morelet's types of Cyclostoma vespertinum in the British Museum and of them he says: "Three specimens so labeled in Morelet's handwriting. They are, however, the same as Chondropoma dissolutum Pfeiffer from the Isle of Pines. The locality Palenque, Mexico, is evidently a mistake."

Pfeiffer's Chondropoma dissolutum must, therefore, give way to the older Chondropoma vespertinum Morelet.

Distribution of the subspecies of $C$. $(C$.) vespertinum is shown in figure 100 .

KEY TO THE SUBSPECIES OF CHONDROPOMA (CHONDROPOMA) VESPERTINUM

Shell prevailingly brown.

Length of decollated shell more than $19 \mathrm{~mm}$ vespertinum

Length of decollated shell less than $17 \mathrm{~mm}$ colombense Shell prevailingly flesh-color.

Shell very thin. bibijaguense

Shell not very thin caballosense

CHONDROPOMA (CHONDROPOMA) VESPERTINUM VESPERTINUM Morelet

Plate 30, Figure 14

1851. Chondropoma vespertinum Morelet, Testacea novissima insula Cubanae et Americae Centralis, pt. 2, p. 19.

1854. Chondropoma dissolutum Pfeiffer, Malakozool. Blätter, vol. 2, pp. 158-159. 1858. Chondropoma dissolutum Premfer, Novitates conchologicae, vol. 1, p. 95, pl. 26, figs. 12-16.

We have discussed the use of the name $C$. $(C$.) vespertinum of Morelet, who does not help us in the restriction of it to a definite subspecies except that we know from his Helicina constellata that he collected in the Sierra Casas. Pfeiffer's figures of $C$. (C.) dissolutum also

11 Malakozool. Blätter, vol. 3, p. 130, 1856. 
argue for such a restriction. For this reason we now restrict the typical form to the Sierra Casas race.

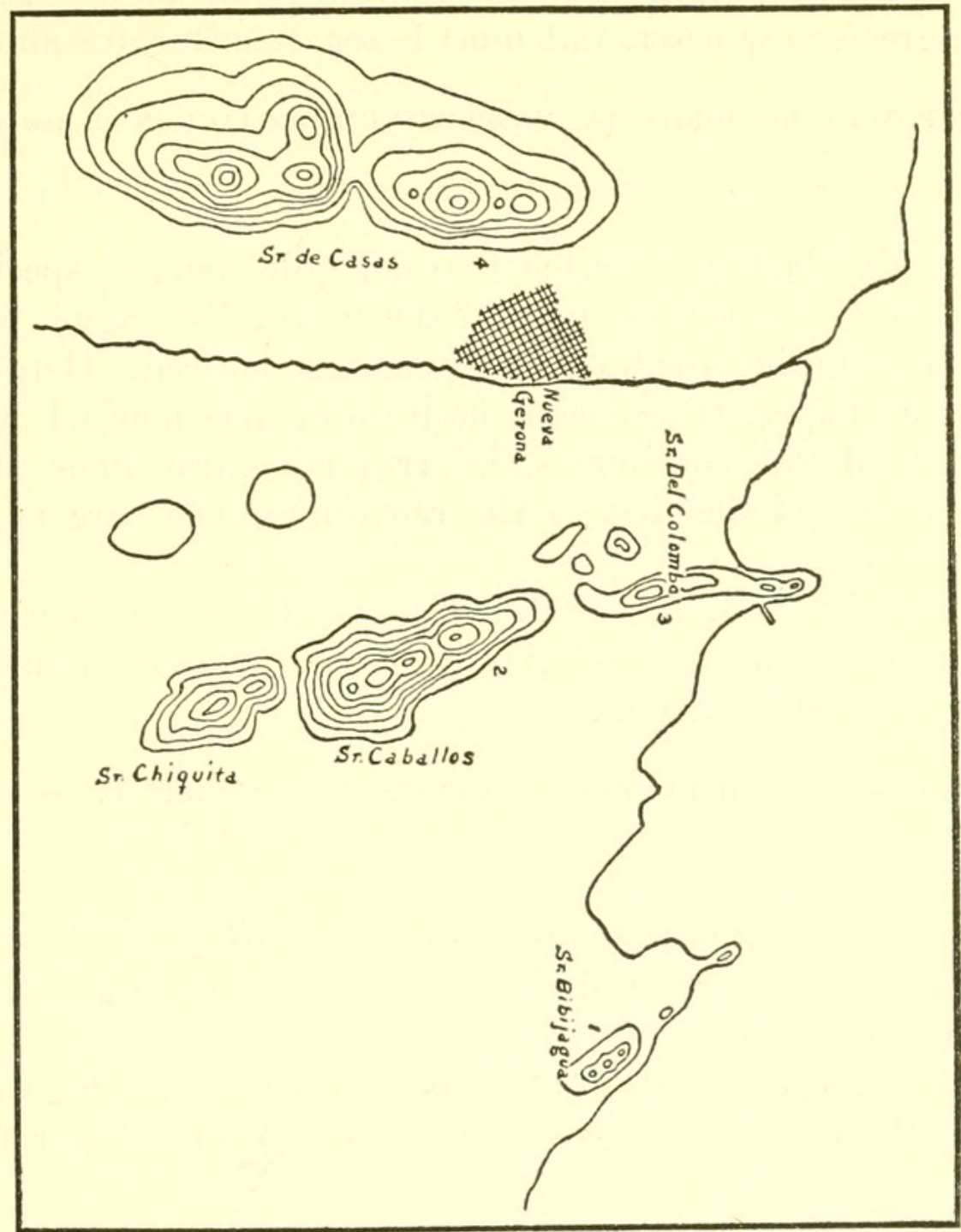

FIGURE 100.-Distribution of the subspecies of Chondropoma (Chondropoma) vespertinum: (1) bibijaguense; (2) caballosense; (3) colombense; (4) vespertinum.

In this subspecies the dark forms prevail; it is stouter than $C .(C$.) vespertinum colombense but less so than $C$. $(C$.) vespertinum caballosense.

The specimen figured, U.S.N.M. no. 493139, has a little more than 4 whorls remaining and measures: Length, $19.1 \mathrm{~mm}$; greater diameter, $10.3 \mathrm{~mm}$; lesser diameter, $8.8 \mathrm{~mm}$.

It comes from immediately behind Nueva Gerona. Specimens from the southern end of the range are not differentiated.

CHONDROPOMA (CHONDROPOMA) VESPERTINUM CABALLOSENSE, new subspecies

Plate 30, Figure 13

Shell larger, a little thinner, and paler than $C$. $(C$.) vespertinum vespertinum, which renders the interrupted spiral bands more conspicuous. 
The type, U.S.N.M. no. 499609, comes from the west side of the center of the main range, south of the road leading to the Presidio. It has a little more than 4 whorls remaining and measures: Length, $20.8 \mathrm{~mm}$; greater diameter, $12.1 \mathrm{~mm}$; lesser diameter, $9.8 \mathrm{~mm}$.

CHONDROPOMA (CHONDROPOMA) VESPERTINUM BIBIJAGUENSE, new subspecies

Plate 30, Figure 16

Of this race Bartsch collected two not quite perfect specimens on the west side of the central part of the Sierra Bibijagua, which are so different from the others that they must be noticed. Here the shell is as thin as paper, translucent, flesh-color, and marked with very conspicuous, almost continuous, interrupted spiral lines of brown. The columella and the first of the remaining turns are brown; the peristome is white.

The type, U.S.N.M. no. 499611, has a little more than 4 whorls remaining and measures: Length, $16.4 \mathrm{~mm}$; greater diameter, 11.2 $\mathrm{mm}$; lesser diameter, $8.8 \mathrm{~mm}$.

CHONDROPOMA (CHONDROPOMA) VESPERTINUM COLOMBENSE, new subspecies

Plate 30, Figure 15

This race comes from the northwestern end of the Sierra Colombo. It is a dark race like typical $C .(C$.) vespertinum vespertinum, but smaller and slenderer.

The type, U.S.N.M. no. 493144, has 5 whorls remaining and measures: Length, $17.0 \mathrm{~mm}$; greater diameter, $9.6 \mathrm{~mm}$; lesser diameter, $7.3 \mathrm{~mm}$.

\section{CHONDROPOMA (CHONDROPOMA) WILCOXI Pilsbry and Henderson}

\section{Plate 31, Figure 7}

1912. Chondropoma wilcoxi Pilsbry and Henderson, Nautilus, vol. 26, p. 45.

Shell elongate-conic; when truncated elongate-ovate; pale brown, with interrupted spiral bands of brown a trifle darker than the ground color. The dots composing these bands are rather distantly spaced and are arranged in both axial and spiral series. The interrupted spiral bands of brown are only feebly indicated on the base. The peristome is a little paler than the ground color. Nuclear whorls 2, dark chestnut-brown, the first one being more intensely so than the rest, smooth, strongly rounded, forming an almost flattened apex, the last portion of the last turn shows traces of the beginning of the axial threads. Postnuclear turns well rounded, narrowly shouldered at the summit, marked by slender, retractively slanting, narrow axial riblets, which extend prominently to the summit; in 
fact they are a little stronger on the narrowly shouldered summit than on the rest of the turn, appearing here as low lamellae. The spiral sculpture consists of rather strong broad cords, which are a little narrower than the spaces that separate them. There are 7 of these on the first of the remaining turns between summit and suture and 18 on the last immediately behind the peristome. The junctions of the axial riblets and spiral cords form slender tubercles whose long axis is parallel with the axial sculpture. Suture slightly channeled. Periphery of the last whorl inflated, well rounded. Base moderately long, inflated, well rounded, narrowly umbilicated, marked by the continuations of the axial riblets and spiral cords, the latter of about the same strength as those on the spire but a little more distantly spaced near the umbilicus. The umbilical wall is also marked by spiral cords, but here they are a little more closely spaced and a little less strongly developed than those outside of the umbilicus. Aperture broadly oval; peristome double, the outer forming a narrow auricle at the posterior angle, and here consists of a series of concentric lamellae; on the rest of the aperture it extends but slightly beyond the peristome, a little more so on the inner lip than on the outer; the inner peristome is rather strongly developed, thickened and slightly reflected, and but slightly exserted above the inner. Operculum paucispiral, with submarginal nucleus, the outside covered with a rather thick deposit of fine calcareous granules.

The specimen described and figured, U.S.N.M. no. 493145, is a cotype collected by John B. Henderson at Rosario, Ensenada de Cochinas, on the south coast of Cuba. It has a little more than 4 whorls remaining and measures: Length, $19.0 \mathrm{~mm}$; greater diameter, $11.6 \mathrm{~mm}$; lesser diameter, $9.3 \mathrm{~mm}$.

\section{CHONDROPOMA (CHONDROPOMA) NICOLASI, new species}

Shell of medium size, the truncated specimens ovate; when complete elongate-conic, horn-color or white, unicolor or marked with inconspicuous, interrupted spiral bands of brown. The elements composing these bands are arranged in both axial and spiral series; axially they are rather distantly spaced. The peristome is almost the same color as the ground color of the shell, being only a very little paler. Nuclear whorls about 2, forming a somewhat flattened apex; the first part smooth, the last showing the beginning of the postnuclear sculpture. Postnuclear whorls are strongly rounded, almost inflated, and narrowly shouldered at the summit, marked by slender, retractively slanting, axial, threadlike riblets, which become slightly expanded into flattened crenulations at the summit. The spiral sculpture consists of rather strong cords, which are not quite so wide as the spaces that separate them. The junctions of the axial 
threads and the spiral cords form slender nodules whose long axis is parallel with the axial sculpture, but these nodules are not at all conspicuous. Suture strongly constricted, narrowly channeled. Periphery of the last whorl inflated, well rounded. Base short, inflated, well rounded, narrowly openly unbilicate, marked by the continuation of the obsolete axial riblets and spiral cords. The latter are of about the same strength as those on the spire, those on the inside of the umbilical wall being almost as strong as those outside of it. Aperture ovate with an inconspicuous auricle at the posterior angle; peristome double, the outer is reflected obliquely and marked by a series of concentric lines at the auricle and the inner lip; the inner is smooth, also expanded and reflected, almost extending to the outer limit of the outer on the outer lip, while on the inner and basal lip the outer peristome is quite a little broader. Operculum paucispiral, with subcentral nucleus, the outside covered with a rather thick deposit of calcareous granules.

This species appears confined to the Isle of Pines, where we are recognizing three subspecies.

KEY TO THE SUBSPECIES OF CHONDROPOMA (CHONDROPOMA) NICOLASI

Spiral sculpture strong johnsoni Spiral sculpture feeble.

Ground color brown brittoni

Ground color flesh-color nicolasi

CHONDROPOMA (CHONDROPOMA) NICOLASI NICOLASI, new subspecies

Plate 31, Figure 6

1916. Chondropoma wilcoxi Henderson, Ann. Carnegie Mus., vol. 10, p. 316 (in part).

This race was collected at Carapatchibey, Isle of Pines, by Dr. Nicolas. It has a flesh-colored ground color, with faint interrupted spiral lines of brown, which appear more like axial streaks than spiral elements. The sculpture is stronger than that of $C$. (C.) nicolasi brittoni and less strong than that of $C$. (C.) nicolasi johnsoni.

The type, U.S.N.M. no. 493148 , has a little more than 4 whorls remaining and measures: Length, $14.8 \mathrm{~mm}$; greater diameter, $8.2 \mathrm{~mm}$; lesser diameter, $7.2 \mathrm{~mm}$.

CHONDROPOMA (CHONDROPOMA) NICOLASI BRITTONI, new subspecies

Plate 31, Figure 4

This race was collected by Hermano Leon on the Jorobado Peninsula, Isle of Pines. It has a brown ground color, with decidedly feeble sculpture. 
The type, U.S.N.M. no. 493150, has 4.5 whorls remaining and measures: Length, $16.7 \mathrm{~mm}$; greater diameter, $9.9 \mathrm{~mm}$; lesser diameter, $7.9 \mathrm{~mm}$.

\section{CHONDROPOMA (CHONDROPOMA) NICOLASI JOHNSONI, new subspecies}

Plate 31, Figure 5

This is the smallest race of this species known. The specimens before us of this race were collected by Mr. Johnson and bear the label "Isle of Pines" without specific locality.

Shell white, with the merest indication in places of interrupted brown spiral lirations. The sculpture is much stronger than that of the other two subspecies.

The type, U.S.N.M. no. 499612, is a complete specimen, which has 7.5 whorls and measures: Length, $16.5 \mathrm{~mm}$; greater diameter, $8.0 \mathrm{~mm}$; lesser diameter, $7.4 \mathrm{~mm}$.

\section{CHONDROPOMA (CHONDROPOMA) CARENASENSE Pilsbry and Henderson}

Shell elongate-conic, or when truncated elongate-ovate, pale brown, marked by interrupted spiral bands of brown, which are arranged in both axial and spiral series. Peristome white. Nuclear whorls almost 2 , forming a somewhat truncated apex, the first smooth, the last portion of the last showing indications of both axial and spiral sculpture. Postnuclear whorls narrowly channeled at the summit, which is rendered crenulated by the strong extension of the axial ribs, which are moderately distantly spaced, retractively slanting, and well developed. The spiral sculpture consists of spiral threads a trifle stronger than the axial riblets and increase in number with the whorls. The junctions of the axial ribs and spiral threads form rounded nodules, which vary in strength with the strength of the spiral threads, the latter varying according to the intercalation of the newer elements. Suture narrowly channeled. Periphery of the last whorl well rounded. Base well rounded, slightly inflated, very narrowly umbilicate, the umbilicus almost covered by the reflection of the outer peristome of the inner lip. The base is marked by the continuations of the axial and spiral threads, which are about as strong as those of the spire, those within the umbilicus being a trifle weaker. Aperture broadly oval; peristome conspicuously double, the outer expanded somewhat flaringly, forming a conspicuous auricle at the posterior angle and adnate to the preceding turn at the parietal wall; the inner projecting decidedly above the outer, mostly so on the outer lip. Operculum corneous, paucispiral, with submarginal nucleus, the outside covered with a thin deposit of fine calcareous granules. 
The species apparently ranges along the shoreline from Cayo Carenas of Cienfuegos Bay to Corrientes Bay at the west end of the island. It was also found present on Cayo Cantilles, east of the Isle of Pines. A number of races are recognizable.

KEY TO THE SUBSPECIES OF CHRONDROPOMA (CHONDROPOMA) CARENASENSE Diameter of shell more than $7 \mathrm{~mm}$.

Peristome white.

Sculpture very fine toroense

Sculpture not very fine carenasense

Peristome yellow corrientesense Diameter of shell less than $6 \mathrm{~mm}$.

Peristome white.

Sculpture very fine guauraboense

Sculpture not very fine rosariense

Peristome yellow cantillense

CHONDROPOMA (CHONDROPOMA) CARENASENSE TOROENSE, new subspecies Plate 32, Figure 3

This subspecies, which comes from Cabeza del Toro near Bahia de Cochinos, resembles in general shape $C .(C$.$) carenasense carenasense$ but is even more globose, with the axial ribs much more closely approximated, the spiral sculpture with many more threads, and the interrupted spiral lines more numerous.

The type, U.S.N.M. no. 367796, has 4 whorls remaining and measures: Length, $13.0 \mathrm{~mm}$; greater diameter, $8.0 \mathrm{~mm}$; lesser diameter, $6.5 \mathrm{~mm}$.

\section{CHONDROPOMA (CHONDROPOMA) CARENASENSE CARENASENSE Pilsbry and Henderson}

Plate 32, Figure 2

1912. Chondropoma carenasense Pilsbry and Henderson, Nautilus, vol. 26, p. 44.

This race comes from Cayo Carenas and the adjacent mainland. Here the shells are large, flesh-color or white, with the interrupted spiral bands forming axial streaks that are more conspicuous than the spiral lines. The sculpture is more pronounced than in any of the other races, the intersection of the axial ribs and spiral threads forming well-defined cusps.

A cotype, U.S.N.M. no. 493151, has 4.5 whorls remaining and measures: Length, $14.2 \mathrm{~mm}$; greater diameter, $8.0 \mathrm{~mm}$; lesser diameter, $7.2 \mathrm{~mm}$.

CHONDROPOMA (CHONDROPOMA) CARENASENSE CORRIENTESENSE, new subspecies

Plate 32, Figure 1

This race, which comes from Corrientes Bay at the western end of Cuba, is as large as $C .(C$.$) carenasense carenasense, but the shells$ 
are much more conic in outline, much less strongly crenulated at the summit, and much darker, with the peristome yellow. The sculpture is also finer than $C$. $(C$.) carenasense toroense and more regular.

The type, U.S.N.M. no. 499613, is a complete specimen of 7.5 whorls and measures: Length, $15.2 \mathrm{~mm}$; greater diameter, $7.7 \mathrm{~mm}$; lesser diameter, $6.2 \mathrm{~mm}$.

CHONDROPOMA (CHONDROPOMA) CARENASENSE GUAURABOENSE, new subspecies

Plate 32, Figure 5

This is a small race of yellow or buff color, except the peristome, which is white. The interrupted spiral bands are inconspicuous, and the sculpture is much more closely spaced than in $C$. $(C$. $)$ carenasense carenasense.

The type, U.S.N.M. no. 104488, has almost 4 whorls remaining and measures: Length, $9.3 \mathrm{~mm}$; greater diameter, $5.6 \mathrm{~mm}$; lesser diameter, $4.5 \mathrm{~mm}$. It comes from Boca de Guaurabo.

CHONDROPOMA (CHONDROPOMA) CARENASENSE ROSARIENSE, new subspecies

Plate 32, Figure 6

This race comes from Rosario about 15 miles west of Cabeza del Toro. It is exceedingly variable in size. Specimens even slenderer than $C .(C$.$) carenasense guauraboense may be found, and from this$ they increase in size to half that of $C .(C$.$) carenasense carenasense.$ Like carenasense the sculpture is sharply cusped.

The type, U.S.N.M. no. 493160, has 5 whorls remaining and measures: Length, $12.0 \mathrm{~mm}$; greater diameter, $6.1 \mathrm{~mm}$; lesser diameter, $5.5 \mathrm{~mm}$.

A complete specimen of 7.1 whorls, on the other hand, measures only: Length, $11.5 \mathrm{~mm}$; greater diameter, $5.3 \mathrm{~mm}$; lesser diameter, $4.4 \mathrm{~mm}$.

CHONDROPOMA (CHONDROPOMA) CARENASENSE CANTILLENSE, new subspecies

Plate 32, Figure 7

This race was collected by Bartsch on Cayo Cantilles east of the Isle of Pines. It equals in size the average of $C$. $(C$.) carenasense rosariense but is much more yellowish, with yellow peristome and with much finer and more numerous axial and spiral sculptural elements.

The type, U.S.N.M. no. 499614, has a little more than 4 whorls remaining and measures: Length, $11.5 \mathrm{~mm}$; greater diameter, 5.9 $\mathrm{mm}$; lesser diameter, $5.4 \mathrm{~mm}$. 


\section{CHONDROPOMA (CHONDROPOMA) OBESUM (Menke)}

Shell elongate-conic when complete or elongate-ovate when truncated, varying in color from gray to orange, white or pale yellow. Nuclear whorls almost 2, forming a blunt apex, the first smooth, the last with indications of the postnuclear sculpture. Postnuclear whorls inflated, strongly rounded, almost appressed at the summit, marked by slender, retractively curved, axial threads and spiral lirations, the latter a little stronger than the axial threads. The junctions of the two form slender nodules. Suture strongly constricted. Periphery strongly rounded. Base short, inflated, well rounded, openly umbilicate, and marked like the spire. The last whorl appressed to the preceding turn. Aperture broadly oval; peristome double, the outer best shown at the posterior auricle and on the inner lip, the inner peristome is coextensive with the outer. Operculum paucispiral with submarginal nucleus, the outside covered with a thin deposit of fine calcareous granules.

This is a coastwise species and extends from Boca de Camarioca, east of Matanzas, west to Boca de Jaruco, breaking up into four subspecies.

KEY TO THE SUBSPECIES OF CHONDROPOMA (CHONDROPOMA) OBESUM

Diameter of shell more than $9 \mathrm{~mm}$.

Shell pale orange. obesum

Shell dark orange subobesum Diameter of shell less than $7.5 \mathrm{~mm}$.

Shell gray palmasolense

Shell pale orange. hershei

CHONDROPOMA (CHONDROPOMA) OBESUM PALMASOLENSE, new subspecies

Plate 32, Figure 10

This race occupies the region about Palmasola near Boca de Camarioca, which lies halfway between Matanzas and Cardinas. Shell gray and much smaller and more cylindrical when truncated than the others. In this respect it resembles $C$. $(C$.) obesum hershei, differing from this, however, in coloration.

The type, U.S.N.M. no. 468971 , has 4 whorls remaining and measures: Length, $12.7 \mathrm{~mm}$; greater diameter, $7.4 \mathrm{~mm}$; lesser diameter, $6.2 \mathrm{~mm}$.

\section{CHONDROPOMA (CHONDROPOMA) OBESUM SUBOBESUM, new subspecies}

\section{Plate 32, Figure 9}

This race occupies the shoreline west of Matanzas but centers about Punta de Sabanilla. It differs from $C$. $(C$.) obesum abesum in being much darker orange and a little finer sculptured. 
The type, U.S.N.M. no. 468970, comes from Punta de Sabanilla and has a little less than 4 whorls remaining; it measures: Length, $14.3 \mathrm{~mm}$; greater diameter, $9.0 \mathrm{~mm}$; lesser diameter, $7.8 \mathrm{~mm}$.

CHONDROPOMA (CHONDROPOMA) OBESUM HERSHEI, new subspecies

Plate 32, Figure 8

This subspecies we have seen from Santa Cruz del Norte, Boca de Jaruco, and Boca de Canasi. It is a small pale-orange race and at times has a subperipheral brown band; in size it is even a little smaller than $C$. $(C$.) obesum palmasolense, from which the difference in color will at once distinguish it.

The type, U.S.N.M. no. 493173, comes from Santa Cruz del Norte. It has 4 whorls remaining and measures: Length, $11.0 \mathrm{~mm}$; greater diameter, $6.6 \mathrm{~mm}$; lesser diameter, $5.5 \mathrm{~mm}$.

\section{CHONDROPOMA (CHONDROPOMA) OBESUM OBESUM (Menke)}

Plate 32, Figure 11

1830. Truncatella obesa Menke, Synopsis methodica molluscorum . . ., ed. $2_{\text {r }}$ p. 137.

This race occupies the shoreline immediately east of Matanzas Bay and extends to the Canimar River. It approaches most nearly $C$. $(C$.) obesum subobesum but is readily distinguished from that by its much paler color.

The specimen figured, U.S.N.M. no. 493162, has a little more than 3 whorls remaining and measures: Length, $13.7 \mathrm{~mm}$; greater diameter, $9.1 \mathrm{~mm}$; lesser diameter, $7.3 \mathrm{~mm}$.

A series of 68 specimens give the following summary measurements :

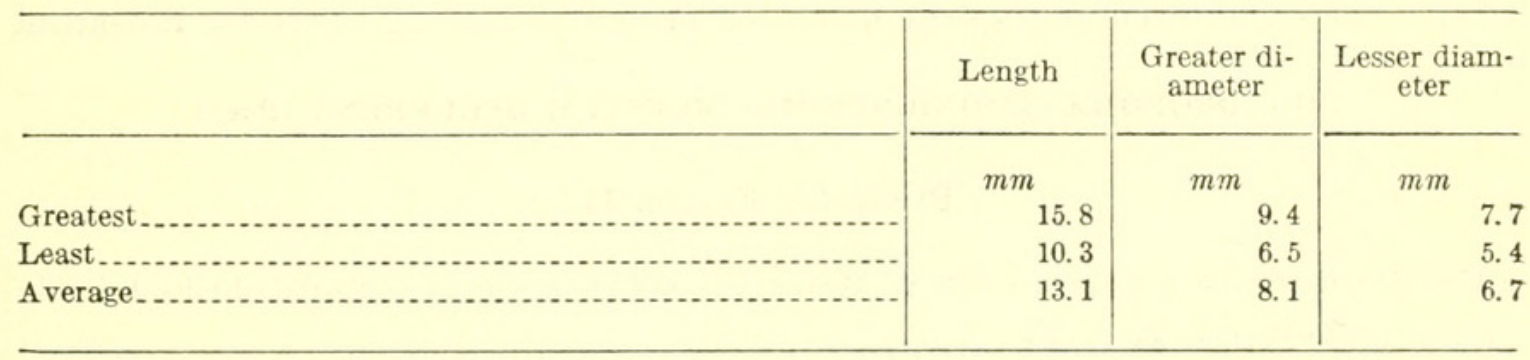

CHONDROPOMA (CHONDROPOMA) MOESTUM (Shuttleworth) Pfeiffer

Truncated shell ovate, rather thin, varying in color from isabeliine to pale horn-color, unicolor or marked with interrupted spiral bands of brown. The elements composing these are frequently also arranged in axial series. In the typical race the shell is unicolor, with bluish lead color, veinlike axial streaks. Nuclear whorls 2, darker than the postnuclear turns, forming a rather pointed apex, having the whorls inflated and strongly rounded. The postnuclear whorls 
are marked by rather prominent spiral cords, which increase in nt:mber by intercalation as the shell increases in size. On the early whorls there are also rather conspicuous, quite regular and regularly disposed, slightly retractively slanting, axial threads. These become enfeebled and in some of the races practically obsolete on the last turn. The summit of the whorls is rendered feebly denticulated by the axial markings. Suture well constricted; periphery inflated, strongly rounded. Base inflated, strongly rounded, openly umbilicated and marked with the same sculpture that characterizes the spire. This, however, becomes enfeebled on the umbilical wall. Aperture broadly ovate. Peristome simple, except at the slight auricle at the posterior angle where there is an indication of doubling. Operculum paucispiral with the nucleus halfway between marginal and central, covered with a thin deposit of calcareous granules.

Of the animal of $C$. $(C$.$) moestum moralesi, Bartsch took the fol-$ lowing color notes from specimens collected at the type locality of that race, July 15,1928 :

Animal flesh-color, with a pinkish tinge; forehead with numerons grayish spots, which are larger than usual; snout darker than forehead except at edge, which is devoid of spots. Tentacles with orange flesh-colored basal ring and brown tip. Sides of body ashy; foot ashy flesh-color, with brownish tinge medially deeply cleft. Motion of two sides alternate.

This species occupies the coastal region and adjacent hills immediately west of Matanzas Bay.

KEY TO THE SUBSPECIES OF CHONDROPOMA (CHONDROPOMA) MOESTUM

Shell with interrupted spiral bands of brown.

Length of decollated shell more than $16 \mathrm{~mm}$ decurrens

Length of decollated shell less than $13 \mathrm{~mm}$ moralesi Shell without interrupted spiral bands of brown moestum

\section{CHONDROPOMA (CHONDROPOMA) MOESTUM DECURRENS (Poey)}

\section{Plate 31, Figure 11}

1858. Cyclostoma decurrens PoEx, Memorias sobre historia natural de la Isla de Cuba, vol. 2, p. 23.

Poey, in his usual lucid way, gives a splendid characterization of this race, which has been confused with typical $C$. $(C$.) moestum moestum owing in large part, we believe, to mixed collectings. The shells that occupy the region about Punta Sabanilla are typical $C$. (C.) $m$. moestum, while the present race occupies the region about the Sinclair Oil Co.'s tanks at Dubroc, immediately south of Punta Sabanilla. The shells of this race are thinner, with more numerous, less strong, spiral cords and stronger axial elements amounting almost 
to threads, which are quite regularly spaced. Here, too, we have interrupted brown spiral bands.

The specimen figured, U.S.N.M. no. 499616, has almost 4 whorls remaining and measures: Length, $17.4 \mathrm{~mm}$; greater diameter, 12.2 $\mathrm{mm}$; lesser diameter, $10.1 \mathrm{~mm}$.

\section{CHONDROPOMA (CHONDROPOMA) MOESTUM MORALESI, new subspecies}

\section{Plate 31, Figure 8}

This subspecies occupies the La Cumbre ridge, which trends northwest of Matanzas harbor a couple of miles inland. It is a small race having interrupted spiral zones of brown, the dots being usually also arranged in axial series (sometimes the brown markings are absent). Both the axial and spiral sculpture recall $C$. (C.) moestum decurrens, from which it is easily distinguished by its small size.

The type, U.S.N.M. no. 499615, comes from Finca Aurora, La Cumbre. It has 3.8 whorls remaining and measures: Length, 12.1 $\mathrm{mm}$; greater diameter, $8.2 \mathrm{~mm}$; lesser diameter, $6.4 \mathrm{~mm}$.

\section{CHONDROPOMA (CHONDROPOMA) MOESTUM MOESTUM (Shuttleworth) Pfeiffer}

Plate 31, Figure 12

1854. Chondropoma moestum (Shuttleworth) Pfeiffer, Malakozool. Blätter, vol. 3, p. 132.

This subspecific name we are restricting to the shells from Punta Sabanilla, which are large, of isabelline color, with axial streaks of bluish lead color. Here the axial threads between the rather strong spiral cords are almost absent on the last whorl.

The specimen figured, U.S.N.M. no. 493179, has almost 4 whorls remaining and measures: Length, $17.0 \mathrm{~mm}$; greater diameter, 12.6 $\mathrm{mm}$; lesser diameter, $10.1 \mathrm{~mm}$.

\section{CHONDROPOMA (CHONDROPOMA) GARCIANUM Torre}

Plate 31, Figure 9

1913. Chondropoma garcianum Torke, Nautilus, vol. 27, p. 37 , pl. 3 , figs. $2,3$.

Truncated shell broadly ovate, flesh-color. Nuclear whorls decollated in all our specimens. Postnuclear whorls inflated, strongly rounded, and marked by slender threadlike riblets, which become slightly thickened, flattened, and expanded at the angle of the summit. The spiral sculpture consists of rather strong threads, which are considerably farther apart than the axial riblets. The axial riblets and spiral threads enclose slender oblong fenestrations, while their long axis coincides with the axial sculpture. The junctions of the axial riblets and spiral cords form slender nodules on the early 
turns but hardly so on the last. Suture narrowly but deeply channeled. Periphery of the last whorl strongly inflated, well rounded. Base short, inflated, well rounded, openly umbilicated, marked by the continuations of the axial riblets and spiral threads equaling those on the spire in strength. Those within the umbilicus are a trifle weaker and a little more closely spaced than those on the outside. Last whorl not solute, or only a trifle so. Aperture broadly oval; peristome double at the posterior angle; there is also a faint indication of an outer peristome on the inner lip; on the outer and basal lip the peristome seems simple. Operculum thin, corneous, paucispiral, with submarginal nucleus, the outside covered with a thin deposit of fine calcareous granules.

Three specimens before us come from Palma Sola, Matanzas Province.

The specimen described and figured, U.S.N.M. no. 493185, has a little more than 4 whorls and measures: Length, $15.3 \mathrm{~mm}$; greater diameter, $10.6 \mathrm{~mm}$; lesser diameter, $9.0 \mathrm{~mm}$.

\section{CHONDROPOMA (CHONDROPOMA) JAULENSE, new species}

Plate 30, Figure 11

Shell elongate-conic, varying from horn-color to pale brown, the early whorls usually much darker than the later turns. The latter are usually marked by axial zones of brown, which are somewhat wavy and suggest confluent elements of interrupted spiral bands. Nuclear whorls unknown. The postnuclear whorls are well rounded and marked by rather closely spaced spiral cords, which are almost as broad as the spaces that separate them, and feeble axial riblets, the latter most conspicuous at the summit, which they mark as fine white denticles. Suture moderately constricted; periphery well rounded. Base rather long, well rounded, and marked like the spire, openly umbilicated. The sculpture on the umbilical wall is a little less strong than on the rest of the base. The last whorl is slightly solute. Peristome simple on the outer lip, with a mere line of separation on the parietal wall and double on the inner lip.

This species was collected by Wright at Punta de Jaula.

The type, U.S.N.M. no. 499617, has 4 whorls remaining and measures: Lengths, $15.8 \mathrm{~mm}$; greater diameter, $9.0 \mathrm{~mm}$; lesser diameter, $7.5 \mathrm{~mm}$.

CHONDROPOMA (CHONDROPOMA) ANTONENSE, new species

Plate 31 , Figure 10

Shell elongate-ovate, stout, nuclear whorls decollated in all our specimens. The truncated end dark chestnut-brown, the succeeding 
turns very pale brown, the rest horn-color, unicolor or marked with interrupted spiral bands of brown. These bands when present are usually more strongly developed on the early turns than on the later, and are present on both spire and base. The interior of aperture pale buff; peristome yellowish horn-color. The whorls are strongly rounded, narrowly shouldered at the summit, which is rendered feebly crenulated by the occasional thickening of a rib. The axial sculpture consists of very distantly spaced, feeble threads, the rest being reduced to mere indications of feeble nodules at the summit and incremental lines. The spiral sculpture consists of rather strong cords, which are separated by spaces two to four times as wide as the cords. Near the base and on the base the incremental lines become a little stronger and slightly reticulate the spaces between the spiral cords. Suture narrowly channeled. Periphery inflated, very strongly rounded. Base inflated, well rounded, narrowly openly umbilicated, marked by the same type of sculpture as that which characterizes the spire, except in the umbilicus, where the spiral threads become intensified. Aperture ovate; peristome double, the outer narrowly expanded and reflected and rather thickened, adnate to the preceding turn on the parietal wall, the inner also expanded and reflected and projecting a little above the outer. Operculum thin, horny, paucispiral, with the nucleus almost submarginal, covered on the outside with a moderately thick, rather coarsely granular calcareous deposit.

The type, U.S.N.M. no. 493187, was collected on the Tomas Barrera Expedition at Cape San Antonio. It has a little over 3 whorls and measures: Length, $18.7 \mathrm{~mm}$; greater diameter, $12.2 \mathrm{~mm}$; lesser diameter, $10.4 \mathrm{~mm}$.

\section{CHONDROPOMA (CHONDROPOMA) MARGINALBUM (Gundlach) Pfeiffer}

Truncated shell elongate-ovate, pale brown, with faint interrupted spiral bands of brown; peristome white, interior of aperture pale brown. Nuclear whorls almost 2, inflated, strongly rounded, forming a somewhat truncated apex, the first smooth, the last showing the beginning of the postnuclear sculpture. Postnuclear whorls somewhat inflated, marked by strong, closely spaced, slightly retractively slanting axial riblets which crenulate the narrow summit of the whorls. The spiral sculpture consists of spiral cords which are considerably stronger than the axial riblets, the junction of the axial riblets and spiral cords form elongated nodules, which have their long axis parallel with the axial sculpture. Suture narrowly channeled. Periphery well rounded. Base moderately long, inflated, well rounded, narrowly openly umbilicated, marked by the continuation of the axial riblets and spiral threads with several fine spiral threads on the umbilical wall. Aperture oval; peristome double, 
the outer expanded and reflected, forming a conspicuous auricle at the posterior angle and adnate to the preceding turn on the parietal wall; the inner slightly exserted above the outer and also slightly reflected. Operculum thin, corneous, paucispiral, with submarginal nucleus, the outside covered with a thin deposit of fine calcareous granules.

This species appears to range from the mouth of Yateras River in Oriente, west through the Guantanamo Bay shorelines. We are recognizing three subspecies.

KEY TO THE SUBSPECIES OF CHONDROPOMA (CHONDROPOMA) MARGINALBUM

Denticles at the summit narrow and closely crowded marginalbum

Denticles at the summit not narrow or closely crowded.

Sculpture coarse guantanamense

Sculpture not coarse subguantanamense

CHONDROPOMA (CHONDROPOMA) MARGINABLUM MARGINABLUM (Gundlach) Pfeiffer Plate 31, Figure 2

1859. Cyclostoma marginalbum (Gundlach) Pfeiffer, Malakozool. Blätter, vol. 6 , pp. 75,76 .

This is the rose-colored race in which the axial riblets terminate as slender narrow, closely spaced denticles at the summit. The axial riblets are less strongly expressed and narrower than in the other two races. It comes from Caimanera.

The specimen figured, U.S.N.M. no. 493190, has about 4 whorls remaining and measures: Length, $18.0 \mathrm{~mm}$; greater diameter, 9.9 $\mathrm{mm}$; lesser diameter, $8.2 \mathrm{~mm}$.

CHONDROPOMA (CHONDROPOMA) MARGINALBUM GUANTANAMENSE, new subspecies

Plate 31, Figure 1

This race occupies the lowland point on the west side of the entrance to Guantanamo Bay. It is a small race with very close sculpture, comparatively speaking, and with strong denticulations at the summit.

The type, U.S.N.M. no. 367784 , has 3.3 whorls remaining and measures: Length, $14.0 \mathrm{~mm}$; greater diameter, $8.2 \mathrm{~mm}$; lesser diameter, $7.0 \mathrm{~mm}$.

\section{CHONDROPOMA (CHONDROPOMA) MARGINALBUM SUBGUANTANAMENSE, new subspecies}

Plate 31, Figure 3

This is a small race that appears to extend over the shoreline of the eastern portion of Guantanamo Bay, being found on the various 
digitations about the Naval Station. It is much smaller than the typical form and has even stronger, sharper denticulations at the summit than $C$. $(C$.) marginalbum guantanamense. It varies considerably in color from the typical rose-colored forms to ashy gray.

The type, U.S.N.M. no. 493198, comes from the hill at the officers' quarters at the Naval Station. It has 4 whorls remaining and measures: Length, $15.2 \mathrm{~mm}$; greater diameter, $8.0 \mathrm{~mm}$; lesser diameter, $7.0 \mathrm{~mm}$.

\section{CHONDROPOMA (CHONDROPOMA) OXYTREMUM (Gundlach) Pfeiffer}

\section{Plate 32, Fjgure 4}

1860. Cyclostoma (Chondropoma) oxytremum (Gundlach) Pfeiffer, Malakozool. Blätter, vol. 7, pp. 29-30.

Truncated shell elongate-ovate, buff with very faint interrupted spiral bands of brown. The dots composing these bands are usually arranged in both axial and spiral series. The whorls remaining are somewhat inflated, well rounded, narrowly shouldered at the summit, marked by threadlike, retractively slanting axial riblets, which are strongly developed at the summit, which they render conspicuously crenulate. The spiral sculpture consists of low, rounded threads, which are a little broader than the axial riblets. Of these, 12 are present on the last whorl between the summit and suture. The junctions of the axial riblets and the spiral threads form slender elongate nodules, which have their long axis parallel with the axial sculpture. The spaces enclosed between them are not conspicuously pitted. Suture narrowly channeled. Periphery well rounded. Base moderately long, slightly inflated, well rounded, marked by the continuations of the axial ribs and spiral threads, the latter a little weaker than those on the spire; the nodulation therefore also becomes somewhat weaker. There are two slender spiral threads within the narrow umbilicus. Aperture broadly oval; peristome simple, slightly expanded. The parietal lip is adnate to the preceding turn. Operculum thin, corneous, paucispiral, with submarginal nucleus, the outside covered with a thin deposit of fine calcareous granules.

The specimen described and figured, U.S.N.M. no. 493283, is the smallest of the lot of four obtained by Dr. Torre from Gundlach but is the most perfect. It was collected at Gibara. It has 3.5 whorls and measures: Length, $10.1 \mathrm{~mm}$; greater diameter, $6.0 \mathrm{~mm}$; lesser diameter, $5.5 \mathrm{~mm}$.

Of the animal of this species Gundlach says, loc. sit. "On stones in the neighborhood of Gibara. Animal whitish with a roseate sheen particularly upon the head. Foot with white spots, snout with blackish dots. Tentacles ochre colored with darker or greyish tip. The 
same color characterizes the base of the tentacles." The largest specimen has 3.5 whorls remaining and measures: Length, $12.3 \mathrm{~mm}$; greater diameter, $7.2 \mathrm{~mm}$; lesser diameter, $5.8 \mathrm{~mm}$.

\section{CHONDROPOMA (CHONDROPOMA) APPENDICULATUM, new species}

Shell when perfect elongate-ovate, when truncated ovate, varying in ground color from flesh-color to pale buff, marked with interrupted spiral bands of brown whose elements are also arranged in axial series. Nuclear whorls 2, forming a subcylindric apex, strongly inflated and rounded, smooth except the last portion of the last turn, which shows the beginning of the postnuclear sculpture. Postnuclear whorls narrowly shouldered at the summit, marked on the early turns by very numerous, closely spaced, hairlike, retractively slanting riblets, which become broader as the shell advances in growth but are never very strongly pronounced. Several of them, however, may fuse at the summit, or they may singly expand into conspicuous white denticles. The spiral sculpture consists of low, poorly developed cords, which are not so wide as the spaces that separate them. The junctions of the axial ribs and spiral cords produce feeble nodules. The whole sculpture of the spire presents an obsolete effect. Periphery well rounded. Base rather long, well rounded and marked like the spire. The umbilical wall is also marked by spiral threads and the feeble continuation of the axial ribs. Aperture broadly ovate; peristome double, the outer and inner quite indistinct on the basal and outer lip, but separated by an impressed line on the inner lip and parietal wall. The two form a conspicuous auricle at the posterior angle. Operculum thin, paucispiral, with submarginal nucleus covered with a thin deposit of calcareous granules.

This species is found about Gibara, Oriente Province, where two races are present.

KEY TO THE SUBSPECIES OF CHONDROPOMA (CHONDROPOMA) APPENDICULATUM

Spiral threads of last whorl 14 subappendiculatum Spiral threads of last whorl 17 appendiculatum

\section{CHONDROPOMA (CHONDROPOMA) APPENDICULATUM APPENDICULATUM, new subspecies}

\section{Plate 35, Figure 7}

This race, which was collected by Gonzales near Gibara, is the larger of the two races and has the sculpture much less strongly developed than the smaller race. It is also somewhat paler, with the interrupted spiral lines more conspicuous.

The type, U.S.N.M. no. 468978 , has 3.3 whorls and measures: Length, $16.4 \mathrm{~mm}$; greater diameter, $10.1 \mathrm{~mm}$; lesser diameter, $7.8 \mathrm{~mm}$. 


\title{
CHONDROPOMA (CHONDROPOMA) APPENDICULATUM SUBAPPENDICULATUM, new subspecies
}

Plate 35, Figure 8

This subspecies was collected by Allen about Gibara, without definite locality. It is smaller and darker colored than the typical race and has stronger sculpture.

The type, U.S.N.M. no. 468979, has 5.5 whorls remaining and measures: Length, $14.8 \mathrm{~mm}$; greater diameter, $7.8 \mathrm{~mm}$; lesser diameter, $6.7 \mathrm{~mm}$.

\section{CHONDROPOMA (CHONDROPOMA) LAETUM (Gutierrez) Poey}

\author{
Plate 35, Figure 2
}

1858. Cyclostoma lactum (GuTierRez) PoEY, Memorias sobre historia natural de la Isla de Cuba, pp. 33-34, pl. 4, fig. 1.

Truncated shell elongate-ovate. Early whorls decollated in all our specimens. Those remaining flesh-color, with interrupted spiral bands of pale brown. The dots composing these bands are arranged in both axial and spiral series. The whorls are inflated, narrowly shouldered, the shoulder marked by slender, rather regularly disposed denticles. The rest of the whorls are marked by retractively slanting axial threads, which are a little stronger on the early turns than on the rest. The spiral sculpture consists of rather distantly spaced, conspicuous, slender cords, of which 8 are present on the first of the remaining turns, 11 on the second and 12 on the last between the summit and suture. The junctions of the axial threads and spiral cords form slender nodules, which are materially reduced on the last turn, which bears a mere indication of them. Suture narrowly channeled. Periphery of the last whorl inflated, well rounded. Base short, inflated, well rounded, and marked by spiral cords of the same strength and spacing as those on the posterior half of the whorl. Within the umbilicus, however, they become less conspicuous. Aperture large, very oblique, broadly oval, rather strongly auriculated at the posterior angle; peristome double, the outer and inner coextensive on the outer lip, and but slightly differentiated at the posterior angle, on the parietal wall and on the inner lip.

The specimen described and figured, U.S.N.M. no. 493287, was collected by Dr. de la Torre at Gibara, Oriente Province. It has a little more than 3 whorls remaining and measures: Length, $12.0 \mathrm{~mm}$; greater diameter, $6.9 \mathrm{~mm}$; lesser diameter, $6.0 \mathrm{~mm}$.

\section{CHONDROPOMA (CHONDROPOMA) EDOUARDI Aguayo}

Shell of medium size, when truncated elongate-ovate, buff with interrupted spiral bands of brown. The elements composing these 
bands are also arranged in axial series. They are present on both spire and base. Nuclear whorls decollated; postnuclear whorls well rounded, narrowly shouldered at the summit, and crossed by numerous, somewhat wavy, slender axial riblets, which are about as wide as the spaces that separate them. These riblets render the summit of the whorls very finely serrulated. Suture very narrowly channeled; periphery inflated, strongly rounded. Base moderately long, openly umbilicate, marked like the spire. The umbilical wall, however, and the region adjacent to it are marked by stronger spiral threads. Aperture ovate, auriculated posteriorly. Peristome simple, slightly expanded and reflected. The last turn is solute for about one-tenth of a whorl. Operculum thin, corneous, paucispiral, with submarginal nucleus.

We are recognizing two subspecies.

KEY TO THE SUBSPECIES OF CHONDROPOMA (CHONDROPOMA) EDOUARDI

Junctions of the axial and spiral threads forming sharp cusps_-_-_- asperulum Junctions of the axial and spiral threads not forming sharp cusps_-.-- edouardi

\section{CHONDROPOMA (CHONDROPOMA) EDOUARDI EDOUARDI Aguayo}

\section{Plate 35, Figure 1}

1934. Chondropoma edouardi Aguayo, Mem. Soc. Poey, vol. 8, pp. 90-91, fig. 1.

This race, which was described by Aguayo from Loma de Canada de Jagüeyes, Holguin, differs from $C$. $(C$.) edouardi asperulum in the junctions of the axial riblets and spiral threads forming only feeble denticulations.

The specimen described and figured, U.S.N.M. no. 425501, which was received from Aguayo, has almost 4 whorls remaining and measures: Length, $14.1 \mathrm{~mm}$; greater diameter, $8.4 \mathrm{~mm}$; lesser diameter, $6.8 \mathrm{~mm}$.

\section{CHONDROPOMA (CHONDROPOMA) EDOUARDI ASPERULUM AgUayo}

Plate 35, Figure 3

1934. Chondropoma laetum asperulum Aguayo, Mem. Soc. Poey, vol. 8, pp. 8990 , fig. 2 .

This subspecies, also collected by Aguayo, comes from the Cerro Colorado near Gibara. It is distinguished from $C$. $(C$.) edouardi edouardi by having the junctions of the axial riblets and spiral threads much more strongly cusped; hence the name asperulum.

The specimen described and figured, U.S.N.M. no. 425503, received from Aguayo, has almost 4 whorls remaining and measures: Length $14.9 \mathrm{~mm}$; greater diameter, $9.2 \mathrm{~mm}$; lesser diameter, $7.0 \mathrm{~mm}$. 


\section{CHONDROPOMODES, new subgenus}

In this subgenus the shell is of ovate shape. The axial sculpture consists of exceedingly slender, rather closely spaced, sublamellar riblets, which are rendered sinuate by the slender spiral threads, the combination producing a vertebrated aspect. These riblets are gathered into tufts at the summit as in Chondropomorus.

Type: Chrondropoma (Chrondropomodes) santaluciense, new species.

\section{KEY TO THE SPECIES OF SUBGENUS CHONDROPOMODES}

Outer peristome broadly expanded ernesti Outer peristome not broadly expanded santaluciense

\section{CHONDROPOMA (CHONDROPOMODES) SANTALUCIENSE, new species}

\section{Plate 35, Figure 5}

Shell elongate-ovate, when truncated ovate, pale buff with interrupted spiral bands of brown. The dots composing these are very distantly spaced and arranged also in axial series. On the inner lip they are present, forming more or less confluent lines. Nuclear whorls a little more than 2, well rounded, smooth; postnuclear whorls well rounded, narrowly shouldered at the summit and marked by slender, closely spaced, sublamellar axial riblets and feeble spiral threads, which form, at the junction with the riblets, fine rounded tubercles and give to the riblets a somewhat vertebrated appearance. These riblets become fused at the summit of the whorls, where they form firm sharp white denticles. Suture channeled. Periphery of the last whorl well rounded. Base short, well rounded, and marked like the spire but with the spiral threads becoming a little stronger toward the open umbilicus whose parietal wall is marked by still stronger spiral threads and the continuation of the axial riblets. Aperture very broadly ovate; peristome double, forming a conspicuous auricle at the posterior angle. The outer peristome reflected and expanded; the inner also reflected and adnate to the outer, but not quite reaching its margin. On the auricles at the posterior angle there is a series of small lamellae indicating, evidently, a resting stage growth of these elements. The last whorl is slightly solute. Operculum thin, corneous, paucispiral, with marginal nucleus.

The type, U.S.N.M. no. 468980, comes from the Portales Camayuin, Arroyo Blanco, Santa Lucia, Oriente. It has 3.4 whorls remaining and measures: Length, $12.1 \mathrm{~mm}$; greater diameter, $9.5 \mathrm{~mm}$; lesser diameter, $7.3 \mathrm{~mm}$.

This species can be readily distinguished from Chondropoma (Chondropomodes) ernesti Pfeiffer by its having a much less expanded outer peristome. 


\section{CHONDROPOMA (CHONDROPOMODES) ERNESTI Pfeiffer}

Shell of medium size, flesh-color, with weak interrupted spiral bands of brown, which are present on spire and base. The spiral bands show as brown zones on the outer peristome; the plug at the decollated apex also shows through the substance of the shell as a dark-brown zone. Nuclear whorls a little more than 2, strongly rounded, smooth. Postnuclear whorls well rounded, narrowly shouldered at the summit, marked by very narrow, retractively curved axial riblets, which are rather closely spaced on the early whorls and much more so on the later. These riblets extend prominently to the summit, where they may fuse into tufts, which they render conspicuously crenulate. In addition to the axial riblets, the whorls are marked by spiral threads of about the same strength as the axial riblets; the junctions of these form slender nodules, while the spaces enclosed by them are rectangular, having their long axis parallel with the axial sculpture. Suture almost channeled. Periphery of the last whorl strongly rounded. Base inflated, strongly rounded, narrowly openly umbilicated, marked by the continuations of the axial riblets and the spiral threads, which are about as strong as those on the spire. Umbilicus marked by the continuations of the axial riblets and 8 spiral threads which are of almost equal strength. Aperture broadly oval; peristome double, the inner thickened at the edge and slightly reflected, the outer broadly expanded and reflected, not flatly but in a wavy oblique manner; the outer peristome forms a conspicuous auricle at the posterior angle; that of the parietal wall being appressed to the preceding turn, while that of the inner lip is reflected over and covers about two-thirds of the umbilicus; operculum paucispiral with subcentral nucleus.

Of this species Gundlach 12 states "Animal pale or whitish, only the head and neck somewhat brownish on account of the thicker mass of flesh. The head and neck are somewhat reddish within. Head and snout with dark markings which form almost regular interrupted lines. Tentacles gray, especially so at their tip. Eye ring whitish. The first whorl of the shell lets the animal shine through greenish, which is due to the color of the intestines. This species also suspends itself with a mucous thread when at rest."

We are recognizing two subspecies.

KEY TO THE SUBSPECIES OF CHONDROPOMA (CHONDROPOMODES) ERNESTI

Axial ribs distantly spaced clenchi

Axial ribs not distantly spaced ernesti

12 Malakozool. Blätter, vol. 9, p. 5, 1862. 


\title{
CHONDROPOMA (CHONDROPOMODES) ERNESTI ERNESTI Pfeiffer
}

\author{
Plate 35, Figure 4
}

1862. Chondropoma ernesti Pfeiffer Malakozool. Blätter, vol. 9, p. 5.

The typical subspecies was collected by Jeanneret at Seboruco, south of Mayari.

The specimen that we have figured, U.S.N.M. no. 367804, is one received by Dr. de la Torre from Jeanneret. It has a little more than 4 whorls remaining and measures: Length, $14.4 \mathrm{~mm}$; greater diameter, $8.9 \mathrm{~mm}$; lesser diameter, $7.0 \mathrm{~mm}$.

It is easily distinguished from $C$. $(C$.) ernesti clenchi by having the axial riblets and spiral threads more closely spaced.

\section{CHONDROPOMA (CHONDROPOMODES) ERNESTI CLENCHI Aguayo}

\section{Plate 35, Figure 6}

1932. Chondropoma ernesti clenchi Aguayo, Occ. Pap. Boston Soc. Nat. Hist., vol. 8 , p. 33 , pl. 3 , fig. $d$.

This subspecies was collected by Aguayo at Las Cuevas, Holguin, Oriente. It differs from the typical $C$. $(C$.) ernesti ernesti in being more inflated, that is, more broadly ovate, and in having both the axial and spiral sculpture more distantly spaced and the outer peristome more broadly expanded.

The specimen described and figured is a holotype and is located in the Museum of Comparative Zoölogy at Cambridge, Mass., where it is listed as no. 47999 .

\section{Subgenus Chondropomorus Henderson and Bartsch}

1920. Chondropomorus Henderson and Bartsch, Proc. U. S. Nat. Mus., vol. 58, p. 61.

Shell elongate-conic; marked by both axial and spiral threads, the axial threads being gathered into tufts at the summits of the whorls.

Type: Cyclostoma dentatum Say.

\section{KEY TO THE SPECIES OF SUBGENUS CHONDROPOMORUS}

Peristome simple.

Tufts at summit very regular revinctum

Tufts at summit irregular auberianum

Peristome double.

Outer peristome of inner lip broadly expanded.

Sculpture coarse and irregular delatreanum

Sculpture fine and regular neglectum

Outer peristome of inner lip not broadly expanded.

Peristome auriculate at posterior angle dilatatum

Peristome not auriculate at posterior angle canescens 


\section{CHONDROPOMA (CHONDROPOMORUS) REVINCTUM (Poey)}

1851. Cyclostoma revinctum PoEY, Memorias sobre historia natural de la Isla de Cuba, vol. 1, pp. 99, 106, pl. 5. figs. 24-27.

Shell elongate-conic, flesh-color, with various marblings, blotchings, spottings, and streakings of brown; but no matter what the superimposed color markings may be, there are always a number of interrupted spiral bands of dark brown, both on the spire and base, whose elements are arranged in both axial and spiral series. Aperture pale brown, showing the spiral bands within which extend over the peristome. Nuclear whorls 1.5, inflated, smooth, forming a truncated apex with the sutural line of the first whorl, chestnut-brown. Postnuclear whorls marked by retractively slanting axial riblets, which are low and only moderately strongly developed and which are gathered together into short and rather broad tufts at the summit at more or less regular intervals. The spiral sculpture consists of threads about as strong as the axial riblets, which are also not strongly elevated, the two forming a screenlike sculptural pattern. The junctions of the axial ribs and the spiral threads form scarcely perceptible nodules, while the spaces enclosed between them are squarish pits. Suture moderately constricted. Periphery with a feeble angulation. Base moderately long, well rounded, moderately broadly umbilicated, marked by the continuation of the axial riblets and spiral threads, which increase in size from the periphery toward the umbilicus, those within the umbilial wall being a little stronger than those immediately outside. Aperture broadly oval; peristome simple. Operculum paucispiral with submarginal nucleus, the outer surface covered with a fine thin granular calcareous deposit.

Of the animal of Chondropoma (Chondropomorus) revinctum revinctum Bartsch's field notes state:

"Animal pale gray with olivaceous tinge; dorsal part covered with ever so many tiny white dots. There is a pink area behind the tentacles. Tentacles faintly tinged with orange a little above the base, which is the general body color, the expanded tip dusky. Sides of body pale olivaceous. Sole of foot deeply cleft, a little more yellowish than the sides. Abundant on trees and in the rubbish at their base."

Of Chondropoma (Chondropomorus) revinctum biserranum he says :

"Animal smoky gray with greenish tinge, pinkish about the edges. Sole of foot a little paler, deeply cleft."

This species ranges from the coast at Punta San Juan de los Perros and Punta Alegre inland to the Dos Sierras near Zulueta, Santa Clara Province. We are recognizing two subspecies. 
KEY TO THE SUBSPECIES OF CHONDROPOMA (CHONDROPOMORUS) REVINCTUM

Shell moderately slender and of light color revinctum

Shell moderately stout and of darker color biserranum

CHONDROPOMA (CHONDROPOMORUS) REVINCTUM BISERRANUM, new subspecies

\section{Plate 33, Figure 6}

This subspecies, which comes from the mogotes of the Dos Sierras a little east of Zulueta, Santa Clara Province, differs from the typical form in being much darker, the interrupted spiral bands, particularly those near the suture, being spread out into blotches almost forming fulgurations. The whorls are also more inflated and the denticles are more pronounced.

The type, U.S.N.M. no. 499681, was collected by Bartsch on the mogote east of the gap of the Dos Sierras. It is a perfect specimen of 7.5 whorls and measures: Length, $16.2 \mathrm{~mm}$; greater diameter, 7.8 $\mathrm{mm}$; lesser diameter, $6.2 \mathrm{~mm}$.

\section{CHONDROPOMA (CHONDROPOMORUS) REVINCTUM REVINCTUM (Poey)}

\section{Plate 33, Figure 4}

1851. Cyclostoma revinctum PoEY, Memorias sobre historia natural de la Isla de Cuba, vol. 1, pp. 99, 106, pl. 5, figs. 24-27.

This race was first described from Punta San Juan de los Perros, Camaguey Province. Bartsch has also collected it on the paradones about Punta Alegre. This race is paler than the next and a little slenderer, with the whorls a little less convex and the denticles less pronounced.

The specimen figured, U.S.N.M. no. 388761, comes from Punta de los Perros. It is a perfect specimen of 8 whorls and measures: Length, $16.7 \mathrm{~mm}$; greater diameter, $7.5 \mathrm{~mm}$; lesser diameter, $5.8 \mathrm{~mm}$.

\section{CHONDROPOMA (CHONDROPOMORUS) CANESCENS Pfeiffer}

Shell elongate-conic; the color pattern varies materially, sometimes even in the same locality, although as a rule there is a comparatively uniform aspect to it in the same locality. The shell may be fiesh-color, or flesh-color with a brownish tinge. In all shells, even those that are more or less unicolor on the later turns, the early whorls have at least an indication of usually four interrupted spiral bands of brown. These frequently are reduced to mere dots; but whether almost continuous or mere dots, their arrangement is in both axial and spiral series. Frequently there are cloudings to the ground color, and even more frequently there are axial bands of brown or dark brown comma-shaped areas pending from the summit, and other blotches below it; or the shell may be vermiculated, flammulated, or ful- 
gurated. There is usually a subperipheral dark spiral zone a little more pronounced than those on the spire. The rest of the base is marked like the spire. The inside of the aperture varies from fleshcolor to brown. In one race there is a dark reddish-brown band immediately within the outer lip on the inner peristome; the outer edge of the inner peristome is usually paler and shows the spiral bands of brown more or less conspicuously, depending upon the development of this element. Nuclear whorls 2, inflated, strongly rounded, forming a blunt apex. Suture with a conspicuous brown zone. Postnuclear whorls well rounded, marked by axial ribs which vary considerably in strength. At more or less regular intervals these riblets are gathered into tufts at the summit, which likewise vary in strength from broad coarse denticles to slender, short toothlike elements. The spiral scultpure is as variable as the axial, and usually varies with it; that is, when the axial sculpture is feeble, the spiral is likewise so; when the axial sculpture is strong, the spiral is likewise. Suture well constricted. Periphery well rounded. Base moderately long, well rounded, narrowly openly umbilicate, the widths of the umbilicus being rather constant for the race in question, marked by the continuation of the axial riblets and spiral threads. Aperture oval; peristome double; the outer of variable width, sometimes scarcely extending beyond the inner, at others rather conspicuously expanded. These characters appear to be constant in the different races. The outer peristome is more or less scalloped at the edge, and this scalloping varies in extent; in some races it extends over the major portion of the outer and basal lip, and even the anterior portion of the inner lip; while in others it may be restricted to the angle of the inner and basal lip; the outer peristome is a little more expanded as a rule at the posterior angle, but it does not form a conspicuous auricle at this place; the outer peristome may be fused with the preceding whorl at the parietal wall; it may be appressed to it or entirely free from it. In some of the races this character appears to be constant, while in others it varies from one extreme to another. The inner peristome is also expanded, but less so than the outer, and slightly reflected, usually a little broader on the outer lip than the inner or parietal. Operculum paucispiral with submarginal nucleus, the outer surface covered with a fine thin granular calcareous deposit.

Dr. de la Torre has examined Pfeiffer's type of this species in the British Museum and based the following notes thereon:

"A worn specimen without operculum, very elongate, nearly entire, partly calcined, but it is possible to see that it belonged to the orange or reddish colored variety. It measures: Length, $20.0 \mathrm{~mm}$; diameter, $7.0 \mathrm{~mm}$; aperture length, $5.0 \mathrm{~mm}$; diameter, $4.0 \mathrm{~mm}$. The label states that it was received from Cumings." 
Pfeiffer cites Gibara, Nuevitas, and Holguin. Of these three localities the specimens from Nuevitas satisfy Pfeiffer's description best. They also correspond with the type in size and color. We shall, therefore, consider the Nuevitas race the typical one.

The species ranges from Turiguano Island through the Cubitas Mountains eastward to Sagua de Tanamo, breaking up into a series of races described below.

\section{KEY TO THE SUBSPECIES OF CHONDROPOMA (CHONDROPOMORUS) CANESCENS}

Adult shell with a dark axial zone immediately within peristome

of outer lip alleni

Adult shell without a dark axial zone immediately within peristome

of outer lip.

Shell comparatively slender nipense

Shell not comparatively slender.

Truncated shell short and stout perplexum

Truncated shell rather long and less stout canescens

\section{CHONDROPOMA (CHONDROPOMORUS) CANESCENS CANESCENS Pfeiffer}

Plate 33, Figure 8

1851. Chondropoma canescens PfeIffer, Proc. Zool. Soc. London, 1851, p. 245. 1851. Cyclostoma confertum PoEY, Memorias sobre historia natural de la Isla de Cuba, vol. 1, pp. 99, 106, pl. 8, figs. 1-3.

This subspecies we restrict to the race occupying Nuevitas and the Cubitas Mountain region as well as the mogotes adjacent to these. The truncated shell is rather long, and the whorls are inflated. The sculpture is strong; the outer peristome is rather broadly expanded. It differs chiefly from $C$. $(C$. $)$ canescens perplexum in being more elongate.

The specimen figured, U.S.N.M. no. 355068, comes from Loma de Borje, Camaguey Province. It has 5.8 whorls remaining and measures: Length, $17.2 \mathrm{~mm}$; greater diameter, $8.5 \mathrm{~mm}$; lesser diameter, $6.8 \mathrm{~mm}$.

CHONDROPOMA (CHONDROPOMORUS) CANESCENS PERPLEXUM, new subspecies

Plate 33, Figure 7

This race occupies the region about Gibara and Holguin.

It most nearly resembles the typical race, $C$. $(C$.) canescens canescens but differs from it in the truncated shell being shorter and in being a little more heavily denticulated at the summit, with the outer peristome a little less strongly expanded.

The type, U.S.N.M. no. 355062, comes from Holguin. It has almost 5 whorls remaining and measures: Length, $14.2 \mathrm{~mm}$; greater diameter, $7.0 \mathrm{~mm}$; lesser diameter, $5.9 \mathrm{~mm}$. 
CHONDROPOMA (CHONDROPOMORUS) CANESCENS NIPENSE, new subspecies

Plate 33, Figure 9

This race comes from the region about Nipe Bay, Felton, Antilla and Cayo del Rey. It is readily distinguished from the rest in being much slenderer and with the whorls less inflated.

The type, U.S.N.M. no. 355085, comes from Felton. It has 5.8 whorls remaining and measures: Length, $15.1 \mathrm{~mm}$; greater diameter, $7.0 \mathrm{~mm}$; lesser diameter, $5.6 \mathrm{~mm}$.

\section{CHONDROPOMA (CHONDROPOMORUS) CANESCENS ALLENI, new subspecies}

\section{Plate 33, Figure 5}

This race comes from the region about Sagua de Tanamo. In many ways this shell resembles $C$. $(C$.) canescens perplexum, but the adult shells, however, are very readily distinguished from it by the dark chestnut-brown axial zone on the inside of the outer lip immediately within the peristome.

The type, U.S.N.M. no. 367774 , has 5.3 whorls remaining and measures: Length, $14.4 \mathrm{~mm}$; greater diameter, $6.8 \mathrm{~mm}$; lesser diameter, $5.7 \mathrm{~mm}$.

\section{CHONDROPOMA (CHONDROPOMORUS) NEGLECTUM (Gundlach) Pfeiffer}

Plate 34, Figure 5

1856. Cyclostoma neglectum PoEY, Memorias sobre historia natural de la Isla de Cuba, p. 4, nomen nudum.

1858. Cyclostoma neglectum (Gundlach) PFEIfFer, Malakozool. Blätter, vol. 5, pp. $46-47$.

1858. Chondropoma revinctum PFEIFFER, Monographia pneumonopomorum viventium, suppl. 1, p. 137.

Shell very elongate-conic, of horn-color ground color, with interrupted bands of brown having both an axial and spiral arrangement. The long axis of the dark streaks is parallel with the spiral sculpture. In addition to this, the ribs are flesh-color in irregular blotches. The inner peristome is pale brown at its outer margin, while the outer shows the dark spiral bands. There is also a very dark brown band encircling the top of the nuclear turns. Nuclear whorls 2, rather large, forming a blunt apex; the first 1.5 well rounded, smooth, the last half with fine axial threads. There is an oblique band of brown at the termination of the nuclear turns, marking a septum or place for disjunction. Postnuclear whorls almost inflated, strongly rounded, marked by threadlike, somewhat retractively curved, axial riblets, which at more or less irregular intervals become strengthened at the summit where several of them frequently fuse to form a toothlike projection, which is appressed to the preceding turn. In addition to the axial sculpture the whorls are marked by spiral threads, which 
are equal to the axial riblets in strength. The junction of these two elements forms slender nodules, while the spaces enclosed between them form squarish pits. Suture rendered conspicuously crenulated by the toothlike projection at the summit. Periphery well rounded. Base moderately long, well rounded, moderately, broadly umbilicate, marked by the continuation of the axial riblets and spiral threads, which are a little stronger than those on the spire. The umbilical wall is marked by five rather strong spiral cords as well as the feeble continuation of the axial riblets. Aperture oval; peristome double all around; outer peristome expanded obliquely all around, a trifle narrower on the columellar wall; inner peristome also expanded and reflected; at the posterior angle there is a slight auriculation, and here several lamellae are present between the inner and outer peristome. Operculum thin, paucispiral with the nucleus intermediate between subcentral and marginal, the major portion covered with a thin, finely granular deposit.

The specimen described and figured, U.S.N.M. no. 493256, is one received from Dr. de la Torre and collected by Cisneros at Cabo Cruz, Oriente Province. This has 7.6 whorls and measures: Length, 15.0 $\mathrm{mm}$; greater diameter, $6.8 \mathrm{~mm}$; lesser diameter, $5.4 \mathrm{~mm}$.

The species ranges along the south coast from Ojo de Agua to Manzanillo.

\section{CHONDROPOMA (CHONDROPOMORUS) DILATATUM (Gundlach) Pfeiffer}

Shell elongate-conic, with the ground color flesh-color or horn color, marked by interrupted spiral bands of brown, which vary from inconspicuous to very decided chestnut brown in color, and which also vary very materially in width; peristome whitish, rayed with brown; the interior of the aperture varies with the coloration of the outside; there is also a brown line following the suture on the apex of the shell. Nuclear whorls almost 2, well rounded, smooth except the last portion of the last turn, which shows the beginning of the postnuclear sculpture. Postnuclear whorls strongly rounded, marked by very slender, poorly developed, retractively slanting axial riblets; of these, at quite regular intervals, several become fused at the summit to form conspicuous denticles. The strength of these denticles varies materially in the different races. The spiral sculpture consists of quite closely spaced threads, which in some of the races are of about the same strength as the axial riblets, while in others they are weaker; the junctions of the axial riblets and the spiral threads scarcely form nodules, while the spaces enclosed between them are moderately well impressed pits. Suture well constricted. Periphery subangulate. Base short, well rounded, openly 
umbilicated, marked by the continuation of the axial riblets and the spiral threads equaling those of the spire on the last turn in strength and spacing; immediately within the umbilicus there are several stronger spiral threads. Aperture very broadly oval; peristome double, the outer slightly expanded and slightly reflected, denticulate at the junction of the inner and basal lip; the inner moderately exserted and also reflected and almost fused with the outer. Operculum very thin with the nucleus halfway between marginal and central, the inner half of the last whorl covered with a very thin coat of calcareous granules.

This species is confined to eastern Cuba where it breaks up into a number of subspecies here described.

Of the typical race Gundlach says: "On trees. Animal brownish white, on the head (between the antennae), and on the rump gray. Neck clay yellow; antennae bright brown with white apex. The region about the eye white."

KEY TO THE SUBSPECIES OF CHONDROPOMA (CHONDROPOMORUS) DILATATUM

Greater diameter more than $8.5 \mathrm{~mm}$ toroense Greater diameter less than $8.0 \mathrm{~mm}$.

Sculpture rather coarse pilotense

Sculpture fine.

Denticles at the summit fine and closely spaced.

Interrupted spiral bands of brown broad. bayatense Interrupted spiral bands of brown narrow dilatatum Denticles at summit not fine or closely spaced subdilatatum

\section{CHONDROPOMA (CHONDROPOMORUS) DILATATUM DILATATUM (Gundlach) Pfeiffer}

Plate 34, Figure 9

1859. Cyclostoma dilatatum (Gundlach) PfeIfFer, Malakazool. Blätter, vol. 6, p. 75 .

This race, which originally was collected by Gundlach along the River Yateras, by Wright at Monte Verde, and by Henderson and Bartsch on the shoulder of Monte Libano near the Guaso River, has the whorls moderately inflated and finely denticulated at the summit. The interrupted spiral bands are, comparatively speaking, narrow, the surface is blotched with white areas suggesting a watered silk aspect.

The specimen described and figured, U.S.N.M. no. 493258, is one of two collected by Gundlach at Yateras. It has 8.0 whorls remaining and measures: Length, $16.6 \mathrm{~mm}$; greater diameter, $7.6 \mathrm{~mm}$; lesser diameter, $6.1 \mathrm{~mm}$.

Of the subspecies here described it most nearly resembles $C$. (C.) dilatatum bayatense, from which it can be distinguished easily by its larger size and narrower interrupted spiral bands. 
CHONDROPOMA (CHONDROPOMORUS) DILATATUM TOROENSE, new subspecies

Plate 34, Figure 7

This race comes from San Felipe, Lechuza, Monte Toro. It is the largest of the known races and has the elements constituting the interrupted spiral bands so much widened that they almost fuse axially, forming conspicuous axial dark bands.

The type, U.S.N.M. no. 367766, has 5.6 whorls remaining and measures: Length, $16.8 \mathrm{~mm}$; greater diameter, $8.6 \mathrm{~mm}$; lesser diameter, $7.0 \mathrm{~mm}$.

CHONDROPOMA (CHONDROPOMORUS) DILATATUM BAYATENSE, new subspecies

Plate 34, Figure 6

This race was collected by Dr. Ramsden at Bayate, west of Monte Toro. It is a small race resembling in the character of the sculpture the typical $C$. $(C$.) dilatatum but differing from it in having the spiral bands, comparatively speaking, much broader, in which respect it stands about halfway between $C .(C$.) dilatatum dilatatum and C. (C.) d.toroense.

The type, U.S.N.M. no. 367768, has 5.5 whorls remaining and measures: Length, $11.9 \mathrm{~mm}$; greater diameter, $6.1 \mathrm{~mm}$; lesser diameter, $5.0 \mathrm{~mm}$.

CHONDROPOMA (CHONDROPOMORUS) DILATATUM PILOTENSE, new subspecies

Plate 34, Figure 4

This subspecies comes from Pilote, Arriba, Mayari. It differs from all the others by having both the axial and spiral sculpture much coarser and more netlike with the denticles at the summit much heavier.

The type, U.S.N.M. no. 367767 , is a complete specimen of seven whorls and measures: Length, $13.2 \mathrm{~mm}$; greater diameter, $6.4 \mathrm{~mm}$; lesser diameter, $5.5 \mathrm{~mm}$.

CHONDROPOMA (CHONDROPOMORUS) DILATATUM SUBDILATATUM, new subspecies

Plate 34, Figure 8

The type of this race comes from Guajenal, Sagua de Tanamo. We also have it from El Coco, Sagua de Tanamo.

It differs from typical $C$. $(C$.) dilatatum dilatatum, with which it agrees in size, in having both the axial and spiral sculpture coarser but not so coarse as in $C$. $(C$.) dilatatum pilotense. The denticles at the summit, too, stand about half way between these two forms, while the outer peristome is much more expanded than in any of the others. 
The type, U.S.N.M. no. 367764, has 6.0 whorls remaining and measures: Length, $16.1 \mathrm{~mm}$; greater diameter, $6.8 \mathrm{~mm}$; lesser diameter, $5.5 \mathrm{~mm}$.

\section{CHONDROPOMA (CHONDROPOMORUS) DELATREANUM (OrbignY)}

Shell elongate-conic; all our specimens truncated; ground color ranging from flesh-color to pale brown; darker brown spiral bands are present, which are usually interrupted and the elements constituting them are arranged in both axial and spiral series. At times, however, they are continuous, but even then there is more or less of an axial and spiral emphasis in the color pattern. At times the outer edge of the axial ribs is white, which forms, in addition to the color scheme mentioned above, a blotchy appearance. The peristome is rarely ever marked by strong alternating bands of dark and light; as a rule it is unicolor. Postnuclear whorls moderately strongly arched, marked by retractively slanting axial riblets, which are slightly sinuous and which are at irregular intervals gathered into tufts or strong denticles at the summit. In addition to this, spiral threads are present, which are a little wider than or as wide as the axial ribs. The junctions of the ribs and the spiral threads form slender nodules, while the spaces enclosed between them form more or less rectangular or squarish pits. Suture moderately constricted. Base moderately long, narrowly openly umbilicated, marked by the continuation of the axial ribs and spiral threads, the latter a little broader and more closely spaced than those on the spire. The umbilical wall is marked by rather conspicuous spiral threads. The last whorl is solute for a small fraction of a turn. Aperture oval; peristome double, both the inner and outer moderately expanded and reflected, the outer extends a little less beyond the inner on the columellar wall and forms a slight auricle at the posterior angle; the inner projects considerably above the outer. Operculum thin, with the nucleus midway between subcentral and marginal, covered with a fine, thin granular deposit.

The races of this species are distributed through Santa Clara Province.

KEY TO THE SUBSPECIES OF CHONDROPOMA (CHONDROPOMORUS) DELATREANUM

Length of decollated shell more than $13 \mathrm{~mm}$ santafeum

Length of decollated shell less than $12 \mathrm{~mm}$.

Last whorl conspicuously solute bonacheum

Last whorl not conspicuously solute delatreanum

CHONDROPOMA (CHONDROPOMORUS) DELATREANUM SANTAFEUM, new subspecies Plate 33, Figure 2

This race, which is larger than the others, comes from the region about Loma de Santa Fe, Santa Clara Province. The sculpture is 
much stronger than in the other races. The color markings on the peristome also extend more prominently over the outer lip.

The type, U.S.N.M. no. 493277, was collected by John B. Henderson at Loma de Santa Fe. It has a little more than 5 whorls remaining and measures: Length, $13.9 \mathrm{~mm}$; greater diameter, $6.1 \mathrm{~mm}$; lesser diameter, $5.2 \mathrm{~mm}$.

CHONDROPOMA (CHONDROPOMORUS) DELATREANUM BONACHEUM, new subspecies

Plate 33, Figure 1

This is the other small race that has the sculpture stronger than the typical $C .(C$.$) delatreanum delatreanum and the denticles at the$ summit stronger and more distantly spaced. The last whorl is also much more solute.

The type, U.S.N.M. no. 493279, comes from Loma de Bonachea, a limestone hill on the north side of the road leading from Santa Clara to Remedios, 5 or 6 miles from Santa Clara. It has 4 whorls remaining and measures: Length, $11.1 \mathrm{~mm}$; greater diameter, $5.8 \mathrm{~mm}$; lesser diameter, $4.5 \mathrm{~mm}$.

CHONDROPOMA (CHONDROPOMORUS) DELATREANUM DELATREANUM (Orbigny)

Plate 33, Figure 3

1841. Cyclostoma delatreana ORBIGNy, in Sagra's Histoire physique, politique et naturelle de l'Ile de Cuba, vol. 1, pp. 262-263.

1845. Cyclostoma dutertreana ORBIGNy, in Sagra's Histoire physique, politique et naturelle de l'Ile de Cuba, vol. 1, pl. 22, figs. 18-20.

This race occupies the region about Soledad and Trinidad, Santa Clara Province. It is one of the two small races with the sculpture less strongly developed than in the others. It usually has a somewhat oily appearance and the denticles average finer than in the other small race, $C$. $(C$.) delatreanum bonacheum, from which it also differs by having the last whorl less solute.

The specimen described and figured, U.S.N.M. no. 493267, comes from near Guanao, 5 miles east of Cienfuegos. It has a little more than 5 whorls remaining and measures: Length, $11.1 \mathrm{~mm}$; greater diameter, $5.4 \mathrm{~mm}$; lesser diameter, $4.2 \mathrm{~mm}$.

\section{CHONDROPOMA (CHONDROPOMORUS) AUBERIANUM (Orbigny)}

Shell elongate-conic, pale brown, marked by narrow elongated brown spots, which form almost continuous spiral bands. Nuclear whorls 2 , inflated, forming a truncated apex, the first very finely granulose, the last half of the last with fine indistinct axial threads. Postnuclear whorls well rounded, marked by well-elevated, retrac- 
tively slanting axial threads. A number of these threads are gathered together at the summit at more or less regular intervals into broad, large tufts or denticles. The spiral sculpture consists of threads a little stronger than the axial but much more distantly spaced. The junctions of the axial and spiral threads form feeble nodules, while the spaces enclosed between them form rectangular pits having their long axis parallel with the axial sculpture. Suture moderately constricted. Periphery of the last whorl well rounded. Base moderately long, well rounded, narrowly umbilicated, marked by the continuation of the axial ribs and spiral threads, the latter a trifle stronger than those on the spire. Several spiral threads are present on the parietal wall within the umbilicus. Last whorl slightly solute. Aperture broadly oval; slightly angulated at the posterior angle; peristome single, though in some of the specimens there is the merest indication of doubling at the posterior angle. This, however, may be altogether due to the denticles being well developed at that place at times. Operculum thin, paucispiral, with a thin, finely granular deposit on the outside. Nucleus submarginal.

Pfeiffer describes the animal as ashy gray. Eyes very distant, black, placed upon the white conic antennae. Foot very short posteriorly.

This is a lowland species that ranges from Matanzas Province west to Esperanza and southward to the south coast. $C$. $(C$.) auberianum has been confused with $C$. $(C$.) dentatum, which comes from the Florida Keys and which we consider a distinct species.

We are recognizing two subspecies.

KEY TO THE SUBSPECIES OF CHONDROPOMA (CHONDROPOMORUS) AUBERIANUM

Axial and spiral sculpture prominent_ auberianum

Axial and spiral sculpture not prominent mayense

\section{CHONDROPOMA (CHONDROPOMORUS) AUBERIANUM AUBERIANUM (Orbigny)}

Plate 34, Figures 1, 3

1839. Cyclostoma lineolatum Anton, Verzeichniss der Conchylien, p. 54; not Cyclostoma lineolatum Lamarck, Histoire naturelle des animaux sans vertébres, vol. 6 , pt. 2 , p. $147,1822$.

1839. Cyclostoma crenulatum PFEIFFER, Wiegmann's Archiv für Naturg., vol. 1, p. 356; not Cyclostoma crenulatum (Férussac) Potiez and Michaud, Galerie des mollusques . . Douai, vol. 1, p. 235, pl. 24, figs. 3, 4, 1838. 1842. Cyclostoma auberianum OrBIGNY, in Sagra's Histoire physique, politique et naturelle de l'Ile de Cuba, vol. 1, p. 260, pl. 22, figs. 12-14.

1850. Licina lunulatum MüLLER, in Mörch's Catalogus conchyliorum quae reliquit C. P. Kierulf, p. 8.

1876. Chondropoma cisnerosi Arango, Ann. Real Acad. Cienc. Habana, 1876, p. 1. 
This very widely distributed race is easily distinguished from $C$. (C.) auberianum mayense by its larger size and weaker sculpture. The unworn shells always have a shining semivarnished aspect, which is absent from both $C .(C$.$) auberianum mayense and C .(C$. dentatum.

The specimen figured, U.S.N.M. no. 493204, is one of four collected by Gundlach at Habana. It has 4 whorls remaining and measures: Length, $13.2 \mathrm{~mm}$; greater diameter, $6.5 \mathrm{~mm}$; lesser diameter, $5.6 \mathrm{~mm}$.

A summary of the measurements of 100 specimens from various localities yields the following data:

\begin{tabular}{|c|c|c|c|c|}
\hline & Number of whorls & Length & $\begin{array}{l}\text { Greater } \\
\text { diameter }\end{array}$ & $\begin{array}{c}\text { Lesser } \\
\text { diameter }\end{array}$ \\
\hline Greatest & 6.9 & ${ }_{15.8}$ & ${ }_{7.7}$ & $M m$ \\
\hline Least_....................................... & $4+($ tip broken) & 7. 2 & 4. 5 & 3. \\
\hline A verage.......................... & $4+($ tip broken $) .. . . .$. & 12. 2 & 6.2 & 5. \\
\hline
\end{tabular}

Chrondropoma cisnerosi Arango was based upon a pathologic specimen, the obsolete keeling of which was due to an injury.

CHONDROPOMA (CHONDROPOMORUS) AUBERIANUM MAYENSE, new subspecies

Plate 34, Figure 2

This race, which comes from the north coastal region east of Matanzas, is smaller than typical $C$. $(C$.) auberianum auberianum and has the sculpture much stronger and lacks the semivarnished aspect of that race. In strength of sculpture it resembles the Floridian $C$. $(C$.) dentatum Say but differs from that by having the axial riblets much less crowded.

The type, U.S.N.M. no. 134930, comes from Palma Sola east of Punta de Maya, that is, between Matanzas and Cardenas. It has 4.3 whorls remaining and measures: Length, $10.2 \mathrm{~mm}$; greater diameter, $5.2 \mathrm{~mm}$; lesser diameter, $4.4 \mathrm{~mm}$.

\section{ChONDROPOMISCA, new subgenus}

Small shells, varying from ovate to broadly ovate in outline, with the spiral threads a little stronger than the axial riblets, the junctions of the two forming sharply pointed cusps. The summit of the whorls is rendered finely denticulated by the axial riblets. Peristome double, the outer only moderately expanded.

Type: Cyclostoma (Chondropoma) rufopictum (Gundlach) Pfeiffer. 
Shell inflated, very broadly ovate.

Sculpture very coarse greenfieldi

Sculpture fine revocatum

Shell not inflated, not very broadly ovate.

Shell ovate.

Nodulations of whorls strong rufopictum

Nodulations of whorls not strong.

Nodulations very fine and regular.

Axial and spiral seulpture of equal strength solidulum

Axial and spiral sculpture not of equal strength.

Spiral sculpture stronger than axial

unilabiatum

Shell not ovate.

Shell elongate-ovate aguayoi

\section{CHONDROPOMA (CHONDROPOMISCA) RUFOPICTUM (Gundlach) Pfeiffer}

Plate 39, Figure 2

1860. Cyclostoma (Chondropoma) rufopictum (Gundlach) Pfeiffer, Malakozool. Blätter, vol. 7, pp. 30-31.

Shell small, ovate, the first postnuclear turn is dark brown on the posterior half, the rest, as well as the succeeding whorls, are fleshcolor, with spots of brown arranged in axial and spiral series. Postnuclear whorls well rounded but not inflated, narrowly shouldered at the summit, marked by rather strong, slightly retractively slanting, slender axial ribs, which are rather distantly spaced on all the turns, and five feeble spiral cords, which are obsolete on the first turn; the junctions of the spiral cords and the axial riblets form poorly developed nodules, an occasional one of which is thin and hollow. The axial riblets extend strongly to the shoulder at the summit, which they render crenulated. Suture almost channeled. Periphery obsoletely angulated. Base well rounded, rather openly umbilicated, the outer limit of the umbilicus marked by a strong spiral cord and two, a little less strong are present within the umbilicus. In addition to this, the base is marked by the continuation of the axial riblets. Aperture pyriform; peristome double, the inner slightly reflected and marked by alternate rays of pale brown and darker brown; the outer closely approximated to the inner all around except at the posterior angle where it is projected to form a slight ear. Here several lamellae are present, filling the gap between the two peristomes; the parietal wall is appressed to the preceding turn. Operculum paucispiral with subcentral nucleus, the outside covered with a thin deposit of fine granules.

Of this Gundlach states, loc. cit.: "On trees and shrubs at Baracoa. Animal pale or bright brownish. Black splotches or spots on the neck and are present in greater numbers on the anterior end of the 
head where they become confluent. White blotches are present on the sides of the body. Head red within; base of tentacles whitish rosered, the middle mennig-red with the tip thickened and gray."

The specimen described and figured, U.S.N.M. no. 354934, is one of two from the Redfield collection obtained from Poey and labeled as coming from Jacquecito, Baracoa. It has 4 whorls and measures: Length, $9.4 \mathrm{~mm}$; greater diameter, $6.1 \mathrm{~mm}$; lesser diameter, $5.0 \mathrm{~mm}$.

\section{CHONDROPOMA (CHONDROPOMISCA) UNILABIATUM (Gundlach) Pfeiffer}

Shell small, white, horn-color, yellow or orange. Nuclear whorls 2.5 , very inflated, strongly rounded, forming a blunt apex, smooth, excepting the last portion of the last whorl, which shows the beginning of the postnuclear sculpture. Postnuclear whorls well rounded, narrowly shouldered at the summit, marked by retractively slanting axial riblets, which are a little more closely crowded upon the last than the earlier turns. In addition to these riblets, the whorls are marked by slender spiral cords, which render their junctions with the axial riblets regularly, finely nodulose, while the spaces enclosed between them are somewhat curved, rectangular and narrow, having their long axis parallel with the axial sculpture. The angle at the summit of the whorls is rendered crenulated by the tubercles of the first spiral cord. Suture almost channeled. Periphery well rounded. Base very broad, somewhat inflated, well rounded, narrowly openly umbilicated, marked by almost equal and equally spaced spiral threads, which render the axial riblets which continue over the base, wavy; the outer limit of the umbilicus is marked by a strong spiral cord and a second a little less strong on the midspace of the umbilical wall; the umbilical wall is also marked by the continuations of the fine axial riblets. Aperture broadly oval; peristome expanded with a poor indication toward doubling at the posterior portion of the inner lip, rather broadly expanded and refiected; parietal wall appressed and fused to the preceding turn; operculum paucispiral with subcentral nucleus.

Of this Gundlach says, loc. cit.: "On cliffs at Baracoa. Animal gray; whitish dots form spots by their confluence on the sides of the foot, on the base of the tentacles and on the neck. Black marks or wavy confluent lines are present on the snout and in lesser numbers upon the head. Tentacles of coral-red color without dots, their base brighter with gray tip."

This species occupies the region about Baracoa where several races are present, each with a rather restricted habitat. 
KEY TO THE SUBSPECIES OF CHONDROPOMA (CHONDROPOMISCA) UNILABIATUM Sculpture strong.

Outer lip with a deep orange axial zone within.

Shell pale orange unilabiatum

Shell deep orange rubrum

Outer lip without a deep orange axial zone within dunkeri Sculpture not strong obsoletum

\section{CHONDROPOMA (CHONDROPOMISCA) UNILABIATUM UNILABIATUM (Gundlach) Pfeiffer}

Plate 39, Figure 3

1860. Cyclostoma (Chondropoma) unilabiatum (Gundlach) PFeIfFer, Malakozool. Blätter, vol. 7 , p. 31.

This race comes from the Fort at El Paraiso, Baracoa. It is smaller and paler red than $C$. $(C$.) unilabiatum mibrum and also has the red axial zone of the inside of the outer lip paler and less extensive.

The specimen figured, U.S.N.M. no. 354940 , is one collected by Gundlach. It has 4 whorls remaining and measures: Length, 9.5 $\mathrm{mm}$; greater diameter, $6.3 \mathrm{~mm}$; lesser diameter, $5.2 \mathrm{~mm}$.

CHONDROPOMA (CHONDROPOMISCA) UNILABIATUM RUBRUM, new subspecies

Plate 39, Figure 1

This race comes from the east side of Baracoa Harbor. It is distinguished from typical $C$. $(C$.) unilabiatum by its larger size and much more intensely red coloration of both shell and interior of outer lip.

The type, U.S.N.M. no. 468967 , has 4.5 whorls remaining and measures: Length, $11.4 \mathrm{~mm}$; greater diameter, $7.8 \mathrm{~mm}$; lesser diameter, $6.0 \mathrm{~mm}$.

CHONDROPOMA (CHONDROPOMISCA) UNILABIATUM OBSOLETUM, new subspecies

\section{Plate 39, Figure 7}

1860. Cyclostoma (Chondropoma) unilabiatum $\beta$ (GUNdLACH) PFeIfFer, Malakozool. Blätter, vol. 7, p. 31.

This subspecies comes from Mata, east of Baracoa. Here the color varies from white to yellow to pale orange, while the axial and spiral sculpture in both are decidedly reduced.

The type, U.S.N.M. no. 354941, has 4 whorls remaining and measures: Length, $10.2 \mathrm{~mm}$; greater diameter, $6.5 \mathrm{~mm}$; lesser diameter, $5.3 \mathrm{~mm}$. 
CHONDROPOMA (CHONDROPOMISCA) UNILABIATUM DUNKERI (Arango) Pfeiffer

Plate 39, Figure 4

1866. Chondropoma dunkeri (ARAngo) Pfeiffer, Malakozool. Blätter, vol. 13, p. 63.

This subspecies comes from Cayojuin near Baracoa. Here the outer lip lacks the axial orange band within the aperture; the spiral sculpture is also a little stronger than in the other races.

The specimen described and figured, U.S.N.M. no. 354939, a topotype, collected by Arango at Cayojuin, has 4 whorls remaining and measures: Length, $9.5 \mathrm{~mm}$; greater diameter, $6.3 \mathrm{~mm}$; lesser diameter, $5.2 \mathrm{~mm}$.

\section{CHONDROPOMA (CHONDROPOMISCA) SOLIDULUM (Gundlach) Pfeiffer}

Shell small, when truncated ovate, of flesh-colored or pale yellow ground color, marked with rather distantly spaced dots of brown, which form interrupted spiral bands and axial zones, for the dots are arranged in both spiral and axial series. Nuclear whorls 2, smooth, well rounded, forming a somewhat truncated apex. Postnuclear whorls narrowly shouldered at the summit, the early ones marked by slender axial riblets, which are retractively slanting and feeble spiral threads. On the succeeding whorls the spiral threads gain in strength until they equal or even excel the axial riblets and form at their junction with the axial riblets conspicuous oval nodules, which have their long axis parallel with the axial sculpture. The axial ribs on the major portion of the turns are not quite so wide as the spaces that separate them and they rather conspicuousiy crenulate the channeled suture. Periphery well rounded; base short, moderately openly umbilicated, and marked by the continuation of the axial ribs and spiral cords equaling those on the spire. The umbilical wall is also marked by spiral cords and the continuation of the axial ribs. Aperture broadly oval; peristome double, the outer and inner fused at the edge except on the parietal wall and the posterior angle of the aperture where they show distinctness. The peristome is slightly expanded on the outer lip and adnate to the preceding turn on the parietal wall. Operculum paucispiral, with the outside covered with a thin deposit of calcareous granules.

Of this species Gundlach says: "On the seashore at Baracoa, under rocks and dried leaves of Cocoloba. Animal whitish with white dots which are fused on the side into spots, and other dots of black on the neck, head and snout. Head reddish within. Tentacles with their base rose-red, turning gray toward the tip which is thickened and quite dark."

This species ranges from Baracoa westward along the coast through Sagua de Tanamo to Vita, breaking up into several subspecies. 
KEY TO THE SUBSPECIES OF CHONDROPOMA (CHONDROPOMISCA) SOLIDULUM

Ground color of shell flesh-color vitaense Ground color of shell yellow.

Length of decollated shell more than $10 \mathrm{~mm}$ solidulum

Length of decollated shell less than $9 \mathrm{~mm}$ tanamense

CHONDROPOMA (CHONDROPOMISCA) SOLIDULUM VITAENSE, new subspecies

\section{Plate 39, Figure 6}

This race comes from Vita Harbor. It is a pale race, in which the ground color is flesh-color, which renders the interrupted spiral markings all the more conspicuous. It is also larger than the other two races.

The type, U.S.N.M. no. 468968, comes from the west side of Vita Harbor. It has 3.3 whorls remaining and measures: Length, 11.6 $\mathrm{mm}$; greater diameter, $7.3 \mathrm{~mm}$; lesser diameter, $6.8 \mathrm{~mm}$.

CHONDROPOMA (CHONDROPOMISCA) SOLIDULUM SOLIDULUM (Gundlach) Pfeiffer Plate 39, Figure 9

1860. Cyclostoma (Chondropoma) solidulum (Gundeach) Pfeiffer, Malakozool. Blätter, vol. 7, p. 30 .

The typical race comes from Baracoa. We also have it from Cayojuin west of Baracoa.

This race closely resembles that of $C$. $(C$.) solidulum tanamense, from which it is differentiated by its uniformly larger size.

The type, U.S.N.M. no. 493116, has a little more than 4 whorls remaining and measures: Length, $10.4 \mathrm{~mm}$; greater diameter, 5.8 $\mathrm{mm}$; lesser diameter, $5.2 \mathrm{~mm}$.

CHONDROPOMA (CHONDROPOMISCA) SOLIDULUM TANAMENSE, new subspecies

Plate 39, Figure 5

1920. Chondropoma (Chondropoma) solidulum tanamensis (TORRE) HENDERson and Bartsch, Proc. U. S. Nat. Mus., vol. 58, p. 62 (nomen nudum).

This race comes from Sagua de Tanamo. It resembles the typical race in every way except in being much smaller.

The type, U.S.N.M. no. 493122, has 3.5 whorls remaining and measures: Length, $8.8 \mathrm{~mm}$; greater diameter, $6.3 \mathrm{~mm}$; lesser diameter $5.5 \mathrm{~mm}$.

\section{CHONDROPOMA (CHONDROPOMISCA) REVOCATUM (Gundlach) Pfeiffer}

Plate 39, Figure 10

1857. Cyclostoma revocatum (Gundlach) PFEIFfer, Malakozool. Blätter, vol. 4, p. 178.

1858. Chondropoma revocatum (Gundlach) PfEJfFer, Malakozool. Blätter, vol. 5, p. 191. 
Shell moderately large, when truncated almost subglobose, pale orange-red. Nuclear whorls almost 2, inflated, strongly rounded, the initial portion chestnut-brown, without sculpture. Postnuclear whorls very strongly inflated, strongly rounded, narrowly shouldered at the summit, unicolor, marked by numerous slender retractively curved axial riblets, which are only about one-fourth as wide as the spaces that separate them and spiral cords of about the same strength and spacing. The junctions of these two elements form minute cusps, while the spaces enclosed between them are rectangular pits having their long axis parallel with the axial sculpture. Periphery inflated, strongly rounded. Base inflated, strongly rounded, moderately openly umbilicated and marked like the spire. This sculpture also extends onto the umbilical wall, but here the axial riblets become very closely approximated. The last whorl is solute for a short fraction of a turn. Aperture very broadly ovate; peristome double, the inner exserted and reflected quite distinct from the outer; the outer moderately broad, obliquely expanded and marked by feebly concentric lamina, rendered crenulated by the external sculpture. On the parietal wall, however, the outer peristome is much narrower than on the rest of the turns. Operculum thin, paucispiral, with subcentral nucleus and a fine granular deposit on the outside.

Of the animal of this species Gundlach ${ }^{13}$ says: "Below rocks and dry leaves in shrubbery. The animal is light in color, dotted with fine white dots, the snout and forehead are marked by minute dark dots and is transversely sharply delineated. There are also some fine dots between the antennae, which are cinnabar red with somewhat brownish tips. The head is reddish within, but the head itself, as well as the base of the tentacles, are white. The digestive system is visible through the substance of the animal."

The specimen figured, U.S.N.M. no. 493125, is a cotype collected by Gundlach at the Estero en Cabo Cruz. It has 3.5 whorls remaining and measures: Length, $11.8 \mathrm{~mm}$; greater diameter, $8.7 \mathrm{~mm}$; lesser diameter, $7.2 \mathrm{~mm}$.

\section{CHONDROPOMA (CHONDROPOMISCA) GREENFIELDI, new species}

\section{Plate 39, Figure 8}

Shell rather large, when truncated subglobular, flesh-color, with interrupted spiral bands of brown, the dots composing which are also arranged in axial series. Nuclear whorls 2.3, inflated, strongly rounded, finely granulose, the initial portion dark chestnut brown. Postnuclear whorls very strongly inflated, rounded, very narrowly shouldered at the summit, forming a slightly channeled suture, 
marked by rather distantly spaced, moderately strong, retractively slanting axial riblets, and much stronger distantly spaced spiral cords, which on the last turn show intercalated cords of a finer strength than the major cords. Periphery inflated, strongly rounded. Base inflated, openly moderately broadly umbilicated, strongly rounded and marked like the spire, with spiral cords of similar strength and a continuation of the axial riblets. On the umbilical wall the axial riblets become slenderer, more lamellose and more closely approxi mated, while the spiral sculpture becomes decidedly reduced. The last whorl is solute for a slight fraction of a turn. Aperture broadly oval; peristome double, the inner decidedly exserted and slightly reflected; the outer obliquely expanded, narrower on the parietal wall than on the rest, marked by slender concentric laminae and forming somewhat of an auricle at the posterior angle. Operculum thin, paucispiral, with almost submarginal nucleus.

The type, U.S.N.M. no. 390425, was collected by Bartsch at the mouth of the Rio Ojo del Toro, Oriente, Cuba. It has 4 whorls remaining and measures: Length, $14.2 \mathrm{~mm}$; greater diameter, $11.0 \mathrm{~mm}$; lesser diameter, $8.2 \mathrm{~mm}$.

The large series of specimens before us from this locality and the mouth of the Rio Puerco, a nearby stream, shows this to be a perfectly distinct species, which in many ways recalls $C$. $(C$.) revocatum, but its larger size and much coarser sculpture apparently without intergrades entitle it to specific rank.

Of the animal of this species Bartsch's field notes, taken at Rio Puerco, August 30, 1930, state: "Forehead very pale pinkish brown, tentacles smoke gray, moderately long slender ovally expanded at the tip. Snout pale buff with a smoky tinge. Side of the body pale smoky gray. Sole of the foot short, medially cleft, wave motion of the two sides alternate. Progression is by short jerks, the shell being carried obliquely."

Found under stones, quite abundant.

CHONDROPOMA (CHONDROPOMISCA) AGUAYOI, new species

Plate 35, Figure 9

Shell elongate-ovate, pale straw-color, with the first portion of the remaining whorls chestnut-brown, which is also the color of the line marking the plug in the truncated end. There are also present very weak, rather distantly spaced, interrupted lines of brown. Nuclear whorls decollated in all our specimens; postnuclear whorls moderately rounded, narrowly shouldered at the summit and marked by slender, retractively curved, somewhat sinuous, axial riblets and spiral threads of the same strength, the combination of the two producing 
fine, low, rounded nodules at their intersection. The axial riblets are slightly closer spaced than the spiral threads. Of the spiral threads, 16 occur between the periphery and the summit on the last turn. Periphery well rounded; base moderately long, strongly rounded and marked by the continuation of the axial riblets which extend into the umbilicus, and 14 spiral threads of about the same strength as those on the spire. The umbilicus is rather wide, and in addition to the axial riblets shows strong spiral threads. Aperture ovate; peristome double, white, the outer narrowly expanded, forming a conspicuous pointed auricle at the posterior angle, the inner also expanded and appressed to and adnate to the outer, conspicuously separated only at the auricle. Operculum thin, paucispiral, corneous.

The type, U.S.N.M. no. 493291, was collected by John B. Henderson at Santa Lucia, La Silla, Oriente. It has 4.4 whorls remaining and measures: Length, $15.3 \mathrm{~mm}$; greater diameter, $9.0 \mathrm{~mm}$; lesser diameter, $7.4 \mathrm{~mm}$.

This species can readily be distinguished from the other members of Chondropoma (Chondropomisca) by its much more elongated form.

\section{Subgenus Chondropomartes Henderson and Bartsch}

1921. Chondropomartes Henderson and Bartsch, Proc. U. S. Nat. Mus., vol. 58 , p. 60.

Shell ovate-conic, the intersections of the axial ribs and spiral threads forming sharp cusps. Operculum with a very heavy callus.

This group, as set up by Henderson and Bartsch, was a heterogeneous assemblage. Additional material collected about Matanzas shows that $C$. $(C$.) presasianum, the type species, is connected with intergradient forms with $C$. $(C$.) irradians. While the hollow spines formed by the intersection of the axial ribs and spiral sculpture may be reduced to almost the vanishing point, they are, nevertheless, indicated in all the forms.

The present arrangement was made possible and easily intelligible by the accessions obtained by Dr. de la Torre and from his coworkers, which show that the subgenera as now conceived constitute a perfectly natural group. An interesting character is the very heavy callus on the operculum. The group, as now constituted, centers about Matanzas.

Type: Chondropoma presasianum (Gundlach) Pfeiffer.

KEY TO THE SPECIES OF SUBGENUS CHONDROPOMARTES

Spines very strong

Spines very fine irradians

Spines intermediate between the above portuandoi 


\section{CHONDROPOMA (CHONDROPOMARTES) PRESASIANUM (Gundlach) Pfeiffer}

Shell elongate-conic, flesh-color, with brownish markings that form axial and interrupted spiral elements. These bands of brown show up best on the expanded portion of the outer peristome, where they form alternate areas with the ground color. Postnuclear whorls well rounded, narrowly shouldered at the summit, marked by sublamellar, somewhat wavy, retractively slanting axial ribs and spiral cords; the junctions of the two form hollow tubercular spines, which, when the tip is broken away, prove to be made up of a mere thin shell of substance. The spaces enclosed between the spiral cords and the axial ribs are rectangular areas having their long axis parallel with the axial sculpture. Suture well constricted. Periphery inflated, strongly rounded. Base inflated, strongly rounded, openly umbilicated, and marked by the continuations of the axial riblets and spiral threads, which equal those on the spire. The umbilical wall is also similarly marked, but here the sculpture becomes somewhat reduced. Aperture oval, with a slight contraction at the posterior angle; peristome double, the inner forming a ring, which is slightly expanded, slightly reflected, smooth, and somewhat thickened, the outer forming a very broad, flaring, slightly up-curved expansion, which extends all around in equal width except where it touches the preceding turn at the parietal wall, where it is very narrow. This flaring portion is marked by a series of wavy scalloped lamellae, which form a regular series of elevations and depressions from the inner peristome outward to the outer margin. These lamellae are very delicate and in many of the specimens examined have been lost, probably in the cleaning process. On the outside of this expanded portion the ridges forming the fimbriations prove to be extensions of the spiral cords, the areas between them being broader. Operculum thin, horny, paucispiral, with subcentral nucleus, the outside of all but the central whorls being covered with minute calcareous granules.

Bartsch's field notes, Station 20, Finca El Pan, July 21, 1928, state:

"Animal short, forehead marked with numerous short brownish streaks. This darkish area is bordered on each side by a flesh-colored zone, which is slightly tinged with smoke gray. This same color extends from this area over the tentacles, which are flesh-color, almost white, with a grayish tinge. The tentacles swell out slightly toward the tip and here are a little darker in color. Sides of the body smoke gray. Sole of foot a little paler than the sides, deeply medially cleft. Motion of the two sides alternate."

The animals, after being removed from the stones to which we found them cemented, would withdraw deeply within their shells and refuse to come out. Only one did so after a very long wait. In 
this respect it differs radically from Chondropoma (Chondropomartes) irradians, which is ever ready to move.

This species comes from El Palenque and the adjacent limestone blocks, and extends west to Canasi. We are recognizing two subspecies.

KEY TO THE SUBSPECIES OF CHONDROPOMA (CHONDROPOMARTES) PRESASIANUM Shell small, pale and slender. canasiense Shell moderately larger, darker, and stouter presasianum

CHONDROPOMA (CHONDROPOMARTES) PRESASIANUM CANASIENSE, new subspecies

Plate 37, Figure 5

This race comes from near Canasi, west of Matanzas. It is smaller, slenderer, and paler than $C$. $(C$.) presasianum presasianum.

The type, U.S.N.M. no. 367754, was collected by Arango. It has 4.8 whorls remaining and measures: Length, $14.4 \mathrm{~mm}$; greater diameter, $10.0 \mathrm{~mm}$; lesser diameter, $7.0 \mathrm{~mm}$. CHONDROPOMA (CHONDROPOMARTES) PRESASIANUM PRESASIANUM (Gundlach)

\section{Plate 37, Figure 4}

1863. Chondropoma presasianum (Gundlach) PfEIfFER, Malakozool. Blätter, vol. 10 , p. 188.

This, the typical race, occupies the main range of El Palenque as well as some of the limestone blocks that have become separated from it by erosion. It is larger, stouter, and darker than $C$. $(C$.) presasianum canasiense.

The specimen figured, U.S.N.M. no. 499603, comes from the Elena Farm, El Palenque. It has 5.2 whorls remaining and measures: Length, $18.0 \mathrm{~mm}$; greater diameter, $12.8 \mathrm{~mm}$; lesser diameter, 7.5 $\mathrm{mm}$.

CHONDROPOMA (CHONDROPOMARTES) PORTUANDOI, new species

\section{Plate 37, Figure 3}

Shell elongate-conic, early whorls dark, the rest pale yellow with broad interrupted spiral bands of brown; peristome is very darkly and conspicuously rayed. Nuclear whorls 2.2, decidedly inflated and strongly rounded, forming a blunt apex. Postnuclear whorls marked by slender, slightly retractively curved axial and spiral threads, the latter a little stronger than the axial; the junction of the two forms low feeble hollow spines. Suture moderately constricted. Periphery inflated, well rounded. Base short, inflated, strongly rounded, openly umbilicated, and marked by the continua$66879-38-13$ 
tion of the axial riblets and spiral threads, those on the posterior half of the base being finely spinose and those on the anterior half and within the umbilicus finely scalloped. Aperture broadly oval; peristome double, the outer very broadly expanded, fluted and marked with closely spaced lamellae; inner peristome slightly exserted and reflected, appressed to the outer. Operculum thin, paucispiral, with submarginal nucleus covered by a granular calcareous deposit.

The type, U.S.N.M. no. 567755, has a little more than 4 whorls remaining and measures: Length, $16.8 \mathrm{~mm}$; greater diameter, 12.2 $\mathrm{mm}$; lesser diameter, $7.5 \mathrm{~mm}$.

This species, like $C .(C$. $)$ irradians, is lively and readily comes from the shell when it is permitted to remain quiet for a little while.

This species was collected by Portuando and later by Bartsch on two small limestone blocks lying off the north side of El Palenque near the house of Desidero Sanchez.

This species has the combined characteristics of $C$. $(C$.$) presasia-$ num and $C$. $(C$.) irradians. It is possible that it may represent a hybridization of the two. However, all of our specimens are so uniform in their characters that if hybridization is their source then fixation has taken place.

\section{CHONDROPOMA (CHONDROPOMARTES) IRRADIANS (Shuttleworth) Pfeiffer}

Shell elongate-conic, varying in ground color from white to pale horn-color to pale brown. The postnuclear whorls are marked with interrupted spiral bands of brown of varying width, which are also arranged in axial series, the bands on the spire being a little broader than those on the base. Interior of aperture of the same color as the outside. Peristome white, with broad brown rays. There is an oblique brownish band marking the plug at the truncated end. Nuclear whorls 2.3 , strongly rounded, smooth with a few incremental lines at the termination of the nuclear spire; the whorls remaining well rounded, narrowly shouldered at the summit, marked by feeble, retractively slanting, moderately closely spaced axial and spiral threads, the latter a little stronger than the axial. The junctions of these two elements form feeble nodules, while the spaces enclosed between them are more or less squarish pits. The spiral threads near the summit show more of a tendency toward nodulation than those on the middle of the turns. Periphery of the last turn well rounded. Base short, well rounded, marked by the continuation of the feeble axial and spiral threads. The latter are here of about the same strength as those on the spire, but rendered a little more strongly nodulose by the axial threads than on the spire. The base 
is openly umbilicated. The outside of the umbilical wall is marked by the continuation of the axial riblets and spiral threads. Aperture moderately large, ovate; peristome double, the outer very broadly, flaringly expanded, not quite in one plane but somewhat wavy, of about the same width all around except at the parietal wall where it is much narrower and where it is appressed and adnate to the preceding turn. The expanded outer peristome is composed of a series of concentric lamellae. The inner peristome is a little thicker, moderately elevated, slightly expanded and reflected. Operculum thin, corneous, paucispiral, with the nucleus almost submarginal, the outside covered with a deposit of fine calcareous granules, which are placed in a more or less wavy pattern.

Of the animal of $C$. $(C$.) irradians palenquense Bartsch took the following field notes at El Palenque, July 21, 1928, Station 19:

"Animal short, with numerous small elongate spots of brown on the forehead, which give to the back a somewhat brownish appearance. Base of tentacles with a whitish buffy ring bordered on the sides by a streak of the same color. Tentacles ashy gray, muzzle light ashy buff. Sides of the body buffish gray. Sides of foot ashy; sole of foot ashy with a faint yellowish tinge, deeply medially cleft. Motion of the two sides alternate."

In this species the animal readily comes out of the shell if it is allowed to remain quiet for a little while. In this respect it differs radically from $C$. $(C$.) presasianum, which refuses to come forth readily.

This species ranges from Loma Quintinal through Vista Alegre, through Abra Figueroa, through Pan de Matanzas, through El Palenque, and through the Sierra Camarones to Vieja Beremeja.

We are recognizing six subspecies.

Distribution of the subspecies of $C .(C$.$) irradians is shown in$ figure 101.

\section{KEY TO THE SUBSPECIES OF CHONDROPOMA (CHONDROPOMARTES) IRRADIANS}

Ground color pale brown.

Shell large panense

Shell not large.

Shell brilliantly banded figuroense

Shell not brilliantly banded irradians Ground color not pale brown.

Ground color flesh-color.

Decollated shell more than $17 \mathrm{~mm}$

Decollated shell less than $15 \mathrm{~mm}$ Ground color not flesh-color, but white. candicans 
CHONDROPOMA (CHONDROPOMARTES) IRRADIANS IRRADIANS (Shuttleworth) Pfeiffer

\section{Plate 37, Figure 1}

1852. Chondropoma irradians (Shuttleworth) Pfeiffer, Catalogue of Phaneropneumona ... in the British Museum, p. 209.

1854. Chondropoma irradians PFeIffer, Martini-Chemnitz Conchylien Cabinet, vol. 1 , sect. 19 , p. 273 , pl. 37 , figs. 9-10.

The typical form of this species was collected by Rugel at Loma Quintinal, near Matanzas, and by him sent to Shuttleworth, who in turn sent a letter to Pfeiffer, who published Shuttleworth's description as cited above. We have four specimens also collected by Rugel, one of which we figure, which indicate plainly that this is the small dark race which extends from Quintinal southwestward through the limestone block terminating at Vista Alegre.

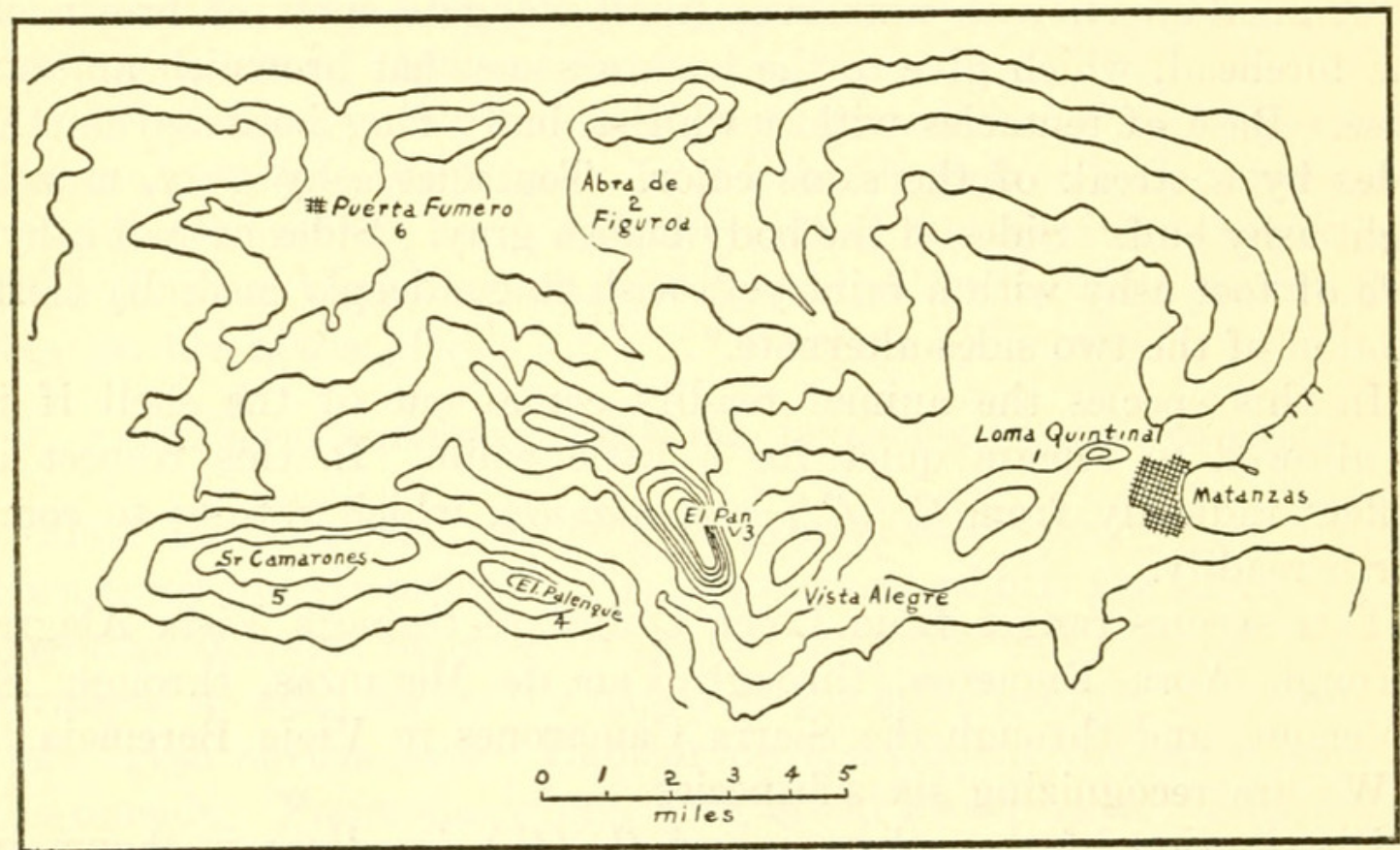

Figure 101.-Distribution of the subspecies of Chondropoma (Chondropomartes) irradians:

(1) irradians; (2) figuroense; (3) panense; (4) palenquense; (5) camaroneuse; (6) candicans,

The small size and dark color are its distinguishing features.

The specimen figured, U.S.N.M. no. 493126, has a little more than 5 whorls remaining and measures: Length, $13.8 \mathrm{~mm}$; greater diameter, $9.0 \mathrm{~mm}$; lesser diameter, $6.0 \mathrm{~mm}$.

CHONDROPOMA (CHONDROPOMARTES) IRRADIANS FIGUROENSE, new subspecies

\section{Plate 36, Figure 3}

This is the brilliantly colored race occupying the Abra de Figuroa. It is a little larger than the typical race and much more brightly colored. 
The type, U.S.N.M. no. 499606, one of a large series from the same place, is almost a complete specimen. It has 7 whorls remaining and measures: Length, $19.5 \mathrm{~mm}$; greater diameter, $12.0 \mathrm{~mm}$; lesser diameter, $6.8 \mathrm{~mm}$.

CHONDROPOMA (CHONDROPOMARTES) IRRADIANS PANENSE, new subspecies

Plate 36, Figure 4

This, the largest race collected by Presas, Gundlach, Wright, Torre, Henderson, Bartsch, and others on the south exposure of Pan de Mantanzas, is comparatively dull in color and less strongly sculptured than the rest.

The type, U.S.N.M. no. 493133, has 5 whorls remaining and measures: Length, $18.9 \mathrm{~mm}$; greater diameter, $13.8 \mathrm{~mm}$; lesser diameter, $8.1 \mathrm{~mm}$.

CHONDROPOMA (CHONDROPOMARTES) IRRADIANS PALENQUENSE, new subspecies

Plate 36, Figure 5

A large series of specimens from a number of stations on the north face of El Palenque, while agreeing fairly well in size with $C .(C$.) imradians figuroense, are paler in coloration and a little more strongly sculptured.

The type, U.S.N.M. no. 367756, has 4 and the basal half of the first of the remaining turns and measures: Length, $17.8 \mathrm{~mm}$; greater diameter, $12.2 \mathrm{~mm}$; lesser diameter, $7.2 \mathrm{~mm}$.

CHONDROPOMA (CHONDROPOMARTES) IRRADIANS CAMARONENSE, new subspecies

Plate 36 , Figure 2

This race, which comes from the Sierra de Camarones, is as small and as stout as $C$. (C.) irradians candicans but of buff instead of white ground color. The outer peristome is unusually broadly expanded.

The type, U.S.N.M. no. 499607, comes from a cliff about 500 meters west of Peña del Leon. It has about 4.5 whorls remaining and measures: Length, $15.4 \mathrm{~mm}$; greater diameter, $11.8 \mathrm{~mm}$; lesser diameter, $6.5 \mathrm{~mm}$.

CHONDROPOMA (CHONDROPOMARTES) IRRADIANS CANDICANS, new subspecies

Plate 36, Figure 1

This, the palest of all the known races, has the ground color white, which renders the interrupted spiral bands of brown quite contrasted. The sculpture is also a little finer than in the other subspecies. In size it agrees with $C .(C$.$) irradians camaronense.$ 
The type, U.S.N.M. no. 367757, comes from Potrero Fumero, Vieja Bermeja. It has 4 whorls remaining and measures: Length, 14.0 $\mathrm{mm}$; greater diameter, $10.8 \mathrm{~mm}$; lesser diameter, $7.4 \mathrm{~mm}$.

\section{Gutierrezium, new subgenus}

Shell turbinate. Nuclear whorls, 1.8, well rounded, microscopically granulose. Postnuclear whorls inflated, strongly rounded, and marked by slender axial ribs and spiral threads, which vary in strength from that equal to the axial ribs to almost obsolete in different species. The junctions of the axial and spiral sculpture form pronounced tubercles. On the last whorl the sculpture usually becomes almost obsolete. Periphery strongly rounded. Base inflated, strongly rounded, and marked by the continuation of the fine axial riblets and spiral threads a little stronger than those on the spire of the last turn. These form cords in the rather widely open umbilicus. Aperture broadly ovate; peristome double, the outer very broadly expanded excepting on the parietal wall where it is narrower; the inner slightly projecting and reflected partly over the outer. Operculum thin, corneous, paucispiral with subcentral nucleus.

Type: Chondropoma (Gutierrezium) bairense, new species.

This subgenus is closely allied to Chondropomella Bartsch of Santo Domingo, which is typified by Chondropoma (Chondropomella) magnifica (Sallé) Pfeiffer. Here, however, we have the spiral sculpture extending upon the whorls between the periphery and summit of the turns, which is not the case in Chondropomella. In some of the species this sculpture is quite reduced and requires to be looked for sharply not to be overlooked.

\section{KEY TO THE SPECIES OF SUBGENUS GUTIERREZIUM}

Suture channeled.

Spiral sculpture strong bairense

Spiral sculpture feeble canaliculatum Suture not channeled.

Axial ribs closely spaced.

Outer peristome very broadly expanded montanum

Outer peristome only moderately expanded. guisaense Axial ribs distantly spaced. gutierrezi

\section{CHONDROPOMA (GUTIERREZIUM) BAIRENSE, new species}

Plate 38, Figure 2

Shell broadly ovate, turbinate; the early whorls chestnut-brown, the succeeding turns flesh-color, marked by almost conspicuous interrupted spiral bands of brown, of which four are present on the spire and four on the base. They also mark the outer peristome and the 
inside of the outer lip. Nuclear whorls decollated; postnuclear whorls very strongly inflated and very strongly rounded, marked by closely spaced, retractively slanting axial riblets and spiral threads of about the same strength. Both of these are much stronger on the early whorls than on the last. The combination of these two elements gives a fenestrated pattern to the sculpture. The axial riblets render the summit of the turns feebly denticulated. Suture strongly constricted. Periphery decidedly inflated, strongly rounded. Base short, inflated, strongly rounded and marked on the posterior half like the spire, while anteriorly it bears a number of strong spiral cords. Umbilicus very broad, its wall marked with slender spiral threads which become a little stronger toward the outer margin. Aperture broadly oval; peristome double, the outer flaringly expanded, forming a very conspicuous auricle at the posterior angle a little narrower on the parietal wall. Inner peristome also expanded and reflected over the outer, which it almost half covers. Operculum thin, corneous, paucispiral with subcentral nucleus, the outside covered with a thin layer of calcareous granules.

The type, U.S.N.M. no. 367817, was collected by Dr. de la Torre near Baire. It has 4 whorls remaining and measures: Length, 16.2 $\mathrm{mm}$; greater diameter, $13.2 \mathrm{~mm}$; lesser diameter, $10.4 \mathrm{~mm}$.

This, the type of the subgenus Gutierrezium, is easily differentiated from all the other forms of this subgenus by its strong spiral sculpture.

\section{CHONDROPOMA (GUTIERREZIUM) CANALICULATUM, new species}

\section{Plate 38, Figure 5}

Shell very broadly ovate, the early whorls chestnut-brown, the succeeding turns yellowish flesh-color, the last one flesh-color, marked with interrupted spiral bands of chestnut-brown, which are arranged also in axial series. Four of these bands occur on the spire and three on the base. These are very conspicuous on the outer and basal lip, as well as on the outer peristome. Nuclear whorls 1.8, strongly rounded, marked with miscroscopic granulations only. Postnuclear whorls inflated, strongly rounded, marked by decidedly retractively slanting axial riblets, which serrulate the margin of the channeled suture. These riblets are a little more distantly spaced on the early turns than on the last. In addition to this, the whorls are marked by feeble spiral threads, too feeble to more than merely render the axial riblets vertebrated at their junction. Suture strongly constricted; periphery inflated, strongly rounded. Base short, inflated, strongly rounded, very openly umbilicate, and marked like the spire but with the spiral lirations a little stronger. The umbilical wall, however, is marked by very strong spiral threads. Aperture broadly ovate, decidedly auriculated at the posterior angle. Peristome double, the 
outer broadly expanded, not all in one plane, and somewhat flexuose, decidedly auriculated at the posterior angle and slightly inbent at the umbilicus, a little narrower on the parietal wall than on the rest of the shell. Inner peristome slightly exserted and reflected over the outer. Operculum thin, corneous, paucispiral, the nucleus halfway between margin and subcentral covered with a thin deposit of calcareous granules on the outside.

The type, U.S.N.M. no. 168902, an almost complete specimen, has 5.5 whorls remaining and measures: Length, $16.0 \mathrm{~mm}$; greater diameter, $12.3 \mathrm{~mm}$; lesser diameter, $8.9 \mathrm{~mm}$. It was collected by $\mathrm{Dr}$. Vaughan at Los Negros, Oriente Province.

This species is readily distinguished from the other members of the genus by its decidedly channeled suture.

\section{CHONDROPOMA (GUTIERREZIUM) MONTANUM, new species}

\section{Plate 37, Figure 2}

Shell broadly ovate, pale buff, marked by interrupted spiral bands of brown, of which three occur on the whorls of the spire and three on the base. These bands become conspicuous on the last portion of the last whorl and lend to the inside of the outer lip and the expanded peristome a very strongly banded aspect. Here an intercalated zone appears between the first basal and second, making seven bands on the peristome. The elements composing the interrupted spiral bands are arranged in both axial and spiral series. Nuclear whorls 2.1, well rounded, smooth. Postnuclear whorls strongly inflated, well rounded, marked by slender, decidedly retractively slanting, axial riblets, which are a little more widely spaced on the first. two turns than on those succeeding. On the last whorl they are considerably reduced. The spiral sculpture consists of the merest suggestion of obsolete threads. Suture very strongly constricted with the merest indication of channeling immediately behind the aperture. Periphery inflated, strongly rounded. Base short, inflated, open umbilicated. and marked by the continuation of the axial riblets and indications of spiral threads. Within the umbilicus, however, stronger definite spiral threads are present. Aperture broadly oval, almost subcircular, decidedly auriculated at the posterior angle. Peristome double, the outer very broadly expanded and reflected, narrower on the parietal wall than on the rest, marked by slender concentric laminae. The inner slightly exserted and reflected over the outer. Operculum thin, corneous, paucispiral with subcentral nucleus, the outside covered with fine calcareous granules.

The type, U.S.N.M. no. 367815, is a complete specimen, having 6.5 whorls and measuring: Length, $16.0 \mathrm{~mm}$; greater diameter, $10.4 \mathrm{~mm}$; 
lesser diameter, $8.0 \mathrm{~mm}$. It comes from Altos de los Negros, Sierra Maestra, Oriente Province.

This species resembles $C$. $(G$.$) guisuense in its general shape and$ sculpture but is at once distinguished by its very broadly expanded outer peristome.

\section{CHONDROPOMA (GUTIERREZIUM) GUISAENSE, new species}

\section{Plate 38, Figure 1}

Shell very broadly ovate, flesh-colored, with interrupted bands of brown; the elements composing these are arranged in both axial and spiral series. Nuclear whorls decollated. Postnuclear whorls inflated, strongly rounded, narrowly shouldered at the summit, marked by slender, somewhat retractively slanting axial riblets, which are more distantly spaced on the early whorls than on the last. On this they form serrulations at the summit. The spiral sculpture consists of the merest indications of basal threads. Suture strongly impressed, slightly channeled for one-third of a turn behind the aperture. Periphery inflated, strongly rounded and marked like the spire. Base short, inflated, strongly rounded and marked by the continuation of the axial riblets. The broadly open umbilicus shows fairly strong spiral cords on the umbilical wall. Aperture broadly ovate, slightly auriculated at the posterior angle; peristome double, the outer moderately broadly expanded; the inner also expanded a little more than half as wide as the outer and reflected over and appressed to it, projecting but slightly above it. Peristome a little narrower on the parietal wall than on the rest of the aperture, separated in the unique type from the preceding whorl.

The type, U.S.N.M. no. 367816, was collected by Dr. de la Torre at the hill nearest to Guisa, southeast of Bayamo. It has 3.8 whorls remaining and measures: Length, $17.0 \mathrm{~mm}$; greater diameter, 12.5 $\mathrm{mm}$; lesser diameter, $9.8 \mathrm{~mm}$.

This species in type of sculpture resembles $C .(G$.$) montanum$ but is at once distinguished from this by its much narrower outer peristome.

\section{CHONDROPOMA (GUTIERREZIUM) GUTIERREZI (Gundlach)}

Shell ovoid-conic, flesh-color or pale horn-color, with interrupted lines of brown arranged so as to form both axial and spiral series. Nuclear whorls 1.8, well rounded, minutely granulose. Postnuclear whorls well rounded, narrowly shouldered at the summit, with a short channel in the suture immediately behind the summit on the last turn. The whorls are marked by rather strong sublamellar, narrow, somewhat sinuous, irregularly developed, and irregularly 
distributed axial riblets, which extend prominently to the summit where they become somewhat expanded and occasionally somewhat thickened. These riblets extend prominently over the inflated and well-rounded periphery to the base. The spiral sculpture consists of obsolete indications of threads, which render the axial ribs slightly vertebrated. Base short, inflated, strongly rounded, broadly openly umbilicated, marked by the continuations of the axial ribs, which extend undiminished into the umbilicus, and obsolete indications of spiral threads like those of the spire. The umbilical wall is marked by strong spiral cords, which diminish in strength from the outside inward. Aperture pear-shaped. Posterior angle obtuse. Peristome decidedly expanded and obliquely reflected, not flattened; the outer lip is marked by dark spiral zones alternating with a broader white band; the parietal wall of the peristome is less broadly expanded than the rest. Operculum paucispiral with excentric nucleus, the last whorl with a thin calcareous granular deposit.

We are recognizing two subspecies.

KEY TO THE SUBSPECIES OF CHONDROPOMA (GUTIERREZIUM) GUTIERREZI

Decollated shell more than $17 \mathrm{~mm}$ Decollated shell less than $15 \mathrm{~mm}$ negrosense

\section{Chondropoma (GUtierreziUm) GUtierrezi GUTIERrezi (Gundlach) Pfeiffer}

\section{Plate 38, Figure 4}

1856. Cyclostoma gutierrezi (Gundlach) PoEY, Nemorias sobre historia natural de la Isìa de Cuba, vol. 2, p. 4, nomen nudum.

1858. Cyclostoma gutierrezi (Gundlach) PfeIfFer, Malakozool. Blätter, vol. 5, p. 46.

This race, which comes from the environs of Guisa, is distinguished from $C .(G$.$) gutierrezi negrosense in being much larger and of paler$ coloration.

A specimen from the type locality, U.S.N.M. no. 104507, collected by Gundlach, has 4.1 whorls remaining and measures: Length, 18.0 $\mathrm{mm}$; greater diameter, $13.7 \mathrm{~mm}$; lesser diameter, $10.0 \mathrm{~mm}$.

CHONDROPOMA (GUTIERREZIUM) GUTIERREZI NEGROSENSE, new subspecies

Plate 38, Figure 3

This race was collected by Dr. de la Torre at Los Negros southeast of Baire. It is much smaller and darker colored than the typical $C$. (G.) gutierreai gutierrezi.

The type, U.S.N.M. no. 367829, has 3.8 whorls remaining and measures: Length, $14.2 \mathrm{~mm}$; greater diameter, $10.5 \mathrm{~mm}$; lesser diameter, $8.0 \mathrm{~mm}$. 


\section{Genus CHONDROTHYRIUM Henderson and Bartsch}

1920. Chondrothyrium Henderson and Bartsch, Proc. U. S. Nat. Mus., vol. 58, p. 63.

Shell of ovate-conic form, marked by axial and spiral threads; breathing pore present in the parietal wall, connected with the outer edge of the peristome by a slit. Operculum typically chrondropomoid.

Type: Cyclostoma violaceum Pfeiffer.

\section{KEY TO THE SPECIES OF GENUS CHONDROTHYRIUM}

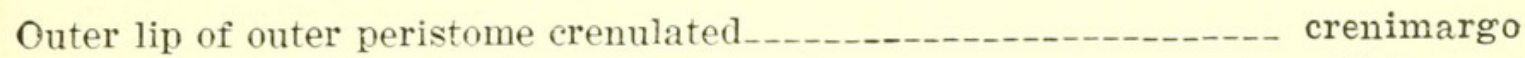
Outer lip of outer peristome not crenulated. violaceum

\section{CHONDROTHYRIUM CRENIMARGO (Pfeiffer)}

\section{Plate 28, Figure 16}

1858. Cyclostoma crenimargo PfeIffer, Malakozool. Blätter, vol. 5, p. 192.

Decollated shell elongate-ovate, flesh-color, with five interrupted narrow spiral lines of brown. Nuclear whorls decollated. Postnuclear whorls well rounded, almost appressed at the summit, marked by slender, sublamellose, wavy, retractively slanting axial riblets, which are a little more distantly spaced on the first of the remaining turns than on those that follow. These riblets extend prominently to the summit, which they render slightly crenulated. In addition to the axial riblets, the whorls are marked by spiral threads, of which 5 occur on the first of the remaining turns, 10 upon the second, and 13 upon the last between the summit and the suture. The intersections of the axial riblets and the spiral threads form slender oval nodules, the long axis of which coincides with the axial sculpture. Suture moderately constricted. Periphery well rounded, slightly inflated. Base short, somewhat inflated and rounded, narrowly openly umbilicated, marked by the continuations of the axial riblets, which extend into the umbilicus and also by the continuation of a similar type of spiral sculpture as that found on the spire. This grows a little stronger toward the umbilicus but again weakens within the umbilicus. There are eight of these spiral cords between the periphery and the outer termination of the umbilicus, then four equally strong between the outer termination of the umbilicus, and the inner straight side of the umbilicus, and about nine on the umbilical wall which are much weaker. On the base, too, we find seven lines of brownish dots coinciding with the spiral sculpture. Aperture oval, posterior angle obtuse; peristome double, the inner thickened and somewhat reflected, and decidedly projecting above the outer on the outer lip; the outer much broader and rendered decidedly wavy 
from the posterior angle to the termination of the outer lip, mostly so immediately anterior to the posterior angle. This waviness gives the edge, when looked upon vertically, a crenated appearance which evidently prompted Pfeiffer's name crenimargo. The basal, inner, and parietal margin of the outer peristome is composed of a series of slender fused laminae whose outer limits are indicated by a mere line; the outer peristome of the inner lip is broader than the rest and is reflected over the umbilicus which, when looked upon squarely, it almost covers; the outer peristome of the parietal lip is appressed to the preceding turn with which it is fused; the breathing pore is on the parietal wall near the posterior angle of the aperture, and here the parietal wall is partly slit; operculum paucispiral with the nucleus a little more marginal than subcentral; the outside is covered with a minutely granulose coat.

All our specimens come from the type locality, Boca de Guarabo, between Cienfuegos and Trinidad, Santa Clara Province.

The specimen described and figured, U.S.N.M. no. 355039 has 3.5 whorls remaining and measures: Length, $13.7 \mathrm{~mm}$; greater diameter, $7.5 \mathrm{~mm}$; lesser diameter, $7.0 \mathrm{~mm}$.

\section{CHONDROTHYRIUM VIOLACEUM (Pfeiffer)}

Shell rather variable in size and shape, the latter ranging from elongate-conic to broadly ovate. The color ranges from flesh-color through pale orange to purplish brown. The shell may be unicolor or have interrupted bands of brown. The dots comprising these bands are also arranged in axial series. Nuclear whorls 2.3, rather elevated, well rounded, smooth, with the suture of the first turn chestnut-brown. The last part of the last whorl shows the beginning of the postnuclear sculpture. Postnuclear whorls well rounded, almost appressed at the summit, marked by numerous slender, sublamellar, somewhat retractively slanting, axial riblets and slender spiral threads the junctions of which form slender tubercles. The spiral threads also render the axial riblets somewhat wavy and give to them, when examined in profile, a somewhat scalloped appearance. Suture constricted. Periphery well rounded. Base moderately long, well rounded, marked by the continuation of the axial riblets and spiral cords, the latter increasing in strength on the anterior half, but weakening again within the umbilicus which is moderately large and open. Aperture broadly oval, in some of the races almost subcircular; peristome double, white, the inner slightly thickened, expanded and slightly reflected, and projecting above the outer peristome, which is expanded to a varying degree in the different races on the outer, basal and parietal lip, and more broadly so on the columellar side; the outer peristome is usually not flat but somewhat wavy. The 
last whorl varies from solute to adnate. There is a breathing pore close to the posterior angle of the aperture on the parietal wall immediately behind the edge of the peristome, which is connected with the free edge of the peristome by a slit. Operculum thin, corneous, paucispiral, with a rather heavy deposit of calcareous granules on the outside.

This species is at present known from the south coast of Santa Clara Province, where it breaks up into a series of races on the various limestone blocks.

The animals of three of the subspecies were described by Bartsch as follows:

\section{Chondrothyrium violaceum violaceum}

Taken from a stone fence at La Pastora, 4 kilometers northwest of Trinidad.

Top of head buff, finely dotted with white; area about tentacles pale pink; tentacles coral red tipped with blue black; sides of body pale bluish smoky gray; sole of foot deeply cleft, a little paler than the sides of body.

\section{Chondrothyrium violaceum vigiaense}

Taken at La Vigia near Trinidad.

Top of head pale brown with a decided rosy flush; tentacles coralred tipped with dusky brown; area about the base of tentacles a little paler than general ground color; snout pale buff at tip; sides smoke gray marked by numerous papillae, which are marked by many fine white dots; sole of foot a little paler than sides of body, deeply cleft.

\section{Chondrothyrium violaceum leteranense}

Specimens taken at San Juan de Leteran.

Top of head buff with rosy flush; snout and sides of body with olivaceous ground color upon which numerous papillae, each marked with many white dots, are disposed; tentacles varying in different individuals from dark orange to carmine red, paler at base and dusky at tip, the latter very slightly expanded; sole of foot smoke gray. In moving, the animal may carry its shell steadily or it may move it by lateral jerks.

\section{KEY TO THE SUBSPECIES OF CHONDROTHYRIUM VIOLACEUM}

Interrupted spiral bands of brown very strong.

Truncated shell elongate-ovatemontanei

Truncated shell ovate.

Axial riblets very fine and closely spaced. mortei

Axial riblets not very fine and more widely spaced vigiaense 
Interrupted spiral bands of brown not strong.

Interrupted spiral bands of brown of medium strength.

Tubercles on last whorl very strong. clerchi

Tubercles on last whorl only moderately strong.

Tubercles of penultimate whorl very strong.

Decollated shell more than $17 \mathrm{~mm}$. leteranense

Decollated shell less than $14 \mathrm{~mm}$. fomentense

Tubercles of penultimate whorl not very strong.

Decollated shell elongate-ovate.

Decollated shell more than $18 \mathrm{~mm}$ violaceum

Decollated shell less than $15 \mathrm{~mm}$ tenue

Decollated shell ovate.

Spacing of axial ribs very regular manatiense

Spacing of axial ribs not very regular sopimpense

Interrupted spiral bands of brown feeble.

Tubercles rather coarse rocai

Tubercles not coarse maguasense

Interrupted spiral bands of brown not feeble.

Interrupted spiral bands of brown obsolete or absent.

Decollated shell elongate-ovate.

Decollated shell more than $20 \mathrm{~mm}$ long. banaoense

Decollated shell less than $15 \mathrm{~mm}$ long ignotum Decollated shell not elongate-ovate.

Decollated shell ovate.

Open umbilicus narrow.

Length of decollated shell more than $20 \mathrm{~mm}$ - gonzalesi Length of decollated shell less than $17 \mathrm{~mm}$.

Sculpture very fine atkinsi

Sculpture less fine serranum

Open umbilicus very wide.

Sculpture rough doloresi

Sculpture fine saugeti

\section{CHONDROTHYRIUM VIOLACEUM GONZALESI, new subspecies}

Plate 28, Figure 17

This race, which is probably the largest of the species, we have from Jagua Cienfuegos. The interrupted spiral bands are absent and the umbilicus is narrow; outer lip broadly expanded.

The type, U.S.N.M. no. 367820, has 4.2 whorls remaining and measures: Length, $20.6 \mathrm{~mm}$; greater diameter, $13.7 \mathrm{~mm}$; lesser diameter, $11.3 \mathrm{~mm}$.

\section{CHONDROTHYRIUM VIOLACEUM SERRANUM, new subspecies}

Plate 28, Figure 14

This race comes from Naranga Dulce, La Sierra, southeast of Cienfuegos. It resembles $C$. $v$. attinsi in the absence of interrupted spiral bands but has finer tuberculation and is smaller. 
The type, U.S.N.M. no. 367833, has 3.4 whorls remaining and measures: Length, $14.1 \mathrm{~mm}$; greater diameter, $10.1 \mathrm{~mm}$; lesser diameter, $8.0 \mathrm{~mm}$.

CHONDROTHYRIUM VIOLACEUM ATKINSI, new subspecies

Plate 28, Figure 15

This race comes from Soledad. It is a pale race of rather broadly ovate outline with comparatively narrow umbilicus, lacking the interrupted spiral bands. It is nearest to $C$. $v$. serranum, from which it can be readily distinguished by its more inflated whorls and finer tuberculation.

The type, U.S.N.M. no. 355048, has 4.3 whorls remaining and measures: Length, $19.4 \mathrm{~mm}$; greater diameter, $11.8 \mathrm{~mm}$; lesser diameter, $9.2 \mathrm{~mm}$.

CHONDROTHYRIUM VIOLACEUM DOLORESI, new subspecies

Plate 28, Figure 3

This race comes from between Guabairo and Dolores. It is of broadly ovate outline with widely open umbilicus, lacking the interrupted spiral bands of brown. It resembles $C$. violaceum saugeti but differs from this in having the shell heavier and the sculpture much coarser.

The type, U.S.N.M. no. 367826, has 3.5 whorls remaining and measures: Length, $12.0 \mathrm{~mm}$; greater diameter, $10.4 \mathrm{~mm}$; lesser diameter, $7.6 \mathrm{~mm}$.

\section{CHONDROTHYRIUM VIOLACEUM VIOLACEUM (Pfeiffer)}

Plate 28, Figure 19

1551. Cyclostoma violaceum Pfeiffer, Proc. Zool. Soc. London, 1851, pp. 245-246.

In this, the typical race, which we recognize in specimens from Trinidad and La Pastora, the shell is elongate-ovate, of yellowish buff color, with moderately strong interrupted spiral bands of brown. Here the tubercles on the penultimate whorl are not strong but correspond to those of the preceding turns.

The specimen described and figured, U.S.N.M. no. 104493, has 4.5 whorls remaining and measures: Length, $20.0 \mathrm{~mm}$; greater diameter, $12.1 \mathrm{~mm}$; lesser diameter, $9.7 \mathrm{~mm}$.

\section{CHONDROTHYRIUM VIOLACEUM MORTEI, new species}

Plate 28, Figure 4

This race, which was collected by Dr. de la Torre, comes from Nazimiento del Rio Caballero, near Trinidad. It has the whorls a 
little more inflated than $C$. violaceum vigiaense and the axial and spiral sculpture finer, more numerous and closer spaced. The dark spiral bands are also a little lighter.

The type, U.S.N.M. no. 367828 , has a little more than three whorls remaining, and measures: Length, $17.0 \mathrm{~mm}$; greater diameter, 11.7 $\mathrm{mm}$; lesser diameter, $9.7 \mathrm{~mm}$.

\section{CHONDROTHYRIUM VIOLACEUM VIGIAENSE, new subspecies}

Plate 28, Figure 1

This race comes from La Vigia near Trinidad. The truncated shell is of ovate outline and the coloration is very dark, tending to purplish on the last turn. The elements composing the broad interrupted spiral bands are arranged in axial series. The tips of the tubercles are white and stand out markedly against the dark background. The outer lip is also decidedly expanded on all sides. For comparison with $C$. violaceum montanei, see the diagnosis of that subspecies.

The type, U.S.N.M. no. 493282, has a little more than four whorls remaining and measures: Length, $18.8 \mathrm{~mm}$; greater diameter, 12.5 $\mathrm{mm}$; lesser diameter, $10.1 \mathrm{~mm}$.

\section{CHONDROTHYRIUM VIOLACEUM LETERANENSE, new species}

Plate 28, Figure 2

This race comes from San Juan de Leteran. Here the shell is elongate-conic and the tubercles on both the last and penultimate whorls are decidedly strong, in which respect it resembles $C$. violaceum fomentense, from which its larger size and more elongate form will readily distinguish it. The ground color is buff, and the interrupted spiral bands of brown are only of medium strength.

The type, U.S.N.M. no. 367832, has 5 whorls remaining and measures: Length, $17.8 \mathrm{~mm}$; greater diameter, $11.4 \mathrm{~mm}$; lesser diameter, $8.3 \mathrm{~mm}$.

\section{CHONDROTHYRIUM VIOLACEUM MAGUASENSE, new subspecies}

\section{Plate 28, Figure 7}

This race comes from the Magua Valley of Trinidad. It is a small pale race with feeble interrupted spiral bands of brown, in which respect it resembles $C$. violaceum rocai, from which it differs by its much finer tubercles and less inflated whorls.

The type, U.S.N.M. no. 367824, has 4 whorls remaining and measures: Length, $11.3 \mathrm{~mm}$; greater diameter, $7.8 \mathrm{~mm}$; lesser diameter, $6.2 \mathrm{~mm}$. 


\section{Plate 28, Figure 12}

This race comes from Loma del Marin, Rio Manati, Trinidad. It is a small race with the whorls decidedly inflated, of buff color, with the interrupted spiral bands of brown weakly developed but having their elements also in axial series. It resembles most closely $C$. violaceum sopimpense, from which it can be distinguished by its more inflated whorls and more regularly distributed axial ribs.

The type, U.S.N.M. no. 367821, has 4 whorls remaining and measures: Length, $14.6 \mathrm{~mm}$; greater diameter, $9.5 \mathrm{~mm}$; lesser diameter, $6.9 \mathrm{~mm}$.

CHONDROTHYRIUM VIOLACEUM SOPIMPENSE, new subspecies

\section{Plate 28, Figure 11}

This race comes from Sopimpa, which is on the railway between Fomento and Trinidad. Here the shell is also buff color, with a purplish flush. The interrupted spiral bands are moderately strong, the whorls are inflated, and the axial ribs are rather irregular in distribution, as well as in strength, a character that will readily distinguish it from $C$. violaceum manatiense.

The type, U.S.N.M. no. 355046 , has 4.2 whorls remaining and measures: Length, $13.7 \mathrm{~mm}$; greater diameter, $9.3 \mathrm{~mm}$; lesser diameter, $7.0 \mathrm{~mm}$.

\section{CHONDROTHYRIUM VIOLACEUM FOMENTENSE, new subspecies}

\section{Plate 28, Figure 8}

This small race comes from Fomento, northeast of Trinidad. Here the early whorls are decidedly darker than the last. The sculpture on the penultimate whorl is very heavy, in which respect it resembles $C$. violaceum leteranense, from which, however, it can readily be distinguished by its small size.

The type, U.S.N.M. no. 367822, has 4 whorls remaining and measures: Length, $13.5 \mathrm{~mm}$; greater diameter, $8.8 \mathrm{~mm}$; lesser diameter, $6.8 \mathrm{~mm}$.

\section{CHONDROTHYRIUM VIOLACEUM CLERCHI, new subspecies}

Plate 28, Figure 13

This subspecies was collected by Clerch at Quemado Feo. It is a small ovate race of flesh-colored ground color, with the interrupted spiral bands of brown only of medium strength. The axial riblets 
are rather distantly spaced, and the tubercles of the last whorl consequently have a decidedly strong aspect.

The type, U.S.N.M. no. 367827 , has a little more than 4 whorls remaining and measures: Length, $15.6 \mathrm{~mm}$; greater diameter, 11.0 $\mathrm{mm}$; lesser diameter, $8.4 \mathrm{~mm}$.

CHONDROTHYRIUM VIOLACEUM MONTANEI, new subspecies

Plate 28, Figure 20

This race was collected by Hermanos Leon and Roca at Rosa de Gavilanes in the Sierra de Cabillete. It is a large race of elongateovate outline, of yellowish buff ground color, with slender, wellmarked, interrupted spiral bands of brown whose elements are also arranged in axial series. In the strength of the color marking this race approximates $C$. violaceum vigiaense but is readily distinguished from this by its much more elongate form and much paler coloration.

The type, U.S.N.M. no. 367823, has 4 whorls remaining and measures: Length, $20.8 \mathrm{~mm}$; greater diameter, $12.9 \mathrm{~mm}$; lesser diameter, $10.5 \mathrm{~mm}$.

CHONDROTHYRIUM VIOLACEUM ROCAI, new subspecies

Plate 28, Figure 5

This race comes from the valley of the Rio Caracusey, Sancti Spiritus. It is a small race of ovate outline, having the interrupted spiral bands of brown very feeble, in which it agrees with $C$. violaceum maguasense, from which, however, its much more inflated whorls and coarser tubercles will readily distinguish it. The coloration is dark and the outer lip very strong.

The type, U.S.N.M. no. 367830, has 4.1 whorls remaining and measures: Length, $11.7 \mathrm{~mm}$; greater diameter, $8.2 \mathrm{~mm}$; lesser diameter, $6.5 \mathrm{~mm}$.

CHONDROTHYRIUM VIOLACEUM BANAOENSE, new subspecies

Plate 28, Figure 18

This large race comes from Banao southwest of Sancti Spiritus. It has fine axial riblets of elongate-ovate outline, with the interior brown and the lip white. It resembles $C$. violaceum ignotum but is at once distinguished from it by its large size and darker interior coloration.

The type, U.S.N.M. no. 367831, has 5 whorls remaining and measures: Length, $20.1 \mathrm{~mm}$; greater diameter, $14.1 \mathrm{~mm}$; lesser diameter, $10.7 \mathrm{~mm}$. 


\section{Plate 28, Figure 9}

This small race comes from Loma de Banao. Its shell is elongateovate, the early whorls being a little darker than the rest. Interrupted spiral bands only moderately strong. The sculpture of the penultimate whorl is no stronger than that of the preceding turn. The outer lip is also only moderately expanded. It differs from C. violaceum violaceum in being much smaller.

The type, U.S.N.M. no. 355050, has 4 whorls remaining and measures: Length, $14.7 \mathrm{~mm}$; greater diameter, $9.0 \mathrm{~mm}$; lesser diameter, $6.8 \mathrm{~mm}$.

\section{CHONDROTHYRIUM VIOLACEUM IGNOTUM, new subspecies}

\section{Plate 28, Figure 10}

With this race we have no definite locality. The shell is pale yellowish white, elongate-ovate, and the interrupted spiral bands are absent. It suggests $C$. violaceum banaoense but is very small in comparison.

The type, U.S.N.M. no. 315184, has 3.3 whorls remaining and measures: Length, $13.7 \mathrm{~mm}$; greater diameter, 9.2 ; lesser diameter, $7.0 \mathrm{~mm}$.

\section{CHONDROTHYRIUM VIOLACEUM SAUGETI, new subspecies}

\section{Plate 28, Figure 6}

This race comes from San José northeast of Sancte Spiritus. It is a thin-shelled, broadly ovate race, with very fine sculpture and with the outer lip poorly developed. It resembles most closely $C$. violaceum doloresi, from which its more ovate shell and finer sculpture will readily distinguish it.

The type, U.S.N.M. no. 367834, has 3.8 whorls remaining and measures: Length, $12.2 \mathrm{~mm}$; greater diameter, $9.8 \mathrm{~mm}$; lesser diameter, $7.0 \mathrm{~mm}$. 


\section{$2 \mathrm{BHL}$ Biodiversity Heritage Library}

Torre y Huerta, Carlos de la and Bartsch, Paul. 1938. "The Cuban operculate land shells of the subfamily Chondropominae." Proceedings of the United States National Museum 85(3039), 193-403. https://doi.org/10.5479/si.00963801.85-3039.193.

View This Item Online: $\underline{\text { https://www.biodiversitylibrary.org/item/32776 }}$

DOI: https://doi.org/10.5479/si.00963801.85-3039.193

Permalink: https://www.biodiversitylibrary.org/partpdf/29667

\section{Holding Institution}

Smithsonian Libraries

\section{Sponsored by}

Smithsonian

\section{Copyright \& Reuse}

Copyright Status: NOT_IN_COPYRIGHT

Rights: https://www.biodiversitylibrary.org/permissions/

This document was created from content at the Biodiversity Heritage Library, the world's largest open access digital library for biodiversity literature and archives. Visit BHL at https://www.biodiversitylibrary.org. 